\title{
Hydrology and Simulation of Ground-Water Flow in Cedar Valley, Iron County, Utah
}

Scientific Investigations Report 2005-5170

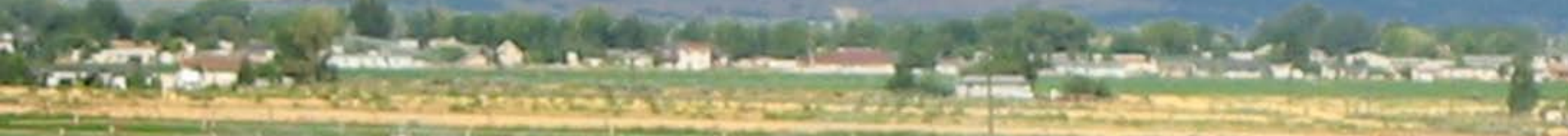

Prepared in cooperation with the

Central Iron County Water Conservancy District,

Utah Department of Natural Resources, Division of Water Resources;

Utah Department of Environmental Ouality, Division of Water Ouality;

Cedar City, and Gity of Enoch

\section{U.S. Department of the Interior \\ U.S. Geological Survey}


Cover: Photograph showing Cedar Valley, Iron County, Utah, taken August 2005 by J.H. Howells, U.S. Geological Survey. 


\section{Hydrology and Simulation of Ground-Water Flow in Cedar Valley, Iron County, Utah}

By Lynette E. Brooks and James L. Mason

Prepared in cooperation with the

CENTRAL IRON COUNTY WATER CONSERVANCY DISTRICT; UTAH DEPARTMENT OFNATURAL

RESOURCES, DIVISION OFWATER RESOURCES; UTAH DEPARTMENT OF ENVIRONMENTAL OUALITY, DIVISION OFWATER QUALITY; CEDAR CITY; AND CITY OF ENOCH

Scientific Investigations Report 2005-5170 


\section{U.S. Department of the Interior Gale A. Norton, Secretary}

\section{U.S. Geological Survey \\ P. Patrick Leahy, Acting Director}

Salt Lake City, Utah, 2005

For more information about the USGS and its products:

Telephone: 1-888-ASK-USGS

World Wide Web: http://www.usgs.gov/

Any use of trade, product, or firm names in this publication is for descriptive purposes only and does not imply endorsement by the U.S. Government.

Although this report is in the public domain, it contains copyrighted materials that are noted in the text. Permission to reproduce those items must be secured from the individual copyright owners.

For additional information, write to:

Director, Utah Water Science Center

U.S. Geological Survey

2329 West Orton Circle

Salt Lake City, Utah 84119

http://ut.water.usgs.gov 


\section{CONTENTS}

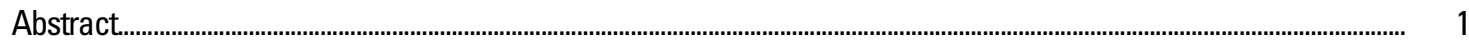

Introduction..................................................................................................................................................................... 2

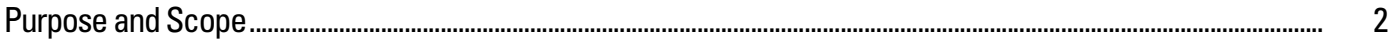

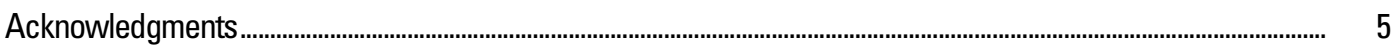

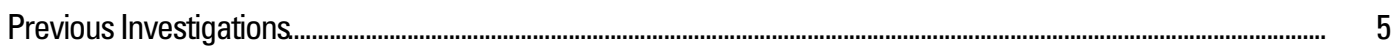

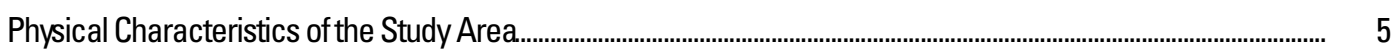

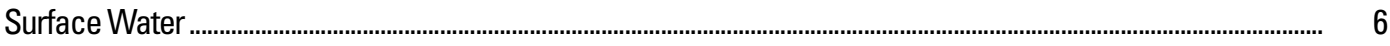

Hydrology of the Ground-Water System................................................................................................................................... 8

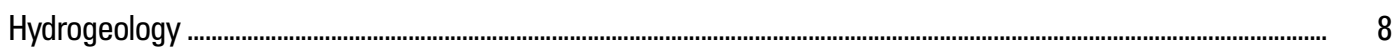

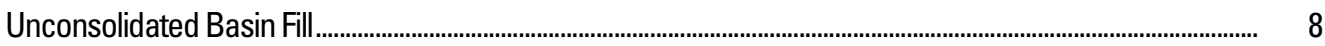

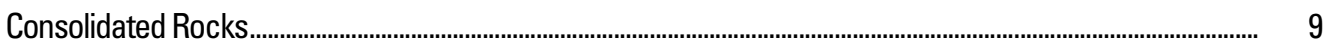

Ground-Water Conditions in the Unconsolidated Basin Fill................................................................................... 10

Aquifer Properties.

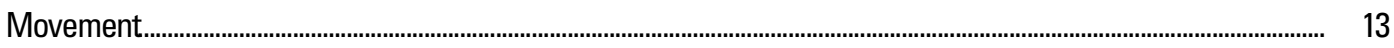

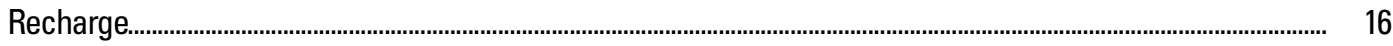

Seepage from Streams ................................................................................................................ 16

Seepage from Irrigation Water ...................................................................................................................... 17

Precipitation ............................................................................................................................................. 18

Subsurface Inflow................................................................................................................................... 19

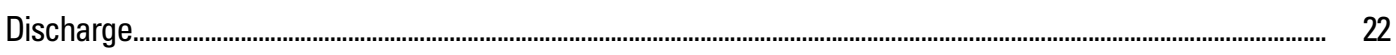

Wells..................................................................................................................................................... 22

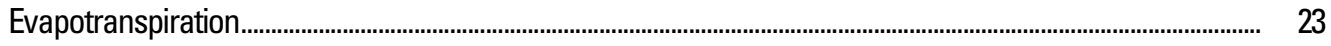

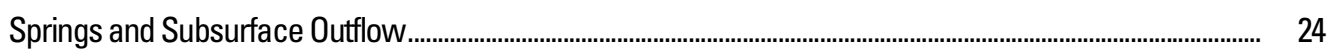

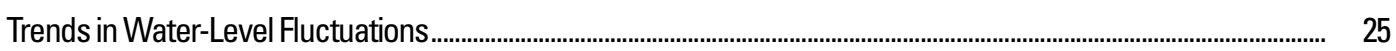

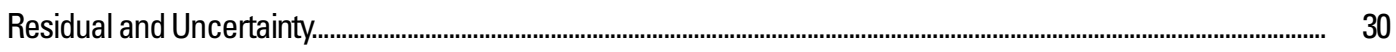

Water Quality and its Implications for Ground-Water Flow..................................................................................................... 31

Major-Ion Chemistry................................................................................................................................... 31

Isotope Chemistry............................................................................................................................................ 35

Ground-Water Age Dating and Recharge Temperature............................................................................................ 39

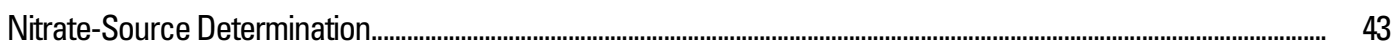

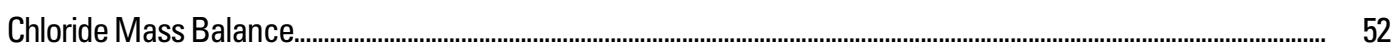

Numerical Simulation of Ground-Water Flow in the Unconsolidated Basin Fill............................................................... 55

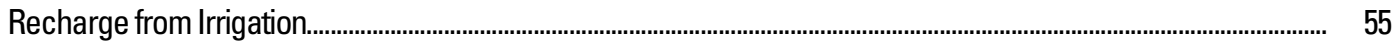

Recharge during 1938-49........................................................................................................................ 55

Recharge during 1950-2000 .................................................................................................................. 57

Percent-Recharge Method............................................................................................................................ 57

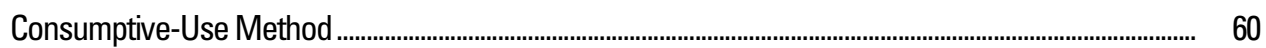

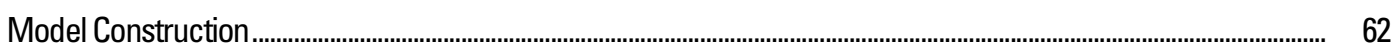

Spatial Discretization............................................................................................................................................ 62

Temporal Discretization ................................................................................................................................... 64

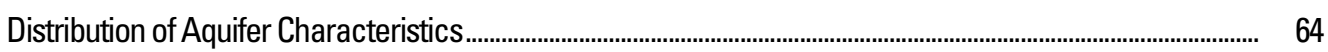


Hydraulic Conductivity and Horizontal-to-Vertical Anisotropy...................................................................... 64

Specific Yield and Specific Storage........................................................................................................................ 64

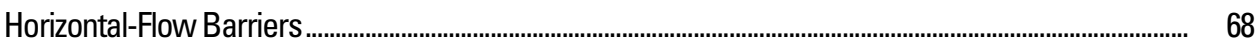

Boundary Conditions ............................................................................................................................................... 68

No-Flow Boundaries................................................................................................................................................. 68

Recharge Boundaries............................................................................................................................ 68

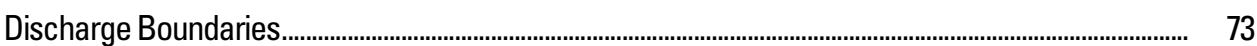

Model Calibration .................................................................................................................................................... 78

Parameter Adjustment and Sensitivity ................................................................................................................ $\quad 79$

Irrigation Zones..................................................................................................................

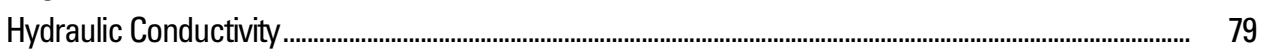

Evapotranspiration............................................................................................................................. 81

Inflow from Consolidated Rock and Parowan Valley................................................................................. 81

Other Parameters....................................................................................................................................... 81

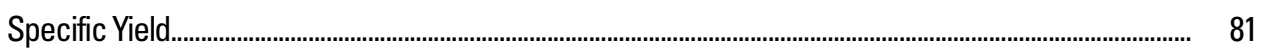

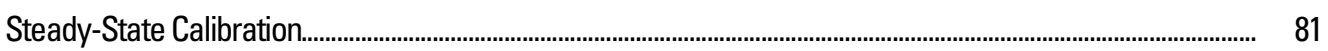

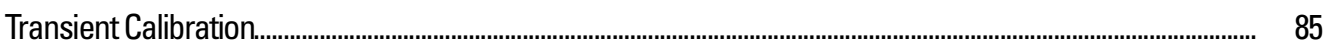

Parameter Correlation, Sensitivity Analysis, and Need for Additional Data............................................................... 94

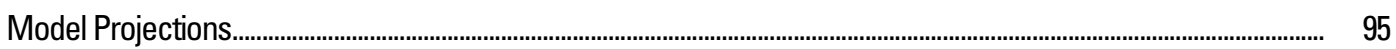

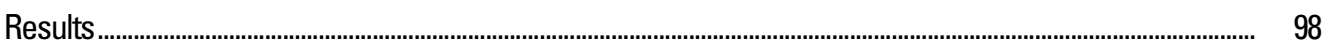

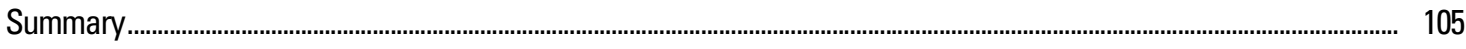

References Cited..................................................................................................................................................................................... 110 


\section{FIGURES}

Figure 1. Location of Cedar Valley study area, Iron County, Utah .......................................................... 3

Figure 2. Numbering system used for hydrologic-data sites in Utah ....................................................

Figure 3. Annual discharge in Coal Creek as measured at U.S. Geological Survey streamflow-gaging station 10242000, near Cedar City, Utah

Figure 4. Estimated percentage of sand/gravel-bearing intervals in the unconsolidated basin fill, Cedar Valley, Iron County, Utah

Figure 5. Approximate potentiometric surface for the unconsolidated basin fill, March 2000, Cedar Valley, Iron County, Utah .

Figure 6. Areas of estimated subsurface inflow from adjacent consolidated rock to the unconsolidated basin fill, Cedar Valley, Iron County, Utah.

Figure 7. Ground-water withdrawal in Cedar Valley, Iron County, Utah...

Figure 8. Relation of water levels in well (C-36-11)8aab-1 to cumulative departure from the average annual precipitation, Cedar Valley, Iron County, Utah..

Figure 9. Approximate area where water levels in wells are affected by (1) long-term precipitation and ground-water withdrawal, (2) yearly snowmelt runoff and groundwater withdrawal, and (3) long-term discharge, Cedar Valley, Iron County, Utah.

Figure 10. Relation of water levels in selected wells to cumulative departure from the average annual flow in Coal Creek, Cedar Valley, Iron County, Utah...

Figure 11. Location of sites sampled for chemical analysis, Cedar Valley, Iron County, Utah.

Figure 12. Relation of streamflow to specific conductance in Coal Creek at U.S. Geological Survey streamflow-gaging station 10242000, near Cedar City, Iron County, Utah..

Figure 13. Chemical composition of surface-water samples collected at selected sites in Cedar Valley, Iron County, Utah

Figure 14. Approximate distribution of dissolved-solids concentration in water collected from selected wells, Cedar Valley, Iron County, Utah

Figure 15. Chemical composition of water collected from selected wells, Cedar Valley, Iron County, Utah.

Figure 16. Relation between $\delta^{2} \mathrm{H}$ and $\delta^{18} 0$ values for ground-water, surface-water, and precipitation samples collected at selected sites, Cedar Valley, Iron County, Utah

Figure 17. Approximate distribution for nitrate concentration in water collected from selected wells, 1999-2001, Cedar Valley, Iron County, Utah

Figure 18. Relation of $\delta^{15} \mathrm{~N}$ and $\delta^{18} \mathrm{O}$ values in the nitrate anion for water collected from selected wells, Cedar Valley, Iron County, Utah, to the range of those values for various nitrogen sources.

Figure 19. Relation between $\delta^{15} \mathrm{~N}$ values in the nitrate anion for water collected from selected wells and the approximate potentiometric surface for March 2000 in Cedar Valley, Iron County, Utah 
Figure 20. Relation of bromide to chloride concentrations in ground-water, surface-water, and precipitation samples, Cedar Valley, Iron County, Utah

Figure 21. Area of estimated evenly distributed recharge from irrigation, Cedar Valley, Iron County, Utah........................................................................................................................ 56

Figure 22. Surface-water irrigation areas, Cedar Valley, Iron County, Utah......................................... 58

Figure 23. Ground-water irrigation areas, Cedar Valley, Iron County, Utah......................................... 59

Figure 24. Model grid and approximate simulated thickness of the unconsolidated basin fill in the ground-water flow model, Cedar Valley, Iron County, Utah...

Figure 25. Horizontal-flow barriers and percentage of coarse material used as a multiplier array for hydraulic conductivity simulated in the ground-water flow model, Cedar Valley, Iron County, Utah

Figure 26. Parameters for hydraulic conductivity simulated in the ground-water flow model, Cedar Valley, Iron County, Utah.

Figure 27. Distribution of hydraulic conductivity simulated in the ground-water flow model, Cedar Valley, Iron County, Utah.

Figure 28. Distribution of recharge from irrigation simulated in the steady-state groundwater flow model, Cedar Valley, Iron County, Utah

Figure 29. Parameters for recharge from irrigation simulated in the steady-state ground -water flow model, Cedar Valley, Iron County, Utah.

Figure 30. Distribution of inflow from consolidated rock and Parowan Valley simulated in the steady-state ground-water flow model, Cedar Valley, Iron County, Utah

Figure 31. Distribution of evapotranspiration, springs, and general-head boundaries simulated in the ground-water flow model, Cedar Valley, Iron County, Utah.

Figure 32. Distribution of withdrawal from wells simulated in the steady-state groundwater flow model, Cedar Valley, Iron County, Utah

Figure 33. Distribution of withdrawal from wells simulated for 2000 in the transient groundwater flow model, Cedar Valley, Iron County, Utah

Figure 34. Composite scaled sensitivity of observations to (A) original, and (B) final model parameters simulated in the steady-state ground-water flow model, Cedar Valley, Iron County, Utah

Figure 35. Final distribution of horizontal-to-vertical anisotropy of hydraulic conductivity simulated in the ground-water flow model, Cedar Valley, Iron County, Utah.

Figure 36. Final distribution of specific yield and specific storage simulated in the groundwater flow model, Cedar Valley, Iron County, Utah

Figure 37. Water level simulated in the steady-state ground-water flow model, and difference between simulated water level and water level measured in March 1939 and March 1950, Cedar Valley, Iron County, Utah.

Figure 38. Water level simulated at the end of each stress period in the transient groundwater flow model and water level measured from March 1939 to March 2001, Cedar Valley, Iron County, Utah 
Figure 39. Water level simulated at the end of stress period 62 in the transient ground-water flow model and difference between simulated water level and water level measured in March 2000, Cedar Valley, Iron County, Utah.

Figure 40. Location of simulated water levels with highest one-percent scaled sensitivity in layer 2 to selected model parameters simulated in the steady-state groundwater flow model, Cedar Valley, Iron County, Utah.

Figure 41. Drawdown and water level in model layer 2 at the end of 30-year simulation, projection 1 of the ground-water flow model, Cedar Valley, Iron County, Utah

Figure 42. Drawdown and water level in model layer 2 at the end of 30-year simulation, projection 2 of the ground-water flow model, Cedar Valley, Iron County, Utah

Figure 43. Drawdown and water level in model layer 2 at the end of 30-year simulation, projection 3 of the ground-water flow model, Cedar Valley, Iron County, Utah

Figure 44. Drawdown and water level in model layer 2 at the end of 30-year simulation, projection 4 of the ground-water flow model, Cedar Valley, Iron County, Utah

Figure 45. Drawdown and water level in model layer 2 at the end of 30-year simulation, projection 5 of the ground-water flow model, Cedar Valley, Iron County, Utah

Figure 46. Drawdown and water level in model layer 2 at the end of 30-year simulation, projection 6 of the ground-water flow model, Cedar Valley, Iron County, Utah

Figure 47. Location of selected simulated water-level fluctuations for model projections of the ground-water flow model, Cedar Valley, Iron County, Utah

Figure 48. Simulated water-level fluctuations for model projections of the ground-water flow model, Cedar Valley, Iron County, Utah. 


\section{TABLES}

Table 1. Mean monthly streamflow for 1939-2000 and monthly mean streamflow for 1998-2000 as measured at U.S. Geological Survey streamflow-gaging station 10242000 on Coal Creek near Cedar City, Utah

Table 2. Ground-water budget prior to large-scale development and for 2000, Cedar Valley, Iron County, Utah

Table 3. Average annual precipitation and recharge for contributing areas, Cedar Valley, Iron County, Utah.

Table 4. Map and local identifier and chemical analyses done for water from each sampling site, Cedar Valley, Iron County, Utah.

Table 5. $\mathrm{d} 2 \mathrm{H}$ and $\mathrm{d} 180$ values in ground-water, surface-water, and precipitation samples from selected sites, Cedar Valley, Iron County, Utah.

Table 6. Chlorofluorocarbon concentration in ground-water samples and apparent recharge date for different assumed recharge temperatures, Cedar Valley, Iron County, Utah

Table 7. Dissolved gas, tritiogenic helium-3, and tritium concentrations, apparent age, and recharge temperature for ground-water samples collected from selected wells, Cedar Valley, Iron County, Utah

Table 8. Concentration of dissolved nitrogen species and nitrogen and oxygen isotope ratios in the nitrate anion for water samples collected from selected sites, Cedar Valley, Iron County, Utah

Table 9. Conceptual annual recharge from irrigation with surface water and seepage from Coal Creek, Cedar Valley, Iron County, Utah, 1938-49.

Table 10. Conceptual annual recharge from irrigation with ground water, Cedar Valley, Iron County, Utah, 1938-49

Table 11. Conceptual annual recharge from irrigation for selected years determined by different methods of calculation, Cedar Valley, Iron County, Utah.

Table 12. Land use and consumptive use of water by crops, Cedar Valley, Iron County, Utah, 1989.

Table 13. Annual precipitation, precipitation multiplier, and inflow multiplier used to calculate annual variation of inflow from consolidated rock in the transient ground-water flow model, Cedar Valley, Iron County, Utah.

Table 14. Conceptual ground-water budget for 1938-49, and ground-water budget simulated in the steady-state ground-water flow model, Cedar Valley, Iron County, Utah.

Table 15. Conceptual ground-water budget for 2000 and ground-water budget simulated in stress period 63 of the transient ground-water flow model, Cedar Valley, Iron County, Utah.

Table 16. Observations with the highest one-percent scaled sensitivity in layer 2 to selected model parameters simulated in the steady-state ground-water flow model, Cedar Valley, Iron County, Utah

Table 17. Ground-water budget for the steady-state simulation, stress period 63 of the transient simulation, and projected 30-year simulations, Cedar Valley, Iron County, Utah 


\section{Conversion Factors, Datums, and Abbreviated Water-Quality Units}

\begin{tabular}{lcl}
\hline Multiply & By & To obtain \\
\hline acre & 4,047 & square meter \\
acre & 0.4047 & square hectometer \\
acre & 0.004047 & square kilometer \\
acre-foot (acre-ft) & 1,233 & cubic meter \\
acre-foot per year (acre-ft/yr) & 1,233 & cubic meter per year \\
acre-foot per year (acre-ft/yr) & 0.001233 & cubic hectometer per year \\
cubic foot per second $\left(\mathrm{ft}^{3} / \mathrm{s}\right)$ & 0.02832 & cubic meter per second \\
foot $(\mathrm{ft})$ & 0.3048 & meter \\
foot per day (ft/d) & 0.3048 & meter per day \\
foot per mile $(\mathrm{ft} / \mathrm{mi})$ & 0.1894 & meter per kilometer \\
foot per year $(\mathrm{ft} / \mathrm{yr})$ & 0.3048 & meter per year \\
foot squared per day $\left(\mathrm{ft}^{2} / \mathrm{d}\right)$ & 0.0929 & meter squared per day \\
inch (in.) & 2.54 & centimeter \\
inch (in.) & 25.4 & millimeter \\
inch per year $(\mathrm{in} / \mathrm{yr})$ & 25.4 & millimeter per year \\
mile (mi) & 1.609 & kilometer \\
square mile $\left(\mathrm{mi}{ }^{2}\right)$ & 2.590 & square kilometer \\
\hline
\end{tabular}

Vertical coordinate information is referenced to the National Geodetic Vertical Datum of 1929 (NGVD 1929). Horizontal coordinate information is referenced to the North American Datum of 1983 (NAD 83).

Temperature is reported in degrees Celsius $\left({ }^{\circ} \mathrm{C}\right)$ or degrees Fahrenheit $\left({ }^{\circ} \mathrm{F}\right)$. Each temperature scale can be converted to the other by using the following equations:

$$
\begin{aligned}
& { }^{0} \mathrm{~F}=1.8\left({ }^{\circ} \mathrm{C}\right)+32 \\
& { }^{\circ} \mathrm{C}=\left({ }^{0} \mathrm{~F}-32\right) / 1.8 .
\end{aligned}
$$

Specific conductance is reported in microsiemens per centimeter at 25 degrees Celsius $(\mu \mathrm{S} / \mathrm{cm})$.

Chemical concentration in water generally is reported in milligrams per liter $(\mathrm{mg} / \mathrm{L})$ or micrograms per liter $(\mu \mathrm{g} / \mathrm{L})$. These units express the concentration of chemical constituents in solution as weight (grams) of solute per unit volume (liter) of water. A liter of water is assumed to weigh 1 kilogram. Exceptions to this assumption include brines and water at high temperatures, both of which result in changes to the density of water. For concentrations less than $7,000 \mathrm{mg} / \mathrm{L}$, the numerical value is equivalent to concentrations expressed as parts per million.

Chlorofluorocarbons are reported in picomoles per kilogram (pmole/ $\mathrm{kg}$ ). This would be equivalent to parts per quadrillion. A mole is the mass, in grams, that is numerically equal to the sum of atomic weights of all atoms in a molecule. A millimole (mmole) is 1/1,000th of a mole.

Tritium $\left({ }^{3} \mathrm{H}\right)$ and tritiogenic helium-3 $\left({ }^{3} \mathrm{He}\right)$ concentrations in ground water are reported in tritium units (TU), where 1 TU is the ratio of 1 atom of tritium to $10^{18}$ atoms of hydrogen or 3.2 picocuries per liter.

Dissolved-gas concentrations are reported in cubic centimeters at standard temperature and pressure per gram of water $\left(\mathrm{cm}^{3} \mathrm{STP} / \mathrm{g}\right)$. 


\title{
Hydrology and Simulation of Ground-Water Flow in Cedar Valley, Iron County, Utah
}

\author{
By Lynette E. Brooks and James L. Mason
}

\section{Abstract}

Cedar Valley, located in the eastern part of Iron County in southwestern Utah, is experiencing rapid population growth. Cedar Valley traditionally has supported agriculture, but the growing population needs a larger share of the available water resources. Water withdrawn from the unconsolidated basin fill is the primary source for public supply and is a major source of water for irrigation. Water managers are concerned about increasing demands on the water supply and need hydrologic information to manage this limited water resource and minimize flow of water unsuitable for domestic use toward present and future public-supply sources.

Surface water in the study area is derived primarily from snowmelt at higher altitudes east of the study area or from occasional large thunderstorms during the summer. Coal Creek, a perennial stream with an average annual discharge of 24,200 acre-feet per year, is the largest stream in Cedar Valley. Typically, all of the water in Coal Creek is diverted for irrigation during the summer months. All surface water is consumed within the basin by irrigated crops, evapotranspiration, or recharge to the ground-water system.

Ground water in Cedar Valley generally moves from primary recharge areas along the eastern margin of the basin where Coal Creek enters, to areas of discharge or subsurface outflow. Recharge to the unconsolidated basin-fill aquifer is by seepage of unconsumed irrigation water, streams, direct precipitation on the unconsolidated basin fill, and subsurface inflow from consolidated rock and Parowan Valley and is estimated to be about 42,000 acre-feet per year. Stable-isotope data indicate that recharge is primarily from winter precipitation. The chloride mass-balance method indicates that recharge may be less than 42,000 acre-feet per year, but is considered a rough approximation because of limited chloride concentration data for precipitation and Coal Creek. Continued declining water levels indicate that recharge is not sufficient to meet demand. Water levels in many areas are at or close to historic lows.

In 2000, withdrawal from wells was estimated to be 36,000 acre-feet per year. About 4,000 acre-feet per year are estimated to discharge to evapotranspiration or as subsurface outflow. Prior to large-scale ground-water development, ground-water discharge by evapotranspiration and discharge to springs was much larger.

Ground water along the eastern margin of the valley between Cedar City and Enoch is unsuitable for domestic use because of high dissolved-solids and nitrate concentrations. The predominant ions of calcium and sulfate in this area indicate dissolution of gypsum in the Markagunt Plateau to the east. Data collected during this study were compared to historic data; there is no evidence to indicate deterioration in ground-water quality. The spatial distribution of ground water with high nitrate concentration does not appear to be migrating beyond its previously known extent.

No single source can be identified as the cause for elevated nitrate concentrations in ground water. Low nitrogen-15 values north of Cedar City indicate a natural geologic source. Higher nitrogen-15 values toward the center of the basin and associated hydrologic data indicate probable recharge from waste-water effluent. Excess dissolved nitrogen gas and low nitrate concentrations in shallow ground water indicate that denitrification is occurring in some areas.

A computer ground-water flow model was developed to simulate flow in the unconsolidated basin fill. The method of determining recharge from irrigation was changed during the calibration process to incorporate more areal and temporal variability. In general, the model accurately simulates water levels and water-level fluctuations and can be considered an adequate tool to help determine the valley-wide effects on water levels of additional ground-water withdrawals and changes in water use. The model was used to simulate water-level changes caused by projecting current withdrawal rates, increased 


\section{Hydrology and Simulation of Ground-Water Flow in Cedar Valley, Iron County, Utah}

withdrawal rates, and a 10-year drought. Water levels declined 20 to 275 feet in the southern and central parts of the valley and less than 20 feet north of Enoch.

\section{Introduction}

The Cedar Valley study area is located in the eastern part of Iron County in southwestern Utah (fig. 1). Cedar Valley, which traditionally has supported agriculture, is experiencing rapid population growth, and the growing population requires a larger share of the available water resources. The municipal and residential water supply is primarily ground water pumped from the unconsolidated basin fill, with additional water obtained from springs discharging from consolidated rocks in the surrounding mountains. Ground water is also a major source of irrigation water.

Water managers are concerned about increasing demands on the water supply and need quantitative hydrologic information to develop a plan that would minimize the flow of water that is not suitable for domestic use toward present and future public-supply sources and that would develop an adequate water supply without infringing on the rights of other water users. The U.S. Geological Survey (USGS), in cooperation with the Central Iron County Water Conservancy District; Utah Department of Natural Resources, Division of Water Resources; Utah Department of Environmental Quality, Division of Water Quality; Cedar City; and city of Enoch, completed a study of the water resources of the area from July 1997 to December 2002.

The principal objective of the study is to define the hydrology and geochemistry of the principal unconsolidated basin-fill aquifer in Cedar Valley. Specific objectives include:

- Define the geologic character, physical dimensions, and hydrologic properties of the basin-fill aquifer and its relation to adjacent consolidated rocks

- Determine the direction and rate of ground-water movement

- Define the spatial and temporal variations in the chemical composition of ground water

- Investigate the processes responsible for the variations in the chemical composition of ground water

- Evaluate the effects of current and possible future ground-water withdrawals on the hydrologic system.
The USGS study was divided into two phases: a data-collection phase and a synthesis and interpretation phase. The data-collection phase was concurrent with an assessment of the geologic framework of the study area completed by the Utah Geological Survey.

During the first phase, hydrologic data were collected to provide a basis for a better understanding of the hydrologic system. Water levels were measured in about 135 wells in March and November during 1999-2000. Water samples for chemical analysis were collected from 44 wells during 1999-2001. Water samples also were collected from streams for chemical analysis. Seepage measurements were made along Coal Creek downstream from the USGS streamflow-gaging station and along the main irrigation canals. These data, along with data collected by the USGS prior to this study, are reported in Howells and others (2002). Specific data-collection sites are shown in figures in this report as they pertain to appropriate discussions. The numbering system used for hydrologic-data sites in Utah is shown in figure 2.

The second phase incorporated hydrologic, chemical, and geologic data to develop a conceptual and a three-dimensional numerical model of ground-water flow in Cedar Valley. Isotopic analyses were used to identify possible sources of the ground water and of specific chemical constituents. Water-quality data were compared to previous data to ascertain possible temporal changes. Aquifer geometry, hydraulic properties, and recharge and discharge processes were calculated or estimated. These parameters were incorporated into a three-dimensional numerical model that simulates ground-water flow in the unconsolidated basin fill of Cedar Valley.

\section{Purpose and Scope}

The purpose of this report is to describe the hydrologic system and to document the quality and quantity of the water resources in Cedar Valley, southwestern Utah. This report summarizes estimates of recharge to and discharge from the ground-water system, water quality of surface and ground water, and development of a threedimensional flow model that simulates ground-water flow in the unconsolidated basin fill in Cedar Valley. 


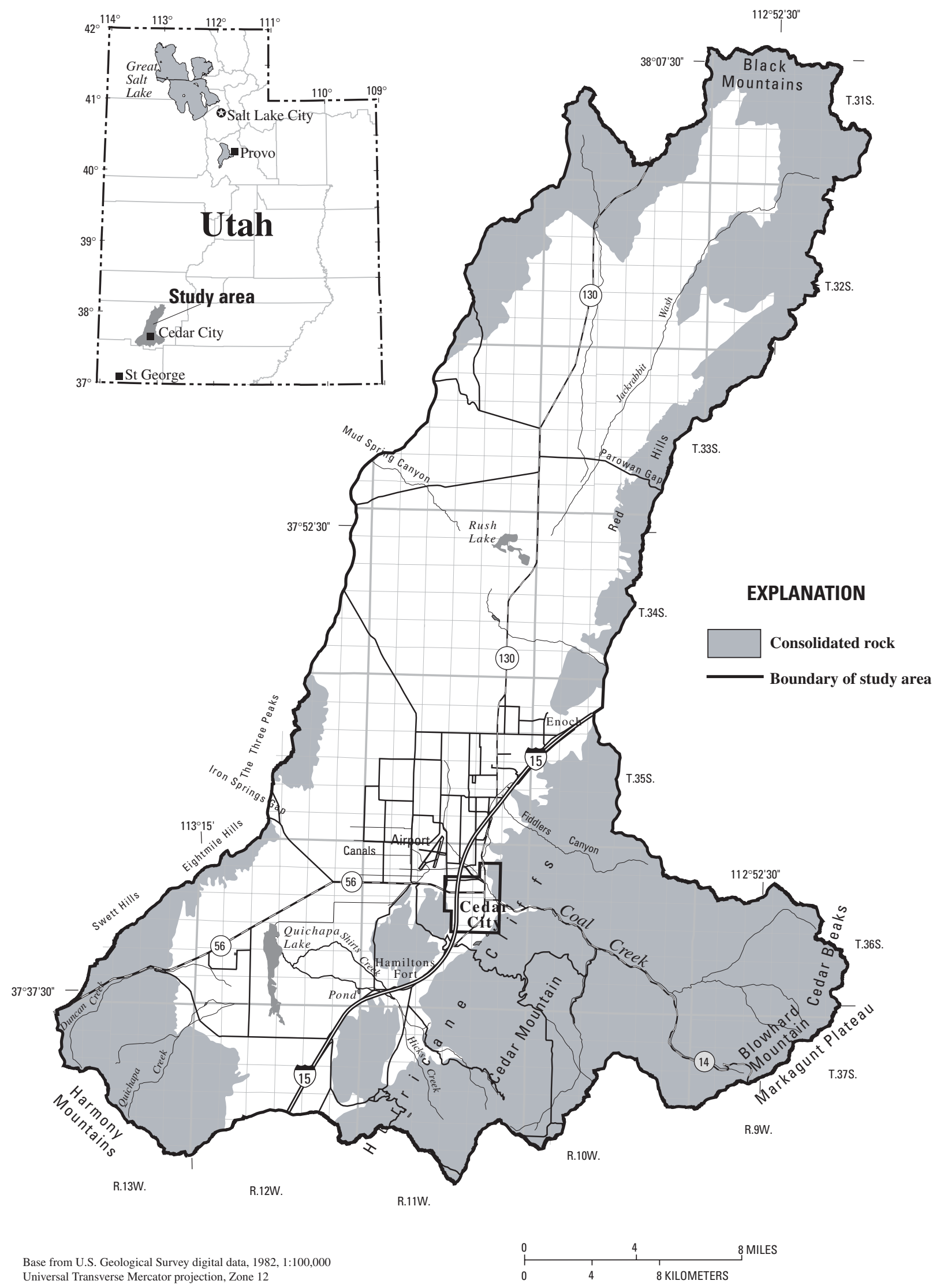

Figure 1. Location of Cedar Valley study area, Iron County, Utah. 
The system of numbering wells and springs in Utah is based on the cadastral land-survey system of the U.S. Government. The number, in addition to designating the well or spring, describes its position in the land net. The land-survey system divides the State into four quadrants separated by the Salt Lake Base Line and the Salt Lake Meridian. These quadrants are designated by the uppercase letters A, B, $\mathrm{C}$, and $\mathrm{D}$, indicating the northeast, northwest, southwest, and southeast quadrants, respectively. Numbers designating the township and range, in that order, follow the quadrant letter, and all three are enclosed in parentheses. The number after the parentheses indicates the section and is followed by three letters indicating the quarter section, the quarter-quarter section, and the quarter-quarter-quarter section-generally 10 acres for a regular section ${ }^{1}$. The lowercase letters a, b, c, and d indicate, respectively, the northeast, northwest, southwest, and southeast quarters of each subdivision. The number after the letters is the serial number of the well or spring within the 10-acre tract. When the serial number is not preceded by a letter, the number designates a well. When the serial number is preceded by an "S", the number designates a spring. A number having all three quarter designations but no serial number indicates a miscellaneous data site other than a well or spring, such as a location for a surface-water measurement site. Thus, (C-35-12)25ddd-1 designates the first well constructed or visited in the southeast quarter of the southeast quarter of the southeast quarter of section 25 , T. 35 S., R. $12 \mathrm{~W}$.

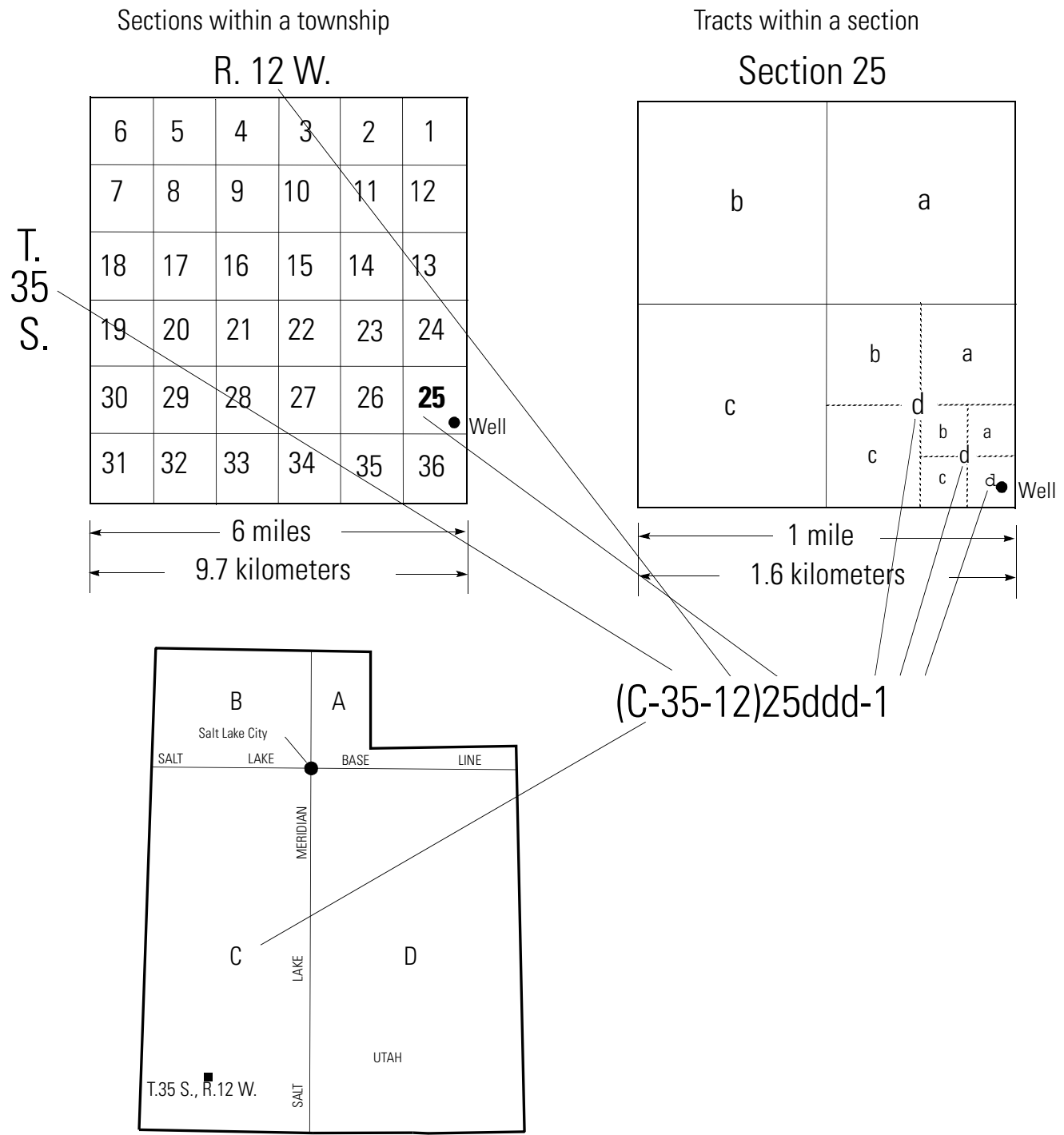

${ }^{1}$ Although the basic land unit, the section, is theoretically 1 square mile, many sections are irregular in size and shape. Such sections are subdivided into 10-acre tracts, generally beginning at the southeast corner, and the surplus or shortage is taken up in the tracts along the north and west sides of the section.

Figure 2. Numbering system used for hydrologic-data sites in Utah. 


\section{Acknowledgments}

The success of this study would not have been possible without the cooperation of individual landowners who allowed access to their wells. Special acknowledgment is given to Cedar City and city of Enoch employees for making data available and allowing access to municipal wells. Special thanks is given to Frank Nichols, Matt Bulloch, and Kay Griffiths for allowing a monitoring well to be drilled on their property.

\section{Previous Investigations}

Early reconnaissance of geology in the study area dates back to the latter part of the $19^{\text {th }}$ century and is published in reports that cover much larger areas. The first detailed geologic studies focused on the coal and iron ore resources of the area. Geologic maps that cover the study area have been produced by Averitt (1967), Averitt and Threet (1973), Rowley (1975, 1976), Mackin and others (1976), Mackin and Rowley (1976), and Rowley and Threet (1976). Structural geologic studies of the area were completed by Averitt (1962), Threet (1963), and Stewart and others (1972a, b). Most recent geologic studies examined the Cedar Valley area as a part of regionalscale studies on the transition between the Basin and Range and Colorado Plateau (Maldonado, 1995; Maldonado and others, 1997; Williams and Maldonado, 1995; and Rowley, 1998). A summary of previous geologic studies and new interpretations of basin-fill stratigraphy are presented in Hurlow (2002).

The earliest study of water resources in Cedar Valley is part of a larger regional reconnaissance study of western and southwestern Utah completed by Meinzer (1911). In Meinzer's report, Cedar Valley is named Rush Lake Valley. The first comprehensive study of geology and water resources in the area was completed by Thomas and Taylor (1946). This report describes the water resources of Cedar and Parowan Valleys and provides information about the early stages of ground-water development in Cedar Valley. A brief description of the status of ground-water development is presented in Thomas and others (1952, p. 22-34). Additional hydrologic information was published by Barnell and Nelson in a report by Waite and others (1954, p. 75-84). Sandberg $(1963,1966)$ describes the water resources of selected basins in southwestern Utah. Bjorklund and others $(1977,1978)$ describe the water resources of Cedar and Parowan Valleys. Numerous reports concerning well- head protection at specific sites in Cedar Valley have been completed in recent years and can be viewed at the offices of the Utah Division of Drinking Water.

\section{Physical Characteristics of the Study Area}

Cedar Valley is located along the eastern margin of the Great Basin at the transition between the Basin and Range and Colorado Plateau Physiographic Provinces (Fenneman, 1931). The Cedar Valley drainage basin covers an area of about $570 \mathrm{mi}^{2}$. The valley is bounded by the Markagunt Plateau on the east, Harmony Mountains on the southwest, The Three Peaks on the west, and Black Mountains to the north. The valley floor covers about $170 \mathrm{mi}^{2}$ (Bjorklund and others, 1978, p. 5). A welldefined alluvial fan is present on the east margin of the basin where Coal Creek drains part of the Markagunt Plateau. Altitudes in the Cedar Valley drainage basin range from about 5,300 $\mathrm{ft}$ in the northern part of the valley at Mud Spring Canyon to 10,400 ft at Blowhard Mountain on the plateau to the east.

Cedar Valley is a topographically open basin with three gaps to the northwest, west, and south (fig. 1). A slight topographic high extends from near Iron Springs Gap to the alluvial fan formed from the outwash of the Coal Creek drainage and divides Cedar Valley into two subbasins. In much of the northern part of the valley, the valley floor slopes to the northwest toward Mud Springs Canyon and west toward Iron Springs Gap. In the past, some surface water has exited the valley through these gaps toward the Escalante Desert during periods of large amounts of local precipitation. Small amounts of ground water flow out of the valley through these two gaps. It is assumed that little or no ground water flows out of the valley to the south.

The climate in Cedar Valley varies from semiarid on the valley floor to more humid conditions at the top of the Markagunt Plateau to the east. Average annual precipitation (1961-90) on the valley floor ranges from less than $11 \mathrm{in}$. at the northern end to about $16 \mathrm{in}$. at the southern end of the valley (Utah Climate Center, 1996). The average annual precipitation at the Cedar City airport from 1949 to 2004 was 10.60 in. (Western Regional Climate Center, 2005). Maximum average annual precipitation for the study area is about 35 in. near the headwaters of Coal Creek in the Markagunt Plateau. Maximum average annual precipitation in the New Harmony Mountains in the southwest is about $23 \mathrm{in}$. The wettest months are March and April with frequent storms from the northwest, and July and August when monsoonal thunderstorms enter the area from the southwest. Much of the 


\section{Hydrology and Simulation of Ground-Water Flow in Cedar Valley, Iron County, Utah}

precipitation at higher altitudes in the Markagunt Plateau occurs from January through April and August through October as recorded at Brianhead, Utah, located about 12 mi east of Cedar City. Average monthly maximum temperature at the Cedar City Airport ranges from a low of $17.5^{\circ} \mathrm{F}$ in January to a high of $90.0^{\circ} \mathrm{F}$ in July.

Land use in Cedar Valley is varied and has been changing in recent years with increasing population. Much of the northern part of the basin is open rangeland. Most of the central part of the basin between Cedar City and Enoch and to the western margin is irrigated primarily for growing alfalfa in the summer and used for limited grazing in the winter. In addition, a small amount of land north of Enoch is irrigated cropland. Some fallow and unused rangeland has been converted to residential subdivisions and light industrial use along the Highway 56 corridor (fig. 1). In the southern part of the basin, much of the area is unused rangeland with some irrigated cropland and an increasing amount of land used for rural residential property.

\section{Surface Water}

Surface water in the study area is derived primarily from snowmelt runoff at higher altitudes on the Markagunt Plateau east of Cedar City or from occasional, large thunderstorms throughout the drainage basin during the summer. Coal Creek is the largest perennial stream (and only gaged stream) in Cedar Valley. Shirts Creek (alternatively named Shurtz Creek) is the only other perennial stream in Cedar Valley; its streamflow is small compared to that of Coal Creek.

Coal Creek provides almost all of the surface water used for irrigation in the basin. The majority of the water in Coal Creek is diverted during the irrigation season into a complex system of ditches near the canyon mouth or within about 3 mi downstream. Some streamflow during periods of high snowmelt runoff and some of the base flow during the winter is allowed to continue in the stream channel. A recently constructed extension to an irrigation ditch allows much of the streamflow to be diverted to Quichapa Lake during the winter with the remainder flowing through smaller ditches. All surface water is consumed within the basin by irrigated crops, evapotranspiration, or recharge to the ground-water system.

A USGS streamflow-gaging station on Coal Creek (station number 10242000) is located $1.2 \mathrm{mi}$ east of Cedar City. This streamflow-gaging station has been operated intermittently from May 1915 through September 1937 and continuously from April 1938 to 2005. The measured streamflow is derived from an $80.9 \mathrm{mi}^{2}$ drainage area. The 1939-2000 average annual discharge is 24,200 acre-ft (Burden and others, 2001, fig. 25). Annual discharge has ranged from 7,760 acre-ft for 1977 to 63,890 acre-ft for 1983 (fig. 3). The high streamflow in 1983 occurred during a period in which 9 of the 11 years had greater-than-average annual discharge. The annual discharge during the data-collection phase of this study was 47,360 acre-ft for 1998, 21,850 acre-ft for 1999, and 17,360 acre-ft for 2000 .

Mean monthly streamflows (table 1), indicate that the highest streamflow caused by snowmelt runoff occurs during April through June. Mean monthly values for July and August are larger than the base-flow period of September through March because of the prevalence of monsoonal thunderstorms.

Table 1. Mean monthly streamflow for 1939-2000 and monthly mean streamflow for 1998-2000 as measured at U.S. Geological Survey streamflow-gaging station 10242000 on Coal Creek near Cedar City, Utah

\begin{tabular}{lcccc}
\hline Month & $\begin{array}{c}\text { Mean } \\
\text { monthly } \\
\text { streamflow } \\
\mathbf{1 9 3 9 - 2 0 0 0} \\
\text { (cubic feet } \\
\text { per second) }\end{array}$ & $\begin{array}{c}\text { Monthlymean } \\
\text { streamflow } \\
\text { 1998 } \\
\text { (cubic feet } \\
\text { per second) }\end{array}$ & $\begin{array}{c}\text { Monthly mean } \\
\text { streamflow } \\
\text { (cubic feet } \\
\text { per second) }\end{array}$ & $\begin{array}{c}\text { Monthly mean } \\
\text { streamflow } \\
\text { 2000 } \\
\text { (cubic feet } \\
\text { per second) }\end{array}$ \\
\hline January & 9.84 & 9.29 & 12.5 & 11.2 \\
February & 11.6 & 10.7 & 13.7 & 12.3 \\
March & 18.4 & 24.3 & 20.4 & 20.1 \\
April & 59.0 & 52.1 & 35.0 & 71.0 \\
May & 149 & 281 & 122 & 82.5 \\
June & 72.3 & 211 & 59.8 & 21.4 \\
July & 23.4 & 58.2 & 29.4 & 10.7 \\
August & 17.5 & 24.6 & 16.5 & 10.0 \\
September & 14.4 & 46.8 & 15.0 & 9.41 \\
October & 12.5 & 25.1 & 11.1 & 10.3 \\
November & 11.3 & 21.8 & 10.2 & 13.2 \\
December & 10.2 & 16.8 & 15.4 & 13.3 \\
\hline
\end{tabular}

Water in Coal Creek is divided into a complex distribution system of canals and ditches on the basis of priority rights as defined by the Coal Creek Decree filed in 1922. Although the decree contains many complexities and subsequent modifications, the brief description provided here is sufficient for the purposes of this study. Water rights acquired prior to the creation of the Utah State Engineer's Office in 1903 were divided into four classes, 1, 2, 3, and 4a, which correspond to rights initiated prior to $1870,1880,1890$, and 1903, respectively. During the irrigation season, water in amounts as much as $25.19 \mathrm{ft}^{3} / \mathrm{s}$ are distributed to class 1 rights, amounts from 25.19 to $35.63 \mathrm{ft}^{3} / \mathrm{s}$ are distributed to class 2 rights, amounts from 35.63 to $38.53 \mathrm{ft}^{3} / \mathrm{s}$ are distributed to 


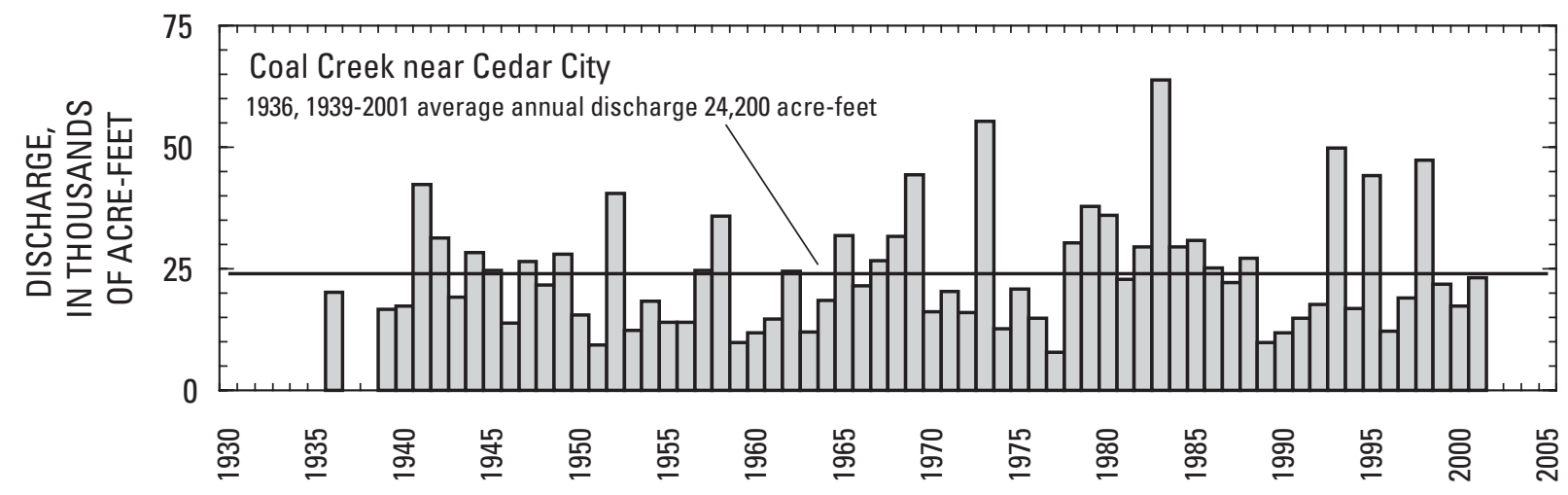

Figure 3. Annual discharge in Coal Creek as measured at U.S. Geological Survey streamflow-gaging station 10242000, near Cedar City, Utah. (From Burden and others, 2002, fig. 25.)

class 3 rights, and amounts from 38.53 to $102.02 \mathrm{ft}^{3} / \mathrm{s}$ are distributed to $4 \mathrm{a}$ rights. Flows in excess of $102.02 \mathrm{ft}^{3} / \mathrm{s}$ not distributed to class 1-4a rights are distributed to low priority rights initiated after 1903 in order of their respective priorities. The distribution of surface water for applied irrigation and its relation to recharge are discussed in more detail in the "Numerical simulation of ground-water flow in the unconsolidated basin fill" section of this report.

Shirts Creek is a perennial stream that is located south of Coal Creek (fig. 1). Along with its tributary Hicks Creek, Shirts Creek has a drainage-basin area of $18.7 \mathrm{mi}^{2}$. Only intermittent streamflow data are available for Shirts Creek. An instantaneous measurement of 0.77 $\mathrm{ft}^{3} / \mathrm{s}$ for Shirts Creek was reported by Thomas and Taylor (1946, p. 69), but they did not specify whether the measurement was made downstream from the confluence with Hicks Creek. During this study, additional instantaneous measurements were made downstream from the confluence near Hamiltons Fort to evaluate whether there is a seasonal trend. These measurements ranged from $0.05 \mathrm{ft}^{3} / \mathrm{s}$ on August 24, 2000, to $2.07 \mathrm{ft}^{3} / \mathrm{s}$ on May 26 , 2000 (Herbert and others, 2000, p. 303; Herbert and others, 2001, p. 347). A crest-stage site, which measures maximum instantaneous streamflow for a given period of time, was located upstream from the confluence with Hicks Creek and maintained by the USGS during 195974. Maximum annual streamflows are reported in the annual water-data reports for Utah. These maximum streamflows ranged from $24 \mathrm{ft}^{3} / \mathrm{s}$ (estimated) on July 23 , 1966 (U.S. Geological Survey, 1967, p. 331), to 1,230 $\mathrm{ft}^{3} / \mathrm{s}$ on August 4, 1964 (U.S. Geological Survey, 1965, p. 276). All but one of these maximum streamflows occurred during July through September and were likely the result of large thunderstorms. Because Hicks Creek is located in an adjacent drainage basin to the upper part of Shirts Creek, the combined maximum streamflow for these runoff events downstream from the confluence probably was much larger.

An estimate for average streamflow in Shirts Creek can be made by the use of regression equations developed by Christensen and others (1986) for estimating average streamflow in ungaged streams. The regression equation for the Southwestern Plateaus Region of the Colorado River Basin was assumed to be appropriate for this application (Christensen and others, 1986, p. 11):

$$
Q=3.54+0.294(A)
$$

where:

$Q=$ average discharge in $\mathrm{ft}^{3} / \mathrm{s}$; and

$A=$ contributing drainage area in $\mathrm{mi}^{2}$.

The average streamflow calculated with this equation is equal to $9 \mathrm{ft}^{3} / \mathrm{s}$. Uncertainties are inherent with the use of this regression equation. The equation was derived from data from only 13 gaged streams in the Southwestern Plateaus Region (Christensen and others, 1986, p. 811). Because this study area is located at the margin of the Southwestern Plateaus Region, the physical characteristics that are indicative of the streamflow regime for the Southwestern Plateaus Region may not be appropriate for the Shirts Creek drainage basin. This streamflow is considerably more than any of the instantaneous measurements mentioned previously, but less than the 24 to $1,230 \mathrm{ft}^{3} / \mathrm{s}$ recorded at the crest-stage site. Even if spring discharge at the head of Shirts Creek, which is diverted 


\section{Hydrology and Simulation of Ground-Water Flow in Cedar Valley, Iron County, Utah}

for municipal use in Cedar City, and an assumed average daily value for water from thunderstorm peak flows were added, the total would be less than the value estimated by equation 1. The lack of flow in the Shirts Creek drainage basin indicates that much of the water from rain or snowmelt infiltrates into rock outcrops through fractures or is consumed by vegetation rather than running off into the stream channel.

Additional peak flows were measured or estimated for the ephemeral channels of Duncan Creek and Fiddlers Canyon. A crest-stage site was operated on Duncan Creek during 1959-74 and peak flows were measured or estimated for 1960, 1962-64, and 1967-68. A maximum flow of $3,880 \mathrm{ft}^{3} / \mathrm{s}$ on August 19, 1963, was estimated (U.S. Geological Survey, 1964, p. 268). A peak flow of $4,730 \mathrm{ft}^{3} / \mathrm{s}$ in the Fiddlers Canyon drainage basin that resulted from a flash flood on August 17, 1965, was estimated from a field survey (U.S. Geological Survey, 1966, p. 311). Most of these reported peak flows occurred during July through September.

\section{Hydrology of the Ground-Water System}

The ground-water flow system in Cedar Valley comprises many geologic and hydrologic components that are interconnected to various degrees. The groundwater system includes both the unconsolidated basin fill and consolidated rocks in the surrounding mountains. Hydrologic parameters include the spatial distribution and rate of recharge, subsurface inflow from and outflow to adjacent areas, spatial distribution and rate of well withdrawals, and spatial distribution and rate of transpiration from phreatophytes and evaporation from playa surfaces. Previous hydrologic studies of Cedar Valley (Thomas and Taylor, 1946; and Bjorkland and others, 1978) did not examine the ground-water budget in the detail necessary to understand the contribution of various water-budget components. Additional data and new interpretive techniques unavailable during previous studies are used in this report to make estimates of ground-water budget components.

To analyze possible changes in the ground-water system through time, two water budgets were developed during this study. The first budget represents conditions during 1938-49, prior to large-scale ground-water development, and was derived from data presented in Thomas and Taylor (1946) and by applying interpretive techniques to data that represent long-term average conditions. During this period, ground-water levels, groundwater withdrawals, and streamflow in Coal Creek were relatively constant (Burden and others, 2002, fig. 25). The predevelopment budget is representative of a groundwater system without substantial anthropogenic stresses. Water-level changes were the result of differences in annual flows in Coal Creek and there were no widespread ground-water level declines caused by withdrawals. The second budget represents ground-water conditions during 2000. Some of the water-budget components were derived from conditions specific to 2000, whereas some components were derived from long-term average conditions as in the first budget.

\section{Hydrogeology}

Cedar Valley, like most basins in the Great Basin, is a structural, depositional basin that is bounded by normal faults along the west and east margins. The topographic highs that surround Cedar Valley include the Markagunt Plateau on the east, the Harmony Mountains on the southwest, The Three Peaks on the west, and the Black Mountains to the north. Consolidated rocks, where exposed on the west side of the basin, consist of Tertiaryage volcanic and intrusive rocks with uniform lithology. The consolidated rocks exposed in the plateau on the east side of the basin span a greater geologic timeframe and have a more varied lithology than those on the west side of the basin. The structural framework of these is more complex as a result of folding and faulting at the transition from the Basin and Range to the Colorado Plateau Physiographic Province. A complete description of the geology in the study area is presented by Hurlow (2002) and parts of the report that are pertinent to this report are summarized below.

\section{Unconsolidated Basin Fill}

Cedar Valley formed as a graben as a result of displacement along the normal basin-bounding faults during Miocene to Quaternary time (Hurlow, 2002, p. 8). The more complex eastern basin-bounding faults have more displacement than the western faults. This basin asymmetry resulted in thicker alluvial sequences adjacent to the eastern basin-bounding faults (Hurlow, 2002, fig. 10). The alluvial material eroded from the surrounding highlands and deposited in the basin comprises the principal aquifer from which most of the ground water used in the basin is derived. Through the combined use of seismicreflection profiles and a detailed lithologic log, Hurlow (2002, p. 9-18, figs. 7-10) was able to distinguish three layers, faults, and two laterally persistent, angular unconformities within the basin fill. The three layers or units, 
informally designated $\mathrm{A}, \mathrm{B}$, and $\mathrm{C}$, vary in thickness and horizontal extent. The upper unit, A, has the largest areal extent and comprises the youngest deposits. Unit A thins toward the west and thickens toward the faults that define the eastern margin of the structural basin. The maximum thickness of unit A is more than $1,000 \mathrm{ft}$ northwest of Cedar City and more than 1,500 ft north of Enoch (Hurlow, 2002, fig. 10B). The upper part of unit A overlaps these faults and thins toward the eastern margin of the basin. Most of the wells in the center of the valley are completed in unit A and some wells along the basin margins penetrate through unit $\mathrm{A}$ into unit $\mathrm{B}$. Unit $\mathrm{B}$ is the thickest of the three units and like unit $A$, it thins to the west and thickens toward the faults on the east. The maximum thickness of Unit B is more than $1,750 \mathrm{ft}$ in the Rush Lake area (Hurlow, 2002, fig. 10C). The thickness of unit $\mathrm{B}$ east of the faults and in the south part of the basin could not be determined. Unit $C$ is the thinnest of the three units and has a similar geometry to that of unit B. The maximum thickness for all three units is more than 3,500 $\mathrm{ft}$ in the Rush Lake area and is more than $1,000 \mathrm{ft}$ throughout most of the basin (Hurlow, 2002, fig. 10A).

Because of the lack of data specific to Cedar Valley for the conversion of seismic velocities and time profiles to depth, the resultant values for thickness should be considered minimum values (Hurlow, 2002, p. 9). The seismic velocities used in the interpretation were the same for units $\mathrm{A}$ and $\mathrm{B}$ and higher for unit $\mathrm{C}$, thus indicating that unit $\mathrm{C}$ is more compacted than the overlying units. For purposes of the hydrologic study, units A and B are considered to be the principal aquifer. Some degree of consolidation probably exists for unit B in the deepest parts of the basin. Although not shown by Hurlow (2002), the combined thickness of units A and B is more than $1,000 \mathrm{ft}$ throughout much of the basin.

Because of the poor quality of the seismic profiles representing the upper 500-600 ft of basin fill and the lack of detailed lithologic logs along or near the seismic profiles, the near-surface geometry and projections of contacts between the defined units could not be determined and the composition and age of the three units are speculative (Hurlow, 2002, p. 13). The analysis of drillers' logs and examination of near-surface deposits that are presented in Hurlow (2002, p. 21-28, figs. 13-15) help in understanding the composition and spatial distribution of the basin fill where wells are prevalent.

Alluvial-fan deposits are located along the basin margins, with the alluvial fan created by Coal Creek being the most pronounced. These deposits generally are poorly sorted with no defined layering. Toward the distal end of the alluvial-fan deposits, grain size generally decreases and sorting increases. In the center of the basin, fluvial deposits tend to have a finer average grain size and a greater degree of layering. The schematic cross sections (Hurlow, 2002, fig. 15) based on drillers' logs show that in most of the basin, generally medium- to coarse-grained deposits are located along the margins and interfinger with fine-grained deposits in the center of the basin where the upper 25-100 ft generally are finer grained than the underlying deposits. The cross section representative of the northern part of the basin shows a greater prevalence for fine-grained deposits. Because of the inherent imprecision of drillers' logs, any laterally persistent layers of more than $1 \mathrm{mi}$ may be obscured (Hurlow, 2002 , p. 21). Until a more detailed analysis of the unconsolidated basin-fill stratigraphy is completed, finegrained confining layers are assumed to be discontinuous.

\section{Consolidated Rocks}

The amount of water derived from consolidated rocks for municipal use within the Cedar Valley drainage basin is small. In an attempt to better understand the potential for consolidated rocks to be developed for additional water supplies, Hurlow (2002, fig. 23) classified the formations as aquifer or potential aquifer, heterogeneous, or aquitard on the basis of a qualitative evaluation of the known yield of water from wells and springs and the degree of cementation and fracturing within the consolidated-rock formations. Consolidated rocks that are likely or known to yield water to wells include Tertiaryage quartz monzonite and volcanic rocks, and the Jurassic-age Navajo Sandstone.

Tertiary-age quartz monzonite rocks that crop out in The Three Peaks and underlie much of the basin fill along the western margin of the basin north of The Three Peaks have a high to moderate fracture density (Hurlow, 2002, p. 39, fig. 22 and 24, pls. 1 and 2). The small amount of annual precipitation (10-12 in.) where these rocks crop out limits the potential for ground-water development.

The Quichapa Group and the underlying Isom Formation and Needles Range Group compose the Tertiaryage volcanic rocks that crop out in the Harmony Mountains to as far north as Iron Springs Gap and north of The Three Peaks. The Quichapa Group is highly fractured and thus can readily transmit water (Hurlow, 2002, p. 39). The underlying Tertiary-age volcanic rocks are tabular deposits of uniform lithology such that ground-water flow is unlikely to be disrupted by facies variation. These 
rocks continue into the subsurface uninterrupted by major faults and are in contact with the basin fill in the southwestern part of the basin. Some of the existing wells in this area might penetrate these rocks.

The Jurassic-age Navajo Sandstone is known for its ability to yield water to wells throughout much of southwestern Utah because of its primary permeability and secondary fractures (Heilweil and others, 2000, p. 48). The Navajo Sandstone crops out to the east of Cedar City and to the south along the Hurricane Cliffs. Wells have been drilled into the Navajo Sandstone in Coal Creek Canyon east of Cedar City where water was present, but because of caving within the boreholes, these wells were abandoned (Hurlow, 2002, p. 39). North of Cedar City, the sandstone lies beneath the Cretaceous-age Wahweap Sandstone and Straight Cliffs Formation (undivided) and Jurassic-age Carmel Formation, where it is in contact with the lower part of the basin fill (Hurlow, 2002, pl. 2). Because of its depth and structural relation to overlying formations, it is unlikely that the Navajo Sandstone contributes any substantial amount of water to the upper, permeable unconsolidated basin fill.

Hurlow (2002, fig. 23) has classified most of the remaining pre-Tertiary-age consolidated rocks on the east side of the study area as being heterogeneous units. These rocks comprise interlayered sandstone, siltstone, and mudstone with individual layers of limited vertical and lateral extent (Hurlow, 2002, p. 39-41). The hydrologic properties of these formations are poorly known. These formations probably do not contribute substantial amounts of water to the basin fill as any water movement through these formations probably is away from Cedar Valley along east-dipping bedding planes. These formations, however, probably provide much of the base flow to Coal Creek either as spring discharge or as subsurface inflow. Subsurface inflow may occur in limited areas where these rocks dip toward the basin fill such as the area north of Cedar City as shown in cross section B-B' in Hurlow (2002, pl. 2).

\section{Ground-Water Conditions in the Unconsolidated Basin Fill}

Ground water in the unconsolidated basin fill of Cedar Valley occurs under both confined and unconfined conditions depending on depth and location within the unconsolidated basin fill. Unconfined or water-table conditions exist along the basin margins and probably throughout the northern part of the basin. In these areas, the unconsolidated basin fill consists largely of coarse, unsorted sands and gravels intermixed with zones of fine sand and silt. There are no layers of clay or silt that might act as a confining layer (Bjorkland and others, 1978, p. 21).

Ground water is under confined conditions in the center of the basin where zones of permeable material are mixed with discontinuous lenses of relatively impermeable clay or silt. No distinct confining layers have been defined in previous studies. Cross sections of unconsolidated basin fill derived from the analysis of drillers' logs are presented by Hurlow (2002, fig. 15) and show primarily fine-grained deposits with intermixed lenses of medium-grained basin fill. Water in the center of the valley above clay and silt lenses is unconfined.

Water moves from recharge areas along the basin margin through permeable zones to the center of the basin where confining lenses restrict upward movement. The maximum area of artesian flow outlined by Thomas and Taylor (1946, pl. 18) generally has been considered to be the extent of the confined part of the ground-water system in Cedar Valley. As water levels have declined as a result of continued ground-water withdrawals, the present extent under confined conditions in the principal aquifer may be less than that previously defined. If water levels in an area have declined sufficiently so as to be below the confining layer, then ground water above the confining layer is considered to be under perched conditions and ground water below the confining layer may become unconfined. The extent of such conditions is unknown because of the lack of wells completed specifically in either confined or unconfined zones. A more detailed discussion is presented in the "Movement" section of this report.

\section{Aquifer Properties}

Aquifer properties describe the ability of the ground-water system to transmit and store water. Hydraulic conductivity is a function of the porous medium and the fluid and describes the ability of an aquifer to transmit water. Transmissivity is hydraulic conductivity multiplied by the thickness of the aquifer. The ability of an aquifer to store water is defined by the storage coefficient that quantifies the volume of water released from or taken into storage for a given change in water level. Values for the storage coefficient in an unconfined aquifer, also known as specific yield, are orders of magnitude greater than values for storage in a confined aquifer. Values for transmissivity can be determined from single- and multiwell aquifer tests or calculated from specific-capacity data. Transmissivity values estimated from pumping data are representative of the perforated zone of the well and 
not necessarily representative of the entire aquifer thickness. Representative storage-coefficient values can be obtained best from multi-well tests.

A spatial distribution of transmissivity values in the unconsolidated basin fill of Cedar Valley was determined by Bjorklund and others (1978, pl. 2). Plotted data were derived from 5 aquifer tests and 55 wells with specific-capacity data (Bjorklund and others, 1978, p. 22, table 4). Bjorklund and others (1978, p. 23) compared transmissivity values determined by aquifer tests to those calculated from specific-capacity data at several wells. Transmissivity values determined from aquifer tests were 40 to 60 percent greater than those calculated from specific-capacity data. Because transmissivity values determined from aquifer tests were considered more accurate, values determined from specific-capacity data were adjusted.

The highest transmissivity values are in three areas: the alluvial fan in and adjacent to Cedar City, the alluvial fan southwest of Quichapa Lake, and in the area near Rush Lake (Bjorklund and others, 1978, pl. 2). The highest values determined from aquifer tests are located southwest of Quichapa Lake with a reported maximum value of $52,000 \mathrm{ft}^{2} / \mathrm{d}$. Values in the other two high transmissivity areas were determined from specific-capacity data and are greater than $20,000 \mathrm{ft}^{2} / \mathrm{d}$. In the center of the basin, transmissivity values were reported to range from 5,000 to $10,000 \mathrm{ft}^{2} / \mathrm{d}$. From sparse data along the western basin margin, transmissivity values were reported to range from 1,000 to 5,000 $\mathrm{ft}^{2} / \mathrm{d}$ (Bjorklund and others, 1978, pl. 2).

Since the study by Bjorklund and others (1978), numerous irrigation, domestic, and municipal-supply wells have been completed in Cedar Valley. Aquifer tests have been completed on new wells used for municipal or residential supply to meet wellhead-protection requirements, and specific-capacity data for many of the irrigation and domestic wells have been reported on drillers' logs. On the basis of these new data and revision of specific-capacity data used by Bjorklund and others (1977, 1978), Hurlow (2002, fig. 21) updated the spatial distribution for transmissivity values. This distribution is similar to the one reported by Bjorklund and others (1978, pl. 2) but is more complex because of increased data density in some areas. Areas of high transmissivity values remain the same except along the eastern margin where additional data have resulted in more definition. The higher transmissivity values appear in alluvial fans created by the drainages of Coal and Shirts Creeks and in the area south of Enoch (Hurlow, 2002, fig. 21).
Aquifer tests and specific-capacity data used to estimate transmissivity values are obtained from wells that typically do not penetrate the entire aquifer. Data that define the degree of partial penetration are lacking. The results of these analyses, therefore, are not necessarily an accurate representation of transmissivity. These values, however, can be used to estimate probable ranges of hydraulic conductivity for similar sediment types.

Estimates of hydraulic conductivity were determined from transmissivity values that were derived from aquifer tests and specific-capacity data reported in previous studies (Bjorklund and others, 1977, table 1; and 1978, table 4) (Hurlow, 2002, tables 1 and 2). Ignoring the effects of partial penetration, hydraulic conductivity is estimated by dividing the transmissivity value by the total perforated interval of the well. In Cedar Valley, many of the production wells are perforated over large intervals that may contain a considerable extent of lowerpermeability zones. For these wells, transmissivity values are representative only of the higher permeability zones and estimated hydraulic-conductivity values were adjusted according to the total thickness of these zones. Permeable zones may be composed of sand, gravel, cobbles, boulders, or a combination of these sediment types. Alluvial-fan deposits along the eastern and southwestern margins of the basin tend to have a larger average grain size and less sorting. Unconsolidated basin fill along the western margin and in the center of the basin tends to have a smaller average grain size and a greater degree of sorting (Hurlow, 2002, p. 33). Estimated hydraulic-conductivity values ranged from $5 \mathrm{ft} / \mathrm{d}$ to $180 \mathrm{ft} / \mathrm{d}$. The wide range of values typifies the variability in sediment type and degree of sorting in coarse deposits throughout the basin. Sand and sand/gravel mixtures, which are the predominant coarse material in the center of the basin, will tend to have hydraulic-conductivity values toward the low end of the range; whereas zones of gravel and cobbles, especially in the alluvial-fan deposits, will tend to have values toward the upper end. Most of the estimated hydraulic-conductivity values for coarse-grained sediment ranged from $10 \mathrm{ft} / \mathrm{d}$ to $60 \mathrm{ft} / \mathrm{d}$.

A general distribution of permeable sediments was determined for most of the basin. On the basis of information reported in drillers' logs, the ratio of permeable, coarse-grained to fine-grained intervals can be determined for each well. This ratio, expressed in percentage of coarse material, was determined for all drillers' logs and averaged for each square-mile section. Ranges for the percentage of coarse-grained material are shown in figure 4. In sections where no drillers' logs are available, percentages were extrapolated from the nearest section(s) 


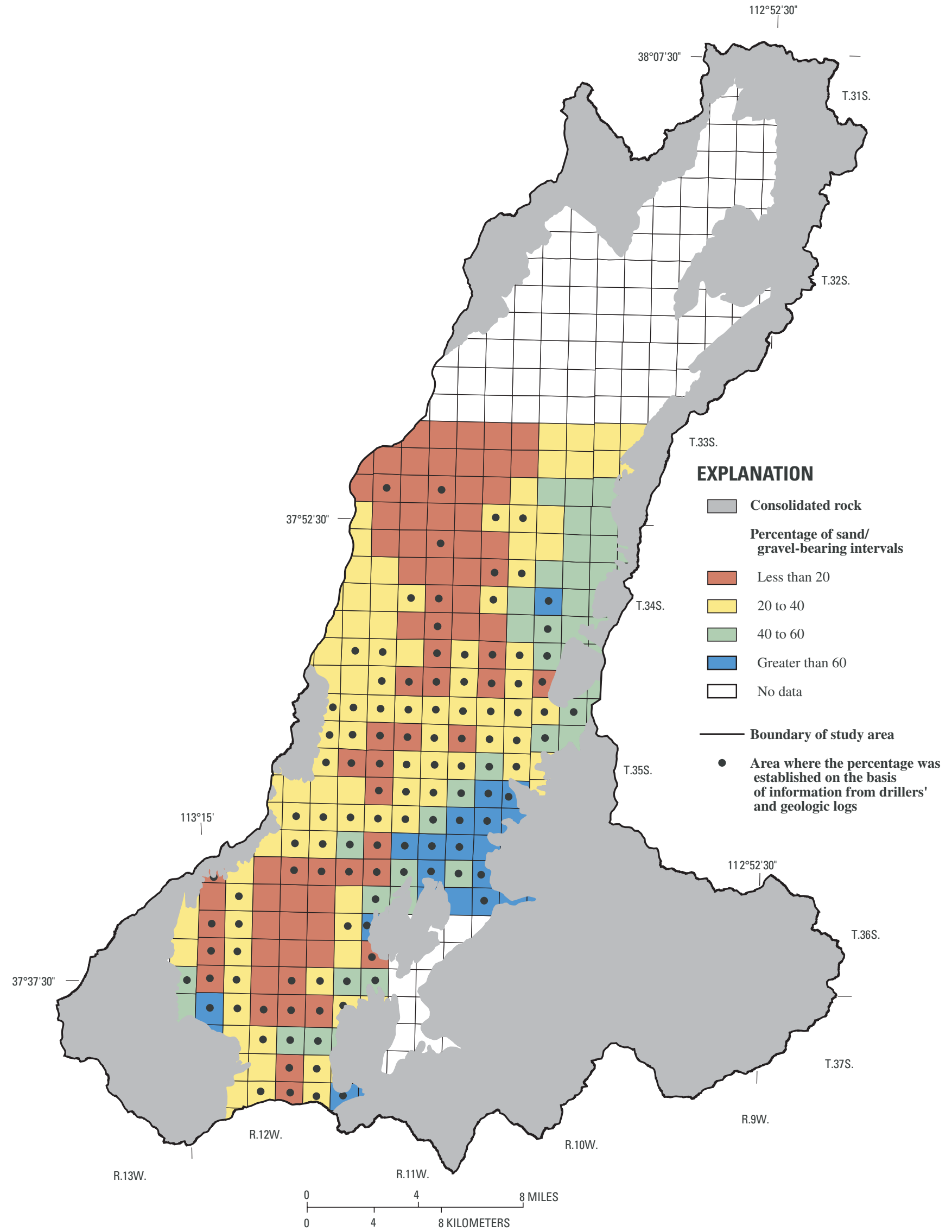

Figure 4. Estimated percentage of sand/gravel-bearing intervals in the unconsolidated basin fill, Cedar Valley, Iron County, Utah. 
with a value. No percentages are shown in the northern part of the basin because wells have not been drilled in this area.

A general range of transmissivity values can be derived by using estimates of hydraulic conductivity, percentage of aquifer that comprises permeable material, and aquifer thickness. Typical values for hydraulic conductivity of the coarse-grained material in the center of the basin range from 5 to $20 \mathrm{ft} / \mathrm{d}$, whereas typical values for coarser alluvial-fan deposits range from 30 to $60 \mathrm{ft} / \mathrm{d}$. Estimates for transmissivity range from about $1,200 \mathrm{ft}^{2} / \mathrm{d}$ in the Quichapa Lake area to $90,000 \mathrm{ft}^{2} / \mathrm{d}$ in the Coal Creek alluvial fan. The maximum value assumes that 100 percent of the aquifer thickness in this area comprises gravel and cobbles with a hydraulic conductivity of $180 \mathrm{ft} / \mathrm{d}$.

No aquifer tests were completed during this study or previous studies that determined vertical hydraulicconductivity values. Most existing wells are screened or perforated over large intervals; an aquifer test that is designed to determine vertical hydraulic conductivity would require the completion of observation wells with screened intervals above the screened interval of the pumping well. Vertical hydraulic-conductivity values are important for understanding the movement of water from recharge on the surface to the perforated intervals of production wells. No continuous confining layer has been identified in Cedar Valley and, therefore, a vertical hydraulic-conductivity value determined from an aquifer test at one location might not be applicable at another location. Vertical hydraulic-conductivity values depend on sediment type and grain shape. Coarse-grained material with a rounded grain shape will have vertical hydraulic-conductivity values similar to those in the horizontal direction. As mentioned previously, hydraulic-conductivity values generally range from 10 to $60 \mathrm{ft} / \mathrm{d}$. Assuming vertical hydraulic-conductivity values for coarse-grained material are no lower than one order of magnitude less, minimum vertical hydraulic-conductivity values would be 1 to $6 \mathrm{ft} / \mathrm{d}$. Conversely, fine-grained material, such as clay and silt, likely will have a flat grain shape, which generally will be arranged in a subparallel manner. With this grain orientation, the porous material would have a much greater ability to transmit water in a horizontal direction and, therefore, vertical hydraulic conductivity might be one to two orders of magnitude less than horizontal hydraulic conductivity. Hydraulic-conductivity values for clay and silt can range from $1 \times 10^{-6}$ to $1 \mathrm{ft} / \mathrm{d}$ (extrapolated from Domenico and Schwartz, 1990, table 3.2). Vertical hydraulic-conductivity values, therefore, may range from $1 \times 10^{-8}$ to $0.1 \mathrm{ft} / \mathrm{d}$.
Values for storage reported by Bjorklund and others $(1978$, table 4$)$ were determined from a limited number of multi-well aquifer tests. Where unconfined ground-water conditions exist, water-level declines in observation wells were insufficient during the tests to determine storage values. Specific-yield values of 0.2 were estimated based on effective porosity and reported by Bjorklund and others (1978, table 4). In areas where confined or semi-confined ground-water conditions exist, storage-coefficient values determined from multi-well aquifer tests ranged from 0.0005 to 0.013 . Values near the upper end of this range are representative of semi-confined ground-water conditions (Lohman, 1972, p. 8).

\section{Movement}

Ground water flows from a position of high hydraulic head to one of lower hydraulic head. In map view, the hydraulic head of ground water is represented by contours of the potentiometric surface. The direction of ground-water flow is perpendicular to the contours. The amount of change in hydraulic head divided by a specified distance along the direction of ground-water flow is known as the hydraulic gradient. Similarly, the vertical hydraulic gradient is the amount of change in hydraulic head divided by the vertical distance between the zones for which representative hydraulic heads were measured. The vertical direction of ground-water flow can be upward if the hydraulic head in the deep zone is higher than the hydraulic head in the shallow zone.

Ground water in Cedar Valley generally flows from primary recharge areas along the eastern margin of the basin, mostly where Coal Creek enters the basin, to areas of discharge or subsurface outflow in the center and west side of the basin. The potentiometric surface for March 2000 shown in figure 5 is very similar to the potentiometric surface for March 1974 shown in Bjorklund and others (1978, pl. 5). The direction of ground-water flow has remained the same despite lower water levels in areas of large ground-water withdrawals. Ground water flows from the recharge areas near Coal Creek to three discharge areas at Rush Lake and Mud Springs Canyon, Iron Springs Gap, and Quichapa Lake. Flow toward The Three Peaks indicates that no substantial recharge occurs from The Three Peaks. 


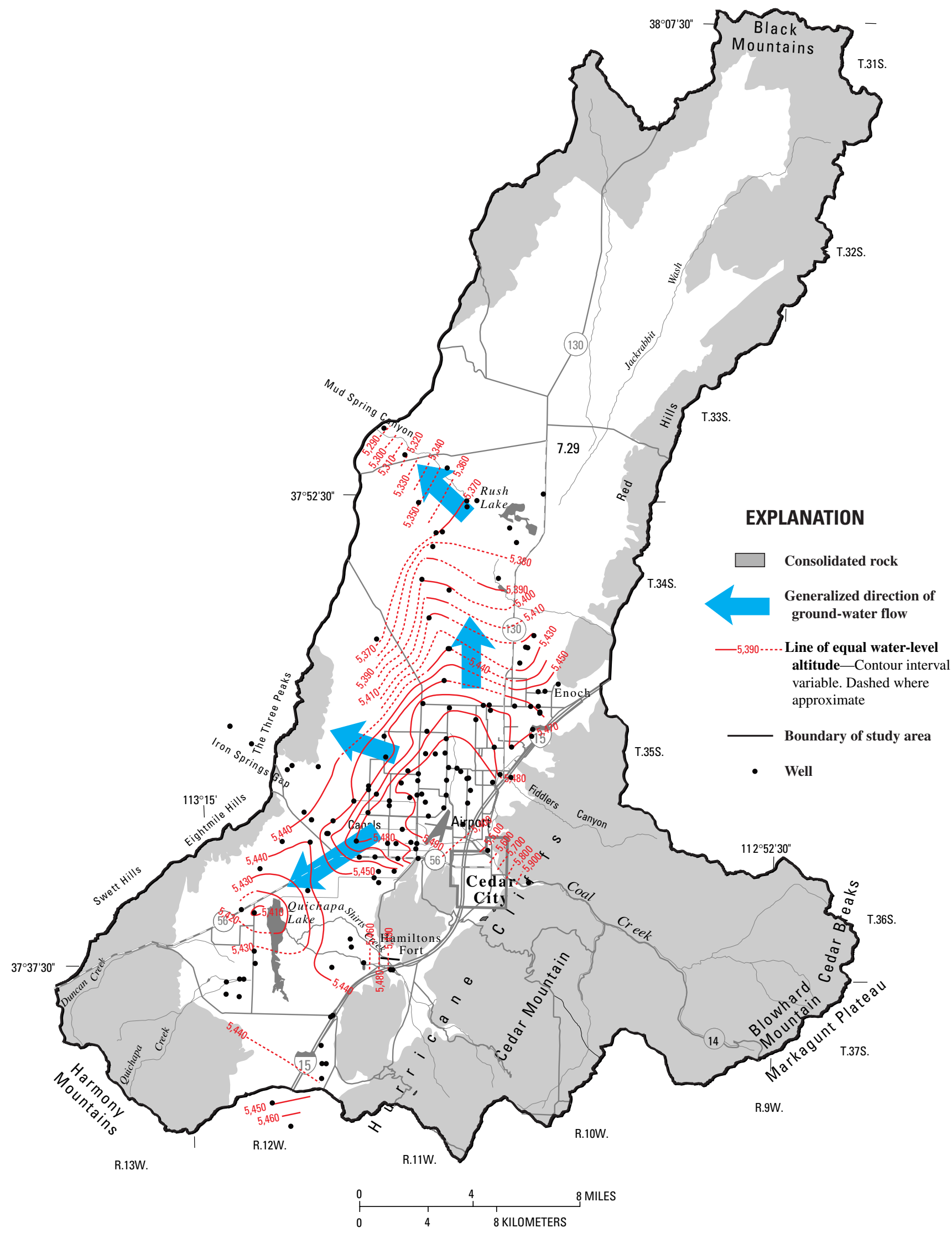

Figure 5. Approximate potentiometric surface for the unconsolidated basin fill, March 2000, Cedar Valley, Iron County, Utah. 
Some of the water that recharges the aquifer in the area of the Coal Creek alluvial fan flows south to the Quichapa Lake playa and municipal wells in the area. Some ground-water flow comes into this area from the east where it enters from the Shirts Creek drainage, and from the south where subsurface flow has been induced as a result of ground-water withdrawal. In the past, some ground-water flow came from the southwest near the Harmony Mountains as shown by the potentiometric surface of Bjorklund and others (1978, pl. 5). This component of ground-water flow is less obvious at the present time because of lower ground-water levels that are a result ground-water withdrawals.

Contours shown on the potentiometric surface map by Thomas and Taylor (1946, pl. 14) indicate that the eastern basin-bounding faults may influence the hydraulic gradient and direction in Cedar Valley. Bjorklund and others (1978, p. 26) reported that similar faults in Parowan Valley did not affect water-level declines in observation wells on opposite sides of a fault during an aquifer test. No water-level, chemical, or aquifer-test data that would indicate restricted ground-water flow by the eastern basin-bounding faults were collected during this study.

Water levels are not available north of Rush Lake, and directions of ground-water flow in this area cannot be determined. It is likely, however, that ground water moves from recharge areas in the Black Mountains south to Rush Lake, generally following the valley topography. Because little ground-water withdrawal occurs in this area, a long-term steady-state condition probably exists. Recharge from precipitation on unconsolidated basin fill and consolidated rock probably equals discharge by evapotranspiration and some subsurface outflow through Mud Spring Canyon.

The vertical component of ground-water flow in Cedar Valley is poorly understood because of a lack of water-level data representative of discrete zones within the unconsolidated basin fill. Most wells are perforated over large intervals and measured water levels represent an average value for the principal aquifer. Also, few wells are completed in shallow zones because of low yield and high dissolved-solids concentration. In the primary recharge area along the eastern margin of the basin where the unconsolidated basin fill is generally coarser and poorly sorted, ground water is unconfined and the vertical hydraulic gradient is downward. A similar condition probably exists in the southwestern part of the basin adjacent to the Harmony Mountains.
Throughout much of the center of the basin, the vertical hydraulic gradient and, therefore, the potential for ground-water flow, historically has been upward. Thomas and Taylor (1946, p. 97) reported water levels at eight pairs of shallow and deep wells, located from Rush Lake in the north to Quichapa Lake in the south, range from about $2 \mathrm{ft}$ to $9 \mathrm{ft}$ higher in the deep wells as compared to the associated shallow wells. Because the perforated intervals for the wells are unknown, the vertical hydraulic gradient cannot be calculated. Thomas and Taylor (1946, pl. 18) show the spatial extent of confined conditions that cover $50 \mathrm{mi}^{2}$ in the center of the basin from northwest of Enoch to south of Quichapa Lake. Flowing wells reported for September 1939, however, are shown only in areas west of Enoch and surrounding Quichapa Lake. By 1975, ground-water withdrawals had lowered water levels to the extent that no wells were reported to be flowing (Bjorklund and others, 1978, p. 19). They concluded that confined conditions continued to exist in this area, but the confined pressures were not sufficient for flowing wells.

During this study, shallow wells were completed adjacent to deeper irrigation wells at two locations within the area of confined conditions to examine the present potential for vertical ground-water flow. Wells (C-3511)14bac-1 and -2 are located just west of Enoch. Well (C-35-11)14bac-1 is perforated from 200-501 ft and well (C-35-11)14bac-2 is perforated from 46-56 ft (Howells and others, 2002, p. 7). The water level in the shallow well was $3 \mathrm{ft}$ higher than the level in the deep well prior to the irrigation season of 2001 (Howells and others, 2002, p. 21). By May 2001, the water level in the shallow well was unchanged whereas the level in the unused deep well had declined by $17 \mathrm{ft}$. At this location the potential for ground-water flow is downward and increases during the irrigation season. Wells (C-35-12)36caa-1 and -2 are located about 4 mi northwest of Cedar City. Well (C-3512)36caa- 1 is perforated from $214-704 \mathrm{ft}$ and well (C-3512)36caa- 2 is perforated from $65-75 \mathrm{ft}$ (Howells and others, 2002, p. 7). The water level in the shallow well was more than $37 \mathrm{ft}$ higher than the level in the deep irrigation well prior to the irrigation season in 2001 (Howells and others, 2002, p. 35). During the irrigation season, the water level in the shallow well rose slightly. The rise indicates probable recharge from irrigation. It is possible water levels in the shallow well would decline in response to pumping the deep well if recharge from irrigation was not occurring, or that the rise would be greater if pumping was not occurring. 
Data collected during this study at the nested wells indicate that the long-term trend of decreasing water levels may result in a decrease of the areal extent of confined conditions for the principal aquifer and an increased potential for downward movement from the overlying shallow zones. More shallow monitoring wells located adjacent to existing deep wells with known perforated intervals are needed to better understand current conditions for potential vertical ground-water flow.

\section{Recharge}

Ground-water recharge to unconsolidated basin-fill aquifers in the Great Basin is derived from precipitation, mostly as winter precipitation that is stored in the form of snowpack in the adjacent mountains (Harrill and Prudic, 1998, p. A23). Recharge processes are complex and not fully understood because of a lack of ground-water data in recharge areas. Recharge from snowmelt is dependent upon the hydraulic properties of consolidated-rock units in the adjacent mountains and the stratigraphic and structural relation between different consolidated-rock units.

Recharge to basin fill from melting snowpack may occur either through the mountain block and subsequent subsurface inflow into the unconsolidated basin fill or as seepage from stream runoff flowing over alluvial deposits adjacent to the mountain block. Streamflow that does not seep into the subsurface is available for irrigation and can be diverted from streams entering the basin. In Cedar Valley, recharge to the unconsolidated basin fill is primarily by seepage from streams, seepage from unconsumed irrigation water, infiltration from direct precipitation, and subsurface inflow from consolidated rock and adjacent areas (table 2).

\section{Seepage from Streams}

Despite coarse material in the alluvial fan, seepage from Coal Creek in this area is less than would be expected. Because of deposition of fine material along the stream channel, Thomas and Taylor (1946, p. 99) report no appreciable seepage losses along the $2.25-\mathrm{mi}$ reach downstream from USGS streamflow-gaging station 10242000. Seepage measurements that were made during this study and reported in Howells and others (2002, table 5 ) support this conclusion. Measured gains and losses along this reach were minimal and within measurement error. Measurements made along the reach that coincides with the alluvial fan generally show negligible losses except for the first segment where measurements indicate a possible 6 percent loss. Measurements made along the ditch that flows toward Quichapa Lake indicate possible losses of 7 to as much as 20 percent. On the basis of these measurements, seepage from Coal Creek, Shirts Creek, and large, unlined canals and ditches during the summer months (mid-March through mid-October) was estimated to be, on average, about 10 percent of the flow.

Deposition of fine-grained material on the streambed and the straining of colloidal material in the hyporheic zone, where water flows through the alluvial material just beneath the streambed surface, can result in less seepage than expected. In the Milford area, just north of Cedar Valley, Mower and Cordova $(1974$, p. 18) reported that as much as 34 percent of the water diverted from the Beaver River infiltrates to the ground-water system as it flows across the alluvial fan. Much of the fine-grained suspended material in the Beaver River is deposited upstream in Rocky Ford Reservoir. Unlike the Beaver River, streamflow in Coal Creek may contain large amounts of fine-grained material after thunderstorms that occur in the upper reaches of the drainage. This periodic deposition of fine-grained material on the streambed or within the underlying hyporheic zone can decrease seepage during periods of low to near-normal streamflow. During periods of greater-than-normal streamflow, such as during spring snowmelt runoff, the fine-grained material can be redeposited toward the center of the basin. Under these conditions, seepage on the alluvial fan may be considerably more than the estimated 10 percent.

During the winter (mid-October to mid-March), water in Coal Creek flows through canals and ditches with much of the water being transported to Quichapa Lake in recent years. Because evapotranspiration is small during the winter and no surface water exits the basin, about 80-90 percent of the streamflow in Coal Creek is assumed to recharge the ground-water system.

A small amount of streamflow is present in Shirts Creek, the only other perennial stream in the study area. The drainage area of Shirts Creek $\left(18.7 \mathrm{mi}^{2}\right)$ is not as large as that of Coal Creek $\left(80.9 \mathrm{mi}^{2}\right)$, and streamflow in Shirts Creek is disproportionally smaller than streamflow in Coal Creek. During 2000, total streamflow in Shirts Creek was about 325 acre-ft, which was estimated from a weighted average of instantaneous measurements reported in Herbert and others (2001, p. 347). Recharge from Shirts Creek was estimated to be 200 acre-ft, which consists of seepage from applied irrigation water and from the stream channel. Other flows might occur in ephemeral drainages primarily during runoff from thunderstorms but also during runoff from exceptionally large 
Table 2. Ground-water budget prior to large-scale development and for 2000, Cedar Valley, Iron County, Utah

\begin{tabular}{lrr}
\hline & $\begin{array}{c}\text { Prior to development } \\
\text { (acre-feet) }\end{array}$ & $\begin{array}{c}\mathbf{2 0 0 0} \\
\text { (acre-feet) }\end{array}$ \\
\hline Recharge & & \\
Recharge from irrigation with ground water & 6,600 & $7,100-8,600$ \\
Seepage from streams and major irrigation canals & $5,100-5,500$ & $4,700-5,100$ \\
Recharge from irrigation with surface water & 9,400 & 4,900 \\
Recharge from land application of waste-water effluent & negligible & 1,500 \\
Recharge from irrigation of lawns and gardens & negligible & $600-1,000$ \\
Precipitation on unconsolidated basin fill ${ }^{1}$ & 10,300 & 10,300 \\
Bedrock inflow from surrounding hills and mountains ${ }^{2}$ & 9,900 & 9,900 \\
Subsurface inflow & $2,000-5,000$ & 2,000 \\
Total recharge (rounded) & $43,000-47,000$ & \\
Discharge & & 3,000 \\
Evapotranspiration & 22,000 & 336,000 \\
Wells & 13,200 & negligible \\
Springs & 4,300 & 1,000 \\
Subsurface outflow & 1,000 & 40,000 \\
Total discharge (rounded) & 40,000 & \\
T2,200 acre-feet per year occur north of Rush Lake. & & \\
2 2,900 acre-feet per year occur north of Rush Lake. & &
\end{tabular}

amounts of snowmelt. Because of the infrequent flow and small area of stream channels, recharge from ephemeral drainages throughout the basin was assumed to be negligible.

By using the percentage estimates previously listed and the recharge estimate for Shirts Creek, the average seepage loss from streams and large ditches representative of the period prior to large-scale ground-water development (1938-49) is estimated to be 5,100 to 5,500 acreft. Streamflow data for Coal Creek are incomplete for 1938 and, therefore, average seepage was determined for 1939-49. The estimated seepage for 2000 is 4,700 to 5,100 acre-ft.

\section{Seepage from Irrigation Water}

Recharge from seepage of unconsumed irrigation water is a large component of the ground-water budget for Cedar Valley. Recharge from irrigation is water in excess of the amount needed for plant consumptive use and evaporation. This water seeps through the unsaturated zone beyond plant roots until it reaches the saturated zone. Seepage from unconsumed irrigation water was estimated as a percentage of both ground water with- drawn from irrigation wells and applied surface water that is either flooded onto fields or pumped from ditches and applied through sprinkler systems.

In a study to quantify recharge from applied irrigation water, Susong (1995) measured soil-moisture profiles in flood- and sprinkler-irrigated fields and evapotranspiration in the Milford area located about 35 mi north of Cedar City. These data were used in unsaturated-flow model simulations to determine recharge. Susong (1995, table 3) reported that recharge from unconsumed irrigation water ranged from about 50 to 57 percent for flood-irrigated fields and from about 8 to 14 percent for center-pivot, sprinkler-irrigated fields during 1992-93. Just as these percentages varied over the 2 years of data collection, conditions in other years may produce values outside of these ranges. Factors such as antecedent soil moisture prior to the irrigation season and amount of precipitation during the irrigation season can influence the amount of recharge.

Recharge from irrigation with ground water is dependent upon the amount of water applied and method of application. During the predevelopment period of 1938-49, flood irrigation was common and seepage from applied water is estimated to be 50 percent of the withdrawal for irrigation, or 6,600 acre-ft/yr. Although some ground water for irrigation in 2000 was applied by 
center-pivot sprinklers and flood irrigation, most of the water was applied by line sprinklers. Line sprinklers are not as efficient as center-pivot sprinklers in water application and, therefore, recharge from this method was assumed to be 30 percent. More ground water was applied through center-pivot sprinklers than by flood irrigation; therefore, recharge is estimated to be about 25 to 30 percent of applied ground water. During 2000, about 28,500 acre-ft of water was withdrawn by wells for irrigation (Burden and others, 2001, table 2) and recharge from ground-water irrigation was estimated to be $7,100-$ 8,600 acre-ft.

Recharge from irrigation with surface water is more complex. During mid-March through mid-October, water from Coal Creek is diverted for irrigation through a complex and extensive system of canals and ditches. Because the system of small distribution ditches is extensive and would be difficult to measure, any loss from these ditches is included with estimates of seepage from unconsumed irrigation water. The extent of the distribution system and irrigated lands prior to large-scale ground-water development is unknown. All available surface water, however, was used and it is assumed that the same estimated percentages would be applicable.

Because seepage losses from streams and large canals decrease the amount of water available for application, this amount needs to be subtracted from available water. The average streamflow during the period prior to development was about 21,000 acre-ft. After subtracting stream losses, 18,900 acre-ft was available for flood irrigation. Seepage from unconsumed irrigation water is assumed to be 50 percent or about 9,400 acre-ft. During the summer of 2000, about 13,500 acre-ft of water entered the basin from Coal Creek. Recharge from seepage losses in Coal Creek and large canals was estimated to be 1,350 acre-ft. The remaining 12,150 acre-ft of water was applied to crops by flood irrigation or pumping from ditches into line sprinklers. Accounting for the two methods for surface-water application, seepage from unconsumed irrigation water was estimated to be 40 percent or about 4,900 acre-ft.

Recharge from the application of effluent from the waste-water treatment facility to irrigated fields during the summer and open ground during the non-growing months is substantial. Prior to construction of a wastewater treatment facility, waste water was applied to open land southeast of the airport (Joe Melling, City Manager, Cedar City, oral commun., 2002) where it could evaporate or seep into the subsurface. The first waste-water treatment facility in Cedar City was located just northeast of the airport and operated from 1976 to the beginning of
1996. Effluent from this facility was diverted into ditches and applied to irrigated fields (Joe Melling, City Manager, Cedar City, oral commun., 2002). No data are available to estimate seepage from effluent prior to 1996. Because population was small during the years prior to large-scale development, this form of recharge is assumed to be negligible in the 1938-49 budget (table 2). From 1996 to 2002, a new facility treated waste water from Cedar City and Enoch, and the remaining residential and commercial properties used septic systems. Recharge from waste-water treatment facility effluent was estimated to be 1,500 acre-ft during 2000. Monthly influent data were obtained for 1996-2000 (Darrell Olmsted, Manager of Cedar City waste-water treatment plant, written commun., 2002). Influent was assumed to equal effluent for the calculation. From the beginning of April through September, effluent was assumed to be applied to irrigated fields by flood irrigation, of which 50 percent was estimated to seep into the subsurface. During the remaining months, all effluent was applied to open rangeland, of which 80 percent was estimated to seep into the subsurface because evapotranspiration was less.

Recharge from water application on lawns and gardens within municipalities was estimated by comparing the difference in water consumption between winter and summer months. An average for water consumed per month during January through March and October through December 2000, was determined. This average was subtracted from the water consumed for each month during April through September. The excess water was assumed to be applied to lawns and gardens, of which 15 to 25 percent was assumed to seep into the subsurface. Through this calculation, recharge from application of water to lawns and gardens in Cedar City and Enoch was estimated to be 600 to 1,000 acre-ft during 2000 .

\section{Precipitation}

Recharge from infiltration of direct precipitation on the unconsolidated basin fill was estimated by using a method developed for the Great Basin. In a summary report of the Great Basin Regional Aquifer-System Analysis study, Harrill and Prudic (1998, p. A23-A25) described an analysis in which a regression equation was developed by comparing estimated recharge to average annual precipitation volume where the rate exceeded 8 in/yr in studies throughout the Great Basin. In these studies, recharge was estimated by using some form of the Maxey-Eakin method (Maxey and Eakin, 1949). The Maxey-Eakin method, commonly used in Utah and Nevada, estimates recharge as a percentage of the volume 
of precipitation falling within specified ranges of precipitation within the study area. A higher percentage of precipitation becomes recharge in areas with higher precipitation. The resultant volumes are added to determine total recharge for the study area. The regression equation (Harrill and Prudic, 1998, p. A25) for estimating recharge with the Maxey-Eakin method is:

$$
\log Q_{r}=-1.74+1.10 \log P_{P>8}
$$

where:

$$
\begin{aligned}
Q_{r} & =\text { recharge, in acre- } \mathrm{ft} / \mathrm{yr} ; \text { and } \\
P_{P>8} & =\text { total annual volume of precipitation, in } \\
& \text { acre- } \mathrm{ft} / \mathrm{yr}, \text { where average annual precipita- } \\
& \text { tion exceeds } 8 \text { in. }
\end{aligned}
$$

The regression equation could be applied throughout Cedar Valley because the 1961-90 average annual precipitation on the unconsolidated basin fill ranges from a low of less than $11 \mathrm{in} / \mathrm{yr}$ to about $16 \mathrm{in} / \mathrm{yr}$ in the south end of the basin (Utah Climate Center, 1996). The total annual volume of precipitation (about 170,000 acre-ft/yr) was calculated by multiplying the area between pairs of precipitation contours by the average precipitation for the paired contours. Recharge from direct precipitation on the unconsolidated basin fill was estimated to be about $10,300 \mathrm{acre}-\mathrm{ft} / \mathrm{yr}$, of which 2,200 acre-ft/yr that is derived from precipitation north of Rush Lake does not contribute to the area of primary pumping in the center of the basin. These estimates represent a long-term average and are assumed to be valid for the period prior to large-scale ground-water development and for 2000. The MaxeyEakin method and the regression (eq. 2) estimate longterm average recharge and might not be applicable on a yearly basis. It is likely that years with greater-than-average precipitation provide the most recharge (Flint and others, U.S. Geological Survey, written commun., 2001). Years with near-average precipitation probably provide less-than-average recharge.

The estimate of 10,300 acre-ft/yr for average recharge from infiltration of precipitation on unconsolidated basin fill, which is based on the Maxey-Eakin method, should be considered a maximum value. The Maxey-Eakin method was developed for mountainous areas and does not account for water storage in soil moisture. Net infiltration models account for soil moisture and subsequent loss of soil moisture through evapotranspiration. Net infiltration is flow rate at a depth where evapotranspiration no longer affects the downward movement of water. For most locations, net infiltration eventually becomes recharge (Hevesi and others, 2002, p. 9). In the Death Valley area, Hevesi and others (2002, p. 15) esti- mated the depth of the root zone in alluvial fan, basin, playa, or channel areas, to be about $20 \mathrm{ft}$. Infiltration must first fill soil moisture to this depth before it becomes net infiltration or recharge. Hevesi and others (2002, p. 21) determined that no recharge occurs on these areas throughout the Death Valley area, including higher-altitude areas with more than $8 \mathrm{in} / \mathrm{yr}$ precipitation.

Preliminary estimates by Alan Flint (U.S. Geological Survey, written commun., 2004) indicate that recharge in low-altitude basin-fill areas of Tooele and Utah Valleys in northern Utah is less than estimated using the Maxey-Eakin method.

\section{Subsurface Inflow}

Recharge from subsurface inflow into the unconsolidated basin fill from mountain blocks that surround Cedar Valley was estimated by using the regression equation (eq. 2) described previously. The surrounding mountain blocks were divided into 14 separate areas (fig. 6) and were given informal names that are based on an existing nearby geographic name. Recharge estimates for each area (except for the Coal Creek drainage) are presented in table 3 . The areas were delineated primarily on the basis of surface-water drainage area and topography. In areas where rock types and geologic framework are similar, more than one surface-water drainage basin may be combined into a single area.

Application of the regression equation includes volumetric precipitation but does not consider local geologic factors. Without actual supporting data, applying geologic factors to recharge estimates for each of the areas in this study can be subjective. In the Coal Creek drainage, layered consolidated-rock formations generally dip to the east. For this reason, any water that seeps into these formations, for the most part, is assumed to travel down dip and discharge into Coal Creek and its tributary drainages where they intersect. Recharge to consolidated rock in this area is assumed to be the source for base flow in Coal Creek and the Coal Creek area shown in figure 6 is not included as an area that contributes recharge from consolidated rock. The unconsolidated basin fill and consolidated rock along the eastern margin are thought to be hydrologically connected despite the presence of prominent faults, and the flow across the faults may be greater where more permeable consolidated rocks are adjacent to the unconsolidated basin fill (Hurlow, 2002, p. 33).

In the Harmony Mountains along the southwestern margin of the basin, highly fractured Tertiary-age volcanic rocks crop out (Hurlow, 2002, pl. 1). These rocks probably continue beneath the unconsolidated basin fill 


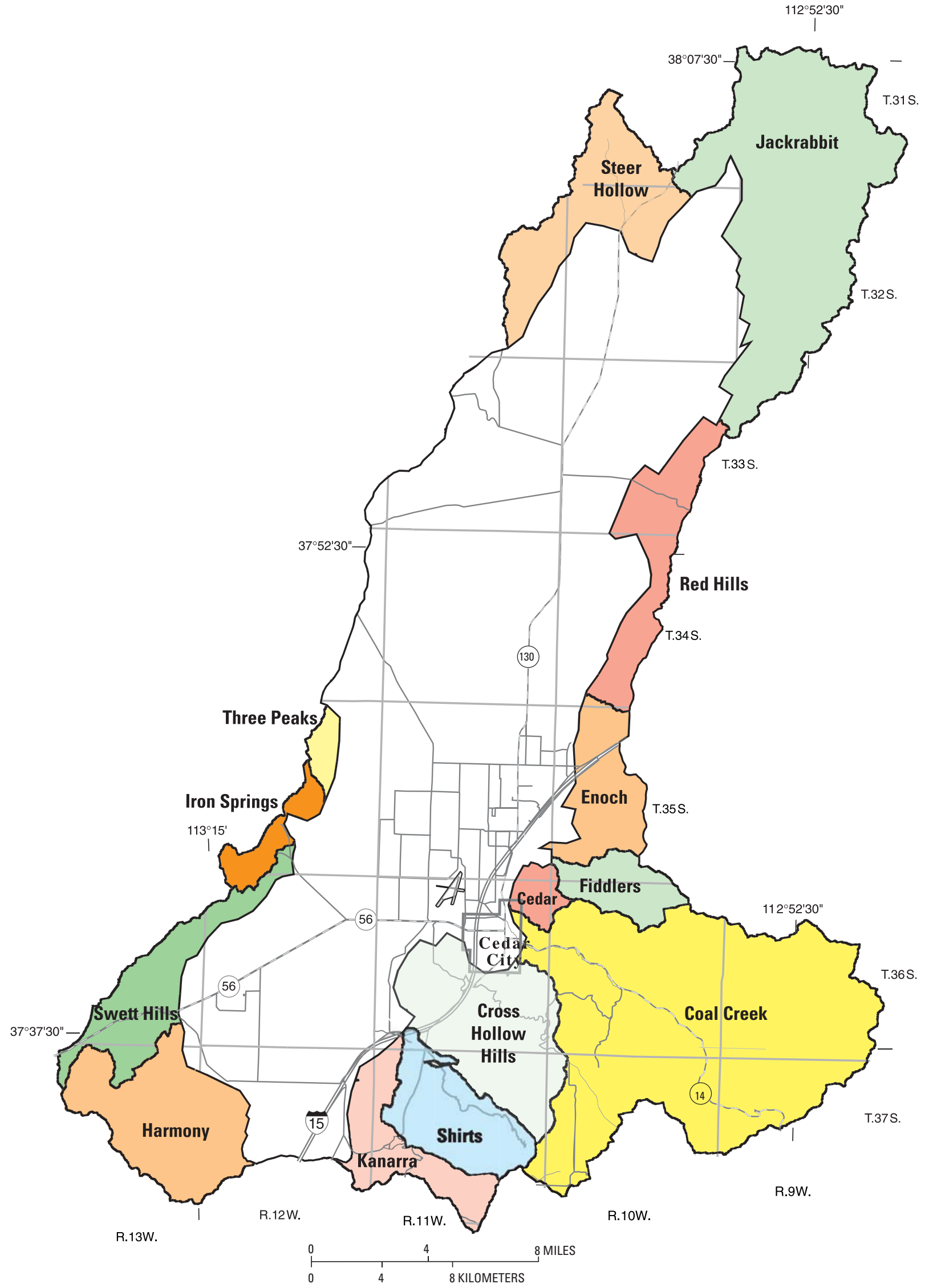

Figure 6. Areas of estimated subsurface inflow from adjacent consolidated rock to the unconsolidated basin fill, Cedar Valley, Iron County, Utah. 
Table 3. Average annual precipitation and recharge for contributing areas, Cedar Valley, Iron County, Utah

[Recharge, $\log$ Recharge $=-1.74+1.10 x \log \left(\right.$ Precipitation $\left._{\text {Precipitation }>8 \text { inches per year }}\right)$, Harrill and Prudic, 1998, p. A25]

\begin{tabular}{|c|c|c|c|}
\hline Contributing area ${ }^{1}$ & $\begin{array}{c}\text { Area } \\
\text { (acres) }\end{array}$ & $\begin{array}{c}\text { Precipitation } \\
\text { (acre-feet per year) }\end{array}$ & $\begin{array}{c}\text { Recharge } \\
\text { (acre-feet per year, rounded) }\end{array}$ \\
\hline Red Hills & 13,520 & 13,090 & 600 \\
\hline Jackrabbit and Steer Hollow & 47,570 & 53,900 & 2,900 \\
\hline Three Peaks and Iron Springs & 4,480 & 4,850 & 200 \\
\hline Swett Hills & 9,490 & 13,290 & 600 \\
\hline Harmony & 14,460 & 24,260 & 1,200 \\
\hline Kanarra & 7,490 & 14,320 & 700 \\
\hline Shirts & 9,230 & 17,860 & 900 \\
\hline Cross Hollow Hills & 16,070 & 24,620 & 1,200 \\
\hline Cedar & 2,030 & 2,080 & 100 \\
\hline Fiddlers and Enoch & 23,910 & 29,120 & 1,500 \\
\hline Total (rounded) & 148,000 & 197,000 & 9,900 \\
\hline
\end{tabular}

${ }^{1}$ Does not include the Coal Creek area shown in figure 6.

without disruption by faults and with a more gently sloping contact between consolidated rock and unconsolidated basin fill (Hurlow, 2002, p. 39). Similar geologic conditions exist in the Swett Hills and The Three Peaks along the western margin of the basin. Precipitation is less because of lower altitudes than in the Harmony Mountains, and estimated recharge to the unconsolidated basin fill is markedly less. This is substantiated by the lack of a hydraulic gradient from these mountain blocks toward the center of the basin as discussed in the "Movement" section of this report.

Subsurface inflow from adjacent areas and beneath Coal Creek is difficult to estimate because data are sparse. Subsurface inflow may occur near Enoch where ground water might exit Parowan Valley, located to the northeast; beneath Coal Creek where it enters the basin; and along the southern boundary.

Subsurface inflow can be estimated by using Darcy's Law as defined by the equation:

$$
Q=K I A
$$

where:

$Q=$ volumetric ground-water flow $\left(\mathrm{L}^{3} / \mathrm{T}\right.$, where $\mathrm{L}$ represents units of length and $\mathrm{T}$ represents units of time),

$K=$ hydraulic conductivity $(\mathrm{L} / \mathrm{T})$,

$I=$ hydraulic gradient (dimensionless), and

$A=$ cross-sectional area of porous medium $\left(\mathrm{L}^{2}\right)$.
In the area near Enoch, Thomas and Taylor (1946, p. 169-170) estimated that 5,000 acre-ft/yr enters Cedar Valley from Parowan Valley based on the estimated 3,000 acre-ft/yr of discharge from springs in the area northwest of Enoch. Sandberg (1966, p. 17) used Darcy's Law to estimate 1,000 acre-ft/yr of subsurface inflow from Parowan Valley through unconsolidated basin fill. In addition, Sandberg (1966, p. 17) reported diminished spring discharge near Enoch of 2,000 acre-ft/yr. It is possible that all of the spring discharge is derived from inflow from Parowan Valley, and the inflow is closer to 2,000 acre-ft/yr than 1,000 acre-ft/yr. On the basis of these estimates, subsurface inflow from Parowan Valley prior to large-scale ground-water development is estimated to range from 2,000 to 5,000 acre-ft/yr.

Bjorklund and others (1978, p. 45) reported that subsurface inflow from Parowan Valley into Cedar Valley was negligible. They suggested that the Red Hills, which separate the two basins, act as an effective barrier to flow. Evaporation from Little Salt Lake in Parowan Valley, an area of natural discharge, accounts for all excess water available for discharge. They suggested that a small amount of subsurface flow, however, may occur through Parowan Gap, the natural drainage for Little Salt Lake. The direction of ground-water flow that is shown on the potentiometric-surface map for March 1974 in Bjorklund and others (1978, pl. 5) indicates the possibility of some ground-water flow through the Red Hills. Since the study of Bjorklund and others (1978), sparse water-level data have been collected in this area as part of the USGS annual ground-water monitoring network. These data 
indicate that the ground-water flow direction in the area east of the Red Hills may be to the southwest toward Enoch.

Although spring discharge in the area north of Enoch has ceased, more water is needed than what can be provided by local recharge to meet present ground-water withdrawal. As indicated in table 3, an estimated 2,100 acre-ft/yr of recharge is derived from the Red Hills, Fiddlers, and Enoch areas. This is substantially less than the estimated 4,600 acre-ft of water that was withdrawn by wells during 2000 along the basin margin adjacent to these areas. Based on this difference between recharge and ground-water withdrawal in this area, a minimum of 2,500 acre-ft/yr subsurface inflow could be derived from the area east of Enoch and the Red Hills. Water levels in this area, however, generally declined about $15 \mathrm{ft}$ from 1989 to 2001, as indicated by water levels in wells (C-3411)36dcc-2 and (C-35-10)7abc-1 (Howells and others, 2002, table 2). The water level in well (C-34-11)36dcc-2 declined about $35 \mathrm{ft}$ from 1955 to 2001 . The declining water levels indicate that the discharge exceeds recharge and that flow from Parowan Valley and consolidated rock is less than ground-water withdrawal in this area.

Some subsurface inflow probably occurs through the unconsolidated material beneath Coal Creek where it enters the basin in Cedar City. The ground-water hydraulic gradient is assumed to be equal to the stream gradient (50 ft/mi), the saturated thickness of unconsolidated material is assumed to equal $20 \mathrm{ft}$, the canyon width at its mouth is $660 \mathrm{ft}$, and hydraulic conductivity of the unconsolidated material is estimated to be $10 \mathrm{ft} / \mathrm{d}$. Through the use of Darcy's Law (eq. 3), subsurface inflow beneath Coal Creek is estimated to be only 50 acre-ft/yr. Unless the saturated thickness and hydraulic conductivity are considerably larger, subsurface inflow beneath Coal Creek is negligible.

Ground-water conditions along the southern boundary have changed since the previous study because of increased withdrawals. Bjorklund and others (1978, p. 45 and pl. 5) reported that the ground-water divide was slightly north of the surface-water divide (study-area boundary) and, therefore, no subsurface inflow occurred. Water-level data collected during this study, although sparse, indicate that the ground-water divide is south of the study-area boundary. Because of the more recent conditions, some ground-water inflow may have been induced. Through the use of Darcy's Law (eq. 3), estimated subsurface inflow is about $500 \mathrm{acre}-\mathrm{ft} / \mathrm{yr}$. This estimate assumes a cross-sectional length of $2 \mathrm{mi}$ and a saturated thickness of $450 \mathrm{ft}$ as indicated by thickness contours of unit A reported by Hurlow (2002, fig. 10B).
The sparse water-level data indicate a hydraulic gradient of $10 \mathrm{ft}$ over a distance of $1.5 \mathrm{mi}$, which equals 0.0013 , with an average hydraulic conductivity of $10 \mathrm{ft} / \mathrm{d}$. The estimated subsurface inflow of 500 acre-ft/yr should be considered a maximum value because sources of recharge are few and because of uncertainties in estimated values used in the calculation.

\section{Discharge}

Present discharge from the ground-water system in Cedar Valley is primarily by ground-water withdrawal for irrigation and municipal uses. Other components of discharge include evapotranspiration, and to a lesser degree, subsurface outflow and spring discharge (table 2). Prior to large-scale ground-water development, natural discharge by evapotranspiration and from springs was much greater. Most of the withdrawal occurs south of Enoch; a small amount occurs between Enoch and Rush Lake.

\section{Wells}

The ground-water withdrawal data are derived from several sources. Early estimates of ground-water withdrawal for irrigation generally were made for only the central part of the basin. Estimates of irrigation ground-water withdrawal for each well were made by the Utah State Engineer for 1938-40 and reported by Thomas and Taylor (1946, p. 129-133). No estimates were made for 1941-44 because of incomplete data (Thomas and others, 1952, p. 27). Estimates for 1945-52 at each irrigation well are reported by Thomas and others (1952, table 1), and for 1953 are reported by Waite and others (1954, table 7). Sandberg (1962, table 3) reported irrigation ground-water withdrawals during 1954-60 and, beginning in 1956, estimates included irrigation wells throughout the valley. Since the early 1960s, most of the annual estimates of irrigation ground-water withdrawal have been made by Cedar Valley water commissioners and reported to the Utah Division of Water Rights. Except for a few years, these reported estimates have been used in the annual ground-water conditions reports produced by the USGS in cooperation with the Utah Division of Water Resources and Utah Division of Water Rights. During the data-collection phase of the study completed by Bjorkland and others (1978) and in recent years (1997-2001), estimates reported in the annual ground-water conditions reports for irrigation ground-water withdrawals have been made by the USGS. Data estimating ground water used for residential and industrial purposes have been 
obtained from the municipality or private water company and, since 1979, these data have been reported to the Utah Division of Water Rights.

Ground water withdrawn from wells historically has been used for irrigation and stock watering. Municipal water primarily was derived from springs discharging from consolidated rocks in the mountains and a lesser amount from wells. Since estimates of ground-water withdrawal were first made in the 1930s, increases in ground-water development were gradual until the early 1960s (fig. 7). Prior to the 1960s, most of the ground water withdrawn was used to irrigate cropland where no surface water was available or to augment applied surface water after the snowmelt runoff had subsided in Coal Creek. Average ground-water withdrawal for 1938-49 was 13,200 acre-ft/yr. In the early 1960s, ground-water withdrawals began to increase because of expansion of irrigated lands beyond the surface-water distribution system and decreased reliance on surface water for existing irrigated lands. Ground-water withdrawal for irrigation increased from about 21,000 acre-ft in 1963 to a maximum of almost 40,000 acre-ft in 1975. From 1983 through 1988, ground-water withdrawal for irrigation declined to values similar to those prior to the early 1960s. This decline was the result of unusually high streamflow in Coal Creek (fig. 3), which supplied an abundance of irrigation water and caused flooding of some irrigated lands. Ground-water withdrawal in 2000 was estimated to be 36,000 acre-ft, almost three times more than the amount representative of the period prior to large-scale ground-water development.

Ground-water withdrawal for public supply did not begin to substantially increase until the early 1970s with the largest increases occurring in the 1990s (fig. 7). The latter increases are primarily the result of a rapidly increasing population with its associated residential development. Much of the increased municipal water use is caused by increased summer lawn watering. To meet this increased demand, the municipalities of Cedar City and Enoch have had to rely on acquiring existing large production wells and, more recently, drilling new wells. Because of poor ground-water quality within the vicinity of Cedar City, beginning in the 1960s the city has developed a well field west of Quichapa Lake and additional wells to the north of Cedar City. Similarly, Enoch has acquired large production wells within its limits and recently (1999) has drilled an additional well in order to meet demands.

\section{Evapotranspiration}

Ground-water discharge by evapotranspiration may occur as transpiration by plants with roots that tap the shallow water table or by evaporation from playas or dry lakebeds where the water table is close to land surface. Thomas and Taylor (1946, p. 103-106) estimated 3,200 acre-ft of transpiration from plants and 1,000 acre-ft of evaporation from playa surfaces. Bjorklund and others (1978, p. 43-44) reported similar estimates with 1,600 acre-ft of plant transpiration and not more than 500 acre$\mathrm{ft}$ of evaporation. Both estimates for plant transpiration appear to be low considering the probable maximum areal extent for phreatophyte vegetation (Bjorklund and others, 1978, pl. 7) and the close proximity of the shallow water table during the study by Thomas and Taylor (1946). In some areas, Thomas and Taylor (1946, p. 104) reported that water levels were higher in the decades prior to the 1930s with water filling into newly dug post holes. Generally, evapotranspiration was reported to have occurred where the depth to water was less than $10 \mathrm{ft}$. Other studies in adjacent valleys suggest that evapotranspiration can occur where roots of phreatophyte vegetation penetrate to depths of 20-30 ft. White (1932, p. 92-93) reported that greasewood, the only important phreatophyte in the Beryl-Enterprise area, grew where the depth to water ranged from 7 to $30 \mathrm{ft}$. Mason (1998, p. G16) used an extinction depth for evapotranspiration of $30 \mathrm{ft}$ in ground-water model simulations in the Milford area because this depth to water corresponds to the areal extent of phreatopytes mapped by Mower and Cordova (1974, pl. 3).

A revised estimate was made for evapotrans-piration during 1938-40, the period studied by Thomas and Taylor (1946). Where the depth to water was less than 15 $\mathrm{ft}$ within the probable maximum areal extent of phreatophyte vegetation delineated by Bjorklund and others (1978, pl. 7), evapotranspiration is assumed to occur. The rate of evapotranspiration for phreatophyte vegetation within these areas is assumed to be $0.5 \mathrm{ft} / \mathrm{yr}$.

This assumed rate was extrapolated from a linear plot developed by Nichols (2000, fig. A7) for areas in the Great Basin where evapotranspiration rate is correlated to depth of ground water. Because streamflow in Coal Creek was below the long-term average for 2 years during 1938-40, ground-water levels in the area affected by surface-water recharge were lower. The assumed evapotranspiration rate may be lower than what would be representative of long-term average streamflow and recharge. The assumed rate of $0.5 \mathrm{ft} / \mathrm{yr}$ was multiplied by 41,600 acres in the two delineated areas to obtain 20,800 


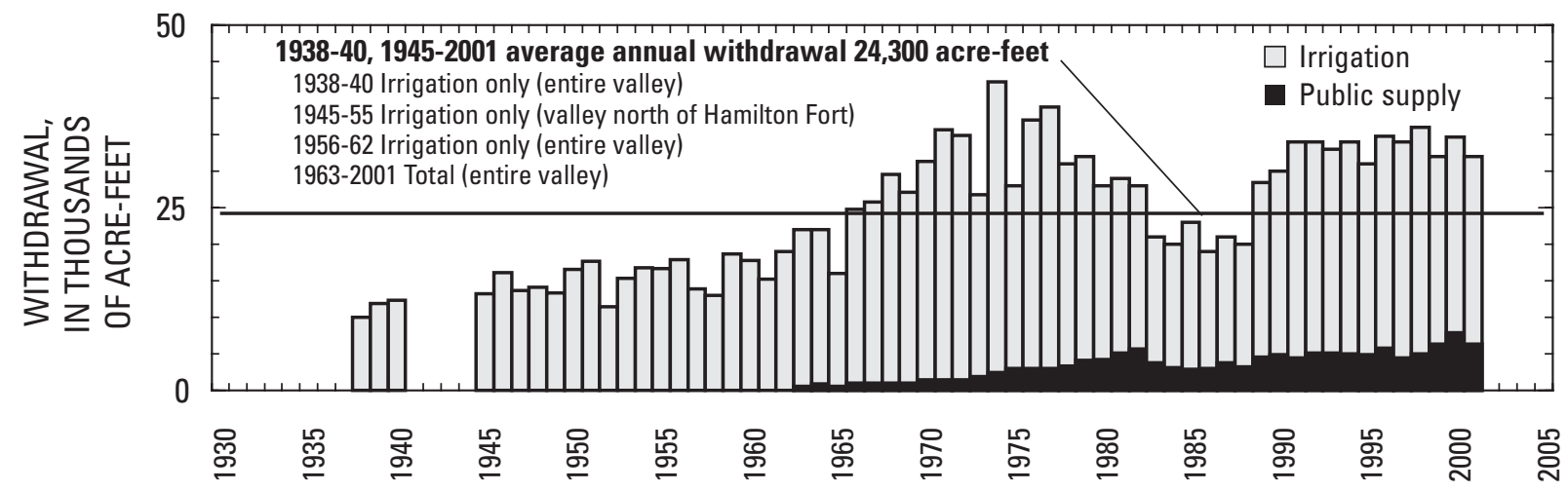

Figure 7. Ground-water withdrawal in Cedar Valley, Iron County, Utah. (Modified from Burden and others, 2002, fig. 25.)

acre-ft/yr. The estimate for evaporation from playa surfaces is assumed to be the same as the 1,000 acre-ft/yr reported by Thomas and Taylor (1946, p. 103-106) and, therefore, evapotranspiration was estimated to be about 22,000 acre-ft/yr during 1938-49.

This estimate of 1938-49 evapotranspiration also yields a more acceptable ground-water budget (table 2). Steady water levels during that period (Burden and others, 2002, fig. 25) indicate that recharge approximately equals discharge. With previous estimates of evapotranspiration, discharge and recharge in 1938-49 would be only $21,000 \mathrm{acre}-\mathrm{ft} / \mathrm{yr}$. If this were an accurate account of recharge, it is unlikely that withdrawals could have increased to 36,000 acre-ft/yr without causing more substantial water-level declines than have occurred.

Evapotranspiration for the year 2000 was estimated to be about 3,000 acre-ft, which is considerably less than the revised estimate for 1938-49. This estimate is based on the total area of riparian and phreatophyte vegetation in 2000 and the same evapotranspiration rate $(0.5 \mathrm{ft} / \mathrm{yr})$. Evaporation from playa surfaces is assumed to be less than that previously reported. The large decline in evapotranspiration is a result of decreased area of riparian and phreatophyte vegetation because of declining groundwater levels, which are a result of increased withdrawals.

\section{Springs and Subsurface Outflow}

Ground-water discharge by springs from unconsolidated basin fill within Cedar Valley has declined dramatically with increased ground-water withdrawals. Thomas and Taylor (1946, p. 103), reported discharge from springs to be about 4,260 acre-ft/yr, with 3,900 acre-ft/yr in the area near Enoch and about 360 acre-ft/yr at Iron
Springs in Iron Springs Gap where ground-water flow might be constricted by Cretaceous-age strata. Bjorklund and others (1978, p. 41-42) reported that spring discharge near Enoch was non-existent as a result of declining ground-water levels and that total discharge by springs and seeps from the unconsolidated basin fill was estimated to be less than 500 acre-ft/yr. Virtually all of this estimated discharge occurred at Iron Springs in Iron Springs Gap as it exits Cedar Valley and at two springs near Kanarraville, outside the study area. For the year 2000 , ground-water discharge by springs from unconsolidated basin fill was negligible.

Subsurface outflow from Cedar Valley is considered to be small. In previous studies, subsurface outflow was confined to the unconsolidated basin fill in the narrow outlets of Iron Springs Gap and Mud Springs Canyon. Estimates of subsurface outflow were made by multiplying the hydraulic gradient, cross-sectional area, and assumed permeability of the unconsolidated basin fill. Thomas and Taylor (1946, p. 103-104) estimated that about 75 acre-ft/yr exited Iron Springs Gap in addition to discharge at Iron Springs and 20 acre-ft/yr that exited at Mud Springs Canyon. Bjorklund and others (1978, p. 45) did not revise these estimates.

Estimates of subsurface outflow through Iron Springs Gap and in the vicinity of Mud Springs Canyon have been modified as a result of new ground-water-level data collected during this study. The configuration of the potentiometric surface for March 2000 (fig. 5) indicates that water levels in the vicinity of Iron Springs Gap are about $25 \mathrm{ft}$ lower than those reported by Thomas and Taylor (1946, pl. 13). The lack of discharge to Iron Springs is probably the result of these lowered groundwater levels. The combined natural discharge through 
Iron Springs Gap of about 435 acre-ft/yr reported by Thomas and Taylor (1946, p. 103-104) is now probably less than 100 acre-ft/yr. Subsurface data and hydraulic properties are not sufficient to further revise this estimate. Subsurface outflow in the vicinity of Mud Springs Canyon, however, is probably much larger than previously estimated. Potentiometric contours, based on sparse data from new domestic wells, indicate that subsurface ground-water outflow may extend as much as $8 \mathrm{mi}$ south of Mud Springs Canyon. If potentiometric contours were extended from the area with known data, the hydraulic gradient would be steep, which is indicative of material with low transmissivity. The thickness of unconsolidated basin fill in this area may range from less than 250 to 500 $\mathrm{ft}$ (Hurlow, 2002, fig. 10). Because water levels are more than $200 \mathrm{ft}$ below land surface, the saturated thickness probably is small. For these reasons, subsurface outflow in this area is considered to be about 1,000 acre-ft. More hydrogeologic data in this area are needed to refine this estimate.

\section{Trends in Water-Level Fluctuations}

Water-level fluctuations in wells completed in the unconsolidated basin fill in Cedar Valley, whether on a seasonal or a multi-year timescale, are the result of imbalances in recharge and discharge. Water-level rises occur when and where recharge is greater than discharge. Conversely, water-level declines occur if discharge is greater than recharge. The magnitude of water-level fluctuation depends upon aquifer properties and the location of the completed zone of a well, both horizontally and vertically, with respect to where most of the water is withdrawn and to source(s) of recharge. Wells located away from areas of large ground-water withdrawal or primary sources of recharge show minimal water-level fluctuations. Wells completed in areas with large withdrawals and at similar depths as withdrawal wells show large water-level fluctuations.

During this study water levels were measured twice each year for 2 years in about 150 wells (Howells and others, 2002, table 2). Water levels were measured in November after ground-water withdrawals for irrigation had ceased and in March prior to the new irrigation season. Water levels were measured in some wells more frequently and for a longer period. A continuous water-level recorder was in operation from April 1978 to July 1988 and from November 1998 to March 2001 for well (C-3611)8aab-1, in which water levels were first measured in 1935 (fig. 8).
Seasonal water-level fluctuations in wells are the result of changes in recharge and discharge, primarily ground-water withdrawal for irrigation during May through September followed by recovery and recharge during October through April. This trend can be seen in figure 8 where water levels are still rising when groundwater withdrawals resume in May. The extent of recovery from the previous irrigation season, therefore, cannot be measured because much of the response to recharge from seepage of water from Coal Creek is still occurring. Seasonal water-level fluctuations in wells at some distance from areas of large ground-water withdrawals and recharge are minimal, generally less than $1 \mathrm{ft}$. Most of these wells are located in the northern part of the basin and in some cases, along the basin margin.

Long-term trends for water levels in wells, depending on location, are the result of cumulative effects of precipitation and ground-water withdrawals. The approximate areas where each of these cumulative effects predominate are shown in figure 9. Hydrographs for wells that show water-level fluctuations typical for each of these areas are shown in figure 10.

For most of the historic data, water levels in wells that are located in the area west and north of Cedar City have tended to fluctuate with annual changes in precipitation, especially snowpack in the Coal Creek drainage basin. When flow in Coal Creek is much greater than the long-term average of 24,200 acre-ft (Burden and others, 2002, fig. 25), water levels rise because more water is available for recharge by seepage from ditches and stream channels and from irrigation (wells 1, 2, and 3 in fig. 10). Also, during years of greater-than-average streamflow, less ground water is withdrawn for irrigation. Conversely, water levels in wells decline when snowpack and streamflow are less than average. Because of the decreased streamflow, less recharge from streams and irrigation occurs and more ground water is withdrawn to meet agricultural demand. Water levels in wells in this area steadily declined during the 1950s and early 1960 s as a result of less-than-normal precipitation and streamflow (figs. 8 and 10). During the mid-1980s, greater-thannormal precipitation and record flow in Coal Creek resulted in rises such that water levels in many wells recovered to levels similar to or higher than those prior to large-scale ground-water development. Since the greaterthan-normal precipitation during 1978-88, water levels have declined. Water levels in March 2002 were typically about the same as in the early 1960s and 1978. Water 


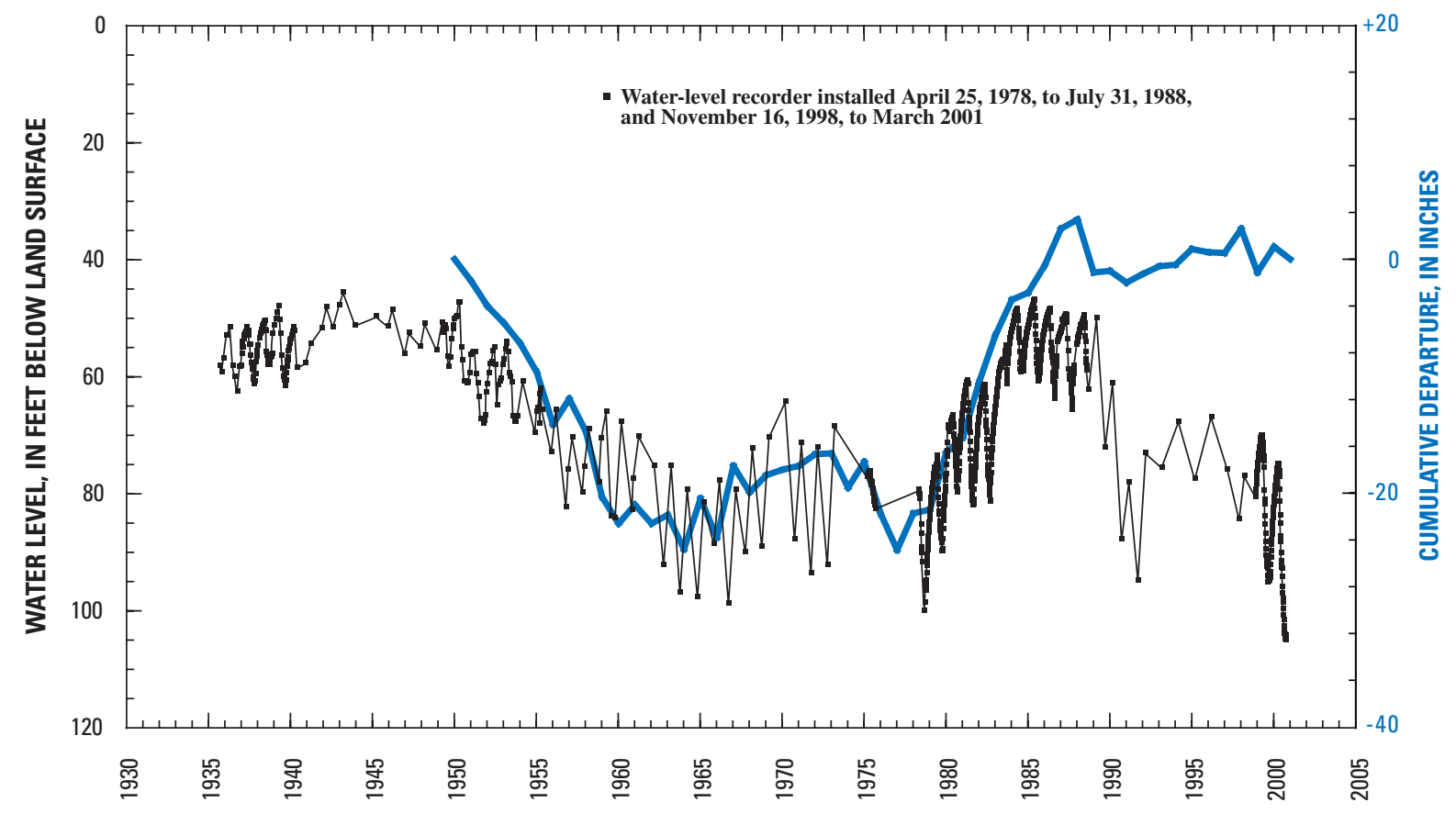

Figure 8. Relation of water levels in well (C-36-11)8aab-1 to cumulative departure from the average annual precipitation, Cedar Valley, Iron County, Utah.

levels in well 3 declined during the 1990s, despite nearnormal flow in Coal Creek. It is likely that discharge is exceeding recharge in this area during normal climatic conditions.

In the area southwest of Cedar City, water levels fluctuate in response to precipitation and streamflow but are more affected by increased withdrawal than in the area north of Cedar City. Less recharge from irrigation with water from Coal Creek occurs in this area, and the local recharge area receives less precipitation than the Coal Creek drainage basin. Water levels declined in response to the less-than-normal precipitation during the 1950s and early 1960s (wells 4, 5, and 6, fig. 10) and continued to decline in some wells until 1979 (wells 4 and 5). Water levels rose during the 1980s but did not recover to historic highs. This indicates that more water had been withdrawn from the system from the early 1950s to 1979 than was recharged during 11 years of greater-than-normal precipitation and streamflow. Water levels declined steadily and dramatically from 1989 to 2002, with typical declines of 25 to $35 \mathrm{ft}$ (wells 4, 5, 6, and 7). Discharge is exceeding recharge in this area and water levels will likely decline until the widening cone of depression captures recharge from other areas.

In the area north of Enoch to Rush Lake, water levels respond little to changes in precipitation and streamflow, and decline during periods of greater-than-normal withdrawals. During 1962-82, water levels declined 1 to $15 \mathrm{ft}$ (wells 8, 9, 10, and 11, fig. 10), mostly in response to increased withdrawal during the late 1960s and 1970s. Most of the withdrawal occurs south of this area but possibly captures water that previously flowed north to this area. Water-level rises during the 1980s were slight, indicating a lack of increased local recharge despite 11 years of greater-than-normal precipitation. Water levels appear to have stabilized in the northern part of the area (wells 8, 9, and 10) from the mid-1980s to 2002. It is possible that the decreased evapotranspiration in this area is balancing the 1990s withdrawal rates. Near Enoch, however, water levels declined about $20 \mathrm{ft}$ from 1988 to 2002, indicating that withdrawal exceeded recharge in that area. In much of the area north of Enoch, water levels were at or near historic low levels during March 2002. 


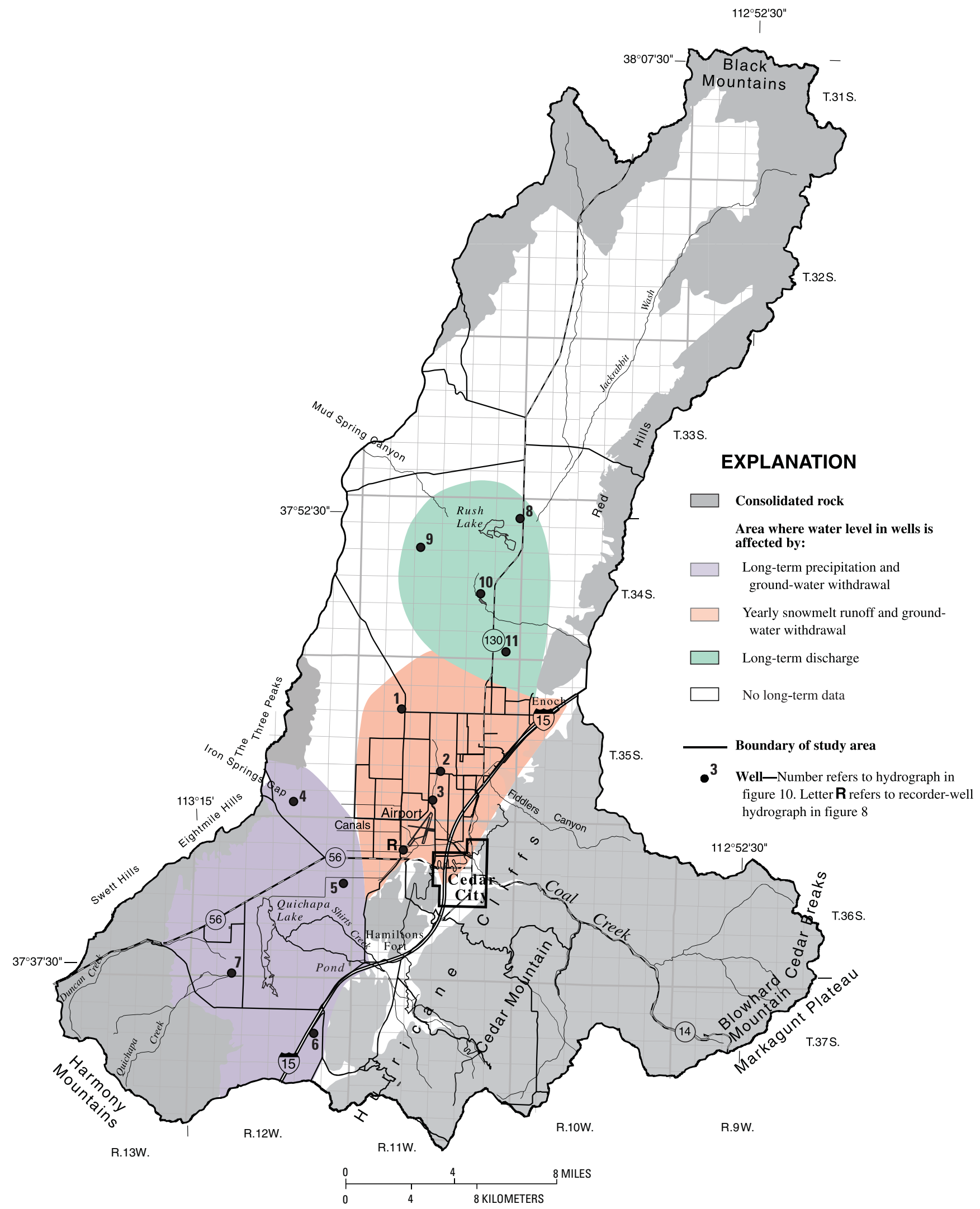

Figure 9. Approximate area where water levels in wells are affected by (1) long-term precipitation and ground-water withdrawal, (2) yearly snowmelt runoff and ground-water withdrawal, and (3) long-term discharge, Cedar Valley, Iron County, Utah. 

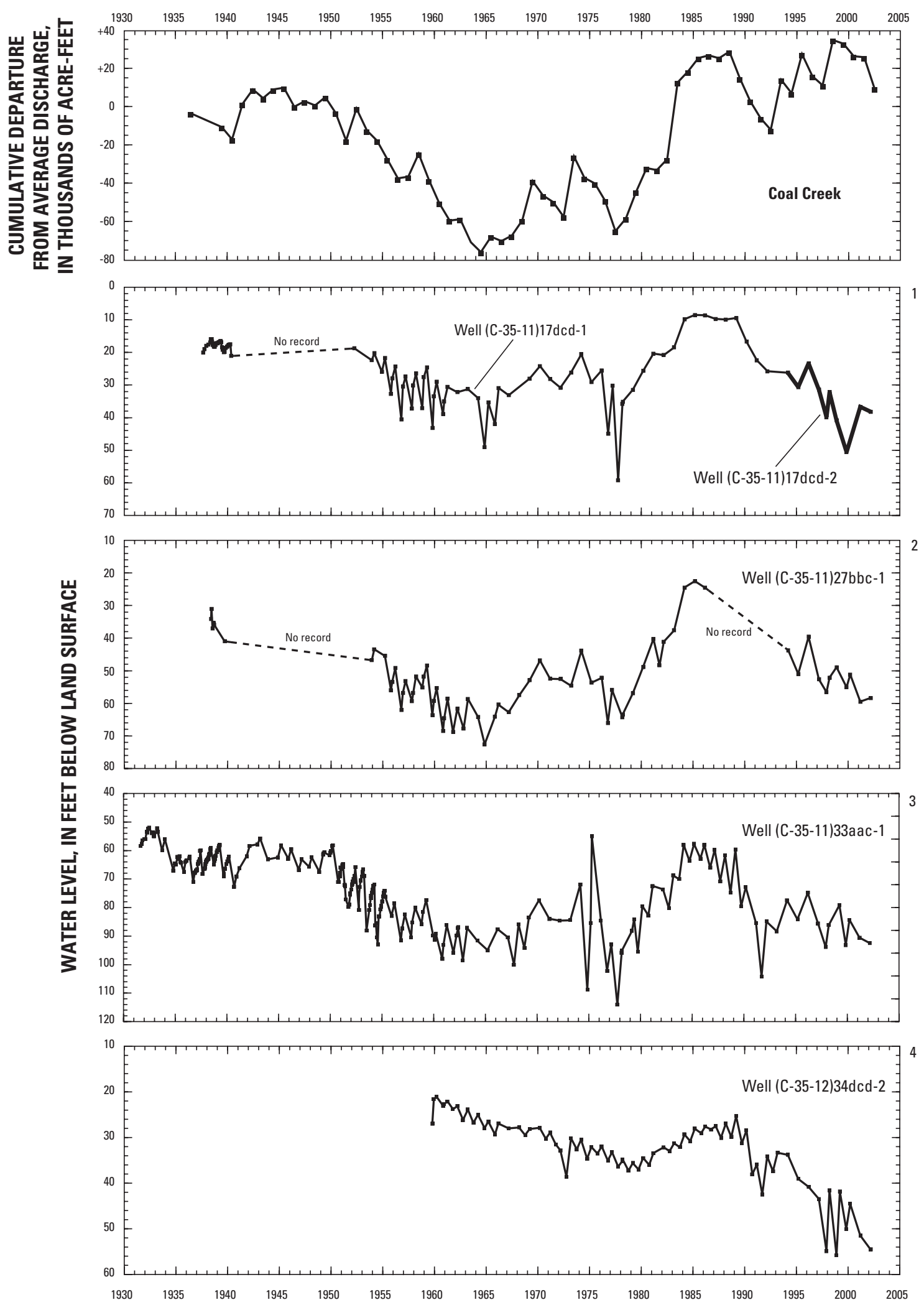

Figure 10. Relation of water levels in selected wells to cumulative departure from the average annual flow in Coal Creek, Cedar Valley, Iron County, Utah. 


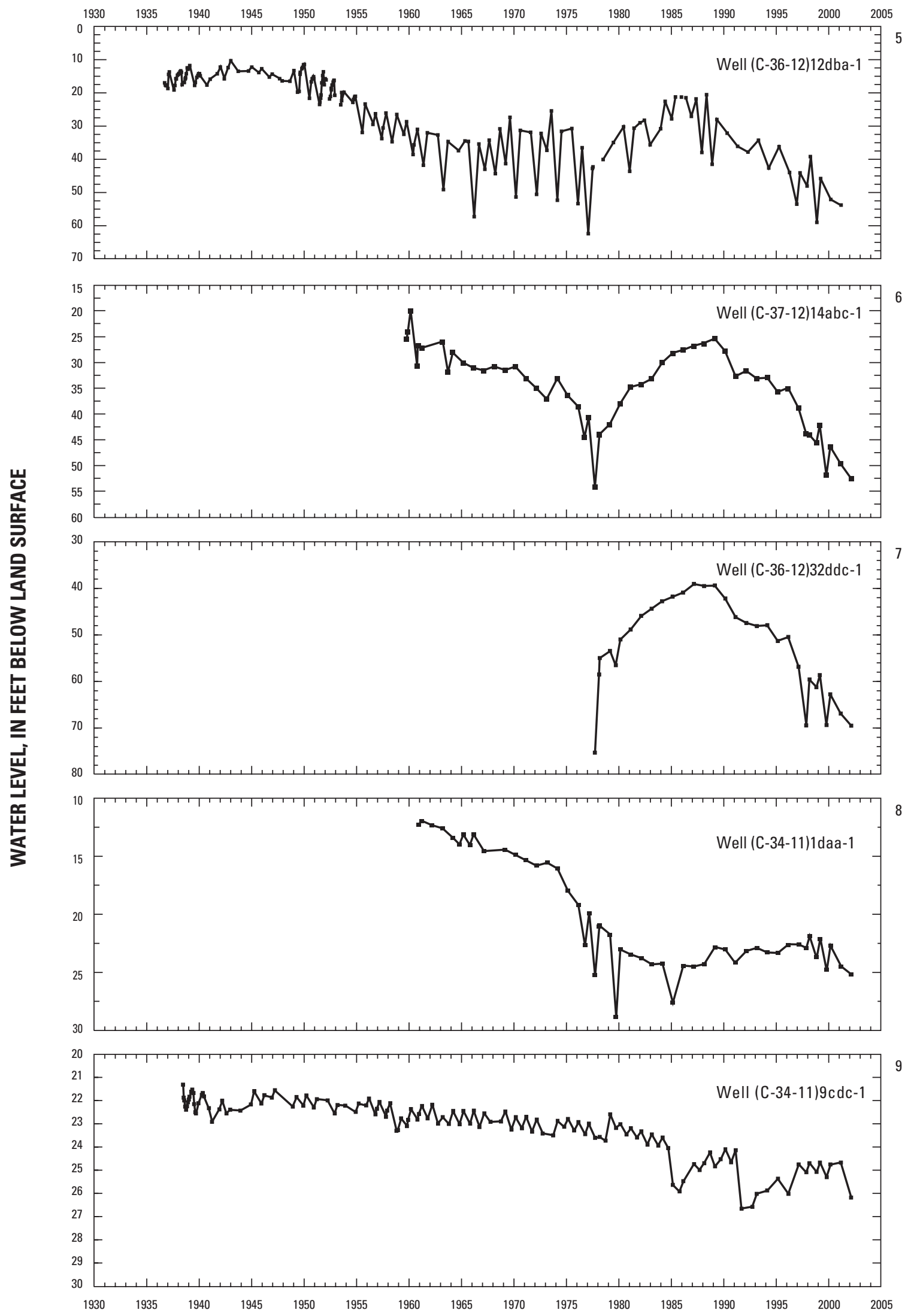

Figure 10. Relation of water levels in selected wells to cumulative departure from the average annual flow in Coal Creek, Cedar Valley, Iron County, Utah-Continued 


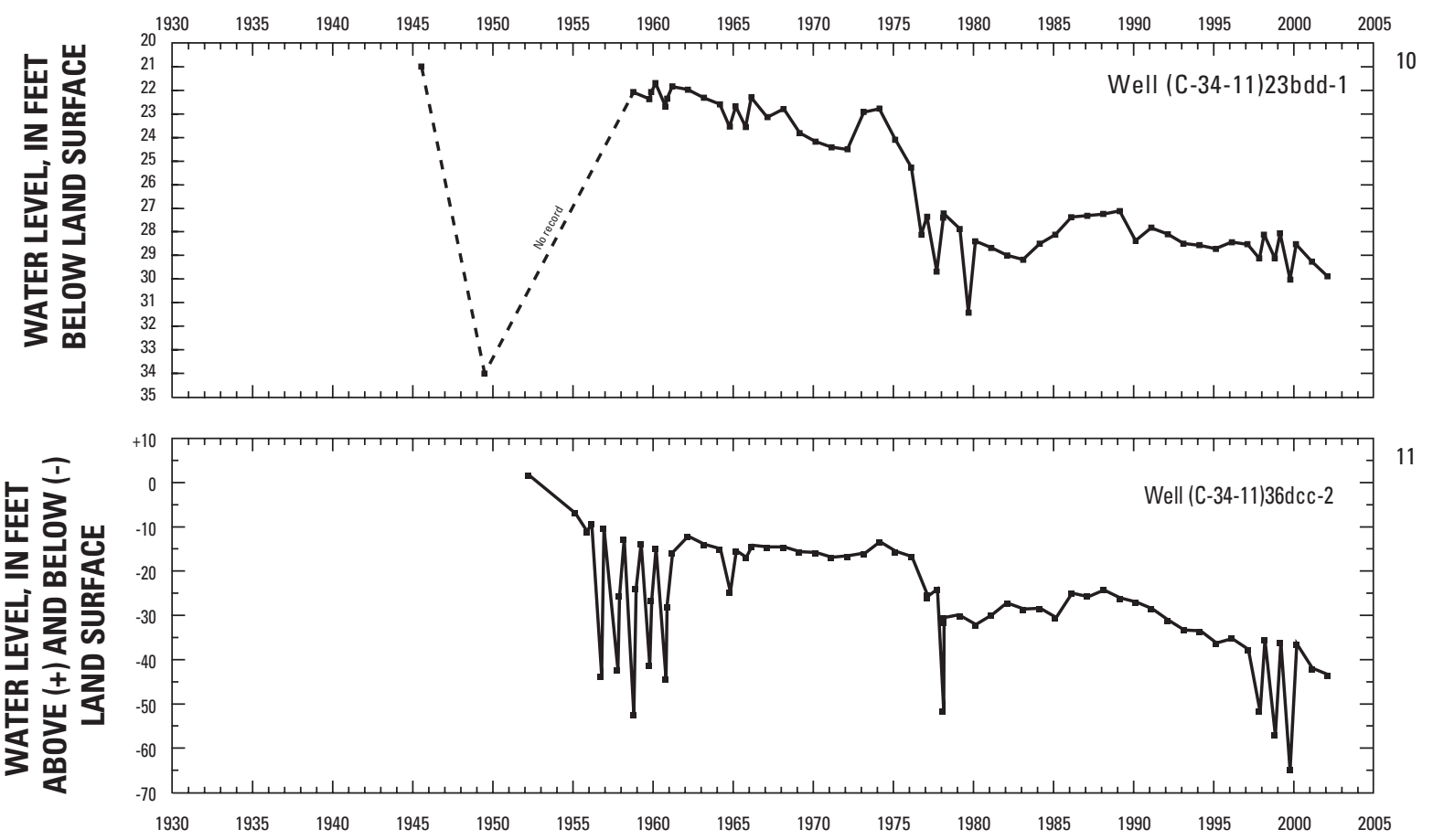

Figure 10. Relation of water levels in selected wells to cumulative departure from the average annual flow in Coal Creek, Cedar Valley, Iron County, Utah-Continued.

\section{Residual and Uncertainty}

Although recharge appears to equal or exceed discharge in the basin-wide water budget (table 2), continued declining water levels for the area where large amounts of ground water are withdrawn (fig. 10) indicate that recharge is not sufficient to meet demand. If recharge in the northern part of the basin is subtracted from total recharge in the 2000 water budget, then recharge in the southern part of the basin ranges from 36,000 to 38,000 acre-ft. Because water levels continue to decline, actual recharge in the southern part of the basin is probably less than the 36,000 acre-ft/yr withdrawn from wells.

Uncertainties in estimates of water-budget components result in uncertainties in the overall balance of both water budgets. Estimates of evapotranspiration for both water budgets have large uncertainties. The estimate for the predevelopment evapotranspiration was based only on the interpreted ground-water levels reported in Thomas and Taylor (1946) and the maximum extent of phreatophyte vegetation reported in Bjorklund and others (1978, pl. 7). No description for type of phreatopyhte vegetation and density is provided in either report. If the amount of predevelopment evapotranspiration was closer to the 3,200 acre-ft estimated by Thomas and Taylor (1946, p. 103-106), recharge would have to be much smaller to balance discharge for the predevelopment ground-water budget. Consequently, recharge would be insufficient to supply ground-water withdrawal in 2000. It is possible that recharge is less than estimated. New methods that account for monthly precipitation, vegetation cover, and soil moisture often estimate less recharge than Maxey-Eakin methods in areas with thick soil profiles (Hevesi and others, 2002, p. 24).

If additional data were to indicate that ground water in the shallow zones is isolated from the deeper production zones throughout much of the southern part of the basin as discussed previously in the "Movement" section of this report, then evapotranspiration would be more than estimated in both water budgets. More importantly, recharge in the 2000 ground-water budget would be less than discharge, which would result in declining groundwater levels. 


\section{Water Quality and its Implications for Ground-Water Flow}

Ground water is suitable for domestic use throughout most of the basin, but unsuitable along the eastern margin between Cedar City and Enoch, where elevated dissolved-solids and nitrate concentrations are present in water from several wells. Water managers need to know whether the quality of ground water has changed over time and whether possible future ground-water development would result in enlarging the area of water that is unsuitable for domestic use. To obtain a better understanding of water quality in Cedar Valley, water samples were collected from wells and surface-water sites for chemical analysis. Analyses included major and some minor chemical constituents, isotopes, and age-dating techniques. Chemical concentrations from these analyses were compared to historic data to assess long-term changes. Isotopes were used to examine probable water and chemical sources. Ground-water ages were determined to help understand ground-water flow paths and hydrologic processes.

Water-quality data from 1939 are reported in Thomas and Taylor (1946, p. 107-108). These data partially describe the ground-water quality in the unconsolidated basin fill of Cedar Valley because only bicarbonate $\left(\mathrm{HCO}_{3}\right)$, sulfate $\left(\mathrm{SO}_{4}\right)$, chloride $(\mathrm{Cl})$, nitrate $\left(\mathrm{NO}_{3}\right)$, and total hardness are listed. Although not reported, concentrations of other chemical constituents, such as calcium $(\mathrm{Ca})$, magnesium $(\mathrm{Mg})$, potassium $(\mathrm{K})$ and sodium $(\mathrm{Na})$, must have been determined for some samples because water types are mentioned (Thomas and Taylor, 1946, p. 109). Analyses from a small number of samples collected from wells during 1959-62 are reported by Sandberg (1963, table 4, and 1966, table 3). Chemical analyses of water collected from 43 wells and 4 springs, mostly during 1972-74, were reported by Bjorklund and others (1977, table 5). During this study, water was collected from 44 wells and 3 surface-water sites and the concentrations of major and minor ions are reported by Howells and others (2002, table 4). Location of the sampling sites is shown in figure 11. Map identifier, local identifier, and type of chemical analyses performed for each sampling site are presented in table 4.

\section{Major-Ion Chemistry}

Surface water in Cedar Valley is suitable for the intended use of irrigation and livestock watering. Additional chemical analyses would be required to evaluate whether surface water in the study area is suitable for public supply. Specific-conductance values in Coal Creek, which are proportional to dissolved-solids concentrations, are generally less than $1,000 \mu \mathrm{S} / \mathrm{cm}$. Specific conductance is a measure of the ability for water to conduct an electrical current. The proportionality constant that relates specific conductance to dissolved-solids concentration generally ranges from 0.55 to 0.75 . The variation depends upon the relative amount of doubly charged ions but is generally consistent within an area or aquifer (Hem, 1985, p. 67). Specific conductance, as measured in Coal Creek at USGS streamflow-gaging station 10242000 during 1967-91, varies with streamflow. This variation, however, is small relative to the variation in streamflow (fig. 12). Higher specific-conductance values generally coincide with low streamflow.

Three outlying specific-conductance values of about 1,500 $\mu \mathrm{S} / \mathrm{cm}$ occurred during August and September 1967. Chemical analyses of these samples indicate that sulfate concentrations are about 10 times higher than sulfate concentrations in samples collected during this study. Calcium concentrations are about five times higher than those obtained during this study. Sodium and $\mathrm{Cl}$ concentrations were three to eight times higher than in recent samples. Although no alkalinity or $\mathrm{HCO}_{3}$ values were reported for the samples collected in 1967, these data indicate that dissolution of evaporite minerals were contributing to the higher dissolved-solids concentration during a short period of time. This increase may have resulted from runoff in a part of the watershed where exposed evaporite deposits are more prevalent, or a debris flow may have deposited evaporite material in the stream channel.

Surface-water samples were collected during this study for chemical analysis from three sites along the eastern margin of the basin. Samples were collected on three occasions at USGS streamflow-gaging station 10242000 on Coal Creek just upstream from Cedar City. Surface water was collected from two additional sites, one from perennial streamflow in Shirts Creek (miscellaneous site (C-36-11)31bda) and from the ephemeral drainage from Fiddlers Canyon (miscellaneous site (C35-11)36bac) after a rainstorm. Water types for surface water from the three sites are variations of four constituents, $\mathrm{Ca}, \mathrm{Mg}, \mathrm{HCO}_{3}$, and $\mathrm{SO}_{4}$. Water in Coal Creek is a $\mathrm{Ca}-\mathrm{Mg}-\mathrm{HCO}_{3}$ type (fig. 13); in Shirts Creek, the water type is $\mathrm{Ca}-\mathrm{HCO}_{3}-\mathrm{SO}_{4}$; and in the ephemeral flow in Fiddlers Canyon, the water type is Ca-Mg- $\mathrm{SO}_{4}-\mathrm{HCO}_{3}$. 


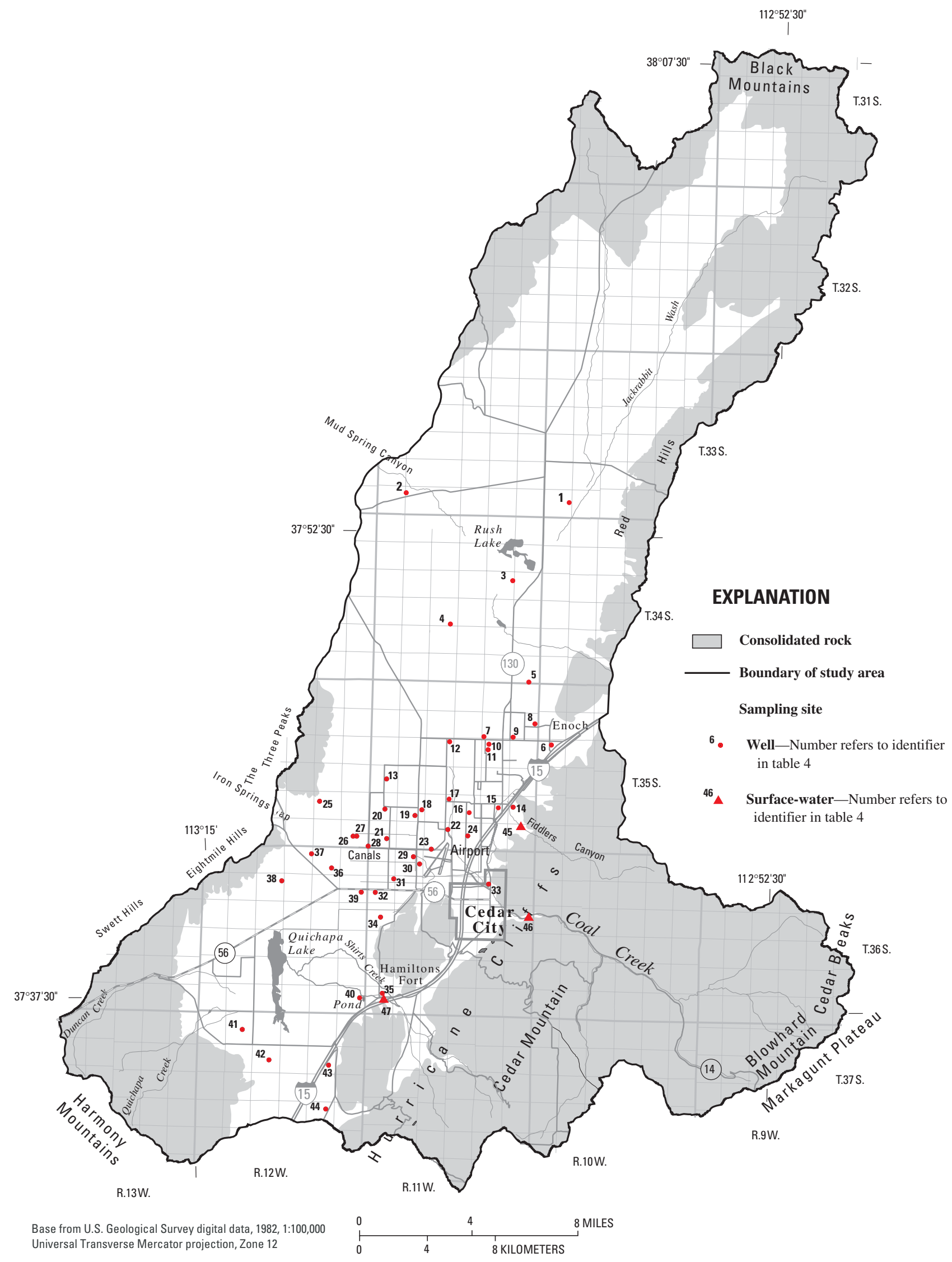

Figure 11. Location of sites sampled for chemical analysis, Cedar Valley, Iron County, Utah. 
Table 4. Map and local identifier and chemical analyses done for water from each sampling site, Cedar Valley, Iron County, Utah

[Analysis type: C, major and minor ion chemistry (Howells and others, 2002, table 4); I, deuterium and oxygen- 18 isotopes in table 5; N, nitrogen-15 isotope in table 8 ; CFC, chlorofluorocarbon recharge dates in table $6 ; \mathrm{H}$, tritium /helium-3 age dates and dissolved gases in table 7; USGS, U.S. Geological Survey]

\begin{tabular}{|c|c|c|}
\hline $\begin{array}{c}\text { Map } \\
\text { identifier }\end{array}$ & $\begin{array}{c}\text { Local } \\
\text { identlfier }\end{array}$ & Analysis type \\
\hline 1 & (C-33-10)31ada-1 & $\mathrm{C}, \mathrm{I}, \mathrm{N}$ \\
\hline 2 & (C-33-11)31aad-1 & $\mathrm{C}$ \\
\hline 3 & (C-34-11)14aad-2 & $\mathrm{C}$ \\
\hline 4 & (C-34-11)21dcd-1 & $\mathrm{C}$ \\
\hline 5 & $(\mathrm{C}-34-11) 36 \mathrm{dcc}-3$ & $\mathrm{C}$ \\
\hline 6 & $(\mathrm{C}-35-10) 18 \mathrm{abc}-1$ & $\mathrm{C}, \mathrm{CFC}$ \\
\hline 7 & (C-35-11)11ccc-1 & $\mathrm{C}, \mathrm{I}, \mathrm{N}$ \\
\hline 8 & (C-35-11)12add-1 & $\mathrm{C}$ \\
\hline 9 & $(\mathrm{C}-35-11) 12 \mathrm{ccc}-2$ & $\mathrm{C}, \mathrm{I}, \mathrm{N}$ \\
\hline 10 & (C-35-11)14bca-1 & $\mathrm{C}, \mathrm{I}, \mathrm{N}$ \\
\hline 11 & (C-35-11)14bac-2 & $\mathrm{C}, \mathrm{H}, \mathrm{I}$ \\
\hline 12 & (C-35-11)16aab-1 & $\mathrm{C}, \mathrm{I}, \mathrm{N}$ \\
\hline 13 & (C-35-11)19dbb-1 & $\mathrm{C}$ \\
\hline 14 & (C-35-11)25bcc-1 & $\mathrm{C}, \mathrm{H}, \mathrm{I}, \mathrm{N}$ \\
\hline 15 & (C-35-11)26acd-1 & $\mathrm{C}, \mathrm{CFC}, \mathrm{I}, \mathrm{N}$ \\
\hline 16 & (C-35-11)27dbb-1 & $\mathrm{C}, \mathrm{I}, \mathrm{N}$ \\
\hline 17 & (C-35-11)28aac-2 & $\mathrm{C}, \mathrm{CFC}, \mathrm{I}, \mathrm{N}$ \\
\hline 18 & (C-35-11)29add-1 & $\mathrm{C}, \mathrm{I}, \mathrm{N}$ \\
\hline 19 & (C-35-11)29dbd-2 & $\mathrm{C}, \mathrm{I}$ \\
\hline 20 & (C-35-11)30caa-1 & $\mathrm{C}$ \\
\hline 21 & (C-35-11)31dbd-1 & $\mathrm{C}$ \\
\hline 22 & (C-35-11)33abd-1 & $\mathrm{C}, \mathrm{I}, \mathrm{N}$ \\
\hline 23 & (C-35-11)33ccd-1 & $\mathrm{C}, \mathrm{I}, \mathrm{N}$ \\
\hline 24 & (C-35-11)34dbb-1 & $\mathrm{C}, \mathrm{I}, \mathrm{N}$ \\
\hline 25 & (C-35-12)26bca-1 & $\mathrm{C}$ \\
\hline 26 & (C-35-12)36саa-1 & $\mathrm{C}$ \\
\hline 27 & (C-35-12)36саa-2 & $\mathrm{C}, \mathrm{H}, \mathrm{I}$ \\
\hline 28 & (C-35-12)36ddd-1 & $\mathrm{C}, \mathrm{I}$ \\
\hline 29 & (C-36-11) 5aca-1 & $\mathrm{C}, \mathrm{CFC}, \mathrm{I}, \mathrm{N}$ \\
\hline 30 & (C-36-11) 5dab-1 & C,I \\
\hline 31 & $(\mathrm{C}-36-11) 7 \mathrm{aaa}-2$ & $\mathrm{C}, \mathrm{I}, \mathrm{N}$ \\
\hline 32 & (C-36-11) 7cab-1 & $\mathrm{C}$ \\
\hline 33 & (C-36-11)11bac-1 & $\mathrm{C}, \mathrm{I}, \mathrm{N}$ \\
\hline 34 & (C-36-11)18bdd-1 & $\mathrm{C}$ \\
\hline 35 & (C-36-11)31abc-1 & $\mathrm{C}, \mathrm{I}, \mathrm{N}$ \\
\hline 36 & (C-36-12) $2 \mathrm{dbc}-1$ & $\mathrm{C}$ \\
\hline 37 & (C-36-12) 3aad-2 & $\mathrm{C}$ \\
\hline 38 & (C-36-12) 9aac-1 & $\mathrm{C}$ \\
\hline 39 & (C-36-12)12dba-1 & $\mathrm{C}$ \\
\hline 40 & (C-36-12)36adb-1 & $\mathrm{C}$ \\
\hline 41 & $(\mathrm{C}-37-12) 5 \mathrm{acc}-2$ & $\mathrm{C}$ \\
\hline 42 & (C-37-12)9acc-1 & $\mathrm{C}$ \\
\hline 43 & $(\mathrm{C}-37-12) 11$ dac-1 & $\mathrm{C}$ \\
\hline 44 & (C-37-12)23abd-1 & $\mathrm{C}$ \\
\hline 45 & $(\mathrm{C}-35-11) 36 \mathrm{bac}$ & $\mathrm{C}$ \\
\hline 46 & USGS streamflow-gaging station 10242000 & $\mathrm{C}, \mathrm{I}$ \\
\hline 47 & (C-36-11)31bda & $\mathrm{C}$ \\
\hline
\end{tabular}

Chemical quality and water type of ground water varies throughout Cedar Valley. The spatial distribution of dissolved solids (fig. 14), indicates that high dissolvedsolids concentrations in water collected from wells located on the alluvial fan near Cedar City make it unsuitable for domestic use. Low dissolved-solids concentrations occur in water collected from wells located in the western part of the basin and near Enoch. Because high dissolved-solids concentrations in ground water near Cedar City make it unsuitable for domestic use, water for public supply is obtained from wells west of Quichapa Lake and north of the city toward Enoch. The dissolvedsolids concentration decreases toward the distal end of the alluvial fan probably as a result of dilution through recharge from seepage of applied irrigation water or seepage directly from Coal Creek.

Water type generally coincides with the dissolvedsolids concentration in ground water. The water type for water collected from selected wells in Cedar Valley is shown in figure 15. A spatial distribution of water types is reported in Bjorklund and others (1978, pl. 8). The concentration of chemical constituents in water and, consequently, the water type, is determined by the mineral composition of the porous medium, whether it is consolidated rock or unconsolidated basin fill derived from erosion of consolidated rock.

Ground water with a high dissolved-solids concentration, which occurs along the eastern margin of the basin, can be a Ca-SO $\mathrm{S}_{4}, \mathrm{Ca}-\mathrm{Mg}-\mathrm{HCO}_{3}-\mathrm{SO}_{4}$, or Ca-Mg$\mathrm{SO}_{4}-\mathrm{HCO}_{3}$ water type. The predominant ions of $\mathrm{Ca}$ and $\mathrm{SO}_{4}$ are likely derived by the dissolution of the mineral gypsum $\left(\mathrm{CaSO}_{4} \cdot 2 \mathrm{H}_{2} \mathrm{O}\right)$, which is prevalent in some of the Mesozoic-age sedimentary rocks that compose the Markagunt Plateau to the east. In addition, $\mathrm{Ca}$, along with $\mathrm{Mg}$ and $\mathrm{HCO}_{3}$, are derived from Mesozoic-age carbonate rocks.

Predominant ions in ground water for the area west of Quichapa Lake are $\mathrm{Ca}$ and $\mathrm{HCO}_{3}$ (Bjorklund and others, 1978, p. 49, pl. 8). Samples collected during this study from a small number of wells west of Quichapa Lake have similar major-ion concentrations. The adjacent Harmony Mountains, which are the primary source of unconsolidated basin fill in this area, are comprised of fractured Tertiary-age volcanic rocks. Unlike the Mesozoic-age sedimentary rocks of the Markagunt Plateau, these volcanic rocks are less susceptible to weathering and dissolution processes. As a result, ground water in this area typically has a dissolved-solids concentration of less than $500 \mathrm{mg} / \mathrm{L}$. 


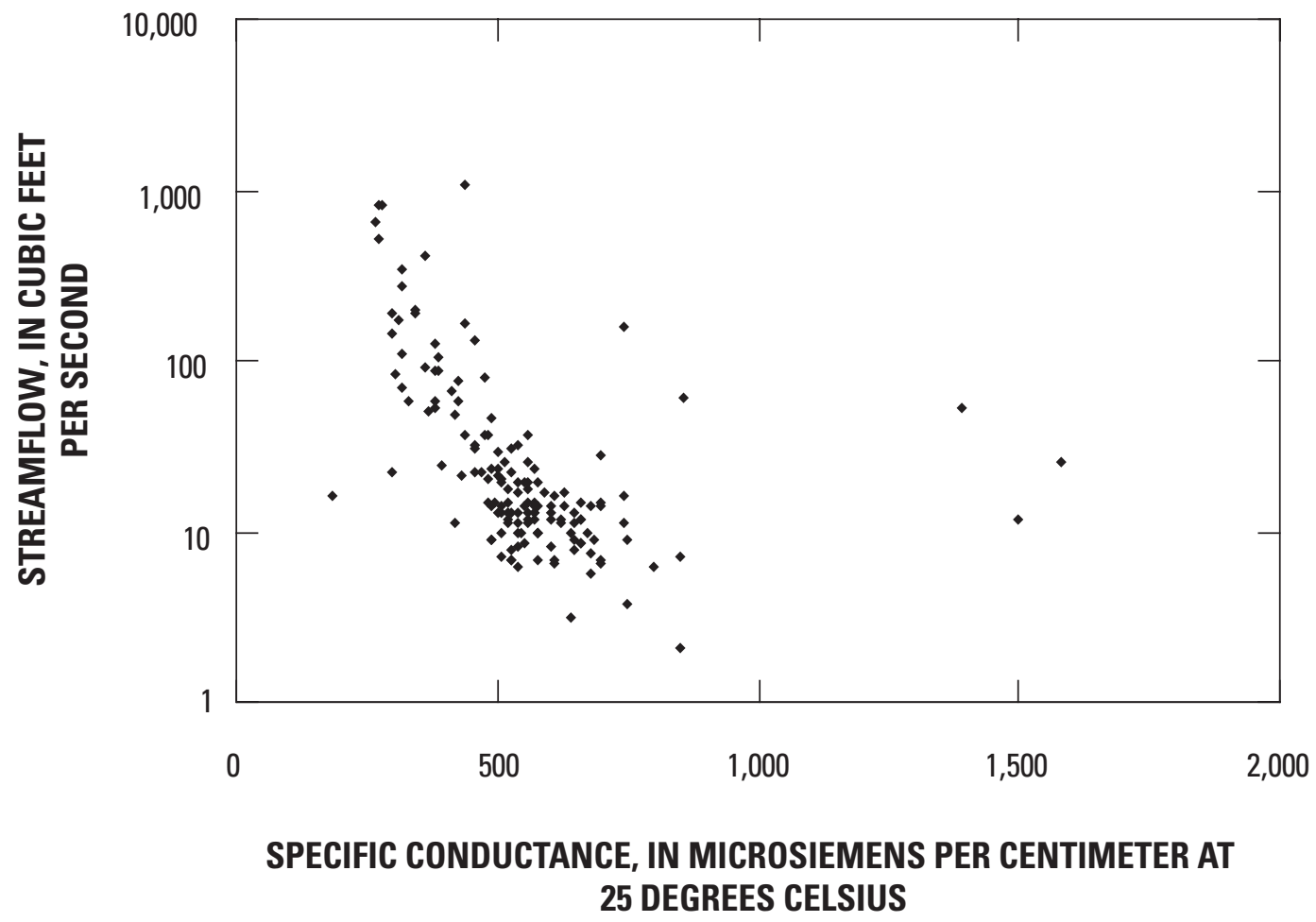

Figure 12. Relation of streamflow to specific conductance in Coal Creek at U.S. Geological Survey streamflow-gaging station 10242000, near Cedar City, Iron County, Utah.

Samples collected from the northernmost wells in the study area have prominent $\mathrm{Na}$ and $\mathrm{Cl}$ components not present at other locations. Bjorklund and others (1978, p. 49) suggested that water in shallow playa deposits beneath Quichapa and Rush Lakes has a high dissolvedsolids concentration consisting mostly of $\mathrm{Na}$ and $\mathrm{Cl}$. They also suggested that when surrounding ground-water levels are below the playa deposits, any seepage through these deposits would transport $\mathrm{Na}$ and $\mathrm{Cl}$ downward into the ground-water system. No shallow wells exist in the area of Quichapa and Rush Lakes from which samples can be collected. Another possible explanation for the high $\mathrm{Na}$ and $\mathrm{Cl}$ concentrations in water from wells in the northern part of the study area is discussed in the following "Isotope chemistry" section of this report.

Because of elevated dissolved-solids and nitrate concentrations in water from some wells along the eastern margin of the basin, water managers are concerned that this poorer-quality water may have or will in the future migrate westward along ground-water flow paths. Data collected during this study were compared to historic data to determine if any trends were evident. Other than minor differences in chemical concentrations, there is no evidence to indicate any deterioration in groundwater quality. These minor variations probably were the result of different pumping levels when samples were collected. Distinct strata within the principal aquifer may have different chemical concentrations. For instance, if the strata containing higher chemical concentrations are located toward the bottom of the well, then the poor-quality water will contribute a greater percentage to the water withdrawn from the well when the water level is low.

Ground-water flow transports dissolved solids from the area of higher dissolved-solids concentration near Cedar City westward through the alluvial fan toward the center of the basin. Recharge on the distal part of the alluvial fan by seepage from Coal Creek and applied irrigation water with lower dissolved-solids concentrations probably dilutes the ground water thereby constraining the area with poorer water quality. In addition, some irrigation wells located near the distal part of the alluvial fan may be withdrawing some water with a high dissolvedsolids concentration. 


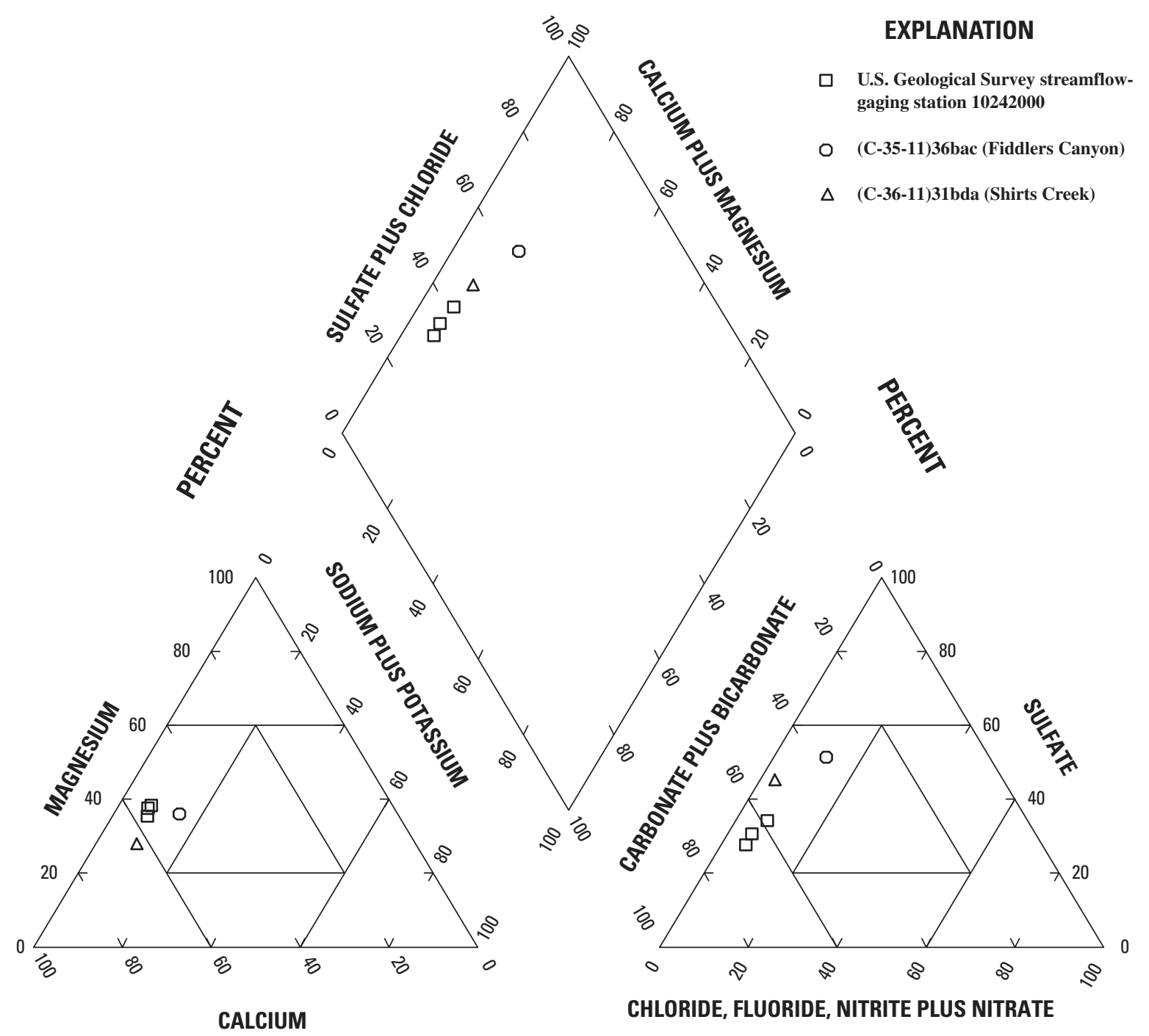

PERCENT

Figure 13. Chemical composition of surface-water samples collected at selected sites in Cedar Valley, Iron County, Utah.

\section{Isotope Chemistry}

Water samples from selected wells in Cedar Valley were analyzed for the stable isotopes of hydrogen $\left({ }^{2} \mathrm{H}\right)$, oxygen $\left({ }^{18} \mathrm{O}\right)$, and nitrogen $\left({ }^{15} \mathrm{~N}\right)$ to obtain a better understanding of the hydrologic processes in the groundwater system and evaluate possible source(s) of dissolved $\mathrm{NO}_{3}$. Results of ${ }^{15} \mathrm{~N}$ analyses are discussed in the "Nitrate source determination" section of this report.

Stable isotopes are analyzed by measuring the ratio of the heavier, less abundant isotope to the lighter, more abundant isotope and are reported as differences to a known standard. The reference to a heavier isotope indicates that the additional neutrons in an isotope increase the mass or atomic weight of the element. The isotope ratios are reported as delta $(\delta)$ values expressed as parts per thousand (permil or $\%$ oo ). The $\delta$ value for an isotope ratio $R$ is determined from the following equation:

$$
\delta R=\left(R_{\text {sample }} / R_{\text {standard }}-1\right) \times 1000
$$

where:

$\delta R=\delta$ value for a specific isotope in the sample;

$R_{\text {sample }}=$ the ratio of the rare isotope to the common isotope for a specific element in the sample; and 


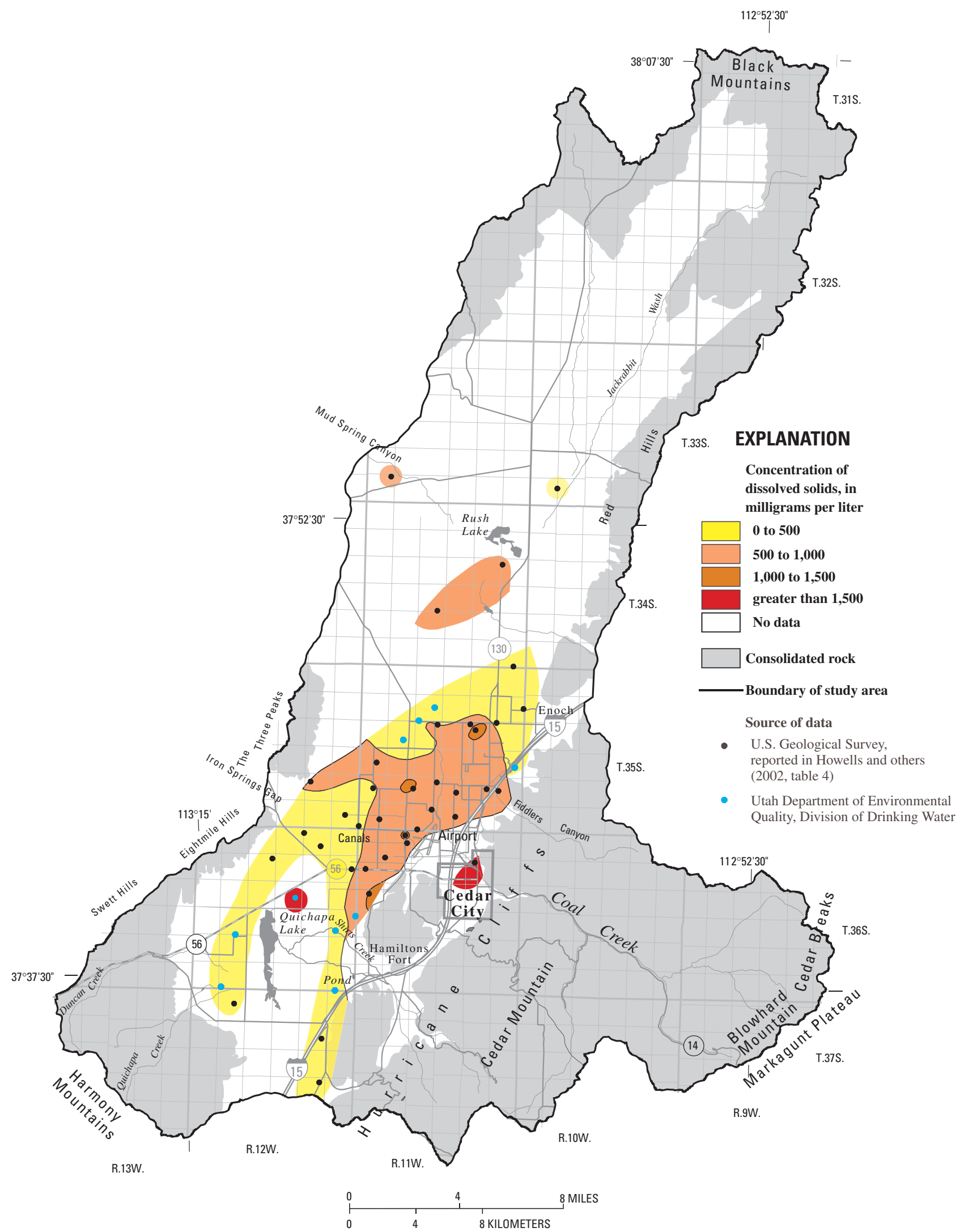

Figure 14. Approximate distribution of dissolved-solids concentration in water collected from selected wells, Cedar Valley, Iron County, Utah. 


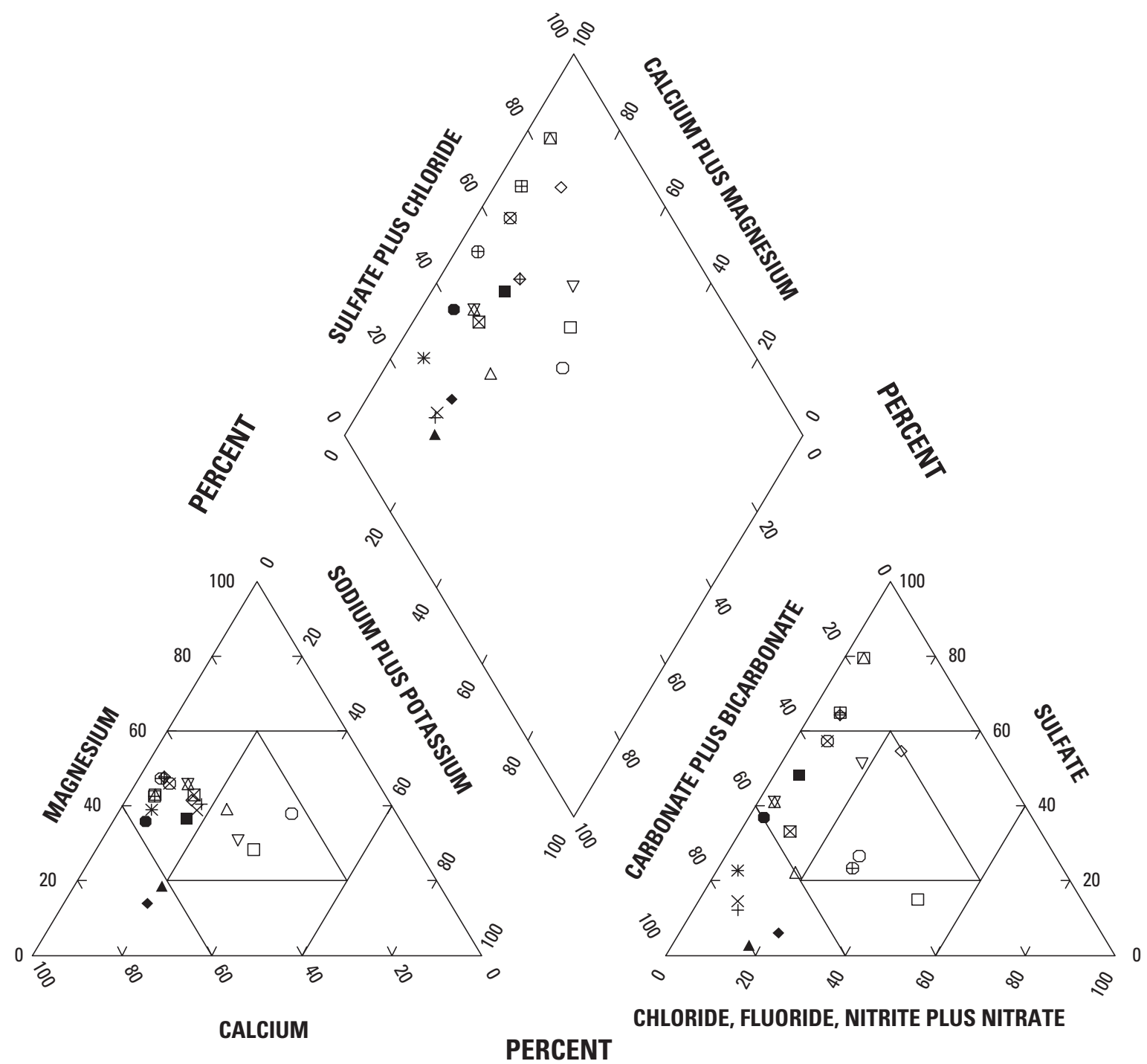

EXPLANATION

\begin{tabular}{|c|c|c|c|c|c|}
\hline Symbol & Local identifier & $\begin{array}{l}\text { Identifier } \\
\text { (fig. 11) }\end{array}$ & Symbol & Local identifier & $\begin{array}{c}\text { Identifier } \\
\text { (fig. 11) }\end{array}$ \\
\hline$\square$ & (C-33-10)31ada-1 & 1 & $\oplus$ & (C-35-11)34dbb-1 & 24 \\
\hline 0 & (C-34-11)14aad-2 & 3 & $\mathbb{8}$ & (C-35-12)36ddd-1 & 28 \\
\hline$\triangle$ & (C-34-11)36dcc-3 & 5 & $\boxplus$ & (C-36-11)5aca-1 & 29 \\
\hline+ & (C-35-10)18abc-1 & 6 & $\otimes$ & (C-36-11)7aaa-2 & 31 \\
\hline$x$ & (C-35-11)12add-1 & 8 & $\nabla$ & (C-36-11)11bac-1 & 33 \\
\hline$\diamond$ & (C-35-11)14bca-1 & 10 & $\mathbf{\square}$ & $(\mathrm{C}-36-12) 9 \mathrm{aac}-1$ & 38 \\
\hline$\nabla$ & (C-35-11)25bcc-1 & 14 & - & $(\mathrm{C}-36-12) 36 \mathrm{adb}-1$ & 40 \\
\hline$\otimes$ & (C-35-11)26acd-1 & 15 & $\Delta$ & (C-37-12)5acc-2 & 41 \\
\hline *⿻丷木 & (C-35-11)27dbb-1 & 16 & $\bullet$ & (C-37-12)9acc-1 & 42 \\
\hline$\oplus$ & (C-35-11)31dbd-1 & 21 & & & \\
\hline
\end{tabular}

Figure 15. Chemical composition of water collected from selected wells, Cedar Valley, Iron County, Utah 
$R_{\text {standard }}=$ the ratio of the rare isotope to the common isotope for the same element in the standard reference material.

In the isotope ratio $R$, the rare isotope is isotopically "heavier" than the common isotope. This is because the atomic weight of the rare isotope is more than that for the common isotope. A positive $\delta R$ value indicates that the sample is enriched in the "heavy" isotope with respect to the standard. Conversely, a negative $\delta R$ value indicates the sample is depleted in the heavy isotope with respect to the standard and is, therefore, isotopically "light" as compared to the standard.

Isotope fractionation is a change in value for $\delta R$ as a result of partitioning of an isotope through physical, chemical, and biological processes. Isotope partitioning between reactant and product phases or chemical species can occur through simple physical change in state, reversible equilibrium reactions, irreversible kinetic reactions, and molecular diffusion. The basis for isotope fractionation is the difference in bond strength between light and heavy isotopes for a given element. The heavy isotope has a stronger bond and will require more energy than the light isotope to dissociate in any of the processes listed above. Therefore, constituents that contain the light isotope will react more quickly. Because of the greater bond strength, the heavy isotope constituents generally are partitioned into the more condensed phase such as the solid phase in water-rock reactions or in the aqueous phase in vapor-liquid processes. For a more detailed discussion of this subject see Clark and Fritz (1997, p. 2133).

Isotope ratios of hydrogen $\left({ }^{2} \mathrm{H} /{ }^{1} \mathrm{H}\right)$ and oxygen $\left({ }^{18} \mathrm{O} /{ }^{16} \mathrm{O}\right)$ were determined for 22 samples collected from selected wells, 3 samples collected from Coal Creek, and 10 precipitation samples. The ${ }^{2} \mathrm{H} /{ }^{1} \mathrm{H}$ isotope ratios for these samples were determined by using a hydrogen equilibrium technique described by Coplen and others (1991) that measures ${ }^{2} \mathrm{H}$ activity. The ${ }^{18} \mathrm{O} /{ }^{16} \mathrm{O}$ isotope ratios were determined by using a carbon dioxide equilibrium technique described by Epstein and Mayeda (1953). In the calculation of $\delta$ values for ${ }^{2} \mathrm{H}$ and ${ }^{18} \mathrm{O}$ in equation 4, the ratio is referenced to Vienna Standard Mean Ocean Water (VSMOW). The $\delta^{2} \mathrm{H}$ and $\delta^{18} \mathrm{O}$ values are listed in table 5.

The relation between $\delta^{2} \mathrm{H}$ and $\delta^{18} \mathrm{O}$ values generally plots along a trend line known as the global meteoric water line (fig. 16). This trend can be described by the equation:

$$
\delta^{2} H=8 \times \delta^{18} O+d
$$

where $d$ is defined as the ${ }^{2} \mathrm{H}$ excess (Dansgaard, 1964, p. 456). The mean global value for $d$ in freshwater is 10 (Craig, 1961, p. 1702). On the basis of more recent global data, Rozanski and others (1993) have revised the equation for the global meteoric water line slightly such that the slope is 8.13 and the ${ }^{2} \mathrm{H}$ excess is 10.8 . The value for $d$ may differ depending on global location. Generally, the value for $d$ in North America is 6 (Coplen, 1993, p. 235). The values for $\delta^{2} \mathrm{H}$ and $\delta^{18} \mathrm{O}$ determined for samples collected during this study, however, generally plot along the global meteoric water line with values of 8 for the slope and 10 for $d$.

Only one ground-water sample, collected from well (C-33-10)31ada-1 in the northern part of the basin, deviates slightly from the global meteoric water line. This sample is enriched in ${ }^{18} \mathrm{O}$ relative to ${ }^{2} \mathrm{H}$, which could indicate that water is enriched by evaporation before it becomes recharge. This area receives less water from high-altitude snowmelt than the area around Cedar City and may be more dependent upon summer thundershowers for recharge. Summer precipitation is enriched in ${ }^{18} \mathrm{O}$ relative to ${ }^{2} \mathrm{H}$, probably by evaporation during precipitation. The valley in this area receives less precipitation than areas farther south and the water is probably more enriched by evapotranspiration as it moves through the root zone than is recharge water farther south. It is possible that the enrichment may indicate exchange of oxygen in water and rocks at high temperature (Coplen and others, 2000, p. 88) that could occur along basinbounding faults (Hurlow, 2002, fig. 10). Because the temperature of this water is not substantially higher than that of other samples (Howells and others, 2002, table 4), however, a deep geothermal source is unlikely.

Three surface-water samples were collected from Coal Creek at USGS streamflow-gaging station 10242000. Two samples were collected during the summer and one sample was collected during the spring. The $\delta^{2} \mathrm{H}$ and $\delta^{18} \mathrm{O}$ values for these samples have little seasonal variation and also generally coincide with values derived from ground-water samples (fig. 16).

Ten samples were collected at a weather observation station in Cedar City to determine $\delta^{2} \mathrm{H}$ and $\delta^{18} \mathrm{O}$ values in precipitation on a reconnaissance basis. The samples were evenly divided between winter and summer months. Not all occurrences of precipitation were sampled and, therefore, any correlation of isotopic values with amount of precipitation would not be relevant. Conclusions drawn from these data should be considered 
Table 5. $\delta^{2} \mathrm{H}$ and $\delta^{18} \mathrm{O}$ values in ground-water, surface-water, and precipitation samples from selected sites, Cedar Valley, Iron County, Utah

$\left[\delta^{2} \mathrm{H}\right.$, isotope ratio of hydrogen; $\delta^{18} \mathrm{O}$, isotope ratio of oxygen; permil, parts per thousand; USGS, U.S. Geological Survey]

\begin{tabular}{|c|c|c|c|}
\hline $\begin{array}{c}\text { Local } \\
\text { identifier }\end{array}$ & Date & $\begin{array}{c}\delta^{2} \mathrm{H} \\
\text { (permil) }\end{array}$ & $\begin{array}{c}\delta^{18} \mathbf{0} \\
\text { (permil) }\end{array}$ \\
\hline (C-33-10)31ada-1 & $06-12-2000$ & -110 & -14.09 \\
\hline (C-35-11)11ccc-1 & $07-25-2000$ & -107 & -14.61 \\
\hline$(\mathrm{C}-35-11) 12 \mathrm{ccc}-2$ & 08-25-1999 & -109 & -14.84 \\
\hline (C-35-11)14bac-2 & 03-13-2001 & -105 & -14.36 \\
\hline (C-35-11)14bca-1 & 08-25-1999 & -104 & -14.35 \\
\hline (C-35-11)16aab-1 & 09-01-1999 & -105 & -14.42 \\
\hline (C-35-11)25bcc-1 & $07-10-2001$ & -106 & -14.39 \\
\hline (C-35-11)26acd-1 & 08-24-1999 & -103 & -14.08 \\
\hline (C-35-11)27dbb-1 & 08-31-1999 & -100 & -13.90 \\
\hline (C-35-11)28aac-2 & 08-26-1999 & -102 & -14.00 \\
\hline (C-35-11)29add-1 & 08-27-1999 & -104 & -14.18 \\
\hline (C-35-11)29dbd-2 & $07-27-2000$ & -104 & -14.13 \\
\hline (C-35-11)33abd-1 & 08-25-1999 & -102 & -13.93 \\
\hline (C-35-11)33ccd-1 & 08-25-1999 & -101 & -14.02 \\
\hline (C-35-11)34dbb-1 & 09-01-1999 & -98 & -13.40 \\
\hline (C-35-12)36caa-2 & 03-14-2001 & -102 & -13.92 \\
\hline (C-35-12)36ddd-1 & 08-26-1999 & -106 & -14.72 \\
\hline (C-36-11) 5aca-1 & 08-26-1999 & -102 & -13.99 \\
\hline (C-36-11) 5dab-1 & 09-01-1999 & -101 & -14.12 \\
\hline (C-36-11) 7aaa-2 & 09-01-1999 & -103 & -14.14 \\
\hline (C-36-11)11bac-1 & 08-26-1999 & -103 & -14.13 \\
\hline (C-36-11)31abc-1 & $07-28-2000$ & -104 & -14.34 \\
\hline \multirow{2}{*}{$\begin{array}{l}\text { USGS streamflow- } \\
\text { gaging station }\end{array}$} & 07-27-1999 & -102 & -13.95 \\
\hline & $03-16-2000$ & -108 & -14.55 \\
\hline 10242000 & $06-13-2000$ & -105 & -14.08 \\
\hline \multirow{10}{*}{$\begin{array}{l}\text { Precipitation } \\
\text { (Cedar City) }\end{array}$} & 05-17--2001 & -105 & -12.7 \\
\hline & 05-29-2001 & -36 & -3.8 \\
\hline & $06-26-2001$ & -33 & -5.3 \\
\hline & 07-06-2001 & -36 & -1.4 \\
\hline & $07-10-2001$ & -27 & -4.7 \\
\hline & $11-25-2001$ & -118 & -14.7 \\
\hline & $12-04-2001$ & -90 & -12.7 \\
\hline & $12-15-2001$ & -135 & -18.2 \\
\hline & $12-30-2001$ & -152 & -19.2 \\
\hline & 01-30-2002 & -102 & -15.7 \\
\hline
\end{tabular}

preliminary and any definitive conclusions would require detailed sampling of all occurrences of precipitation along with an understanding of amount and spatial distribution.

Values for $\delta^{2} \mathrm{H}$ and $\delta^{18} \mathrm{O}$ in winter precipitation are more depleted (negative) than those in summer precipitation (Coplen, 1993, p. 234). The $\delta^{2} \mathrm{H}$ and $\delta^{18} \mathrm{O}$ values for winter samples cluster near those for ground water and surface water or are located somewhat lower on the meteoric water line. These data indicate that streamflow in Coal Creek and ground water in Cedar Valley are mostly derived from winter precipitation. Except during summer thunderstorms, most of the streamflow in Coal Creek is derived from either snowmelt runoff or base flow. Sources of base flow primarily include spring and subsurface discharge from consolidated rocks and a minor amount from bank storage. Water that discharges from consolidated rocks into Coal Creek is derived from recharge as the snowpack melts. Water in Coal Creek that is not consumed by evapotranspiration in Cedar Valley eventually becomes recharge to the ground-water system.

The $\delta^{2} \mathrm{H}$ and $\delta^{18} \mathrm{O}$ values for summer samples, however, clustered along the upper part of the meteoric water line. Summer precipitation generally comes into the area from the south and southwest with associated warm temperatures, typical of monsoonal weather patterns. One exception was a sample collected on May 17, 2001 , in which the $\delta^{2} \mathrm{H}$ and $\delta^{18} \mathrm{O}$ values were more representative of winter precipitation. This storm could have come from the northwest with colder associated temperatures than those that are representative of summer precipitation. The two summer samples that deviate from the meteoric water line are probably the result of evaporation resulting from a delay in sample processing, or of evaporation occurring during the rainfall.

\section{Ground-Water Age Dating and Recharge Temperature}

Ground-water age dating was used in an attempt to better understand recharge processes and to help delineate possible sources of $\mathrm{NO}_{3}$ in ground water. Samples for age dating were collected from a small number of wells that were sampled during this study for chemical analysis. Because of the requirements for the age-dating techniques used in this study, only a few wells were suitable to allow sampling without exposure to the atmosphere. Of the wells sampled, many had long perforated intervals and conclusions based on these data and presented below should be considered first approximations. More detailed sampling is needed before ground-water ages can be determined throughout the basin. 


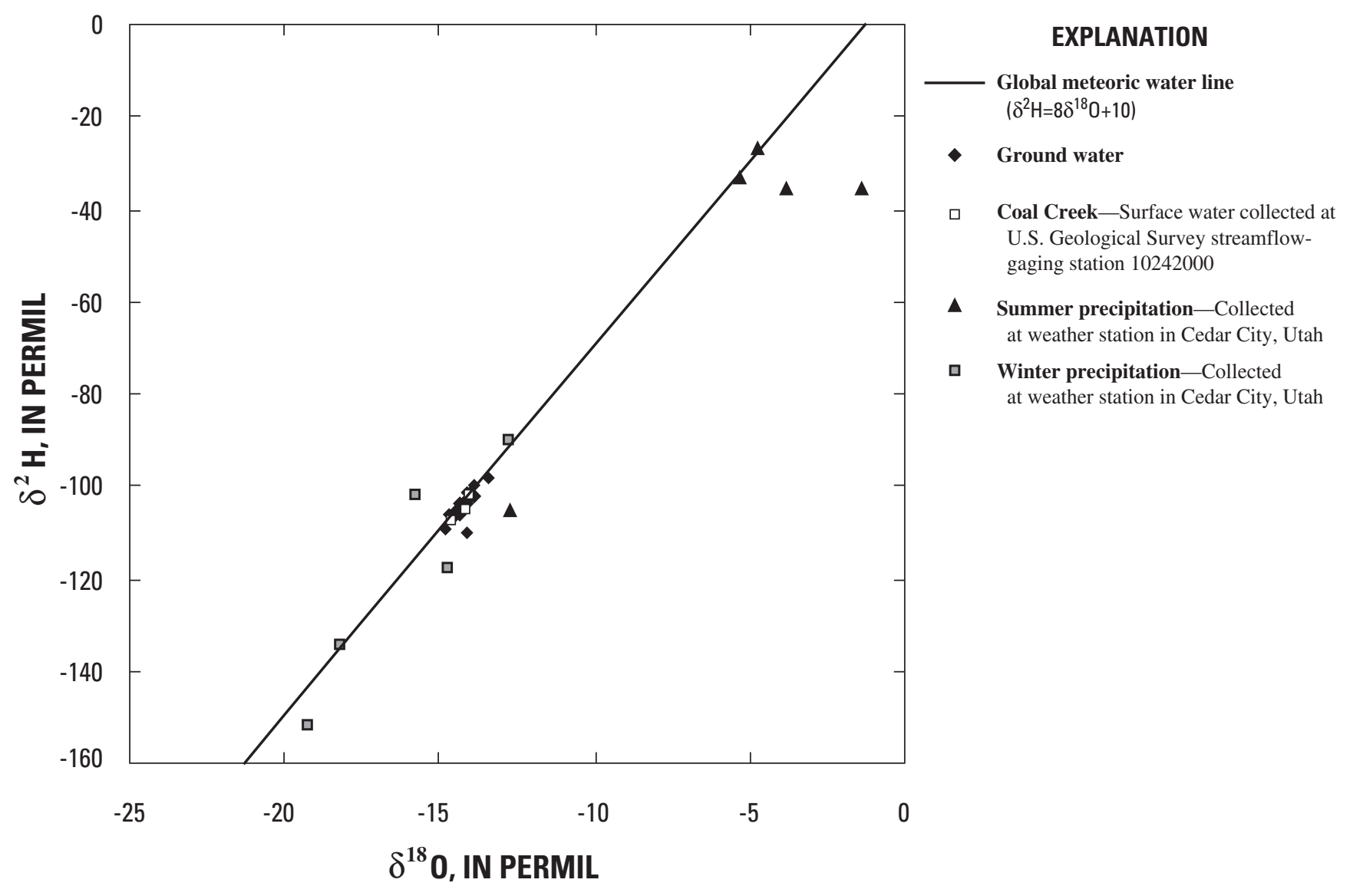

Figure 16. Relation between $\delta^{2} \mathrm{H}$ and $\delta^{18} \mathrm{O}$ values for ground-water, surface-water, and precipitation samples collected at selected sites, Cedar Valley, Iron County, Utah.

Chlorofluorocarbons (CFCs) are stable volatile organic compounds that are used as refrigerants, aerosol propellants, cleaning agents, and solvents. CFC-12 (dichlorodifluoromethane) was first produced in 1931, followed by CFC-11 (trichlorofluoromethane) in 1936 (Plummer and Busenberg, 2000, p. 441). Depending on how they are used, CFCs can be released to the atmosphere after 1 to more than 10 years (Plummer and Busenberg, 2000, p. 441). Although CFCs are nonflammable, nontoxic, and noncarcinogenic, they are one of the principal contributors to the depletion of the ozone layer (Plummer and Busenberg, 2000, p. 443). The use of CFCs on a worldwide basis, therefore, is being phased out.

By measuring the concentration of a particular $\mathrm{CFC}$ in ground-water samples, it is possible to determine an apparent date when the water entered the saturated zone of an aquifer. This is possible because the atmospheric mixing ratios for these CFCs are known for the past 50 years and the Henry's Law solubilities in water are also known (Plummer and Busenberg, 2000, p. 442). An apparent rather than an exact ground-water age is determined because many factors can affect the CFC concentrations of a sample when recharge water enters the saturated zone and during transport within the saturated zone. The solubility of CFCs in recharge water as it enters the saturated zone is dependent on the temperature of the water, known as recharge temperature, and, to a lesser degree, atmospheric pressure. These factors determine the initial CFC concentrations in ground water. If the ground-water flow path from the point of recharge to the sampling point is long, CFC concentrations may be altered by microbial degradation, sorption, hydrodynamic dispersion, and ground-water mixing. More detailed descriptions of dating ground water by using CFCs are reported in Busenberg and Plummer (1992) and Plummer and Busenberg (2000).

To prevent sample contamination by contact with the atmosphere, CFC samples were collected in copper tubes that were connected directly to the wells. Sample 
water was flushed through each copper tube for several minutes to prevent air bubbles from attaching to the inner wall. Trapped air in the sample contributes to an erroneous apparent age. Three samples were collected at each location to test reproducibility. A more detailed description of this collection method is presented in Wilkowske (1998, p. 8-13) and Heilweil and others (2000, p.13). Three of the four sampled wells are located along the eastern margin of the basin between Cedar City and Enoch with the fourth located just west of the airport (number 29 in fig. 11). The samples were analyzed for CFC-11 and CFC-12 at the University of Utah, Department of Geology and Geophysics Dissolved Gas Lab. CFC concentrations and apparent recharge date at different assumed recharge temperatures are presented in table 6.

The apparent ground-water recharge date is determined by calculating the CFC concentration in air that would be in equilibrium with the sample for the given recharge temperature and altitude. The calculated CFC concentration in air is then compared to the known historic atmospheric mixing ratios to determine the recharge date. For calculating recharge dates, recharge temperature was assumed to range from $0^{\circ} \mathrm{C}$, representative of air temperature during the winter, to $8^{\circ} \mathrm{C}$, representative of the approximate ambient air temperature. Atmospheric pressure is approximated in the calculation by using the average land-surface altitude of Cedar Valley. If recharge were assumed to occur at a higher altitude, such as the Markagunt Plateau to the east, the difference in altitude would result in a difference in apparent age of only about 1 year.

Water from well (C-35-10)18abc-1, a municipal well in Enoch, consistently had the oldest apparent ages of the sampled wells and had the smallest variation in dates determined by CFC-11 and CFC-12 (table 6). These apparent ages indicate a longer flow path and/or slower ground-water velocity than what is indicated by the apparent ages for water from the other wells. With its location along the eastern margin of the basin, the consolidated rock of the Markagunt Plateau may be the source of recharge for water withdrawn from well (C-3510)18abc-1, which would support the assumption of a long flow path.

Table 6. Chlorofluorocarbon concentration in ground-water samples and apparent recharge date for different assumed recharge temperatures, Cedar Valley, Iron County, Utah

[pmoles/kg, picomoles per kilogram; ${ }^{\circ} \mathrm{C}$, degrees Celsius; contaminated, chlorofluorocarbon $(\mathrm{CFC})$ concentration higher than expected in water in equilibrium with 1999 air]

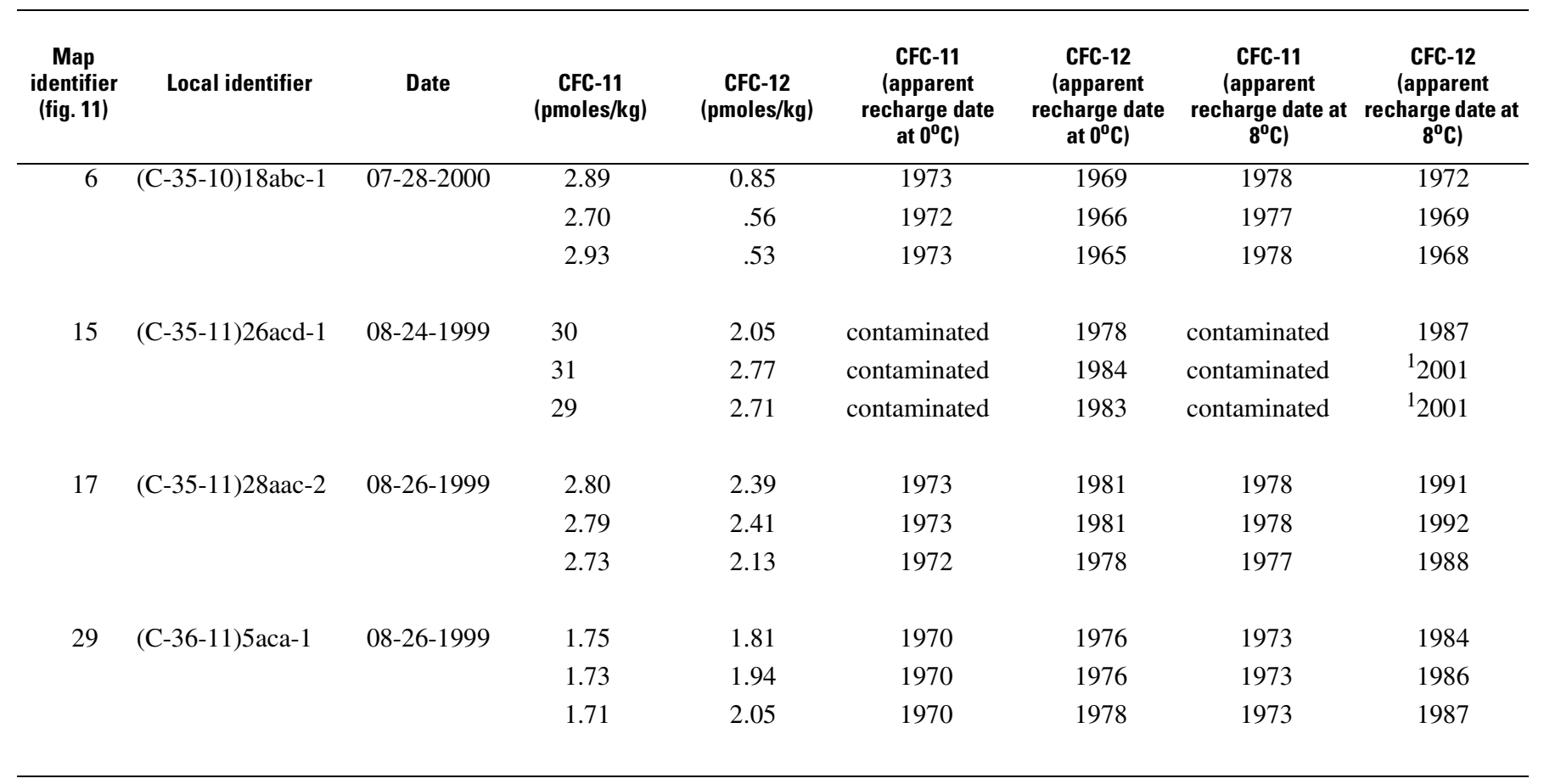

\footnotetext{
${ }^{1}$ Recharge date later than sample date.
} 
On the basis of CFC-12 concentration, the apparent ages for water from wells (C-35-11)26acd-1 and (C-3511)28aac-2 are the youngest of the four wells. This would indicate that the wells are relatively close to sources of recharge. Well (C-35-11)26acd-1 is located adjacent to an irrigation ditch and well (C-35-11)28aac-2 is located within an irrigated area. Samples from well (C-3511)26acd-1 were contaminated with respect to CFC-11. CFC-11 concentrations are higher than would be expected from atmospheric contamination during sampling. A likely source of contamination is from pump lubricating oil. Other possible sources of CFC-11 contamination could include point discharge from septic systems and leaking underground storage tanks as described by Plummer and Busenberg (2000, p. 456). In two of the three samples for well (C-35-11)26acd-1, CFC-12 concentrations were higher (table 6). These higher concentrations might be from an anthropogenic contamination source, similar to CFC-11. More likely, however, the higher concentrations are the result of trapped air in the sample. Under ideal conditions, apparent ages calculated from CFC-11 and CFC-12 concentrations should be nearly equivalent. A difference in apparent ages for water from all three wells, however, exists between CFC-11 and CFC-12. Physical and chemical processes, such as sorption, microbial degradation, and methanogenesis, as described by Plummer and Busenberg (2000, p. 457-461) may be responsible for lower CFC-11 concentrations and older apparent dates. Until more detailed data are collected to determine whether CFC-11 concentrations are reduced after recharge has occurred, apparent dates for CFC-12 should be considered more reliable.

Apparent ages for water from well (C-36-11)5aca1 , located west of the airport, at the distal end of the alluvial fan created by the Coal Creek drainage, are older than those from the two wells discussed previously. CFC11 concentrations are lower than those for CFC-12; therefore, the apparent ages for CFC-12 are considered more reliable. The older apparent ages indicate that water with drawn from this well either has a longer flow path from the source of recharge or flows through finer-grained unconsolidated basin fill.

A technique that involves tritium $\left({ }^{3} \mathrm{H}\right)$, helium-3 $\left({ }^{3} \mathrm{He}\right)$, and the dissolved gases nitrogen $\left(\mathrm{N}_{2}\right)$, argon (Ar), krypton $(\mathrm{Kr})$, neon $(\mathrm{Ne})$, and helium-4 $\left({ }^{4} \mathrm{He}\right)$ also was used to determine ground-water age and recharge temperature. During the 1950s and 1960s, large amounts of ${ }^{3} \mathrm{H}$ were released into the atmosphere and subsequently into the hydrologic cycle by above-ground thermonuclear weapons testing. As a result of large-scale tests during $1962-63,{ }^{3} \mathrm{H}$ concentration in precipitation peaked during
1963-64 at three orders of magnitude more than natural concentration (Michel, 1989). Since that period, ${ }^{3} \mathrm{H}$ has been used for ground-water age-dating and as a tracer. Tritium is a radioactive isotope of hydrogen and decays to ${ }^{3} \mathrm{He}$ with a half-life of 12.43 years. To effectively use ${ }^{3} \mathrm{H}$ for ground-water age dating, a realistic input function is required (Plummer and others, 1993, p. 258). Without knowing ${ }^{3} \mathrm{H}$ concentration versus age in recharge water, only ages relative to the peak ${ }^{3} \mathrm{H}$ concentrations can be determined. Descriptions for the use of ${ }^{3} \mathrm{H}$ for dating ground water are reported in Plummer and others (1993, p. 256-265) and Solomon and Cook (2000, p. 397-424).

Because transient ${ }^{3} \mathrm{H}$ peak concentrations in ground water from thermonuclear weapons testing are declining and ${ }^{3} \mathrm{H}$ input functions are difficult to determine, results from the ${ }^{3} \mathrm{H} /{ }^{3} \mathrm{He}$ age-dating method are more definitive than those from the method that only uses ${ }^{3} \mathrm{H}$. Helium-3 that is the product of ${ }^{3} \mathrm{H}$ decay is known as tritiogenic ${ }^{3} \mathrm{He}$. The initial ${ }^{3} \mathrm{H}$ concentration can be calculated if both ${ }^{3} \mathrm{H}$ and tritiogenic ${ }^{3} \mathrm{He}$ concentrations are determined and an age calculation can be made. On the basis of the ${ }^{3} \mathrm{H} /{ }^{3} \mathrm{He}$ concentration, age for a sample can be determined by the following equation (Solomon and Cook, 2000, p. 411):

$$
t=\lambda^{-1} \ln \left({ }^{3} H e_{\text {tritiogenic }}{ }^{\beta} H+1\right),
$$

where:

$$
\begin{aligned}
t & =\text { the apparent age in years; and } \\
\lambda & =\text { the decay constant for }{ }^{3} \mathrm{H} .
\end{aligned}
$$

The difficulty with the ${ }^{3} \mathrm{H} /{ }^{3} \mathrm{He}$ age-dating method is distinguishing between tritiogenic ${ }^{3} \mathrm{He}$ and other sources of ${ }^{3} \mathrm{He}$, such as from an atmospheric origin, nuclear reactions in the subsurface, and a mantle origin (Solomon and Cook, 2000, p. 411). Generally, tritiogenic and atmospheric ${ }^{3} \mathrm{He}$ are the only forms of ${ }^{3} \mathrm{He}$ in most ground water (D.K. Solomon, University of Utah, Dept. of Geology, written commun., 2003). By making this assumption, atmospheric ${ }^{3} \mathrm{He}$ can be estimated and that amount is subtracted from the measured total ${ }^{3} \mathrm{He}$ in a sample to obtain tritiogenic ${ }^{3} \mathrm{He}$. Atmospheric ${ }^{3} \mathrm{He}$ is divided into two components that are the amount based on equilibrium solubility with the atmosphere and the amount in excess air. Excess air is the amount of gas dissolved in water that is in excess of the amount based on equilibrium-solubility conditions. Atmospheric ${ }^{3} \mathrm{He}$ can be estimated on the basis of the measured Ne concentration in the sample. Dissolved-Ne gas in water is derived solely from an atmospheric source and its solubility in water is only slightly related to temperature. The measured Ne concentration is compared to its theoretical sol- 
ubility and any difference is attributed to $\mathrm{Ne}$ in excess air. Assuming that the ${ }^{3} \mathrm{He} / \mathrm{Ne}$ ratio is the same for excess air and the atmosphere, total atmospheric ${ }^{3} \mathrm{He}$ can be estimated. A similar method can be used with the other dissolved gases, $\mathrm{N}_{2}$, Ar, $\mathrm{Kr}$, and ${ }^{4} \mathrm{He}$. Because the equilibrium-solubility conditions for these gases depend more on temperature than does $\mathrm{Ne}$, recharge temperature can be estimated from the concentrations and estimated atmospheric pressure where recharge occurs. More detailed information for the ${ }^{3} \mathrm{H} /{ }^{3} \mathrm{He}$ age-dating method is provided in Solomon and Cook (2000) and for dissolved gases in Stute and Schlosser (2000).

Excess air in ground water may be the result of natural and/or anthropogenic factors. Wilson and McNeill (1997) suggested that the lithology of subsurface material in the recharge area and amount of precipitation can influence the amount of excess air. Stute and Schlosser (2000, p. 357) suggested that rising ground-water levels can entrain air from the unsaturated zone. Anthropogenic factors can include well development with compressed air, cavitation while pumping from a well, and sampling method. During this study, an in-situ diffusion sampler as described by Sheldon (2002) was used to collect samples for ${ }^{3} \mathrm{H} /{ }^{3} \mathrm{He}$ age dating and dissolved noble gas concentrations. Diffusion samplers are small copper tubes with attached gas-permeable silicon membranes. These samplers do not require pumping of water and therefore minimize the introduction of additional excess air during sampling. The diffusion samplers were placed at the depth of perforated zone for more than 12 hours before rapid removal and sealing of copper tubes. All samples were analyzed at the University of Utah Department of Geology and Geophysics Dissolved Gas Lab and results are presented in table 7.

Similar to the $\mathrm{CFC}$ data, ${ }^{3} \mathrm{H} /{ }^{3} \mathrm{He}$ data collected during this study are few and conclusions made from these data are not necessarily indicative of the entire study area. More ${ }^{3} \mathrm{H} /{ }^{3} \mathrm{He}$ data are needed before basinwide trends can be determined. The use of diffusion samplers for ${ }^{3} \mathrm{H} /{ }^{3} \mathrm{He}$ and dissolved-gas sampling would eliminate many of the problems encountered while collecting samples for CFC determination.

The three samples listed in table 7 were collected from monitoring wells that were completed as part of this study to examine water quality and water levels. Well (C$35-11) 25 \mathrm{bcc}-1$ is completed in the alluvial fan at the mouth of Fiddlers Canyon where ground water is under unconfined conditions. The ${ }^{3} \mathrm{H} /{ }^{3} \mathrm{He}$ age for water from this well is more than 45 years old and the recharge temperature is $0.0^{\circ} \mathrm{C}$ (table 7). Because of the low ${ }^{3} \mathrm{H}$ concentration and the lack of tritiogenic ${ }^{3} \mathrm{He}$, this water probably predates above-ground thermonuclear weapons testing. The low recharge temperature and the location of the well in close proximity to the Markagunt Plateau indicate that the source of recharge probably is snowmelt at higher altitudes on the plateau.

Wells (C-35-11)14bac-2 and (C-35-12)36caa-2 are completed in shallow zones in the center of the basin. Water from well (C-35-11) 14bac-2 has a ${ }^{3} \mathrm{H} /{ }^{3} \mathrm{He}$ age of more than 45 years. Similar to water from well (C-3511) 25 bcc-1, the lack of tritiogenic ${ }^{3} \mathrm{He}$ in this sample also indicates an age that predates above-ground thermonuclear weapons testing. The reported recharge temperature of $7.7^{\circ} \mathrm{C}$ for water from well (C-35-11)14bac-2 probably is indicative of some recharge occurring during the summer. The source of recharge probably is from surfacewater irrigation southeast of the well. The old groundwater age indicates that once the recharge water reaches the saturated zone, movement is very slow in the shallow zone. The slow movement is indicative of a small vertical hydraulic gradient and/or fine-grained unconsolidated basin fill.

The ${ }^{3} \mathrm{H} /{ }^{3} \mathrm{He}$ age for water from well (C-3512) $36 \mathrm{caa}-2$ is about 30 years and recharge temperature is $1.0^{\circ} \mathrm{C}$. The relatively young age, as compared to the previously mentioned shallow well, might be indicative of a nearby recharge source such as applied irrigation water. The low recharge temperature, however, indicates that the recharge source might be from winter precipitation or excess Coal Creek water that might have flowed in nearby ditches during the winter. The old ${ }^{3} \mathrm{H} /{ }^{3} \mathrm{He}$ ages for water from the two shallow wells indicate that recharge from applied irrigation water in the center of the basin takes considerably more time to reach deeper zones than irrigation water applied along the coarser unconsolidated basin fill along the eastern margin. More age data are needed to better understand recharge sources and timing for applied irrigation water throughout the basin.

\section{Nitrate-Source Determination}

Because nitrogen $(\mathrm{N})$ is prevalent and its conversion to nitrate $\left(\mathrm{NO}_{3}\right)$ is a common process in the environment, $\mathrm{NO}_{3}$ is probably the most widespread contaminant in ground water (Hallberg and Keeney, 1993, p. 297). Nitrate is very mobile in the environment, which makes it highly susceptible to leaching through soil. Nitrogen is an important component in protein and, therefore, is present in all animal waste (Hallberg and Keeney, 1993, p. 297). Because of these factors, $\mathrm{NO}_{3}$ can be derived from many natural and anthropogenic sources. Natural sources may include continuous $\mathrm{N}$ cycling in the 
Table 7. Dissolved gas, tritiogenic helium-3, and tritium concentrations, apparent age, and recharge temperature for ground-water samples collected from selected wells, Cedar Valley, Iron County, Utah

$\left[\mathrm{cm}^{3} \mathrm{STP} / \mathrm{g}\right.$, cubic centimeter of gas at standard temperature and pressure per gram of water; $\mathrm{R},{ }^{3} \mathrm{He} /{ }^{4} \mathrm{He}$ ratio in the sample; $\mathrm{R}_{\mathrm{a}},{ }^{3} \mathrm{He} /{ }^{4} \mathrm{He}$ ratio in the air standard; $\mathrm{TU}$, tritium unit; ${ }^{\circ} \mathrm{C}$, degrees Celsius; >, greater than]

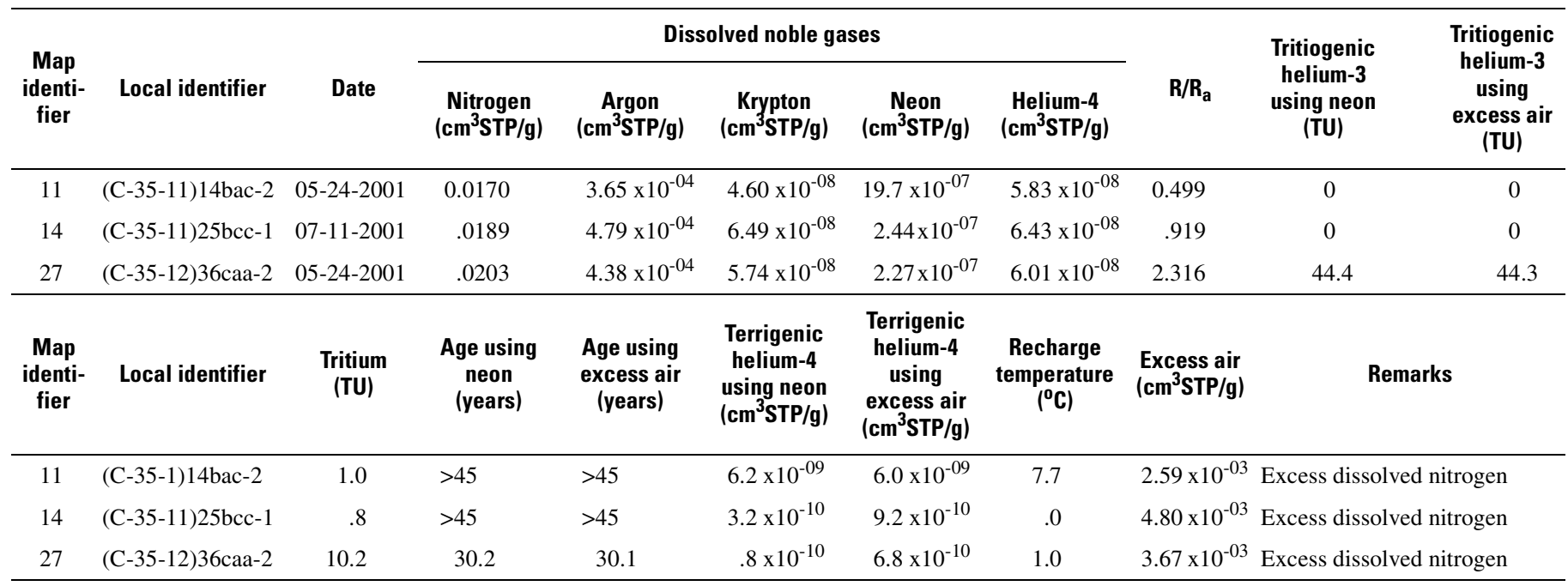

environment or water/rock interactions. Anthropogenic sources generally are the result of agricultural practices or disposal of organic waste. The intake of high levels of $\mathrm{NO}_{3}$ can result in health risks such as methemoglobinemia in infants (blue-baby syndrome), and Nnitroso compounds might function as initiators of human carcinogenesis (Kendall and Aravena, 2000, p. 261). Because of these health risks, the maximum permissible limit for $\mathrm{NO}_{3}$ (as $\mathrm{N}$ ) in drinking water has been set by the World Health Organization and the U.S. Environmental Protection Agency at $10 \mathrm{mg} / \mathrm{L}$ (Kendall and Aravena, 2000, p. 261).

Water-quality data reported by Thomas and Taylor (1946, p. 107-108) indicate that high $\mathrm{NO}_{3}$ concentrations in ground water have been present for more than 60 years. They reported $\mathrm{NO}_{3}$ (as $\mathrm{N}$ ) concentrations of greater than $10 \mathrm{mg} / \mathrm{L}$ in water collected from six wells that range in depth from 100 to $158 \mathrm{ft}$. The maximum reported $\mathrm{NO}_{3}$ (as $\mathrm{N}$ ) concentration was more than 58 $\mathrm{mg} / \mathrm{L}$. Five of the wells, located along the eastern margin of the basin, were completed in unconsolidated basin fill near Fiddlers Canyon. The sixth well was located near the south end of the present airport. Thomas and Taylor (1946, p. 110) attributed the high $\mathrm{NO}_{3}$ concentrations to possible contamination from soil organic matter or from mineral dissolution because of well depths and the associated high concentrations of sulfate and chloride relative to reported concentrations from other samples.
Sandberg (1963, table 4; and 1966, table 3) reported $\mathrm{NO}_{3}$ (as $\mathrm{N}$ ) concentrations of more than 10 $\mathrm{mg} / \mathrm{L}$ for water from two wells in Cedar Valley. These concentrations came from water in wells that are farther north and south than the area where Thomas and Taylor reported high $\mathrm{NO}_{3}$ concentrations. Bjorklund and others (1977, table 5) reported one $\mathrm{NO}_{3}$ (as $\mathrm{N}$ ) concentration that exceeded $10 \mathrm{mg} / \mathrm{L}$.

During 1979-81, 101 wells were sampled as part of a ground-water quality assessment (Joe Melling, City Manager, Cedar City, written commun., 1997). The range of concentrations for $\mathrm{NO}_{3}$ (as $\mathrm{N}$ ) in water from these wells was 0.06 to $57.4 \mathrm{mg} / \mathrm{L}$. The $\mathrm{NO}_{3}$ (as $\mathrm{N}$ ) concentration in water from 21 wells exceeded $10 \mathrm{mg} / \mathrm{L}$, and in water from 18 wells the concentration ranged from 5 to $10 \mathrm{mg} / \mathrm{L}$. No wells less than $100 \mathrm{ft}$ deep were sampled. About 30 wells were sampled seasonally during this period. Those wells that were sampled during January had lower $\mathrm{NO}_{3}$ concentrations than those sampled during the remainder of the year; otherwise, no seasonal trend or substantial variation was present. During 1999, the Utah Geological Survey collected water from 21 of the same wells that were sampled during 1979-81. The $\mathrm{NO}_{3}$ (as $\mathrm{N}$ ) concentration in these samples ranged from 1 to 23.1 $\mathrm{mg} / \mathrm{L}$ (Lowe and Wallace, 2001, p. 26).

During 1999-2001, the USGS collected water from 44 wells and 3 surface-water sites throughout most of Cedar Valley for chemical analysis in order to help determine temporal and spatial changes in ground-water qual- 
ity and identify possible $\mathrm{NO}_{3}$ source(s). Most of the wells sampled were used for irrigation. A few stock wells were sampled in the northern part of the basin where there are no irrigated fields. One well was being used as domestic supply for a small housing subdivision and three wells were completed as monitoring wells as part of this study. Two of the monitoring wells were completed in shallow zones and located adjacent to deep irrigation wells. The three surface-water samples were collected from one ephemeral and two perennial streams that drain the Markagunt Plateau along the eastern margin of Cedar Valley (fig. 11). Water samples collected from 15 wells with sufficient $\mathrm{NO}_{3}$ concentrations to meet sampling criteria were analyzed for ${ }^{15} \mathrm{~N}$ and ${ }^{18} \mathrm{O}$ isotopes in the $\mathrm{NO}_{3}$ anion to determine possible source(s).

The approximate spatial distribution for $\mathrm{NO}_{3}$ in ground water during the sampling period of this study (1999-2001) is shown in figure 17. The data are a compilation of $\mathrm{NO}_{3}$ concentrations determined from samples collected by the USGS and Utah Geological Survey (Lowe and Wallace, 2001, fig. 20). Other $\mathrm{NO}_{3}$ concentrations that were reported to the Utah Department of Environmental Quality, Division of Drinking Water, by municipalities or private water companies during this period are included in figure 17. In most of the southern, western, and northern parts of the valley, $\mathrm{NO}_{3}$ (as $\mathrm{N}$ ) concentrations are less than $1 \mathrm{mg} / \mathrm{L}$. The area along the eastern part of the valley from Cedar City north to Enoch had concentrations greater than $5 \mathrm{mg} / \mathrm{L}$. Water from well (C33-10)31ada-1, located about $8 \mathrm{mi}$ north of Enoch, outside of the high nitrate area, had a $\mathrm{NO}_{3}$ (as $\left.\mathrm{N}\right)$ concentration of more than $10 \mathrm{mg} / \mathrm{L}$. Three surface-water sites were sampled and the $\mathrm{NO}_{3}$ (as $\mathrm{N}$ ) concentrations were all less than $0.1 \mathrm{mg} / \mathrm{L}$.

Nitrate is the most stable form of $\mathrm{N}$ in the hydrologic environment. Different $\mathrm{N}$ sources may introduce $\mathrm{N}$ in other forms, which change to $\mathrm{NO}_{3}$ under aerobic (oxidizing) conditions. To examine whether $\mathrm{NO}_{3}$ is the most prevalent form of $\mathrm{N}$ in the ground-water system, selected samples were analyzed for other forms. In all of these samples, other forms of $\mathrm{N}$ were below detection limits or present in only trace amounts (table 8).

Nitrogen-15 and oxygen-18 isotopes in the nitrate anion were measured to determine possible nitrate sources and whether dentrification might be occurring. The $\delta$ value for nitrogen-15 $\left(\delta^{15} \mathrm{~N}\right)$ is calculated by using equation 4 in which the ${ }^{15} \mathrm{~N} /{ }^{14} \mathrm{~N}$ ratio is determined for the sample and referenced to the ${ }^{15} \mathrm{~N} /{ }^{14} \mathrm{~N}$ ratio for air, atmospheric nitrogen $\left(\mathrm{N}_{2}\right)$ (Kendall and Aravena, 2000, p. 262). Both $\delta^{15} \mathrm{~N}$ and $\delta^{18} \mathrm{O}$ values are determined for the $\mathrm{NO}_{3}$ anion because possible sources are more constrained than if only $\delta^{15} \mathrm{~N}$ values were reported.

Samples collected for ${ }^{15} \mathrm{~N}$ and ${ }^{18} \mathrm{O}$ analysis were concentrated in the field by using anion exchange resin columns as described by Silva and others (2000). The method for determining $\delta^{15} \mathrm{~N}$ and $\delta^{18} \mathrm{O}$ values in the $\mathrm{NO}_{3}$ anion also is described by Silva and others (2000). Through various biogeochemical processes within the hydrologic environment, $\delta^{15} \mathrm{~N}$ and $\delta^{18} \mathrm{O}$ values are affected when $\mathrm{N}$ cycles from one form to another. A summary of these processes and how $\delta^{15} \mathrm{~N}$ values are affected is described in Kendall (1998) and Kendall and Aravena (2000).

The $\delta^{15} \mathrm{~N}$ and $\delta^{18} \mathrm{O}$ values in $\mathrm{NO}_{3}$ for samples collected during this study are shown in figure 18 and plot within ranges for three possible sources that include ammonium $\left(\mathrm{NH}_{4}\right)$ in fertilizer and rain, manure and septic waste, and soil N. Because no single source can be identified as the cause for elevated nitrate concentrations in ground water, other chemical, hydrologic, and land-use factors must be incorporated into the nitrate-source determination.

To help determine possible nitrate source(s), $\delta^{15} \mathrm{~N}$ values are plotted in relation to the potentiometric surface for 2000 (fig. 19). Direction of ground-water flow, landuse practices, and geology can all be used to help identify possible sources, which may include upwelling fluid along faults, leaching of nitrogen-bearing minerals in consolidated rocks within the Markagunt Plateau and from the basin-fill material derived from these rocks, soil nitrogen, or anthropogenic sources such as septic systems and agricultural practices.

Upwelling fluid along the eastern basin-bounding faults (Hurlow, 2002, fig. 10) appears to be an unlikely source for most of the $\mathrm{NO}_{3}$ in ground water. Temperature, major-ion chemistry, and ${ }^{18} \mathrm{O}$ and ${ }^{2} \mathrm{H}$ isotopes in samples collected from wells with elevated $\mathrm{NO}_{3}$ concentrations are not significantly different than in samples with low nitrate concentrations. More importantly, elevated nitrate concentrations are present in water from wells located upgradient from these faults, such as wells (C-35-11)25bcc-1 and (C-35-11)26acd-1. Also, water from well (C-35-11)26acd-1was dated by using CFCs and had an apparent age of 1978 (table 6), which is probably too young for deep circulation. 


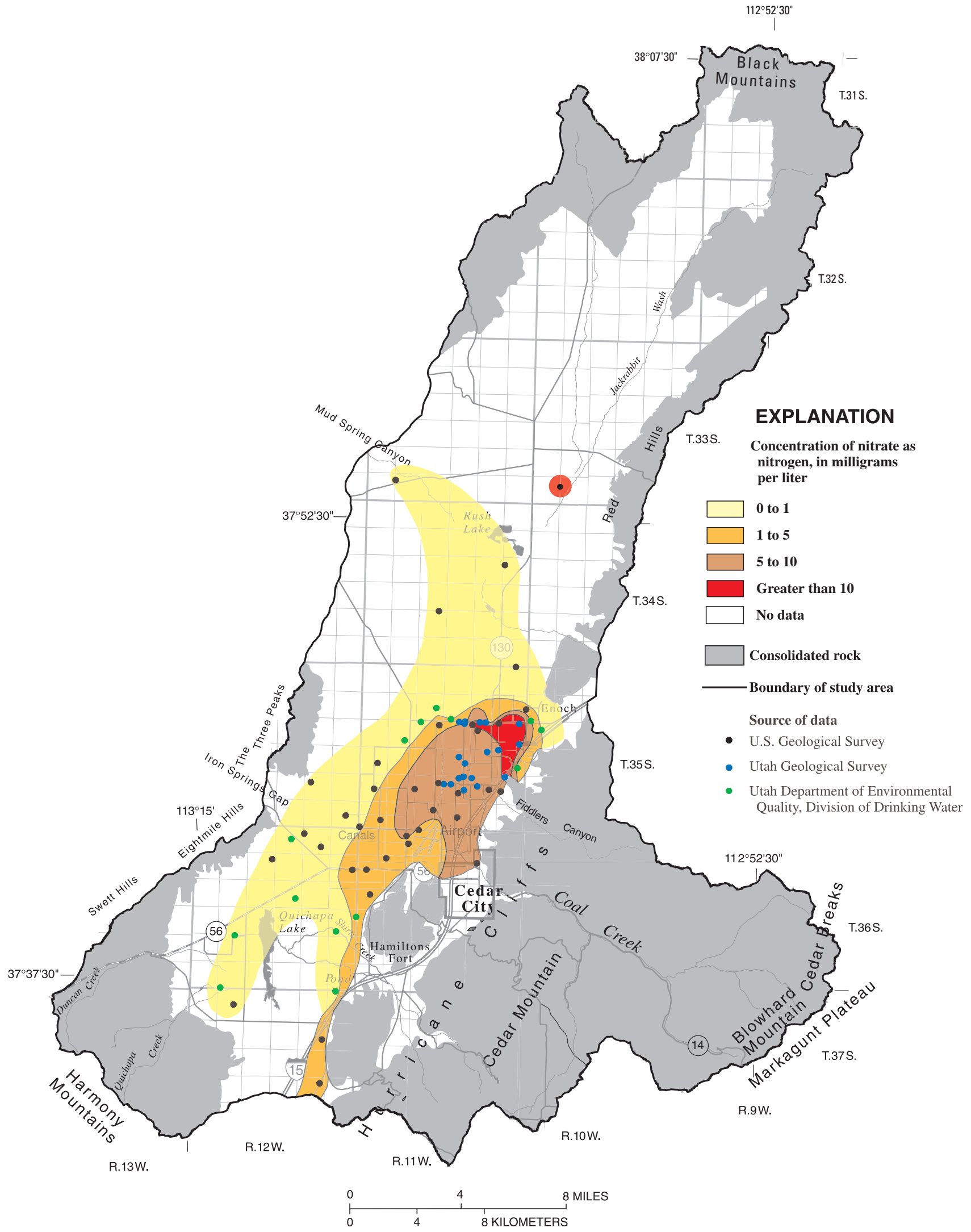

Figure 17. Approximate distribution for nitrate concentration in water collected from selected wells, 1999-2001, Cedar Valley, Iron County, Utah. 
Table 8. Concentration of dissolved nitrogen species and nitrogen and oxygen isotope ratios in the nitrate anion for water samples collected from selected sites, Cedar Valley, Iron County, Utah

[mg/L, milligrams per liter; permil, parts per thousand; —, no data available; <, less than; E, estimated]




Table 8. Concentration of dissolved nitrogen species and nitrogen and oxygen isotope ratios in the nitrate anion for water samples collected from selected sites, Cedar Valley, Iron County, Utah—Continued

\begin{tabular}{|c|c|c|c|c|c|c|c|}
\hline $\begin{array}{c}\text { Local } \\
\text { identifier }\end{array}$ & Date & $\begin{array}{l}\text { Nitrogen, } \\
\text { ammonia, } \\
\text { dissolved } \\
\text { (mg/L } \\
\text { as N) }\end{array}$ & $\begin{array}{c}\text { Nitrogen, } \\
\text { ammonia + } \\
\text { organic, } \\
\text { dissolved } \\
\text { (mg/L as N) }\end{array}$ & $\begin{array}{c}\text { Nitrogen, } \\
\text { nitrite + nitrate, } \\
\text { dissolved } \\
\text { (mg/L as N) }\end{array}$ & $\begin{array}{c}\text { Nitrogen, } \\
\text { nitrite, } \\
\text { dissolved } \\
\text { (mg/L as N) }\end{array}$ & $\begin{array}{c}\delta^{15} \mathbf{N} \\
\left(\mathrm{NO}_{3}\right) \\
\text { (permil) }\end{array}$ & $\begin{array}{c}\delta^{18} \mathbf{0} \\
\left(\mathrm{NO}_{3}\right) \\
\text { (permil) }\end{array}$ \\
\hline$\overline{(C-36-11) ~ 5 d a b-1}$ & 09-01-99 & - & - & 3.52 & - & - & - \\
\hline$(\mathrm{C}-36-11) 7 \mathrm{aaa}-2$ & 09-01-99 & - & - & 3.95 & - & 7.8 & -.68 \\
\hline (C-36-11) 7cab-1 & 08-23-99 & - & .25 & 4.41 & .013 & - & - \\
\hline \multirow[t]{2}{*}{ (C-36-11)11bac-1 } & 08-26-99 & - & - & 6.48 & - & 7.46 & 2.07 \\
\hline & $07-25-00$ & - & - & 6.51 & - & - & - \\
\hline (C-36-11)18bdd-1 & 07-22-99 & - & - & 4.05 & - & - & - \\
\hline (C-36-11)31abc-1 & $07-28-00$ & $<.02$ & $<.10$ & 7.50 & $<.010$ & 4.2 & 8.25 \\
\hline (C-36-12) 2dbc-1 & $07-21-99$ & - & - & .43 & - & - & - \\
\hline (C-36-12) 3aad-2 & $07-21-99$ & - & - & .61 & - & - & - \\
\hline (C-36-12) 9aac-1 & $07-21-99$ & - & - & .39 & - & - & - \\
\hline (C-36-12)12dba-1 & 08-23-99 & - & .15 & 1.49 & $<.010$ & - & - \\
\hline \multirow[t]{2}{*}{ (C-36-12)36adb-1 } & 07-22-99 & - & - & 1.95 & - & - & - \\
\hline & $07-25-00$ & - & - & 1.98 & - & - & - \\
\hline (C-37-12) 5acc-2 & 08-23-99 & - & E.09 & .999 & $<.010$ & - & - \\
\hline (C-37-12)11dac-1 & 08-23-99 & - & .21 & 1.06 & $<.010$ & - & - \\
\hline (C-37-12)23abd-1 & 07-13-99 & - & - & 2.96 & - & - & - \\
\hline Coal Creek & $07-27-99$ & - & - & .07 & - & - & - \\
\hline Coal Creek & $03-16-00$ & - & - & .16 & - & - & - \\
\hline Coal Creek & $06-13-00$ & - & - & $<.05$ & - & - & - \\
\hline$(\mathrm{C}-35-11) 36 \mathrm{bac}$ & $07-27-99$ & - & - & $<.05$ & - & - & - \\
\hline (C-36-11)31bda & 07-15-99 & - & - & .09 & - & - & - \\
\hline
\end{tabular}

Leaching of nitrogen-bearing minerals in consolidated rocks in the Markagunt Plateau or in unconsolidated basin fill derived from adjacent consolidated rocks may be possible; nitrogen has been detected in solidphase samples collected from outcrops of the Cretaceousage Straight Cliffs Formation in Fiddlers Canyon (Lowe and Wallace, 2001, p. 34). The $\delta^{15} \mathrm{~N}$ values from these consolidated-rock samples were $0.6 \%$ for calcareous sandstone facies and $3.0 \%$ for silty sandstone facies. Because of the type of process used for determining $\delta^{15} \mathrm{~N}$ values in solid-phase samples, $\delta^{18} \mathrm{O}$ values are not determined. The $\delta^{15} \mathrm{~N}$ values in water from wells (C-3511)25bcc-1, 26acd-1, 33abd-1, and 33ccd-1 (1.76\% \% $3.59 \%, 3.87 \%$, and $2.48 \%$, respectively) are reasonably close to the values for the solid-phase samples (table 8). The $\delta^{15} \mathrm{~N}$ values in water from these wells support the concept presented by Lowe and Wallace (2001) that nitrogen-bearing minerals in the consolidated rocks are an important source for nitrate in ground water. These values also are indicative of ammonia in fertilizer (fig. 18 , , but virtually all agricultural land is in alfalfa production with applications of low-nitrogen fertilizer. Fertilizer applied to alfalfa typically contains 90 percent phosphorous with only 5 percent nitrogen and 5 percent potassium (Chad Reid, County Extension agent, oral commun., 2002). Although not definitive, the lack of phosphorous in ground water (Howells and others, 2002, table 4) may indicate that applied fertilizers do not contribute to the chemical composition of ground water. The relatively young CFC age dates in two wells that are adjacent to irrigated fields indicate possible rapid recharge.

This recharge could only come from seepage of irrigation canals and ditches and irrigated fields. All other $\delta^{15} \mathrm{~N}$ values approach the range for manure and septic waste or soil nitrogen. These values indicate possible mixing of the consolidated rock or natural source with manure, septic waste, or soil nitrogen. 


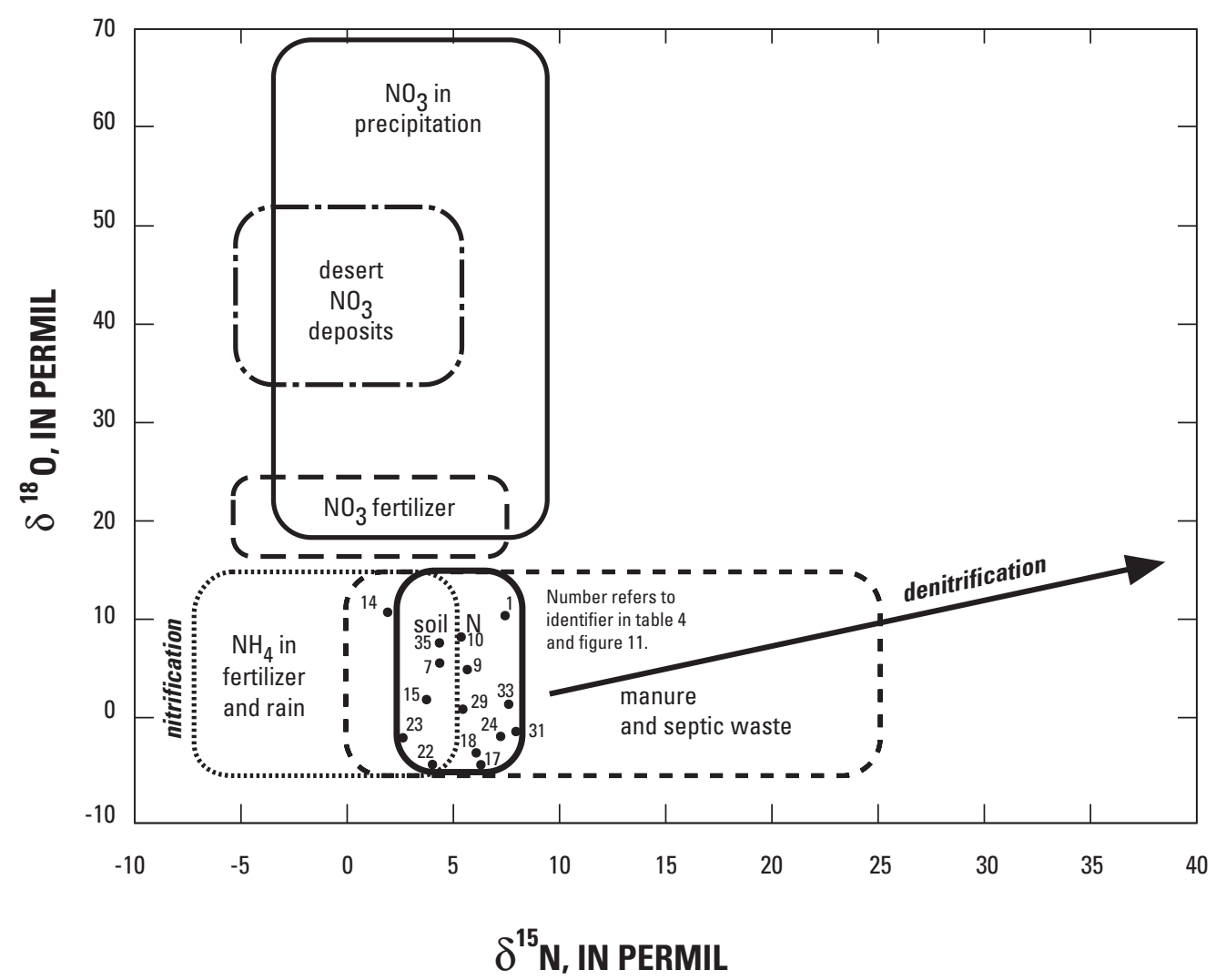

Figure 18. Relation of $\delta^{15} \mathrm{~N}$ and $\delta^{18} 0$ values in the nitrate anion for water collected from selected wells, Cedar Valley, Iron County, Utah, to the range of those values for various nitrogen sources.

(Modified from Kendall, 1998.)

A waste-water effluent source is possibly prevalent in specific areas. From the mid-1930s, when sewer lines were completed in Cedar City, to 1976 sewage was spread over the land surface just south and east of the airport (Joe Melling, City Manager, Cedar City, oral commun., 2002). This area is located at the distal end of the alluvial fan created by the Coal Creek drainage. Although no drillers' logs are available for this area, nearby commercial gravel pits indicate that medium- to coarsegrained unconsolidated basin fill suitable for recharge is prevalent. Water from well (C-36-11)7aaa-2, located about $1.5 \mathrm{mi}$ west and downgradient of this area, was collected for chemical analysis. Although the $\mathrm{NO}_{3}$ (as $\mathrm{N}$ ) concentration of $3.95 \mathrm{mg} / \mathrm{L}$ (table 8 ) is less than the limit of $10 \mathrm{mg} / \mathrm{L}$ for drinking water, it is substantially higher than concentrations for water samples collected from wells to the west (fig. 17). The $\delta^{15} \mathrm{~N}$ value of $7.80 \%$ is the highest of all values obtained during this study and indicates probable recharge from waste water that was applied to the area south and east of the airport or from septic systems in the nearby subdivision. The well has a depth of $300 \mathrm{ft}$ but the perforated interval is unknown (Howells and others, 2002, table 1).

Effluent from an obsolete waste-water treatment plant located about 1 mi northeast of the airport was applied to irrigated fields to the north during 1976-96 (Joe Melling, City Manager, Cedar City, oral commun., 2002). Samples were collected from three wells that are located in the vicinity of this waste-water treatment plant or near the area where effluent was applied to irrigated fields. These wells include (C-35-11)27dbb-1 located 1 mi directly north, (C-35-11)28acc-2 located about $1.5 \mathrm{mi}$ northwest, and (C-35-11)34dbb-1 located adjacent to the waste-water treatment plant. In these samples, there is a direct correlation between $\mathrm{NO}_{3}$ (as $\mathrm{N}$ ) concentration and $\delta^{15} \mathrm{~N}$ values such that higher $\mathrm{NO}_{3}$ (as $\mathrm{N}$ ) concentrations correspond to higher $\delta^{15} \mathrm{~N}$ values. This pattern indicates that waste-water effluent probably is recharging the ground-water system in this area. 


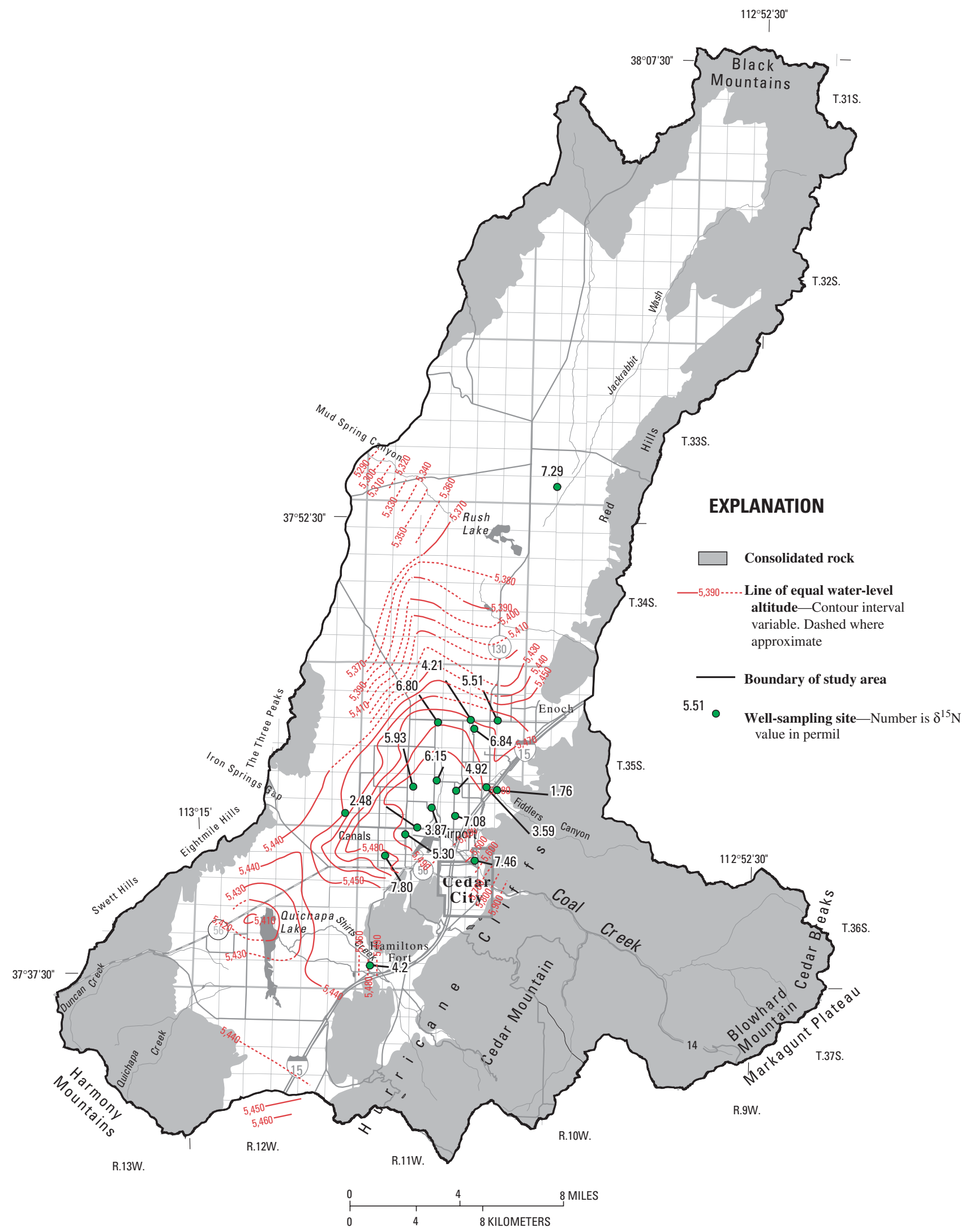

Figure 19. Relation between $\delta^{15} \mathrm{~N}$ values in the nitrate anion for water collected from selected wells and the approximate potentiometric surface for March 2000 in Cedar Valley, Iron County, Utah. 
Despite being directly north of the waste-water treatment plant near where the effluent was applied, water from well (C-35-11)27dbb-1 had the lowest $\mathrm{NO}_{3}$ (as N) concentration of $3.03 \mathrm{mg} / \mathrm{L}$ and lowest $\delta^{15} \mathrm{~N}$ value of $4.92 \%$. These values indicate that little effluent reaches the ground-water system here or that it is diluted by other water with low $\mathrm{NO}_{3}$ concentration. Water from well (C-35-11)28aac-2 has a $\mathrm{NO}_{3}$ (as $\mathrm{N}$ ) concentration of $5.18 \mathrm{mg} / \mathrm{L}$ and a $\delta^{15} \mathrm{~N}$ value of $6.15 \%$ that would indicate possible recharge from applied effluent. Well (C-3511)28aac- 2 is located hydraulically downgradient from the point of application. This well has a depth of $354 \mathrm{ft}$ but the perforated interval is unknown (Howells and others, 2002, table 1). If the perforated interval includes shallow zones, this well could capture recharge from effluent when pumped. The highest $\mathrm{NO}_{3}$ (as $\mathrm{N}$ ) concentration of $8.98 \mathrm{mg} / \mathrm{L}$ and highest $\delta^{15} \mathrm{~N}$ value of $7.08 \%$ for these wells was in water from well (C-35-11)34dbb-1. This well, located adjacent to the obsolete waste-water treatment plant, has a depth of $152 \mathrm{ft}$ and the perforated interval is unknown (Howells and others, 2002, table 1). Because many of the wells in the study area are perforated throughout much of the well depth, the casing in this well also may be perforated in shallow zones that are more susceptible to local recharge. Although this well is not located in the area where effluent was applied to irrigated fields, some of the water captured by this well might contain effluent that could have leaked from process ponds. An alternative source for some of the $\mathrm{NO}_{3}$ in water from this well might be to the southeast and hydraulically upgradient where water from well (C-3611)11 bac-1 has a similar $\delta^{15} \mathrm{~N}$ value but a lower $\mathrm{NO}_{3}$ (as N) concentration.

Well (C-36-11)11bac-1 is located in Cedar City. Because of high dissolved-solids concentration (Howells and others, 2002, table 4), the water from this well is used primarily for municipal irrigation. The $\mathrm{NO}_{3}$ (as $\mathrm{N}$ ) concentration was $6.51 \mathrm{mg} / \mathrm{L}$ (August 26, 1999) and the $\delta^{15} \mathrm{~N}$ value was $7.46 \%$ (table 8 ). The $\delta^{15} \mathrm{~N}$ value is the highest of any values for water from wells located in proximity to the Markagunt Plateau on the east side of the basin (fig. 19). The high $\delta^{15} \mathrm{~N}$ value indicates that the nitrate source(s) for water in well (C-36-11)11bac-1 could be a mixture of nitrogen derived from consolidated rock and sewage prior to development of city infrastructure, or from nitrification of soil nitrogen. Because of the well configuration, attempts to date the age of this water by using CFCs were not successful. Knowing the relative age for this water would have been helpful to determine whether there is a component that predates the construction of sewers in Cedar City.
Water was collected from shallow monitoring wells (C-35-11)14bac-2 and (C-35-12)36caa-2 for chemical analysis in order to examine possible nitrate sources in shallow zones. The $\mathrm{NO}_{3}$ (as $\mathrm{N}$ ) concentration in water from well (C-35-11)14bac-2 was very low (less than 0.04 $\mathrm{mg} / \mathrm{L}$ ), whereas the concentration in water from well (C35-12)36caa-2 was $2.67 \mathrm{mg} / \mathrm{L}$ (table 8). Dissolved-gas analysis for ${ }^{3} \mathrm{H} /{ }^{3} \mathrm{He}$ age dating indicates the presence of a dissolved $\mathrm{N}_{2}$ gas concentration in water from both wells that is higher than the concentration expected for equilibrium solubility with the atmosphere and in excess air (table 6). Excess dissolved $\mathrm{N}_{2}$ gas in ground water is indicative of denitrification. This is a multi-step process by which $\mathrm{NO}_{3}$ is transformed into dissolved $\mathrm{N}_{2}$ under specific geochemical conditions. Because the dissolvedsolids concentrations in water from both wells were high, $\delta^{15} \mathrm{~N}$ values could not be determined by using the sampling and analytical methods mentioned previously in this section. Although these data indicate that $\mathrm{NO}_{3}$ derived from near-surface sources might be reduced through the natural process of denitrification at these locations, it is unknown whether this process may be occurring in shallow zones throughout the basin. More data need to be collected to determine the spatial distribution of conditions where denitrification may be occurring.

Historical and recent $\mathrm{NO}_{3}$ data from which direct comparisons can be made are limited. Many of the wells with water that had high $\mathrm{NO}_{3}$ concentrations reported by Thomas and Taylor (1946, p. 107-108) and Joe Melling (City Manager, Cedar City, written commun., 1997) are no longer in use and could not be sampled during this study. Many of the wells with previously reported low $\mathrm{NO}_{3}$ concentrations, however, could be resampled. Additional wells not previously sampled for $\mathrm{NO}_{3}$ concentrations were sampled to obtain a wide spatial distribution.

Lowe and Wallace (2001, p. 26) resampled 21 wells in 1999 that originally were sampled during 197981. The concentration in water from 13 wells, for the most part, remained the same, whereas the concentration in water from 5 wells declined. Lowe and Wallace (2001) concluded that $\mathrm{NO}_{3}$ concentrations in the Enoch area remained relatively constant from 1979 to 1999 . Data reported to the Utah Department of Environmental Quality, Division of Drinking Water (Tim Pine, written commun., 2002) indicate that $\mathrm{NO}_{3}$ concentrations in water from public-supply wells have remained relatively constant. Where variations in $\mathrm{NO}_{3}$ concentrations for water from some wells do exist, it is unclear whether these variations represent a change in the spatial distribution of $\mathrm{NO}_{3}$ or are the result of a change in a well pump- 
ing level. Because of lowered ground-water levels, a decrease in $\mathrm{NO}_{3}$ concentration could be the result of withdrawal from production zones with lower $\mathrm{NO}_{3}$ concentrations. Conversely, a slight increase in $\mathrm{NO}_{3}$ concentration might result from withdrawal from zones with higher $\mathrm{NO}_{3}$ concentrations and/or anthropogenic causes such as mixing with waste-water effluent. Despite these variations, the spatial distribution of ground water with elevated $\mathrm{NO}_{3}$ concentrations in the area near Enoch and south along the eastern margin of the basin does not appear to be migrating beyond its previously known extent.

The apparent lack of $\mathrm{NO}_{3}$ migration in the principal aquifer probably can be attributed to natural and anthropogenic processes. As shown by dissolved-gas data (table 7) obtained from the two shallow monitoring wells, denitrification might be occurring where appropriate conditions exist. Except where mixing with waste-water effluent might have occurred, $\delta^{15} \mathrm{~N}$ values in water from wells toward the northwest generally are higher than those in water from wells closer to the eastern margin of the basin. During the denitrification process, the $\delta^{15} \mathrm{~N}$ value in the residual $\mathrm{NO}_{3}$ increases exponentially (Kendall and Aravena, 2000, p. 271). The $\delta^{15} \mathrm{~N}$ values in water from wells to the northwest are almost twice as large, which could have resulted from denitrification. Low ground-water velocities also may contribute to the lack of distinguishable migration of elevated $\mathrm{NO}_{3}$ concentrations because of the relatively short time (about 20 years) between sampling periods. Large ground-water withdrawals from irrigation wells likely intercept the flow of water downgradient from areas with elevated $\mathrm{NO}_{3}$ concentrations. More data need to be collected to verify whether the lack of apparent $\mathrm{NO}_{3}$ migration can be attributed to these possible causes.

\section{Chloride Mass Balance}

Conservative chemical constituents such as bromide $(\mathrm{Br})$ and chloride $(\mathrm{Cl})$ are useful environmental tracers that can be used to better understand hydrologic processes in Cedar Valley. Both $\mathrm{Br}$ and $\mathrm{Cl}$ are highly soluble and mobile and are not involved in common geochemical reactions that occur in aquifers (Herczeg and Edmunds, 2000, p. 38). Because $\mathrm{Br}$ and $\mathrm{Cl}$ are conservative and remain in solution when water evaporates or is transpired by plants, these constituents become more concentrated in the residual solution in proportion to the amount of water removed (Herczeg and Edmunds, 2000, p. 39). As water moves downward beyond the root zone, the $\mathrm{Cl}$ concentration is carried to the saturated zone unchanged and can be used to estimate recharge from precipitation.

The chloride mass-balance method has been used successfully for estimating recharge in arid and semi-arid environments. Explanations and derivation of the chloride mass-balance method are presented by Wood and Sanford (1995, p. 460) and Herczeg and Edmunds (2000, p. 39). Recharge to the ground-water system from precipitation can be quantified with the chloride mass-balance method by the following equation:

$$
Q=(P)\left(C l_{p}\right) / C l_{g w}
$$

where:

$$
\begin{aligned}
Q & =\text { ground-water recharge flux, in acre-ft/yr; } \\
P & =\text { precipitation, in acre- } \mathrm{ft} / \mathrm{yr} ; \\
C l_{p} & =\text { weighted average chloride concentration } \\
& \text { (wet and dry) in precipitation, in } \mathrm{mg} / \mathrm{L} ; \text { and } \\
C l_{g w} & =\text { chloride concentration in ground water, in } \\
& \mathrm{mg} / \mathrm{L} .
\end{aligned}
$$

Application of the $\mathrm{Cl}$ mass-balance method includes the following assumptions as paraphrased from Wood and Sanford (1995, p. 460) and Wood (1999, p. 2): (1) the only source of $\mathrm{Cl}$ in ground water is from precipitation falling directly on the aquifer material; (2) concentration of $\mathrm{Cl}$ in ground water is by evapotranspiration within the unsaturated zone, not from recycling, dissolution of minerals containing $\mathrm{Cl}$, or inflow from adjacent aquifers; (3) $\mathrm{Cl}$ is conservative in the ground-water system; and (4) the $\mathrm{Cl}$ mass flux has not changed over time. Assumptions (1) and (2) are violated in Cedar Valley; the following paragraphs explain how the mass-balance method was adjusted to account for these violations. Chloride probably is conservative in the ground-water system and the mass flux has probably not changed substantially over time. Sequential core samples were not collected to determine $\mathrm{Cl}$ concentration profiles with increasing depth in the unsaturated zone. Any change in $\mathrm{Cl}$ mass flux over time, therefore, could not be verified.

Bromide and $\mathrm{Cl}$ concentrations in ground-water, surface-water, and precipitation samples collected during this study (fig. 20) were examined to determine whether or not ground water is enriched with $\mathrm{Cl}$ from sources other than precipitation. If $\mathrm{Cl}$ is enriched with respect to $\mathrm{Br}$ in ground water within the unconsolidated basin fill, then there is a probable geologic source for the higher $\mathrm{Cl}$ concentrations such as dissolution of evaporites within the Mesozoic-age sedimentary rock formations that crop out in the Markagunt Plateau. Bromide concentration will not increase from the dissolution of evaporites because 


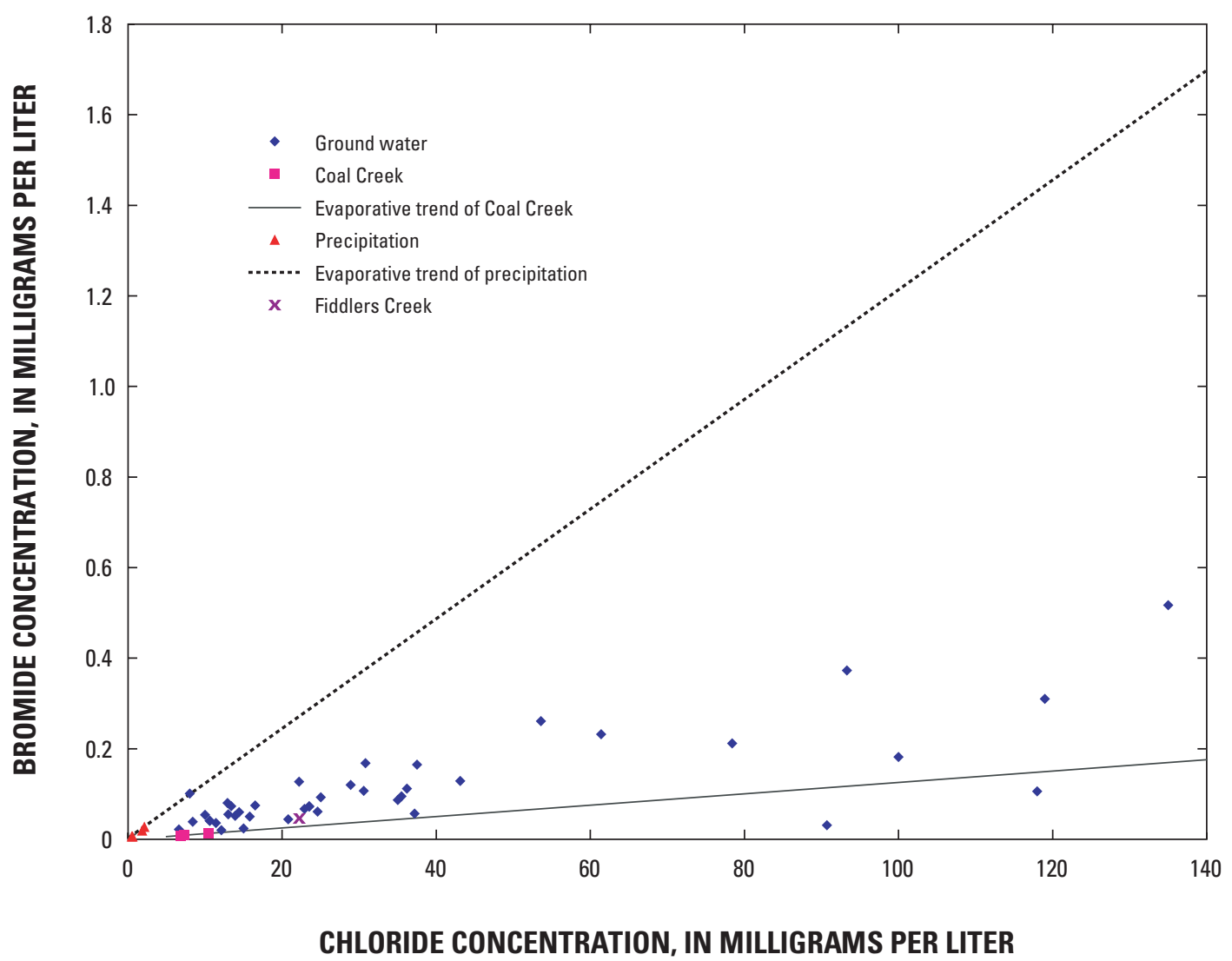

Figure 20. Relation of bromide to chloride concentrations in ground-water, surface-water, and precipitation samples, Cedar Valley, Iron County, Utah.

mineral precipitation out of solution that contains $\mathrm{Br}$ requires a much higher density than the point at which halite $(\mathrm{NaCl})$ or gypsum $\left(\mathrm{CaSO}_{4}\right)$, the two most common evaporite minerals, would form (Herczeg and Edmunds, 2000, p. 42). It is also possible that the $\mathrm{Cl}$ enrichment is caused by sorbtion of $\mathrm{Br}$ by organic material (Davis and others, 1998, p. 340).

Concentrations for $\mathrm{Br}$ and $\mathrm{Cl}$ from ground- and surface-water samples collected during this study are reported in Howells and others (2002, table 4). Bromide and $\mathrm{Cl}$ concentrations were determined for five precipitation samples. Because of the low $\mathrm{Br}$ and $\mathrm{Cl}$ concentrations in precipitation, these samples were analyzed at Los Alamos National Laboratory in Los Alamos, New Mexico, and are reported in the following table. The precipitation sample collected on July 9, 2001, has a $\mathrm{Cl}: \mathrm{Br}$ ratio that is extremely high in comparison to the ratio in other samples. It is possible that this sample accumulated $\mathrm{Cl}$ from playa dust or another local source and that its concentration is not representative of average precipitation.
The average $\mathrm{Cl}$ and $\mathrm{Br}$ concentration from the other four samples are $1.25 \mathrm{mg} / \mathrm{L}$ and $0.015 \mathrm{mg} / \mathrm{L}$, respectively. The average $\mathrm{Cl}: \mathrm{Br}$ ratio is 82.6 .

\begin{tabular}{cccc}
\hline $\begin{array}{c}\text { Date of } \\
\text { precipitation } \\
\text { sample }\end{array}$ & $\begin{array}{c}\text { Chloride } \\
\text { concentration } \\
\text { (milligrams per } \\
\text { liter) }\end{array}$ & $\begin{array}{c}\text { Bromide } \\
\text { concentration } \\
\text { (milligrams } \\
\text { per liter) }\end{array}$ & $\begin{array}{c}\text { Cl:Br } \\
\text { ratio }\end{array}$ \\
\hline $05-17-2001$ & 0.481 & 0.00658 & 73.2 \\
$05-28-2001$ & 1.824 & .01984 & 91.9 \\
$06-26-2001$ & 2.110 & .02766 & 76.3 \\
$07-05-2001$ & .589 & .00661 & 89.1 \\
$07-09-2001$ & 2.867 & .01008 & 285 \\
\hline
\end{tabular}

Concentration by evapotranspiration of precipitation or water in Coal Creek would increase $\mathrm{Br}$ and $\mathrm{Cl}$ concentrations but not change the $\mathrm{Cl}: \mathrm{Br}$ ratio (fig. 20). Because recharge from Coal Creek is a source of $\mathrm{Cl}$ to the ground-water system, it will be added to the massbalance equation. The samples collected from Coal Creek are more enriched in $\mathrm{Cl}$ with respect to $\mathrm{Br}$ than the sam- 
ples collected from precipitation. The average $\mathrm{Cl}$ and $\mathrm{Br}$ concentrations from Coal Creek are $8.2 \mathrm{mg} / \mathrm{L}$ and 0.01 $\mathrm{mg} / \mathrm{L}$, respectively. The average $\mathrm{Cl}: \mathrm{Br}$ ratio is 798 . This indicates a probable geologic source of $\mathrm{Cl}$ in the Coal Creek drainage basin. Although the three samples from Coal Creek were collected during the months of March, June, and July, streamflow was only slightly greater than base flow and ranged from 20 to $22 \mathrm{ft}^{3} / \mathrm{s}$. During snowmelt runoff when surface runoff far exceeds base flow in Coal Creek, the water might not be as enriched in $\mathrm{Cl}$ and, therefore, would be closer to the $\mathrm{Cl}$ : $\mathrm{Br}$ ratio of precipitation.

Most of the samples collected from wells have $\mathrm{Cl}: \mathrm{Br}$ ratios between the ratios for precipitation and Coal Creek, indicating that recharge is a combination of those two sources, or of sources with similar $\mathrm{Cl}$ : $\mathrm{Br}$ ratios. Subsurface inflow from consolidated rock could have a $\mathrm{Cl}: \mathrm{Br}$ ratio similar to that of precipitation or similar to that of Coal Creek. Because the ratio is unknown, the mass-balance method will assume that subsurface inflow has the same ratio as precipitation. The mass of $\mathrm{Cl}$ in precipitation in the mountains is assumed to contribute to the mass of $\mathrm{Cl}$ recharging the ground-water system. Precipitation in the Coal Creek drainage is not included in the calculation because the $\mathrm{Cl}$ is included in the flow in Coal Creek.

Two samples collected from wells have $\mathrm{Cl}: \mathrm{Br}$ ratios that exceed the ratio of samples from Coal Creek, indicating a possible other source of $\mathrm{Cl}$ in the groundwater system. One of these samples is from well (C-3311)31aad-1 near Mud Springs Canyon and one is from well (C-35-11)34dbb-1 just north of Cedar City in an area irrigated with water from Coal Creek. The source of $\mathrm{Cl}$ near Cedar City may be an obsolete waste-water treatment plant located adjacent to well (C-35-11)34dbb-1. Davis and others (1998, p. 345) report that the high $\mathrm{Cl}: \mathrm{Br}$ ratio of sewage makes identification possible. The source of $\mathrm{Cl}$ in these two wells is assumed to be a negligible part of the $\mathrm{Cl}$ mass-balance calculation.

Samples collected from wells north of Enoch generally have high $\mathrm{Br}$ and $\mathrm{Cl}$ concentrations and show prominent $\mathrm{Cl}$ enrichment with respect to $\mathrm{Br}$. Wells in this area are located at sufficient distance from irrigation ditches so as not to be influenced by water derived from Coal Creek. The high $\mathrm{Br}$ and $\mathrm{Cl}$ concentrations are probably the result of recycling of irrigation water derived from areas upgradient of these wells. $\delta^{18} \mathrm{O}$ and $\delta^{2} \mathrm{H}$ values in samples collected from wells do not indicate a major shift from precipitation as would occur if recycling of ground water was a major component of the system.

Therefore, $\mathrm{Cl}$ applied during irrigation with ground water is assumed to equal $\mathrm{Cl}$ removed from the system by with- drawal for irrigation, and neither is used in the $\mathrm{Cl}$ massbalance calculation. Chloride removed from the system from domestic wells returns to the system through septic systems, irrigation of lawns, or irrigation with wastewater treatment-plant effluent, and is not included in the mass-balance calculation.

Inflow from Parowan Valley is a small part of the ground-water budget and probably not a major source of $\mathrm{Cl}$. For the mass-balance calculations, inflow of $\mathrm{Cl}$ from Parowan Valley was assumed to equal outflow of $\mathrm{Cl}$ through Mud Springs Canyon and Iron Springs Gap.

For the $\mathrm{Cl}$ mass-balance calculations in Cedar Valley, adding Coal Creek water and precipitation on the mountains accounts for $\mathrm{Cl}$ in ground water that is not from direct precipitation on the valley or that flows in from adjacent aquifers in the consolidated rock. The revised $\mathrm{Cl}$ mass-balance equation can be written:

$$
Q C l_{g w}=P C l_{p}+C C l_{c}
$$

where:

$$
\begin{aligned}
Q= & \text { recharge flux, in acre-ft } / \mathrm{yr} ; \\
C l_{g w}= & \text { average concentration of } \mathrm{Cl} \text { in ground water }= \\
& 37 \mathrm{mg} / \mathrm{L} ; \\
P \quad= & \text { precipitation on valley and mountains exclud- } \\
& \text { ing the Coal Creek drainage }=398,000 \text { acre- } \\
& \mathrm{ft} / \mathrm{yr} ; \\
C l_{p}= & \text { concentration of } \mathrm{Cl} \text { in precipitation }=1.25 \\
& \mathrm{mg} / \mathrm{L} ; \\
C \quad= & \text { annual flow in Coal Creek }=24,200 \text { acre- } \\
& \mathrm{ft} / \mathrm{yr} \text {; and } \\
C l_{c}= & \text { concentration of } \mathrm{Cl} \text { in Coal Creek }=8.2 \mathrm{mg} / \mathrm{L} .
\end{aligned}
$$

Recharge from precipitation and Coal Creek calculated by using the above equation and values is 18,800 acre$\mathrm{ft} / \mathrm{yr}$. This is substantially less than the amount calculated by using other methods of about 35,000 acre-ft/yr for the predevelopment budget and 30,000 acre-ft/yr for 2000 . Because the mass-balance calculation is based on limited $\mathrm{Cl}$ concentration data for precipitation and Coal Creek, it should be considered a rough approximation. The recharge rate determined by using equation 8 is very sensitive to the average $\mathrm{Cl}$ concentrations. For example, a $0.1 \mathrm{mg} / \mathrm{L}$ change in $\mathrm{Cl}$ concentration in precipitation changes the recharge by 1,100 acre-ft/yr. A $1 \mathrm{mg} / \mathrm{L}$ change in $\mathrm{Cl}$ concentration in ground water or Coal Creek changes the recharge by $500 \mathrm{acre}-\mathrm{ft} / \mathrm{yr}$ and 600 acre-ft/yr, respectively. More data on $\mathrm{Cl}$ concentration, especially in precipitation, would minimize the error in this method. 


\section{Numerical Simulation of Ground-Water Flow in the Unconsolidated Basin Fill}

A numerical ground-water flow model was developed to simulate the ground-water system in the unconsolidated basin fill in Cedar Valley and to test the conceptual understanding of the ground-water system. Development of the model included compilation and examination of water-level, streamflow, and groundwater withdrawal data and estimation and spatial distribution of recharge, discharge, hydraulic conductivity, and specific yield. Both a steady-state and a transient model were developed. The "Recharge from irrigation" section of this report discusses how the model was used to test and change the conceptual understanding of recharge from irrigation in Cedar Valley. The "Model construction" section discusses the details of discretization, boundary conditions, and model parameters. The "Calibration" section discusses how the model was changed to match observed data and how adequately the model simulates the ground-water system.

The ground-water flow model was constructed using MODFLOW-2000, (Harbaugh and others, 2000; and Hill and others, 2000). The terms "observed" and "observation" are used to define water-level and discharge data used as observations in the ground-water flow model (Hill and others, 2000, p. 23). The term "measured water level" refers to known levels that may or may not be included as observations. Because of numerical instability near pumping wells during the transient simulation, the vertical-flow correction in MODFLOW-2000 (Harbaugh and others, 2000, p. 31) was removed (McAda and Baroll, 2002). The vertical-flow correction improves simulation accuracy when part of the simulated system is perched, but can cause numerical instability resulting in solution failure. At the end of the transient simulation, perched conditions exist in two model cells at different locations in the model. The minor inaccuracy caused by deactivating the vertical-flow correction is considered negligible.

\section{Recharge from Irrigation}

Recharge from irrigation was estimated outside of MODFLOW-2000 and input to MODFLOW-2000 as areal recharge using the Recharge Package (Harbaugh and others, 2000, p. 67). The method of determining recharge from irrigation was changed during the calibration process as explained in the following sections.

\section{Recharge during 1938-49}

Recharge from irrigation during 1938-49 initially was assumed to occur evenly over all irrigated areas with 50 percent of the applied water becoming ground-water recharge as explained in the "Recharge" section of this report. Because recharge from individual canals is poorly defined, canal recharge was assumed to be distributed over the irrigated area and is included in the model with recharge from irrigation. Recharge from irrigation with ephemeral streams was considered negligible. The total $17,600 \mathrm{acre}-\mathrm{ft} / \mathrm{yr}$ of recharge from irrigation was applied evenly over the 14,100 acres estimated to be irrigated during 1938-49 (fig. 21) for an average recharge rate of $1.25 \mathrm{ft} / \mathrm{yr}$. The irrigated area was estimated on the basis of November 1960 aerial photographs obtained from the U.S. Forest Service Geometronics Service Center, Salt Lake City, Utah.

During calibration of the steady-state model, however, water levels could not be adequately simulated with this recharge method, and sensitivity analysis indicated that the simulated levels were very sensitive to recharge from irrigation. The inability of the model to simulate water levels indicated that the conceptual understanding of recharge should be reevaluated. A new method to distribute recharge on the basis of the Coal Creek Decree (described in the "Surface water" section of this report) was developed (table 9). First, for each month, the distribution of Coal Creek water to water rights Class 1, 2, 3, $4 \mathrm{a}$, and low priority was determined. Second, the area irrigated with surface water was divided into seven irrigation areas (fig. 22) and the monthly amount of surface water each area received based on its water rights was determined. Fifty percent of the water delivered during the growing season was assumed to become groundwater recharge except in the City area where 47 percent was assumed because urban development causes increased runoff. Seepage from Coal Creek was included in the City area. All of the water delivered during the winter was assumed to recharge the ground-water system. As determined from water rights (Utah Department of Natural Resources, Division of Water Rights, 2001), more irrigation may be provided by Shirts and Murie Creeks than was originally estimated. The estimated recharge in these areas was the average of the recharge in other irrigation areas not including the City area. Recharge from irrigation with surface water is more than what was calculated with the original method, mainly because of accounting differences and the addition of water supplied from Shirts and Murie Creeks. 


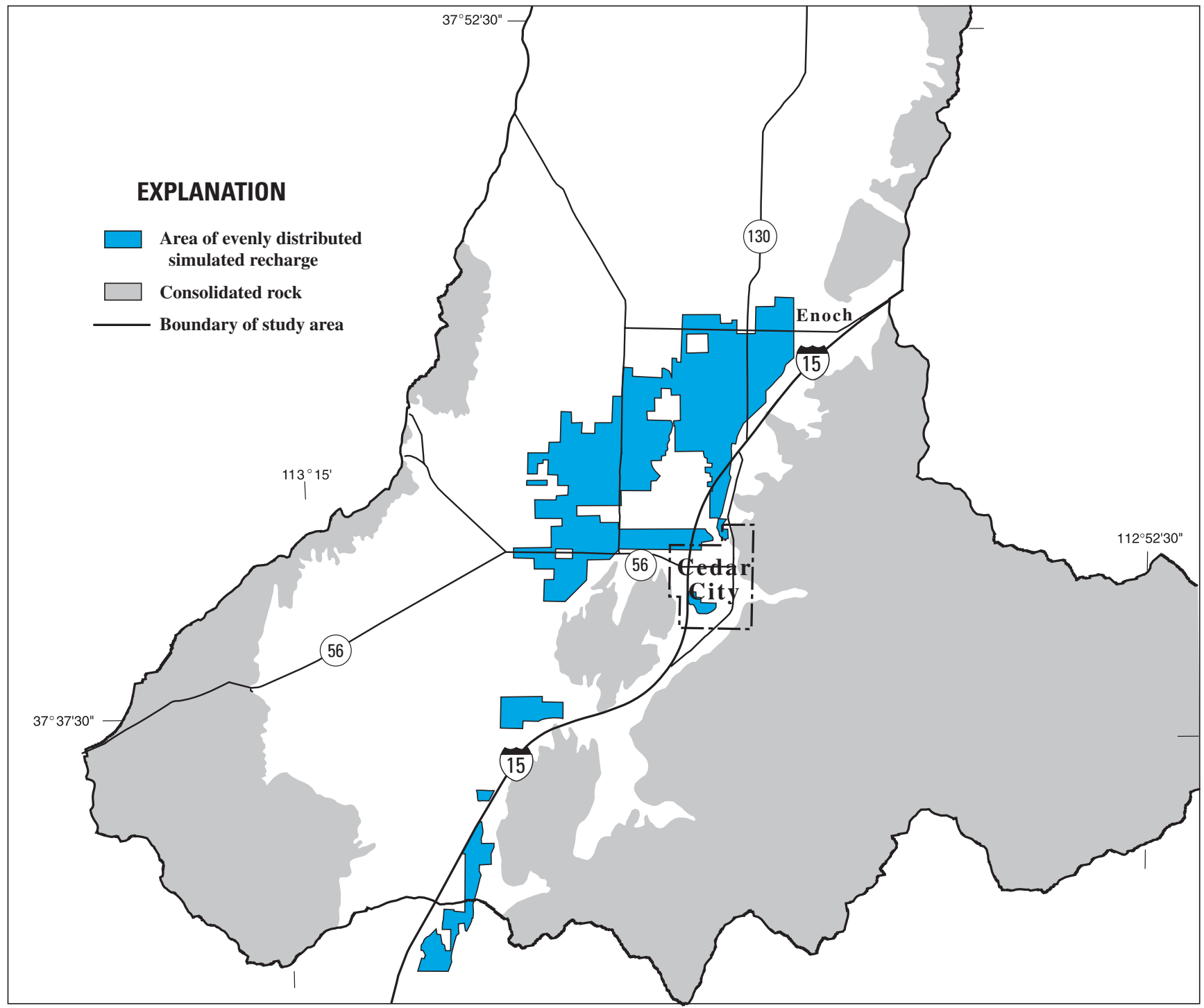

Base from U.S. Geological Survey digital data, 1982, 1:100,000 Universal Transverse Mercator projection, Zone 12

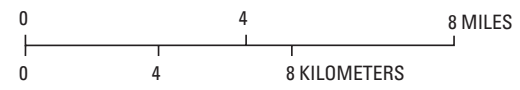

Figure 21. Area of estimated evenly distributed recharge from irrigation, Cedar Valley, Iron County, Utah. 
Table 9. Conceptual annual recharge from irrigation with surface water and seepage from Coal Creek, Cedar Valley, Iron County, Utah, 1938-49

[Area includes enclosed non-irrigation areas and is greater than actual irrigated area. Summer extra water refers to water available when flow in Coal Creek exceeds 102.02 cubic feet per second. Water applied during the winter was determined by proportioning flow in Coal Creek by area. Total recharge (acre-feet): Total summer applied multiplied by summer recharge percent plus winter applied plus seepage from Coal Creek; Total recharge (feet): Total recharge (acre-feet) divided by area; - - not applicable]

\begin{tabular}{|c|c|c|c|c|c|c|c|c|c|}
\hline \multirow{2}{*}{$\begin{array}{l}\text { Surface-water } \\
\text { irrigation area } \\
\text { (fig. 22) }\end{array}$} & \multirow{2}{*}{$\begin{array}{c}\text { Area } \\
\text { (acres) }\end{array}$} & \multirow{2}{*}{$\begin{array}{c}\text { Summer } \\
\text { water right } \\
\text { (acre-feet) }\end{array}$} & \multirow{2}{*}{$\begin{array}{c}\text { Summer extra } \\
\text { water } \\
\text { (acre-feet) }\end{array}$} & \multirow{2}{*}{$\begin{array}{l}\text { Total summer } \\
\text { applied } \\
\text { (acre-feet) }\end{array}$} & \multirow{2}{*}{$\begin{array}{l}\text { Summer } \\
\text { recharge } \\
\text { percent }\end{array}$} & \multirow{2}{*}{$\begin{array}{c}\text { Winter } \\
\text { applied } \\
\text { (acre-feet) }\end{array}$} & \multirow{2}{*}{$\begin{array}{l}\text { Seepage from } \\
\text { Coal Creek } \\
\text { (acre-feet) }\end{array}$} & \multicolumn{2}{|c|}{ Total recharge } \\
\hline & & & & & & & & (acre-feet) & (feet) \\
\hline City & 2,367 & 7,281 & 628 & 7,909 & 47 & 260 & 2,450 & 6,427 & 2.72 \\
\hline North Field & 2,333 & 4,741 & 619 & 5,359 & 50 & 256 & - & 2,936 & 1.26 \\
\hline Union & 1,715 & 2,781 & 455 & 3,236 & 50 & 188 & - & 1,806 & 1.05 \\
\hline 4a only & 1,775 & 2,406 & 471 & 2,877 & 50 & 195 & - & 1,633 & 0.92 \\
\hline Low rights & 9,510 & 186 & 0 & 186 & 50 & 1,043 & - & 1,137 & 0.12 \\
\hline $\begin{array}{c}\text { Shirts and } \\
\text { Murie } \\
\text { Creeks }\end{array}$ & 2,887 & - & - & - & - & - & - & 1,415 & 0.49 \\
\hline $\begin{array}{l}\text { Total } \\
\quad \text { (rounded) }\end{array}$ & 20,600 & 17,400 & 2,200 & 19,600 & - & 1,900 & 2,400 & 15,400 & - \\
\hline
\end{tabular}

Recharge from irrigation with ground water also was changed. Water was assumed to be applied to fields near each well in the 17 ground-water irrigation areas (fig. 23 and table 10) used during 1938-49. Recharge during 1938-49 for each of these areas is listed in table 10 .

The steady-state model was changed to incorporate the areal variability in recharge, which caused simulated water levels to more closely match observed levels. This indicates that the new concept of variable recharge is probably more accurate than the concept of evenly distributed recharge.

\section{Recharge during 1950-2000}

The amount of water applied to each irrigation area changes dramatically with flow in Coal Creek. The distribution of Coal Creek to the irrigation areas for selected years was determined by using records of flow in Coal Creek and the Coal Creek Decree. These years were used to develop equations to calculate the amount of water applied to each irrigation area for the remaining years of the transient simulation. The amount of water applied from wells also changes during the 63-year transient simulation. Two methods were used to determine recharge from irrigation and Coal Creek. Recharge for selected years determined by those two methods is presented in table 11 and the methods are described in the following sections.

\section{Percent-Recharge Method}

In the first method used to estimate recharge from surface-water irrigation, a specified percentage of applied water was assumed to become ground-water recharge. In most areas, the percent of applied water that becomes ground-water recharge gradually was decreased from 50 percent to represent conversion of many areas from flood irrigation to sprinkler irrigation. To represent land-use changes and urbanization around Cedar City, recharge was gradually reduced from 47 percent to 20 percent of applied surface water. As with the 1938-49 calculations, all streamflow during the non-irrigation season and all seepage from Coal Creek was assumed to become ground-water recharge.

Irrigation with ground water was assigned to 31 areas during 1950-2000 (fig. 23). The percentage of applied water that becomes ground-water recharge for each area was assumed to decline from 50 percent for 1938-65 to 20 to 30 percent in 2000 because of the change to sprinkler irrigation. Recharge from groundwater irrigation with this method ranged from 5,900 acreft for 1987 and 1988 to 13,400 acre-ft for 1970-74. 


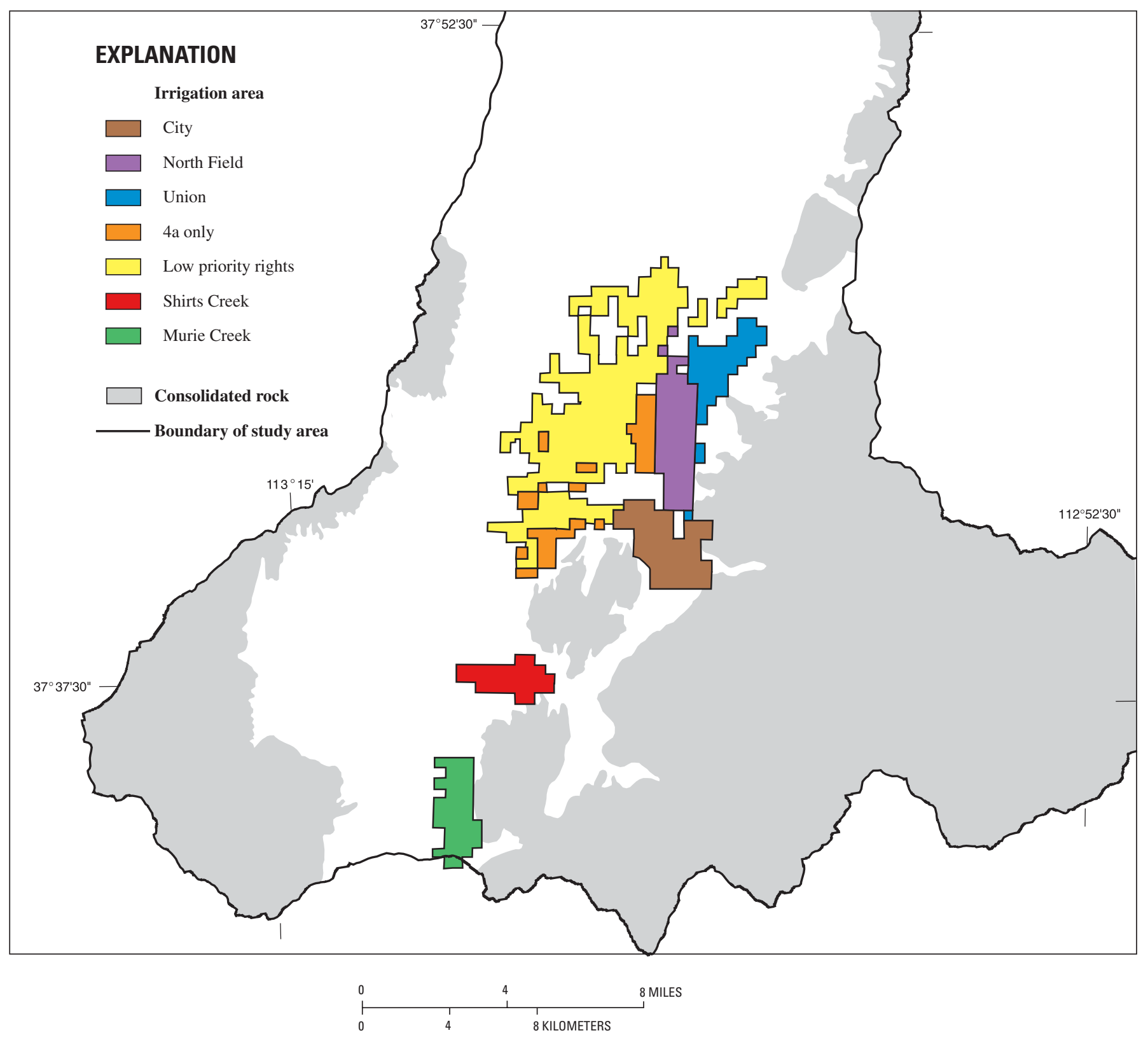

Figure 22. Surface-water irrigation areas, Cedar Valley, Iron County, Utah. 


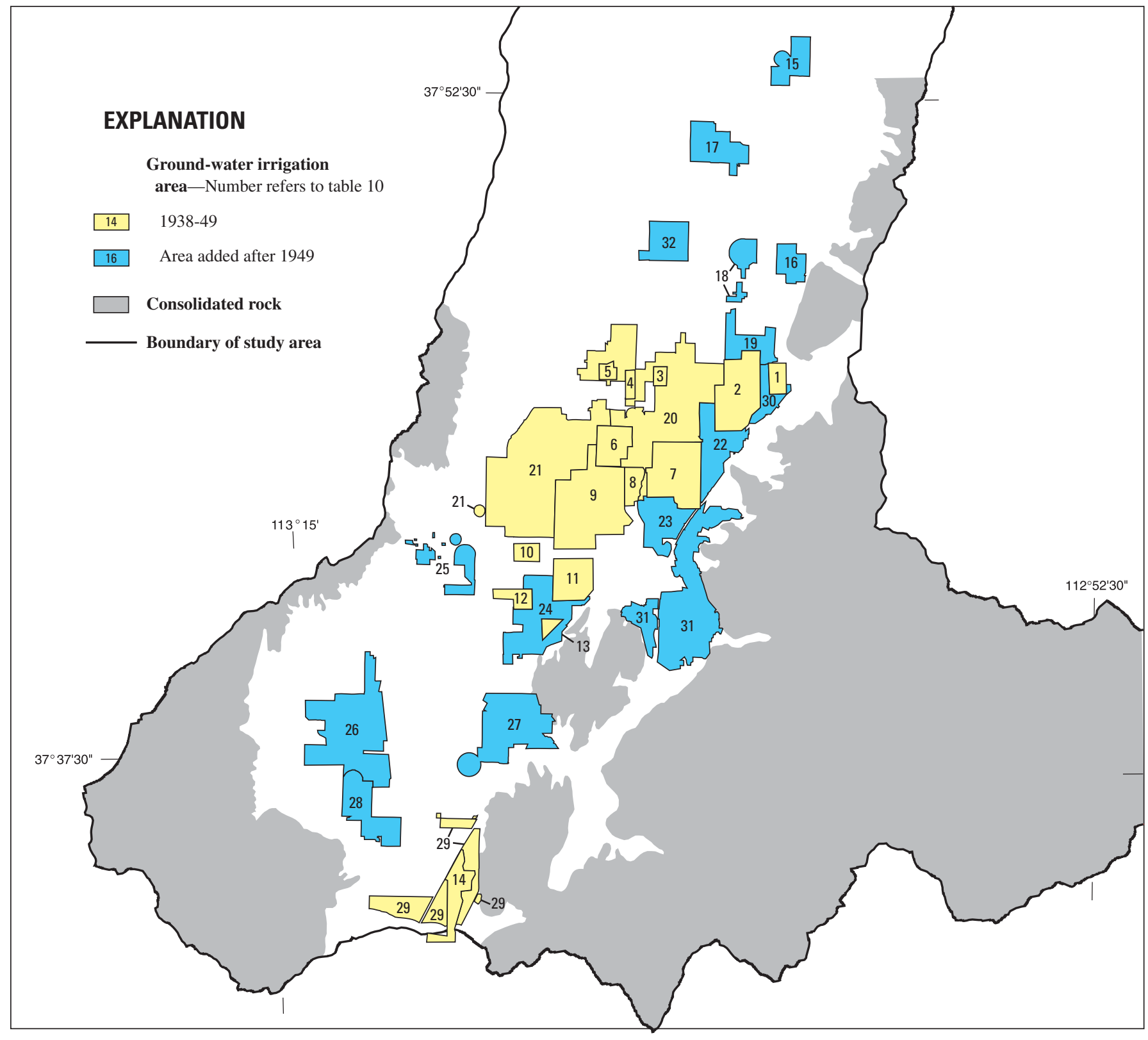

Base from U.S. Geological Survey digital data, 1982, 1:100,000 Universal Transverse Mercator projection, Zone 12

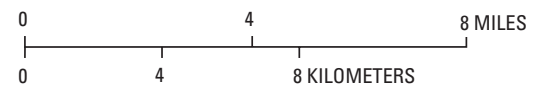

Figure 23. Ground-water irrigation areas, Cedar Valley, Iron County, Utah. 
Table 10. Conceptual annual recharge from irrigation with ground water, Cedar Valley, Iron County, Utah, 1938-49

[Ground-water areas 15-19, 22-28, 30, 31 not irrigated with ground water during 1938-49; - , not applicable]

\begin{tabular}{|c|c|c|c|}
\hline \multirow{2}{*}{$\begin{array}{l}\text { Ground-water } \\
\text { irrigation area } \\
\text { (fig. 23) }\end{array}$} & \multirow{2}{*}{$\begin{array}{c}\text { Area } \\
\text { (acres) }\end{array}$} & \multicolumn{2}{|c|}{ Recharge } \\
\hline & & (acre-feet) & (feet, rounded) \\
\hline 1 & 223 & 174 & 0.78 \\
\hline 2 & 1,228 & 719 & .59 \\
\hline 3 & 105 & 62 & .59 \\
\hline 4 & 114 & 122 & 1.07 \\
\hline 5 & 112 & 40 & .35 \\
\hline 6 & 536 & 395 & .74 \\
\hline 7 & 1,301 & 1,405 & 1.08 \\
\hline 8 & 258 & 219 & .85 \\
\hline 9 & 2,227 & 1,954 & .88 \\
\hline 10 & 192 & 66 & .34 \\
\hline 11 & 681 & 1,058 & 1.55 \\
\hline 12 & 240 & 90 & .37 \\
\hline 13 & 95 & 46 & .48 \\
\hline 14 & 587 & 122 & .21 \\
\hline 20 & 3,845 & 28 & .01 \\
\hline 21 & 4,119 & 43 & .01 \\
\hline 29 & 1,340 & 90 & .07 \\
\hline Total (rounded) & 17,200 & 6,600 & 一 \\
\hline
\end{tabular}

Irrigation also occurs with municipal water in Cedar City and Enoch. Recharge from irrigation with municipal water was assumed to be 15 percent of the extra water applied during the summer as described in the "Recharge" section of this report. Fifteen percent of the extra water applied is about equal to 8 percent of the annual municipal use, and the annual recharge during 1950-2000 was assumed to be 8 percent of the municipal use of wells. This analysis assumes that with increasing municipal ground-water withdrawals, recharge from the use of municipal springs for irrigation is insignificant. Municipal recharge is assumed to be negligible for 193849 but increases with development. Recharge is about 700 acre-ft for 2000.

\section{Consumptive-Use Method}

During transient calibration, the inability to adequately simulate water-level fluctuations indicated that simulated recharge must vary more than determined by the percent-recharge method. A new method was developed to test the theory that during years with less-than- normal flow in Coal Creek, a higher percentage of the applied water is used to satisfy crop demand and a lower percentage becomes ground-water recharge. Conversely, during years with greater-than-normal flow in Coal Creek, a lower percentage of the applied water is used to satisfy crop demand, and a higher percentage becomes ground-water recharge. With the consumptive-use method, recharge from Coal Creek seepage, irrigation with surface water, and irrigation with ground water varied more than with the percent-recharge method (table 11).

Surface water applied to each area was determined by using the same methods described in the "Percentrecharge method" section of this report, but the percentage that becomes recharge was not assumed. Instead, it was assumed that 20 percent of the applied water becomes runoff or evaporates from the fields, plants, or ditches. Utah State University (1994, p. 121) reports that runoff and evaporative losses range from 5 to 55 percent throughout Utah. The remaining 80 percent of the applied surface water reaches the root zone of the plants and either satisfies consumptive use of the plants or becomes ground-water recharge.

Because some areas of the valley are irrigated with both surface and ground water, it is not possible to determine what percentage of recharge each contributes. Eighty percent of ground water applied as irrigation is also considered to reach the root zone of the plants. The ground water applied to each of 31 areas was determined as described in the "Percent-recharge method" section of this report.

In addition to irrigation water, precipitation contributes to crop consumptive use. Utah State University (1994, p. 114) assumes that 80 percent of the precipitation during the growing season and 67 percent of the precipitation during the nongrowing season reaches the root zone. With these assumptions and the normal monthly distribution of precipitation at Cedar City, about 75 percent of the annual precipitation is estimated to reach the root zone.

Consumptive use in the study area is presented in table 12 as determined from digital land-use data compiled in 1989 (Utah Department of Natural Resources, Division of Water Resources, 1993) and consumptive use for each crop type (Utah State University, 1994, table $25)$. The total consumptive use for crops is about 49,200 acre-ft/yr, with an average consumptive use of about 2.47 $\mathrm{ft} / \mathrm{yr}$. Because the surface-water and ground-water irrigation areas contain enclosed nonirrigated and noncrop areas, the total nonresidential part of the delineated irrigation areas is about 32,600 acres. This is more than the 
Table 11. Conceptual annual recharge from irrigation for selected years determined by different methods of calculation, Cedar Valley, Iron County, Utah

[Amounts in acre-feet]

\begin{tabular}{|c|c|c|c|c|c|}
\hline \multirow[b]{2}{*}{ Year } & \multicolumn{4}{|c|}{ Percent-Recharge Method } & \multirow{2}{*}{$\begin{array}{c}\begin{array}{c}\text { Consumptive-Use } \\
\text { Method }\end{array} \\
\text { Total recharge from } \\
\text { irrigation and Coal Creek }\end{array}$} \\
\hline & $\begin{array}{l}\text { Recharge from } \\
\text { irrigation with } \\
\text { surface water }\end{array}$ & $\begin{array}{l}\text { Recharge from } \\
\text { irrigation with } \\
\text { ground water }\end{array}$ & $\begin{array}{l}\text { Recharge from } \\
\text { seepage from Coal } \\
\text { Creek }\end{array}$ & $\begin{array}{l}\text { Total recharge from } \\
\text { irrigation and Coal } \\
\text { Creek }\end{array}$ & \\
\hline $1938-49$ & 12,800 & 6,600 & 2,400 & 21,800 & 22,100 \\
\hline 1959 & 5,500 & 8,900 & 1,000 & 15,400 & 8,500 \\
\hline 1977 & 3,400 & 11,500 & 800 & 15,700 & 15,200 \\
\hline 1983 & 29,900 & 6,100 & 6,400 & 42,400 & 57,300 \\
\hline 2000 & 7,700 & 9,000 & 1,700 & 18,400 & 23,200 \\
\hline
\end{tabular}

crop area of 19,900 acres (table 12). Because the amount of applied water is calculated as being distributed over the larger area, the amount of consumptive use must also be calculated as distributed over the large area. On the basis of types of crops and amount of nonirrigated land in each area, the distributed consumptive use is $1.07 \mathrm{ft} / \mathrm{yr}$ on about 3,800 acres and $1.54 \mathrm{ft} / \mathrm{yr}$ on about 28,800 acres; the total distributed consumptive use on nonresidential areas is about 48,400 acre-ft/yr.

Recharge in each irrigation area for each year was calculated with the equation:

$$
\begin{aligned}
& \text { Recharge }=\text { Pfactor } x \text { effprec }+0.8 \times \text { (applied surface } \\
& \text { water }+ \text { applied ground water) }- \text { consumptive use (9) }
\end{aligned}
$$

where:

Recharge $=$ recharge rate, $\mathrm{in} \mathrm{ft} / \mathrm{yr}$;

Pfactor $=$ multiplier to vary precipitation for each year, annual precipitation/average annual precipitation;

effprec $=0.75 \mathrm{x}$ average annual precipitation; and applied surface water, applied ground water and consumptive use are all defined in $\mathrm{ft} / \mathrm{yr}$.

Simulated recharge from irrigation with surface water in the Cedar City area and from municipal water in Cedar City and Enoch was assumed to be the same percentage as in the "Percent-recharge method" section of this report. It is difficult to determine consumptive-use requirements and amount applied in urban and residential areas, and the above equation was not used in those areas.
Table 12. Land use and consumptive use of water by crops, Cedar Valley, Iron County, Utah, 1989

\begin{tabular}{|c|c|c|c|}
\hline \multirow[b]{2}{*}{ Land-use description } & \multirow[b]{2}{*}{$\begin{array}{c}\text { Area } \\
\text { (acres) }\end{array}$} & \multicolumn{2}{|c|}{ Consumptive use } \\
\hline & & $\begin{array}{l}\text { (feet per } \\
\text { year) }\end{array}$ & $\begin{array}{l}\text { (acre-feet } \\
\text { per year, } \\
\text { rounded) }\end{array}$ \\
\hline \multicolumn{4}{|c|}{ Crop } \\
\hline Pasture / grass hay & 8,931 & 2.32 & 20,700 \\
\hline Alfalfa & 8,314 & 2.86 & 23,800 \\
\hline Grain & 2,377 & 1.79 & 4,300 \\
\hline Corn & 178 & 1.58 & 280 \\
\hline Grass / turf & 46 & 2.10 & 100 \\
\hline Fruit / garden & 11 & 1.44 & 20 \\
\hline Subtotal (rounded) & 19,900 & & 49,200 \\
\hline \multicolumn{4}{|c|}{ Urban and Residential } \\
\hline Residential & 6,450 & & \\
\hline Farmsteads & 1,048 & & \\
\hline $\begin{array}{l}\text { Commercial / industrial / } \\
\text { transportation }\end{array}$ & 962 & & \\
\hline \multirow[t]{2}{*}{ Subtotal (rounded) } & 8,500 & & \\
\hline & Open & & \\
\hline Riparian / wetlands & 4,757 & & \\
\hline Idle / fallow / open & 4,353 & & \\
\hline Open water & 66 & & \\
\hline Subtotal (rounded) & 9,200 & & \\
\hline Total (rounded) & $\mathbf{3 7 , 5 0 0}$ & & \\
\hline
\end{tabular}

[Consumptive use: Utah State University, 1994, table 25] 


\section{Model Construction}

Construction of the ground-water flow model was accomplished by discretization of the hydrologic properties of the ground-water system; establishment of model boundaries that represent conceptual hydrologic boundaries; determination of recharge rates and ground-water withdrawal rates for the steady-state simulation and each stress period of the transient simulation; and assignment of model parameters to recharge, discharge, and hydrologic properties.

Given the amount and complexity of the input data, it is impractical to present or reference all required information to reconstruct the model from the information presented in this report. A copy of the model and associated data sets can be obtained from the USGS Utah Water Science Center, Salt Lake City, Utah.

The model described in this report uses parameters (Harbaugh and others, 2000, p. 4) to define much of the input data. A parameter is a single value that is given a name and determines the value of a variable in the finitedifference ground-water flow equation at one or more model cells. When parameters are used, the data value for a cell is calculated as the product of the parameter value, which might apply to many cells, and a cell multiplier, which applies only to that cell (Harbaugh and others, 2000, p. 13). Sensitivity analysis (Hill and others, 2000, p. 98) was used to guide model construction and calibration.

\section{Spatial Discretization}

Areally, the model is discretized into a grid of rectangular cells; each cell has homogeneous properties. The boundary of active cells (fig. 24) delineates the lateral boundaries of the simulated ground-water system and generally corresponds with the lateral extent of the unconsolidated basin fill in Cedar Valley. The rectangular model grid contains 91 rows and 34 columns; cell size is variable and active cells range in size from about 55 to 250 acres. Areas of small cell size generally represent areas where more data are available. Rows 1 to 7 are included in the model grid to simulate the northern extent of the basin fill. During simulations, however, these cells become unsaturated, causing numerical instability. Because no data are available to determine whether the basin fill in the area is saturated, the cells were made inactive. The model grid is rotated clockwise about 23 degrees from north so that cell faces are generally parallel to the boundary of the unconsolidated basin fill. The ground-water flow equations are formulated at the center of each model cell. Flow area and gradient used to determine flow through the cell are determined at the center of the cell and represent the average area and gradient through the cell.

Vertically, the model is composed of three layers representing units $\mathrm{A}$ and $\mathrm{B}$ of the unconsolidated basin fill as described by Hurlow (2002, p. 13); the maximum total simulated thickness of 3,000 ft occurs near Rush Lake (fig. 24). As explained in the "Hydrogeology" section of this report, units A and B are assumed to have similar permeability; therefore, model layer definition is not dependent upon the horizontal or vertical extent of the individual units. Vertical discretization was used in the model to enable simulation of known vertical hydraulic gradients. The top model layer (layer 1) was assigned a saturated thickness of about $50 \mathrm{ft}$ to represent unconfined conditions at the top of the ground-water system throughout the valley. The water-level altitude used to determine the top of the saturated basin fill was based on observed water levels in March 1939 and the ending water levels of the steady-state simulation. The altitude of the bottom of layer 1 was set about $50 \mathrm{ft}$ below saturated altitude. Altitude of the bottom of layer 3 was determined by subtracting the combined thickness of the units A and B (Hurlow, 2002, fig. 10) from land-surface altitude. The thickness between the bottom of layer 1 and the bottom of layer 3 was evenly divided into layers 2 and 3 . The thicknesses of layers 2 and 3 range from about 20 to $1,470 \mathrm{ft}$.

All model layers were assigned as convertible layers in MODFLOW-2000. This allows layers to be confined if the simulated water level is above the top of the layer and unconfined if the simulated water level is below the top of the layer. Observed water levels during the period represented by the transient simulation decline more than $50 \mathrm{ft}$ in some areas; accurately simulating those declines will cause layer 2 to become unconfined near some pumping wells during the transient simulation. MODFLOW-2000 requires the top layer also be assigned as a convertible layer, and the model automatically changes to confined conditions if the layer becomes fully saturated. To prevent the model from simulating unrealistic confined conditions, the top of the model layer was assigned an artificially high altitude of 7,000 ft at all locations instead of land-surface altitude. 


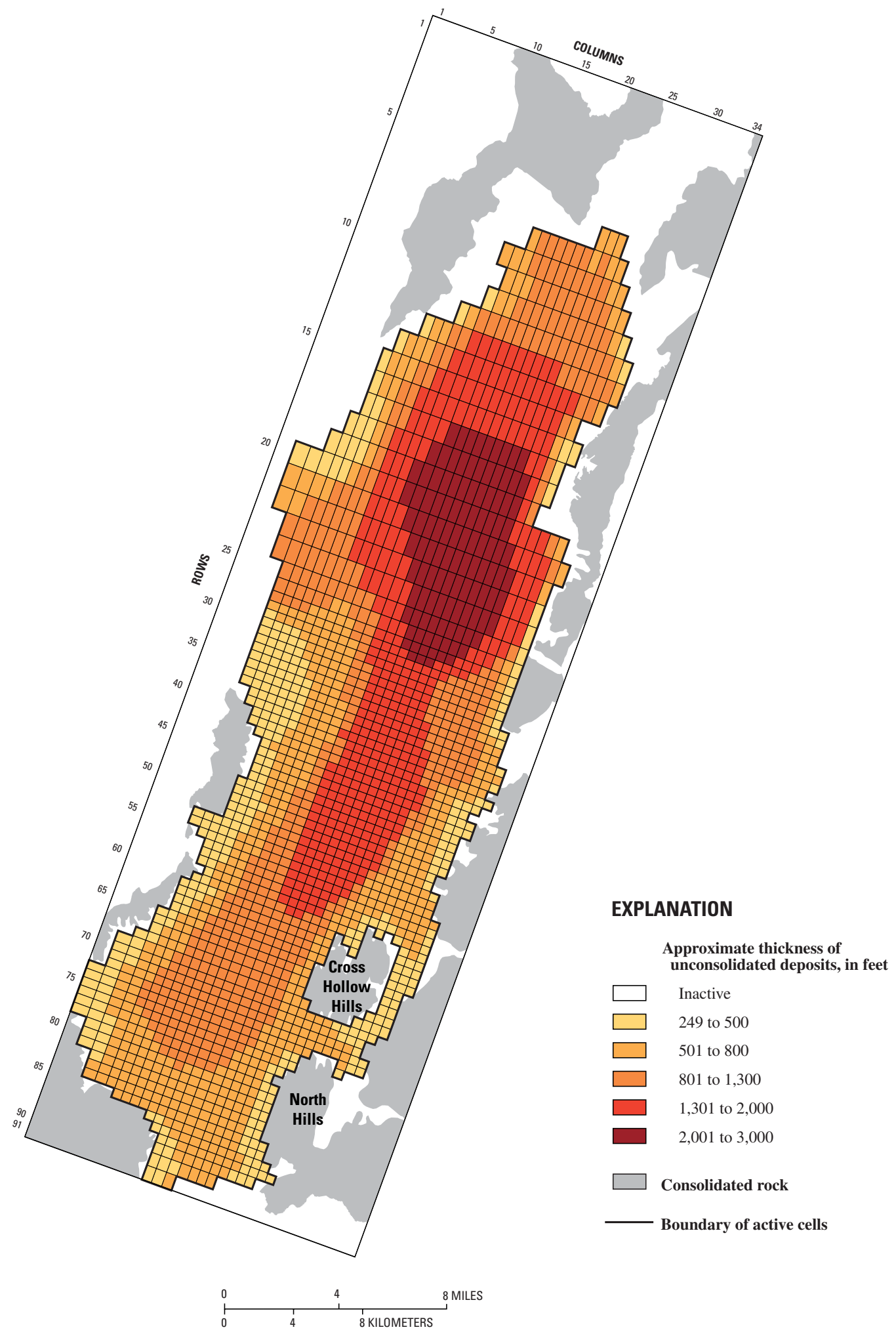

Figure 24. Model grid and approximate simulated thickness of the unconsolidated basin fill in the ground-water flow model, Cedar Valley, Iron County, Utah. 


\section{Temporal Discretization}

The steady-state model simulates conditions in the late 1930s and the 1940s. Ground-water withdrawals were occurring, but were much less than in later years. Water-level observations indicate that ground-water levels were similar in March 1939 and March 1950 (figs. 8 and 10). Water levels fluctuate between those dates, but overall, the ground-water system appears to have equilibrated discharge with recharge during those years. Because of the similarity in water levels, water-level observations from both March 1939 and March 1950 were used to calibrate the steady-state simulation. If levels were available for both years, the 1950 level was used.

The transient model simulates 63 yearly stress periods from 1938 to 2000. The flow in Coal Creek and ground-water withdrawals were calculated from March 1 to February 28 for each year, and the simulated water levels are compared to the observed water levels for the next year. For example, March 2001 water levels are compared to the simulated water levels at the end of stress period 63, which simulates recharge and discharge from March 1, 2000, to February 28, 2001. Simulated water levels from the steady-state simulation were used as starting water levels in the transient simulation, and the first 12 periods in the transient simulation are steadystate periods to represent the steady-state conditions during 1938-49. The transient model was constructed to simulate annual and longer-term water-level fluctuations. Given the uncertainties in local ground-water recharge and pumping withdrawals, annual fluctuations at specific points should be considered approximations.

\section{Distribution of Aquifer Characteristics}

The three-layer model represents saturated, unconsolidated basin fill. The top model layer simulates the unconfined conditions that typically exist near the top of the saturated zone. Layers 2 and 3 simulate confined conditions that typically exist deeper in the saturated basin fill. Although continuous clay layers are not evident in Cedar Valley, lenses of fine-grained material confine water in the deeper basin fill (see "Unconsolidated basin fill" section of this report). The hydraulic characteristics that control simulated water levels are horizontal hydraulic conductivity, horizontal-to-vertical anisotropy of hydraulic conductivity, specific yield in model layer 1, and specific storage in model layers 2 and 3. The model was constructed to allow aquifer characteristics to vary spatially by using parameters and multiplier and zone arrays (Harbaugh and others, 2000, p. 15).

\section{Hydraulic Conductivity and Horizontal-to-Vertical Anisotropy}

Hydraulic conductivity was assumed to decrease as the percentage of coarse material in the unconsolidated basin fill decreases (see the "Aquifer properties" section of this report). This variation was assigned with a multiplier array as shown in figure 25. The MODFLOW-2000 parameters for hydraulic conductivity (hk3, hkmid, hk4, hkedge, and hk5 on fig. 26) are multiplied by the "coarse" multiplier array to determine the hydraulic conductivity simulated at each cell in ft/d (fig. 27). The value of the parameter, however, is not the estimated hydraulic conductivity of the coarse material. It represents a combination of the conductivities of the coarse and fine materials. All model layers were assumed to have the same distribution of hydraulic conductivity.

Water-level measurements in some wells indicate probable vertical-head gradients within the unconsolidated basin fill. To simulate the measured vertical-head gradients, it is necessary for vertical hydraulic conductivity to be less than horizontal hydraulic conductivity in this model. This was simulated with parameters and a zone array defining the anisotropy of horizontal-to-vertical hydraulic conductivity (Harbaugh and others, 2000, p. 60 ). The parameters defining anisotropy (vaniconf, vaniuncon, and vani3) are the actual values of simulated anisotropy; no multiplier array is used.

\section{Specific Yield and Specific Storage}

Values of specific yield for layer 1 and specific storage for layers 2 and 3 were assumed to be smaller in the center of the valley where more fine-grained material is present than along the valley margins. Model layers 2 and 3 were assigned the same areal distribution of specific storage, and model layer 1 was assigned a similar distribution of specific yield. Specific storage is storage coefficient divided by the thickness of the confined layer. Bjorkland and others (1978, table 4) reported values of storage coefficient ranging from 0.0005 to 0.013 . For layer thickness ranging from about 20 to $1,500 \mathrm{ft}$ in layers 2 and 3, an equivalent range in specific storage is $6.5 \times 10^{-4} / \mathrm{ft}$ to $3 \times 10^{-7} / \mathrm{ft}$. The parameters defining specific yield and specific storage (syc, syf, ssc, and ssf) are the actual simulated values; no multiplier array is used. Because model layers 2 and 3 are simulated as convertible layers, layer 2 becomes unconfined at some locations during the transient simulation and the flow equations 


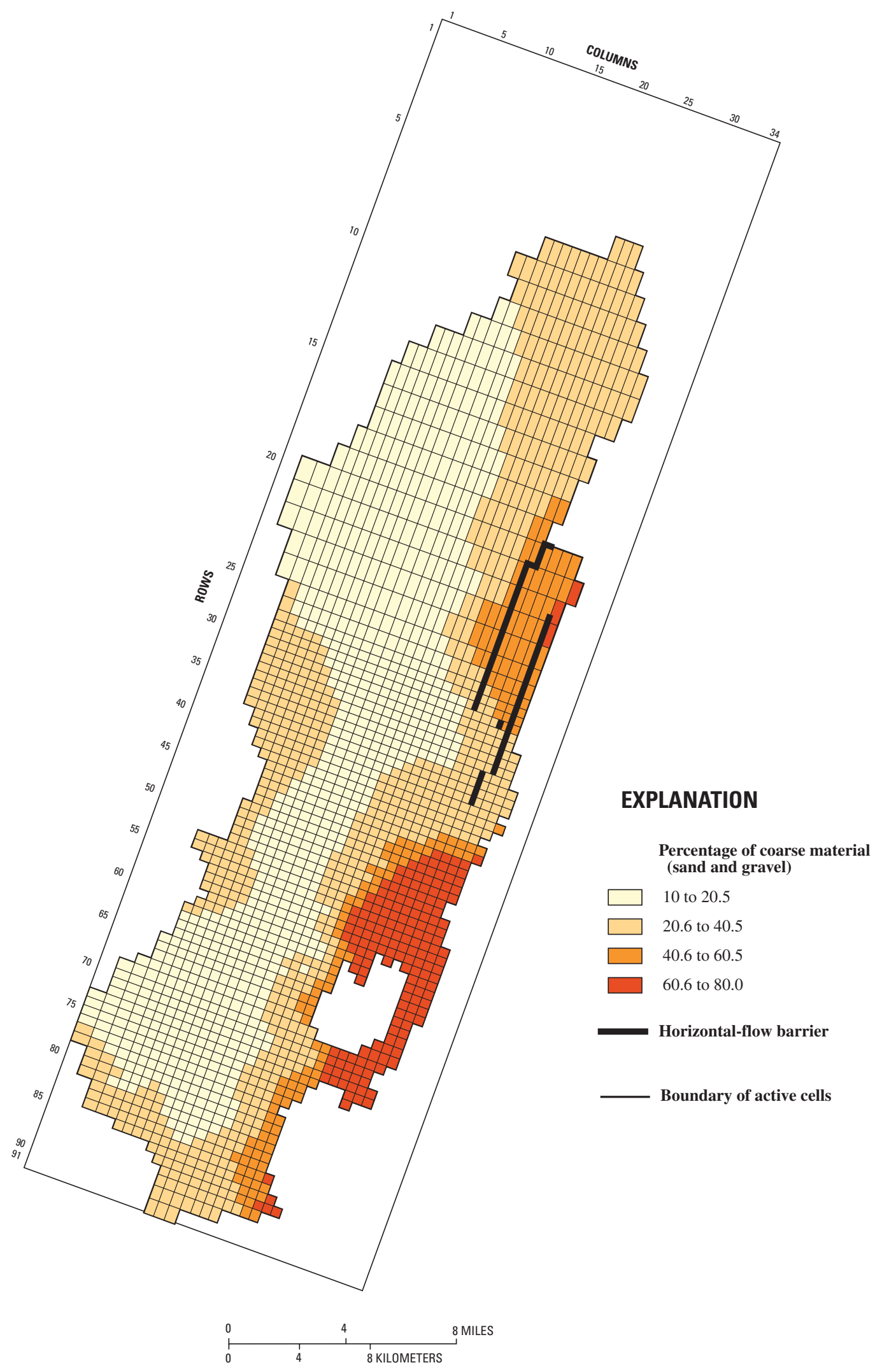

Figure 25. Horizontal-flow barriers and percentage of coarse material used as a multiplier array for hydraulic conductivity simulated in the ground-water flow model, Cedar Valley, Iron County, Utah. 


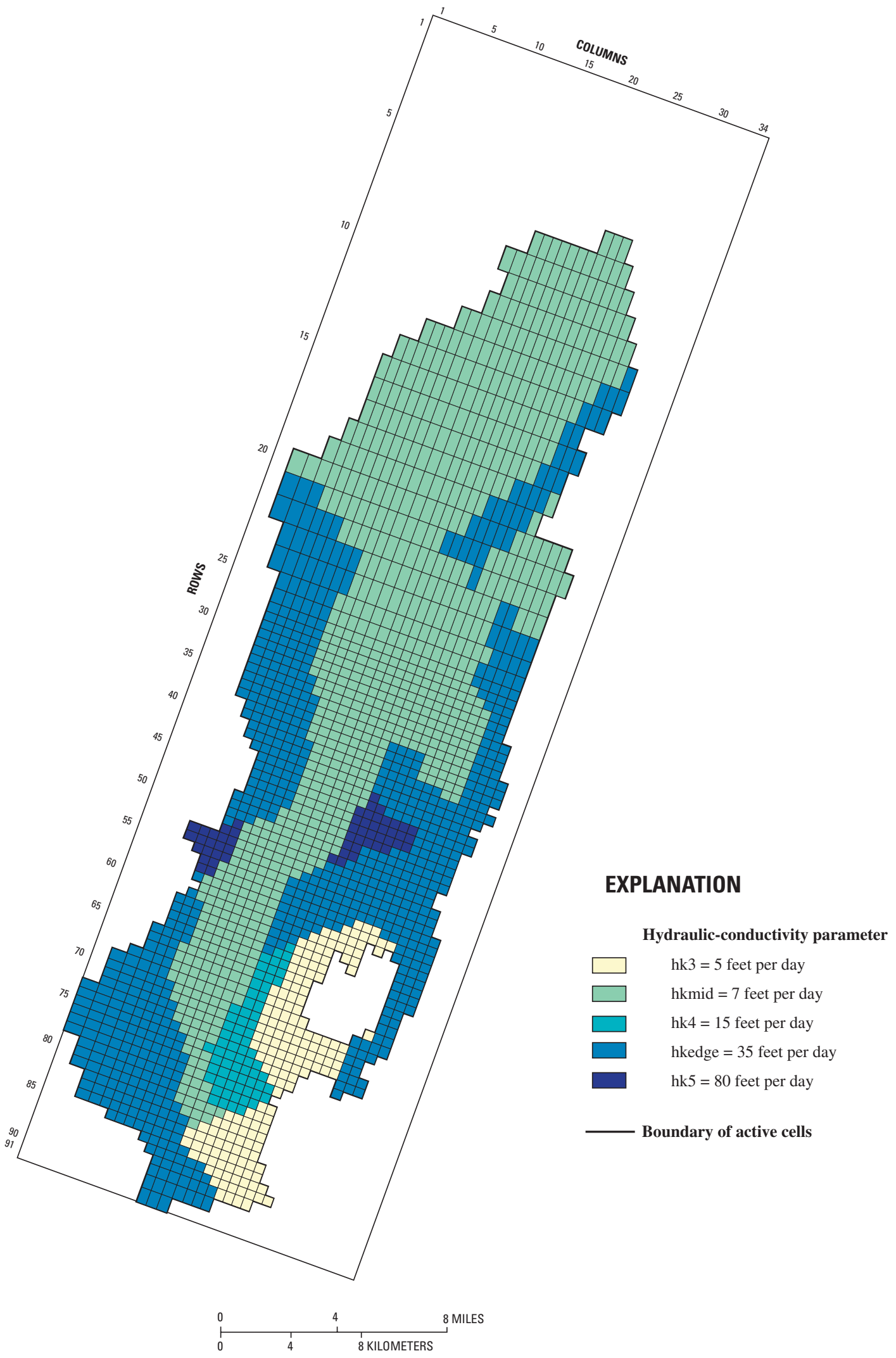

Figure 26. Parameters for hydraulic conductivity simulated in the ground-water flow model, Cedar Valley, Iron County, Utah. 


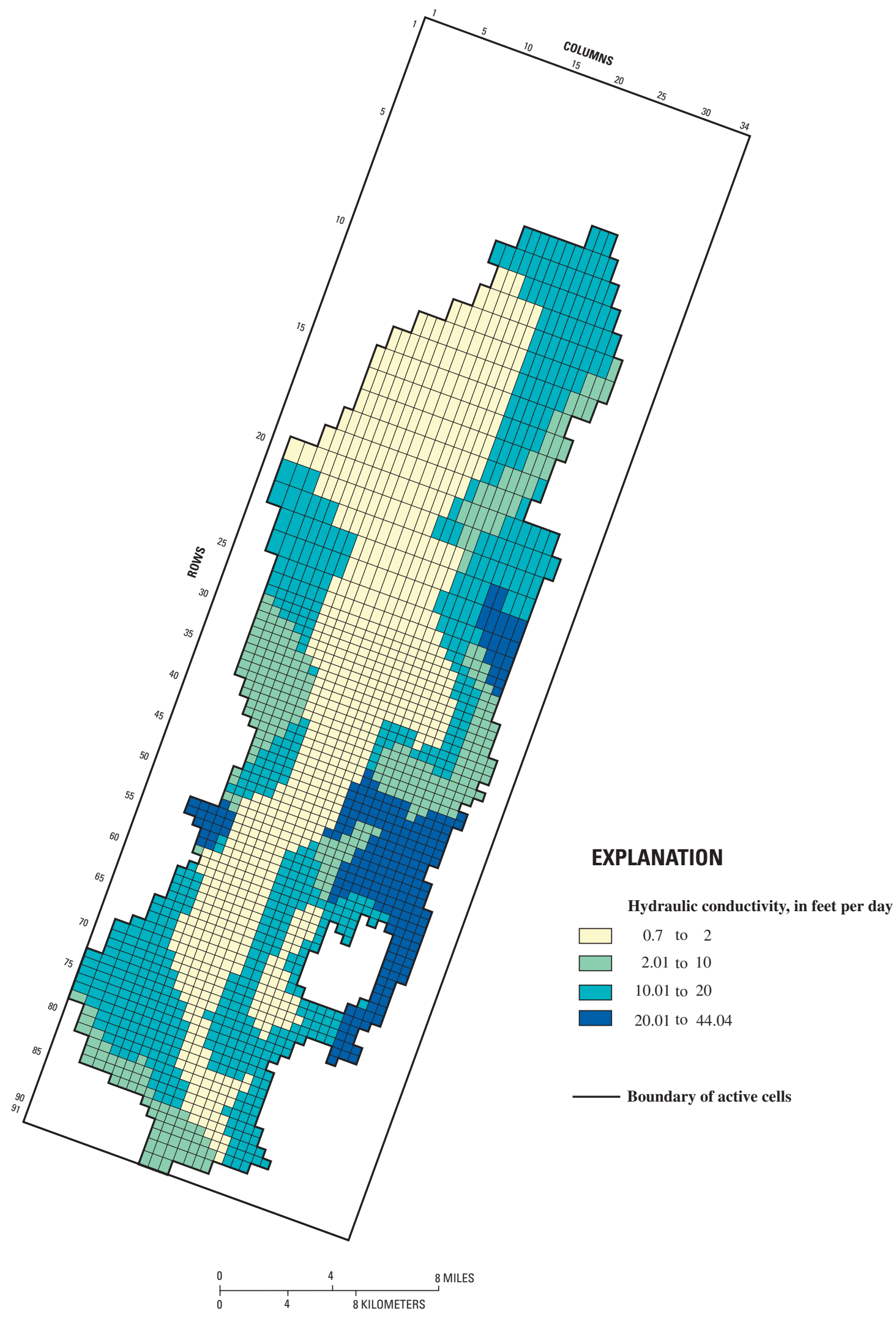

Figure 27. Distribution of hydraulic conductivity simulated in the ground-water flow model, Cedar Valley, Iron County, Utah. 
use specific yield instead of specific storage for those time steps or stress periods. The distribution of specific yield in layer 2 is the same as in layer 1 .

\section{Horizontal-Flow Barriers}

Observed water levels near and north of Enoch and discharge from the springs near Enoch could not be simulated by changes in hydraulic conductivity of model cells. Flow barriers were simulated with the Horizontal-Flow Barrier Package (Harbaugh and others, 2000, p. 63) to inhibit water moving from east to west in this area (fig. $25)$. The barrier is simulated near the eastern basinbounding fault system shown by Hurlow (2002, pl. 1). It is not known if the fault or some other undefined geology impedes ground-water flow in this area. This package allows hydraulic conductivity and flow between cells to be decreased without affecting the hydraulic conductivity of the adjacent cells. MODFLOW-2000 allows the value of conductance across the barrier to be defined as a parameter. For this simulation, the factor listed in the input file for the Horizontal-Flow Barrier Package is the inverse of the thickness of the barrier. The parameter (hfb) is hydraulic conductivity, in $\mathrm{ft} / \mathrm{d}$, which when multiplied by the factor gives the hydraulic characteristic required by MODFLOW-2000.

\section{Boundary Conditions}

The boundaries chosen for the model describe mathematically how the simulated ground-water system interacts with the surrounding hydrologic system. Mathematical boundaries used to represent hydrologic boundaries include no-flow boundaries, specified-flux boundaries, and head-dependent flux boundaries. These boundaries define the physical limits of the model and simulate recharge to and discharge from the groundwater system. No-flow boundaries are considered impermeable and no flow is simulated across them. Specifiedflux boundaries allow a specified rate of water through the cell and are used to simulate most recharge and some discharge in this model. Head-dependent flux boundaries simulate flow across the boundary proportional to the difference in heads across the boundary and are used to simulate some recharge and discharge in this model.

\section{No-Flow Boundaries}

Contacts between unconsolidated basin fill and consolidated rock around the basin fill are simulated as no-flow boundaries. At most locations around the valley, however, estimated inflow from consolidated rock is simulated as wells in cells near the boundary. The unconsoli- dated basin fill below the simulated basin fill also is considered a no-flow boundary. The higher seismic-wave velocity of unit $C$ (Hurlow, 2002, p. 9) indicates that it is not as permeable as units A and B. The Moenkopi Formation composing the Cross Hollow Hills and North Hills (fig. 24) also are considered to be no-flow boundaries. Hurlow (2002, fig. 23) reported low permeability for the sedimentary rocks of that formation. In a few areas along the margins of the valley, the saturated thickness of the unconsolidated basin fill is estimated to be less than $50 \mathrm{ft}$. The cells representing those areas are assigned as inactive to prevent numerical instability.

\section{Recharge Boundaries}

Recharge is simulated from irrigation, precipitation, seepage from Coal Creek, and inflow from consolidated rock and Parowan Valley. During transient simulation, recharge from south of the model area through unconsolidated basin fill is also simulated (see "Recharge" section of this report). Specified-flux and head-dependent flux boundaries are used to simulate all recharge. Recharge simulated by specified-flux boundaries does not change as simulated water levels change. Recharge simulated by head-dependent flux boundaries can change as a function of simulated water levels.

Areal recharge from irrigation, precipitation, and seepage from Coal Creek is simulated as a specified-flux boundary with the Recharge Package (Harbaugh and others, 2000, p. 67) and is applied to the highest active cell. Annual recharge from irrigation and precipitation (including seepage from Coal Creek) in irrigated areas, in acre-ft, was determined as explained in the "Recharge from irrigation" section of this report and is entered in MODFLOW-2000 as a multiplier array (fig. 28).

Sixty multiplier arrays are used in the transient simulation to account for changes in recharge because of changes in the application of surface water and ground water. To minimize the number of multiplier arrays needed as MODFLOW data, the recharge rates from surface-water irrigation were delineated into 13 periods of similar recharge, and the recharge rates from groundwater irrigation were divided into 24 periods of similar recharge. Each model stress period was assigned 1 of the 13 surface-water recharge periods and 1 of the 24 ground-water recharge periods. This aggregation introduces no more error than the estimate errors in applied water and percent recharge. General water-level trends dependent upon recharge rate are adequately simulated.

A recharge rate of $0.035 \mathrm{ft} / \mathrm{yr}$ from precipitation was assigned in all areas to achieve a recharge from precipitation of 5,900 acre-ft/yr (see "Recharge" section of 


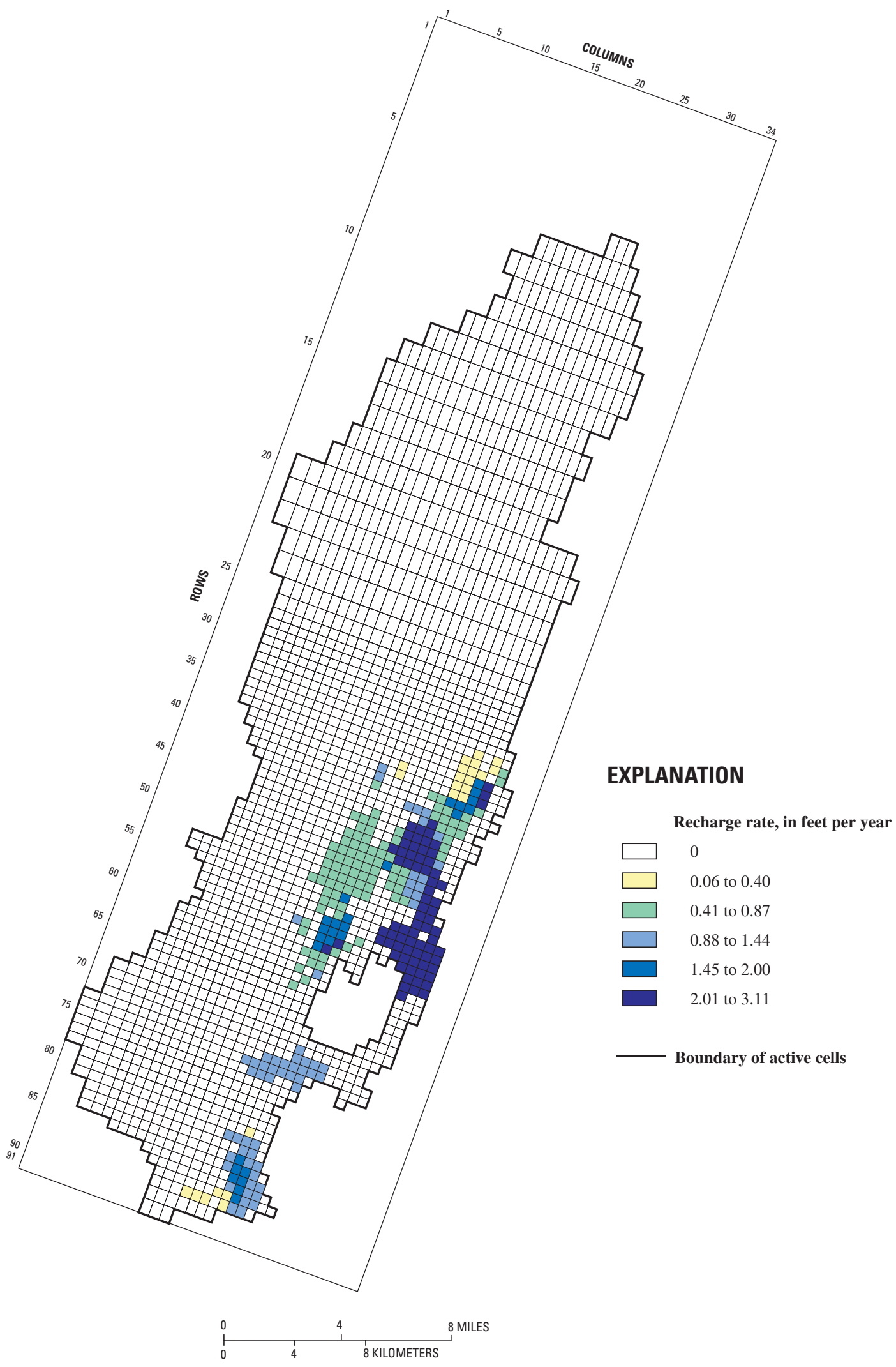

Figure 28. Distribution of recharge from irrigation simulated in the steady-state ground-water flow model, Cedar Valley, Iron County, Utah. 
this report) and is entered in MODFLOW-2000 as another multiplier array. This is less recharge from precipitation than in the conceptual budget (table 2) for a few reasons. First, a steady-state model must have a balanced budget. Using the conceptual recharge would have required simulating more discharge to evapotranspiration, springs, and outflow to other areas than estimated. Second, recharge in arid valleys estimated by using newer methods is typically less than recharge estimated by using the Maxey-Eakin method (Hevesi and others, 1998, p. 24). Third, recharge from precipitation and Coal Creek estimated by using the chloride mass-balance calculation presented in this report is less than recharge from precipitation calculated using the Maxey-Eakin method. Because this rate is small, it is considered an insignificant part of the budget on irrigated lands. This value was not changed during the transient simulation.

The MODFLOW-2000 Recharge Package allows the value of recharge flux to be defined as one or more parameters (Harbaugh and others, 2000, p. 68). In this model, the multiplier arrays define the conceptual recharge rate at each cell in $\mathrm{ft} / \mathrm{yr}$ and the recharge parameters multiply the conceptual recharge by a constant value and convert the rate to $\mathrm{ft} / \mathrm{d}$. Six recharge parameters were defined for recharge from irrigation and precipitation (coalirr1, coalirr2, coalseep, shirts, wellirr, and precip). Each recharge parameter was initially set equal to 0.00274 to simulate conceptual recharge, but changed during calibration (fig. 29).

Inflow from consolidated rock and Parowan Valley is simulated as specified-flux boundaries with the Well Package (Harbaugh and others, 2000, p. 69) in active cells in layers 2 and 3 near the no-flow boundaries (fig. 30). The rate of inflow from each area was assigned to be equally divided between layers 2 and 3 , in $\mathrm{ft}^{3} / \mathrm{d}$. MODFLOW-2000 allows the value of the volumetric recharge rate to be defined as one or more parameters (Harbaugh and others, 2000, p. 70). Six MODFLOW-2000 parameters were defined for recharge from bedrock and inflow from Parowan Valley (bedrockno, bedrockwes, bedrocksw, bedrockse, bedrockeas, and parowan). Separate parameters were used so that sensitivity to each area of inflow could be evaluated and inflow could be easily varied during calibration. Each well parameter was initially set equal to 1 to simulate conceptual recharge.

For the steady-state simulation, inflow from consolidated rock was assumed to equal the inflow determined for the 1961-90 average annual precipitation. For the transient simulation, the inflow from consolidated rock varies with annual precipitation. On the basis of the regression equation (eq. 2) to determine subsurface inflow from consolidated rock, the recharge does not vary linearly with a change in precipitation. The yearly recharge multiplier was calculated with the following equation:

$$
\text { Qmult }=10^{(1.10 \times \log (\text { Pmult }))}
$$

where:

Qmult = multiplier to vary inflow for each year, and

Pmult = annual precipitation divided by average annual precipitation at Cedar City Airport, 1951-2000.

Annual precipitation data are not available before 1951 , and the 1950 annual precipitation is assumed to equal the 1961-90 average annual precipitation. Annual precipitation, precipitation multiplier, and inflow multiplier are listed in table 13.

Another method of simulating inflow would have been to use general head boundaries, which allow flow across the boundary to vary as the water-level difference across the boundary changes. In this study area, the amount of inflow from consolidated rock to basin fill is considered to be dependent upon climate, geography, and vegetation of the consolidated rock areas. Lowering the water levels in the valley will not induce additional longterm recharge because more water is not available. Inflow from Parowan Valley may be more dependent upon the water-level difference across the boundary than is inflow from consolidated rock, but the flow from Parowan Valley also is limited. It also is likely that water-level changes in Cedar Valley caused by climate or groundwater development would also occur in Parowan Valley, thereby minimizing the change in water-level difference between the two valleys.

Recharge through unconsolidated basin fill from south of the model area during the transient simulation was simulated in all model layers with the General-Head Boundary (GHB) package (Harbaugh and others, 2000, p. 76). Because this boundary is a discharge boundary in the steady-state simulation, more detail is provided in the "Discharge boundaries" section of this report. 


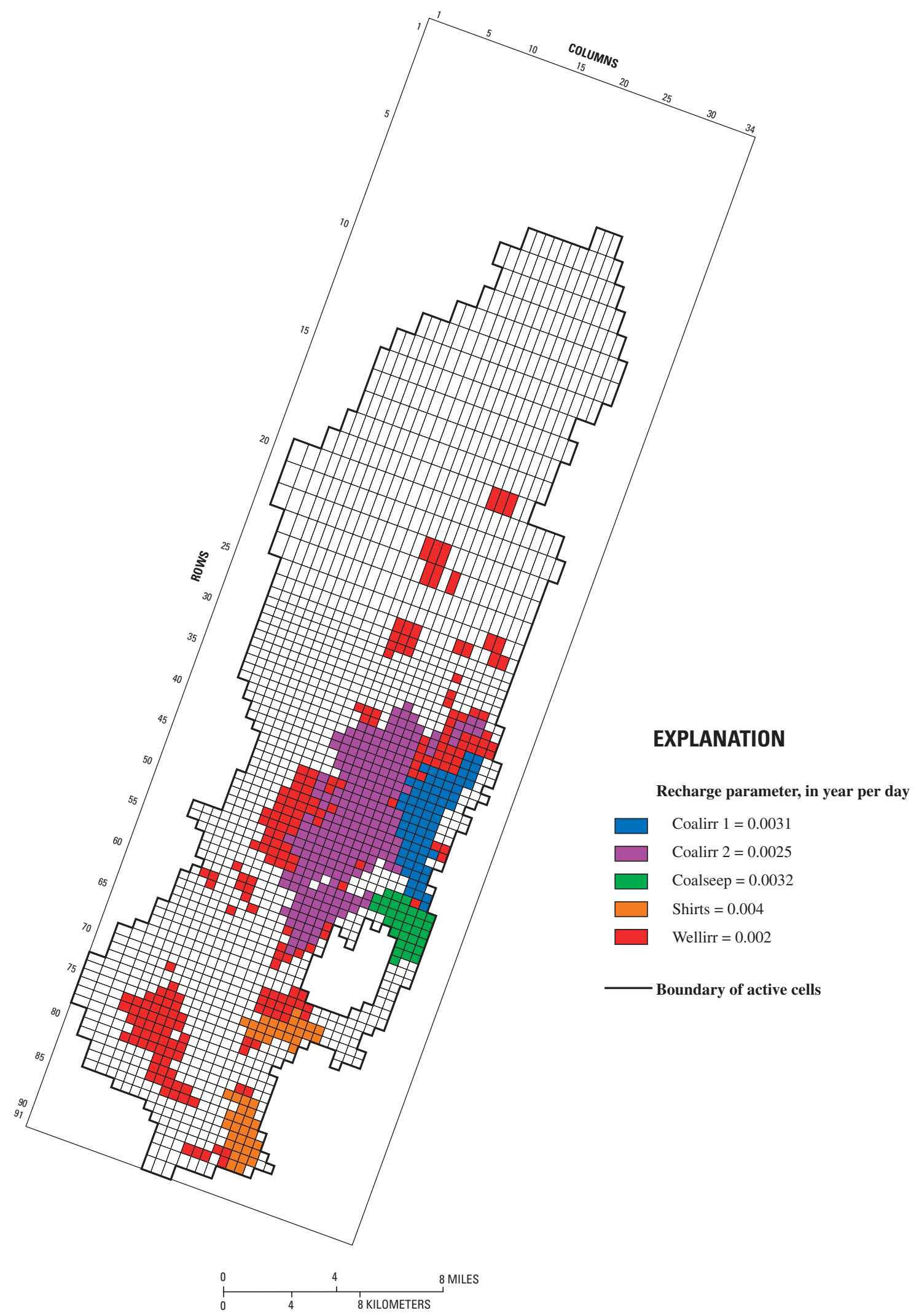

Figure 29. Parameters for recharge from irrigation simulated in the steady-state ground-water flow model, Cedar Valley, Iron County, Utah. 


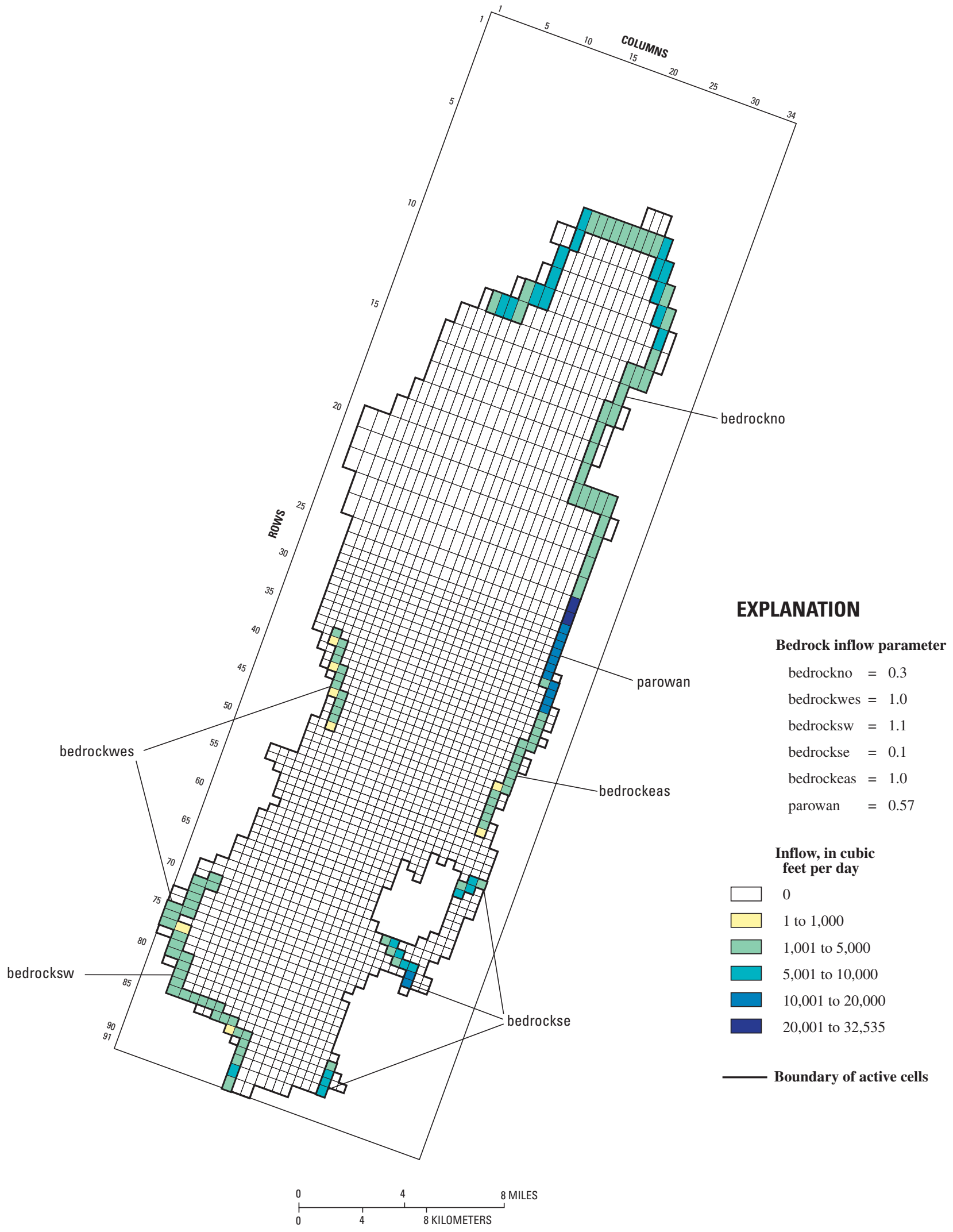

Figure 30. Distribution of inflow from consolidated rock and Parowan Valley simulated in the steady-state ground-water flow model, Cedar Valley, Iron County, Utah. 
Table 13. Annual precipitation, precipitation multiplier, and inflow multiplier used to calculate annual variation of inflow from consolidated rock in the transient ground-water flow model, Cedar Valley, Iron County, Utah

[Annual precipitation at Cedar City airport (National Oceanic and Atmospheric Administration, 1951-2000); Precipitation multiplier equals annual precipitation divided by the 1951-2000 average of 10.8 inches; Inflow multiplier = $10^{(1.10 \times \log (\text { Pmult }))}$, where Pmult $=$ Precipitation multiplier $]$

\begin{tabular}{|c|c|c|c|}
\hline Year & $\begin{array}{c}\text { Annual precipitation } \\
\text { at Cedar City airport } \\
\text { (inches) }\end{array}$ & $\begin{array}{l}\text { Precipitation } \\
\text { multiplier } \\
\text { (Pmult) }\end{array}$ & $\begin{array}{c}\text { Inflow } \\
\text { multiplier } \\
\text { (Omult) }\end{array}$ \\
\hline 1951 & 8.92 & 0.83 & 0.81 \\
\hline 1952 & 8.67 & .80 & .79 \\
\hline 1953 & 9.33 & .86 & .85 \\
\hline 1954 & 9.03 & .84 & .82 \\
\hline 1955 & 8.33 & .77 & .75 \\
\hline 1956 & 6.33 & .59 & .56 \\
\hline 1957 & 12.97 & 1.20 & 1.22 \\
\hline 1958 & 8.01 & .74 & .72 \\
\hline 1959 & 5.2 & .48 & .45 \\
\hline 1960 & 8.48 & .79 & .77 \\
\hline 1961 & 12.41 & 1.15 & 1.17 \\
\hline 1962 & 9.19 & .85 & .84 \\
\hline 1963 & 11.53 & 1.07 & 1.07 \\
\hline 1964 & 7.88 & .73 & .71 \\
\hline 1965 & 15.08 & 1.40 & 1.44 \\
\hline 1966 & 7.45 & .69 & .66 \\
\hline 1967 & 16.94 & 1.57 & 1.64 \\
\hline 1968 & 8.5 & .79 & .77 \\
\hline 1969 & 12.3 & 1.14 & 1.15 \\
\hline 1970 & 11.25 & 1.04 & 1.05 \\
\hline 1971 & 11.1 & 1.03 & 1.03 \\
\hline 1972 & 11.78 & 1.09 & 1.10 \\
\hline 1973 & 10.88 & 1.01 & 1.01 \\
\hline 1974 & 7.86 & .73 & .71 \\
\hline 1975 & 12.99 & 1.20 & 1.23 \\
\hline 1976 & 6.38 & .59 & .56 \\
\hline 1977 & 7.65 & .71 & .68 \\
\hline 1978 & 13.9 & 1.29 & 1.32 \\
\hline 1979 & 11.14 & 1.03 & 1.03 \\
\hline 1980 & 15.63 & 1.45 & 1.50 \\
\hline 1981 & 12.08 & 1.12 & 1.13 \\
\hline 1982 & 15.51 & 1.44 & 1.49 \\
\hline 1983 & 14.77 & 1.37 & 1.41 \\
\hline 1984 & 13.91 & 1.29 & 1.32 \\
\hline 1985 & 11.39 & 1.05 & 1.06 \\
\hline 1986 & 13.12 & 1.21 & 1.24 \\
\hline 1987 & 13.89 & 1.29 & 1.32 \\
\hline 1988 & 11.61 & 1.08 & 1.08 \\
\hline 1989 & 6.24 & .58 & .55 \\
\hline 1990 & 10.91 & 1.01 & 1.01 \\
\hline 1991 & 9.82 & .91 & .90 \\
\hline 1992 & 11.53 & 1.07 & 1.07 \\
\hline 1993 & 11.46 & 1.06 & 1.07 \\
\hline 1994 & 10.88 & 1.01 & 1.01 \\
\hline 1995 & 12.14 & 1.12 & 1.14 \\
\hline 1996 & 10.51 & .97 & .97 \\
\hline 1997 & 10.72 & .99 & .99 \\
\hline 1998 & 12.86 & 1.19 & 1.21 \\
\hline 1999 & 7.06 & .65 & .63 \\
\hline 2000 & 12.97 & 1.20 & 1.22 \\
\hline
\end{tabular}

Discharge Boundaries

Discharge is simulated to evapotranspiration; to wells; as outflow through unconsolidated basin fill in Mud Springs Canyon, Iron Springs Gap, and the south end of the valley during steady-state and some transient periods; and to springs near Enoch. Discharge to evapotranspiration, outflow through unconsolidated basin fill, and springs is head dependent. In the steady-state simulation, the sum of these discharge components is equal to the simulated recharge (most of which is specified-flux) minus well withdrawal.

Discharge to evapotranspiration is simulated in layer 1 with the Evapotranspiration Package (Harbaugh and others, 2000, p. 73). The rate of evapotranspiration simulated depends on the maximum evapotranspiration rate, the depth below land surface at which transpiration stops (extinction depth), and the simulated ground-water level (McDonald and Harbaugh, 1988, fig. 42). Data required for the Evapotranspiration Package are the altitude of the evapotranspiration surface, extinction depth, and the maximum evapotranspiration rate. The altitude of the evapotranspiration surface was estimated as land surface from USGS 1:24,000-scale topographic maps. In most areas of evapotranspiration, the error associated with the altitude estimate is 5 to $10 \mathrm{ft}$ because the contour interval is 10 or $20 \mathrm{ft}$. An extinction depth of $30 \mathrm{ft}$ was used initially for all areas of evapotranspiration. This was changed to $19 \mathrm{ft}$ during calibration to more closely match the areas where evapotranspiration is estimated to have occurred during 1938-49 (fig. 31). The maximum rate of evapotranspiration initially was assigned as $1 \mathrm{ft} / \mathrm{yr}$ in all areas of evapotranspiration with a multiplier array, but was changed during calibration. The MODFLOW-2000 Evapotranspiration Package allows the value of maximum evapotranspiration flux to be defined as a parameter (Harbaugh and others, 2000, p. 74). The evapotranspiration parameters (et1 and et2) used in this model multiply the maximum rate of evapotranspiration by a constant value and convert the rate from $\mathrm{ft} / \mathrm{yr}$ to $\mathrm{ft} / \mathrm{d}$. Input to the Evapotranspiration Package was not changed during the transient simulation, but the rate of evapotranspiration varies as simulated water levels vary.

Discharge to wells is simulated in all layers with the Well Package (Harbaugh and others, 2000, p. 69). The Well Package simulates a specified-flux boundary in each cell to which a well is assigned. Data required for the Well Package are the pumpage rate in each layer. The distribution of pumpage among layers in each well was determined prior to input into MODFLOW-2000. MODFLOW-2000 allows the value of the volumetric recharge rate (discharge is entered as a negative recharge rate) 


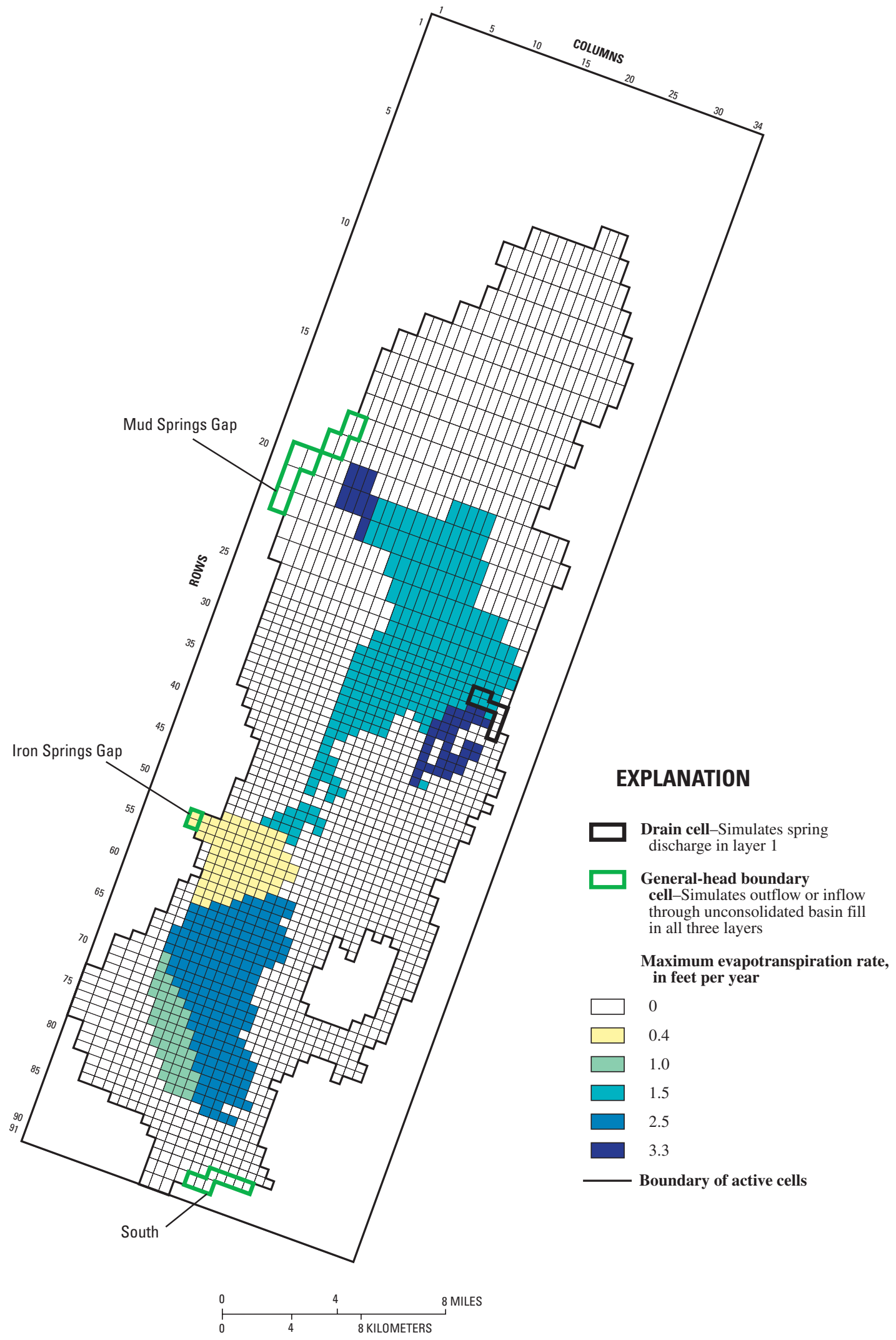

Figure 31. Distribution of evapotranspiration, springs, and general-head boundaries simulated in the ground-water flow model, Cedar Valley, Iron County, Utah. 
from wells to be defined as one or more parameters (Harbaugh and others, 2000, p. 70). One MODFLOW2000 parameter was defined initially for discharge to wells (parameter pump). During model development, however, it was noted that the definition of the rate of ground-water withdrawal as a model parameter caused many model parameters to have correlation coefficients of 1.0. This indicated that a unique model could not be determined if well discharge was a calibration parameter, and wells were assigned as a fixed withdrawal rate.

Ground-water withdrawal for individual wells is needed for the steady-state simulation and for each annual stress period in the transient simulation. Records for ground-water withdrawal are published for individual wells for 1938-40 (Thomas and Taylor, 1946, p. 130133), 1945-53 (Thomas and others, 1952, table 1; and Waite and others, 1954, table 7), and 1954-60 (Sandberg, 1962, table 3). No data are published for 1941-44. For 1961 to 2001, ground-water withdrawal for irrigation is published only as a total for the entire valley. For most of this period, estimates of total irrigation ground-water withdrawal were obtained from the Utah Department of Natural Resources, Division of Water Rights, as reported by the local water commissioner. No records are available for individual wells. During the period of this study, irrigation ground-water withdrawal was estimated for individual wells by field inventory. Cedar City municipal ground-water withdrawals during $1960-78$ for public supply were obtained from the Cedar City Engineers Office. Other withdrawals for public supply were estimated to be unsubstantial prior to 1979. For 1979 to 2001, ground-water withdrawals for public supply are published for individual wells by the Utah Department of Natural Resources, Division of Water Rights.

The steady-state withdrawal for each irrigation well was calculated as the average withdrawal reported for 1938-40 and 1945-49. No public-supply wells are simulated for the steady-state period. For the transient simulation, withdrawal reported for each well was used for 1950-60. Irrigation withdrawal for each well had to be estimated for 1961-2000 by projecting the withdrawal reported in 1960 (Sandberg, 1962, table 3) forward in time. The estimate for withdrawal at each well for each year was calculated by multiplying the withdrawal at a specified well for the previous year by the ratio of total irrigation withdrawal for the current year divided by the total for the previous year. When a new irrigation well was completed as a replacement to an adjacent older well or a well was completed in an area that was not previously irrigated, well withdrawal was estimated by projecting backward in time to the well-completion date using the same method described previously, but starting with the estimate of withdrawal made during this study. Withdrawals were not calculated for older wells replaced by newer wells unless the older well was known to be in use. Simulated ground-water withdrawals range from about 12,500 acre-ft in 1952 to about 39,700 acre-ft in 1974. Distribution of the 13,300 acre- $\mathrm{ft} / \mathrm{yr}$ simulated in the steady-state model (1938-49) is shown in figure 32. Distribution of the 33,900 acre-ft simulated in the transient model for 2000 is shown in figure 33.

The described method for estimating irrigation ground-water withdrawal from wells does not account for annual variations in each well that may result from surface-water availability or individual irrigation practices. If the estimated withdrawal is different from the actual withdrawal for a specific well for any year or number of years, annual simulated water levels may be different from annual measured water levels near the well. The overall simulated water-level trends throughout the valley, however, should be similar to observed trends.

Outflow through the unconsolidated basin fill in Mud Springs Canyon, Iron Springs Gap, and south near Kanarra (fig. 31) was simulated in all model layers with the GHB Package (Harbaugh and others, 2000, p. 76). The GHB Package simulates a head-dependent flux boundary for each cell to which it is assigned, and discharge is a function of simulated water level and boundary conductance (McDonald and Harbaugh, 1988, fig. 45). Unlike drains, general-head boundaries also allow inflow to the simulated system. This is a necessary requirement at the south end of the valley during transient simulation to adequately simulate the reversal in gradient in that area. Data required for the GHB Package are altitude and conductance. Neither of these are known. Mud Springs Canyon and Iron Springs Gap are both narrow canyons that flow toward the topographically lower Beryl-Enterprise area. The GHB altitude in those areas was set at an altitude of the streams part way through the canyons about $40 \mathrm{ft}$ below water levels near the boundaries. The south end of the model area is a very low surface- and ground-water divide. The altitude of the GHB at the south end of the valley was assigned a value only a few feet less than measured steady-state water levels to allow outflow during the steady-state simulation and inflow during the transient simulation. This model was constructed such that the conductance factor listed in the GHB Package input file is the length of the boundary in each cell. The MODFLOW-2000 GHB parameter (ghb) is multiplied by the conductance factor to obtain GHB conductance for each cell. Input to the GHB Package was 


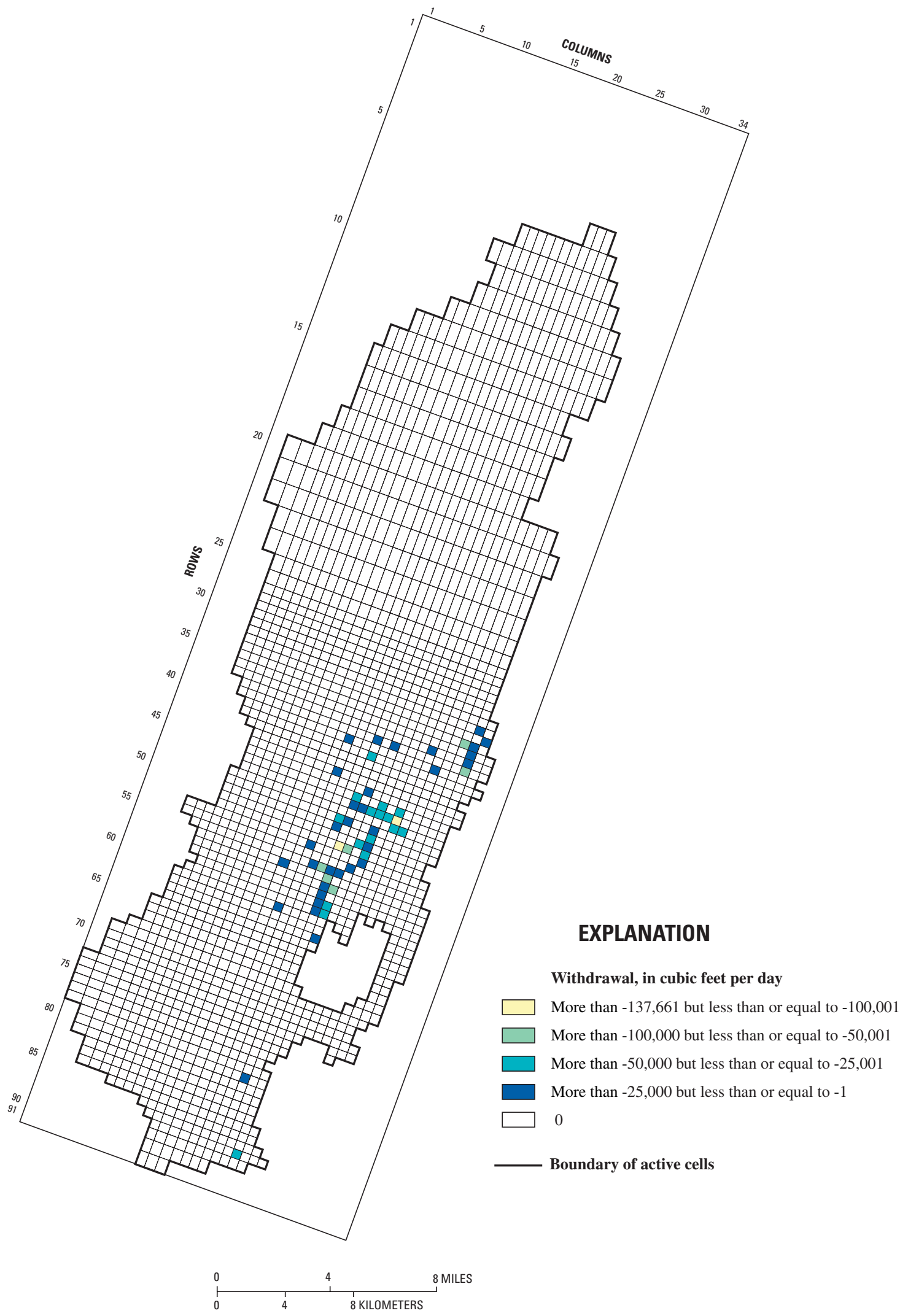

Figure 32. Distribution of withdrawal from wells simulated in the steady-state ground-water flow model, Cedar Valley, Iron County, Utah. 


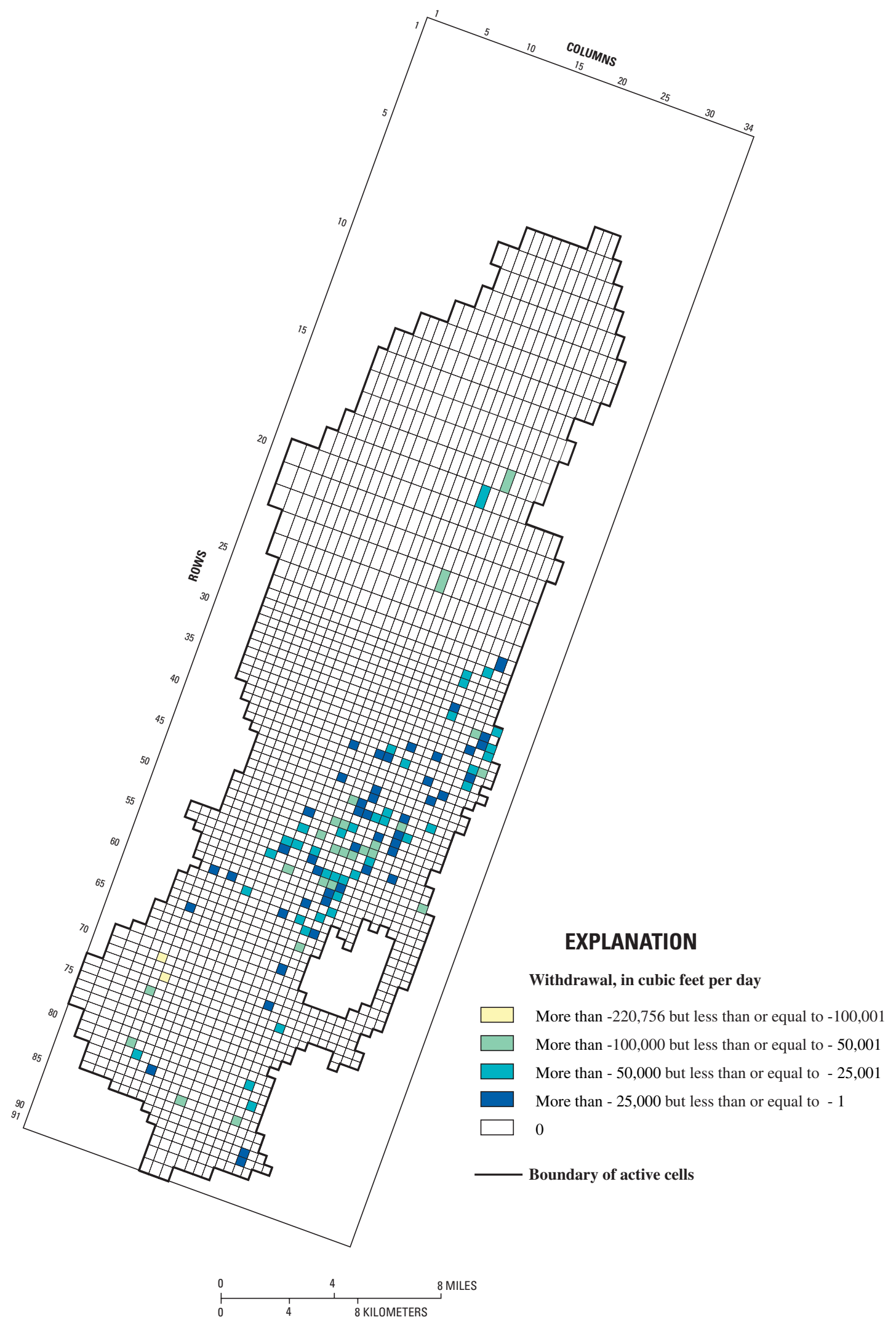

Figure 33. Distribution of withdrawal from wells simulated for 2000 in the transient ground-water flow model, Cedar Valley, Iron County, Utah. 


\section{Hydrology and Simulation of Ground-Water Flow in Cedar Valley, Iron County, Utah}

not changed during the transient simulation, but flow through the GHBs will vary as simulated water levels vary.

Discharge to springs is simulated near Enoch (fig. 31) with the Drain Package (Harbaugh and others, 2000, p. 71). Simulated springs are in layer 1 near where ground-water discharge was estimated in 1939 by Thomas and Taylor (1946, p. 103). The Drain Package simulates a head-dependent flux boundary for each cell to which it is assigned, and discharge is a function of simulated water level and drain conductance (McDonald and Harbaugh, 1988, fig. 41). Data required for the Drain Package are altitude and conductance of the drain. This model was constructed such that the conductance factor listed in the Drain Package input file is the area of the drain in each cell. The MODFLOW-2000 drain parameter (sprenoch) is multiplied by the conductance factor to obtain drain conductance for each cell. Input to the Drain Package was not changed during the transient simulation, but discharge to drains will vary as simulated water levels vary.

\section{Model Calibration}

The purpose of calibration is to develop a model that reasonably represents ground-water recharge, movement, and discharge, and reasonably matches measured water levels. The differences between simulated and measured water levels and flows should be acceptable for the intended use of the model. This model has been developed to simulate general ground-water flow throughout Cedar Valley and long-term water-level fluctuations. It should adequately represent basin-wide responses to changes in irrigation and ground-water withdrawals, but has not been developed to simulate local effects. The model is a simplified representation of the ground-water system and does not represent local heterogeneity in aquifer properties, recharge, or discharge. Cell-by-cell flow rates are not considered to be an accurate representation of ground-water movement on a small scale. In general, ground-water flow models can be considered more accurate representations of the groundwater system in areas where the most flow and water-level data are available. For Cedar City, this area is in the middle of the valley, generally between Cedar City and Enoch. Because of the lack of data north of Rush Lake, the model may not be well calibrated in that area and estimates of flow rates, water levels, or changes in the ground-water system in that area are considered less accurate.
To determine recharge and discharge rates; value and distribution of hydraulic conductivity; and conductance of drains, general-head boundaries, and horizontalflow boundaries, the model was calibrated to steady-state conditions. Some of these values also were adjusted during transient calibration because more data were available that indicated a different value or distribution. The final steady-state calibration was an iterative process with the transient simulation. Ground-water levels measured in March 1939 and March 1950, and the conceptual ground-water budget for the steady-state period were compared to simulated values to determine if the model adequately simulates the ground-water system as it was in the late 1930s and 1940s. MODFLOW-2000 calculates simulated values of water levels at the location of input observations, then calculates the difference between observation values and simulated values, weighted residuals, and other statistical measures of model fit. Ninety water levels and one spring discharge were used as observations for the steady-state simulation.

During transient calibration, adjustments were made to the value and distribution of specific yield and specific storage. Adjustments also were made to other parameters, requiring an equivalent change in the steadystate simulation. Adjustments to hydraulic conductivity and horizontal-to-vertical anisotropy were made mostly in areas that have withdrawal during transient simulation but not during steady-state simulation. The imposed stress on the system during transient simulation accentuates the importance of the hydraulic properties. The altitude of the general-head boundary at Iron Springs Gap was adjusted during calibration of the transient model because water levels were not available in that area during calibration of the steady-state model. Water-level data collected in March from 1939 to 2001 were used as observations in the transient simulation. At wells with more than one water level measurement, the change in water level between measurements was used as an observation instead of the water level. This removed error associated with land-surface altitude and put more emphasis on the simulation matching long-term waterlevel fluctuations and on the sensitivity of water-level fluctuations to model parameters. In the transient simulation, an additional 780 water-level observations were used. The simulated budget was compared to the conceptual budget for the year 2000 to determine if the transient simulation adequately represented changes in the groundwater system through time. 


\section{Parameter Adjustment and Sensitivity}

During model calibration, parameters were adjusted to achieve a model that reasonably represents the ground-water system by minimizing the sum of squared errors between simulated and measured water levels, while still simulating approximate known or estimated water-budget components. Recharge from irrigation, specific yield, hydraulic conductivity, and vertical anisotropy were adjusted both by modifying the distribution of the parameters with zone arrays and by changing the parameter values. Inflow from consolidated rock was adjusted by changing the parameter values. Evapotranspiration was adjusted both by modifying the distribution of maximum evapotranspiration rate with the multiplier array and by adjusting the parameter values. Drain conductance, general-head boundary conductance, and horizontal-flow barrier conductance were adjusted by modifying the parameter values. The location of drains, general-head boundaries, and horizontal-flow barriers also were adjusted slightly.

The sensitivity of observations to parameters was used to aid model calibration. Composite scaled sensitivities can be used to evaluate whether available observations provide adequate information to estimate each parameter and can provide an overall view of the parameters to which the observations are most sensitive (Hill and others, 2000, p. 96). To determine which model parameters may need the most refinement, the steady-state model initially was constructed to have one parameter for each source of recharge and discharge and for each hydraulic characteristic. Simulated values at observation locations were more sensitive to recharge from irrigation and discharge to wells than to any other model parameter (fig. 34). Because all sources of recharge and discharge were defined as parameters, many pairs of model parameters had correlation coefficients of 1.0. This indicated that a unique model would be impossible to define.

Although ground-water withdrawal data are not exact, the rate of ground-water withdrawal is probably better known than the rate of recharge from irrigation or hydraulic conductivity; therefore, pumpage was assumed to be correct as estimated in the conceptual budget and pumpage from wells was deleted as a model parameter. This eliminated any correlation coefficients greater than 0.92 . The high sensitivity of observations to recharge from irrigation and hydraulic conductivity indicated that the model may be more accurate if those parameters were divided into multiple parameters that could be independently adjusted. Because of the high sensitivity, more effort was made to refine estimates of recharge from irrigation and hydraulic conductivity than other calibration parameters. Some other parameters were divided and refined mostly to allow variation to achieve a better match between simulated water levels and observed water levels in local areas, even though the composite scaled sensitivities are not high. Observations are relatively insensitive to some model parameters (fig. 34); as a consequence, those parameters may not be estimated correctly in the simulation.

\section{Irrigation Zones}

Recharge from irrigation was refined by assigning a recharge parameter to each of five irrigation zones defined by a zone layer. The zones represent areas with different recharge scenarios in the conceptual budget. Parameter coalirr1 applies mostly to the Union and North Field areas and Enoch City; parameter coalirr2 applies mostly to areas with low priority rights to Coal Creek water; parameter coalseep applies in the Cedar City area, which also includes seepage from Coal Creek and recharge from municipal irrigation; parameter shirts applies to areas irrigated with water from Shirts and Murie Creeks; and parameter wellirr applies to areas that receive irrigation only from ground water (fig. 29) and discharge from the waste-water treatment plant. The multiplier array defining conceptual recharge rates was not adjusted during calibration. Instead, the value of each parameter was adjusted independently of the other recharge parameters. This allowed the recharge rates in each zone to be adjusted by a constant factor. The initial value assigned to all parameters was 0.00274 to simulate conceptual recharge rates in $\mathrm{ft} / \mathrm{d}$, but the final values of the five parameters are different (fig. 29).

\section{Hydraulic Conductivity}

Five hydraulic-conductivity parameters were used and assigned to different areas with a zone array. Both the distribution and the value of the parameters were adjusted during model calibration to cause simulated water levels to more closely match observed water levels. The initial distribution of the parameters was based on the surficial geology (Hurlow, 2002, pl. 1), with the assumption that basin-fill alluvium in the center of the valley had a smaller hydraulic conductivity than did alluvial-fan deposits near the mountains. The final distribution of hydraulic conductivity (fig. 27) does not exactly follow the surficial geology. It is reasonable, however, that hydraulic conductivity changes within surficial geologic units and that deeper units also influence ground-water movement. 


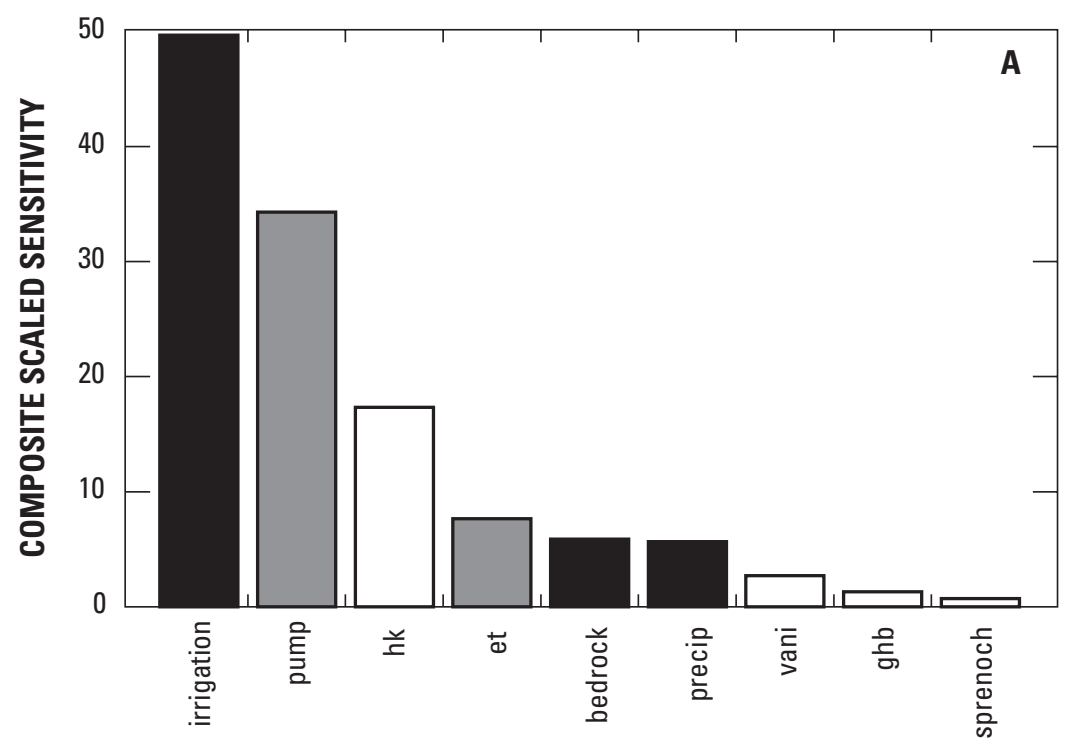

EXPLANATION

Recharge parameter

Discharge parameter

Aquifer characteristics parameter

\begin{tabular}{|ll|}
\hline Parameter & \multicolumn{1}{c|}{ Parameter for: } \\
\hline irrigation & Recharge from irrigation \\
pump & Withdrawal from wells \\
hk... & Horizontal hydraulic conductivity \\
et & Maximum evapotranspiration rate \\
bedrock... & Inflow from consolidated rock \\
precip & Recharge from precipitation \\
vani... & Horizontal-to-vertical anisotropy \\
ghb & General-head boundaries \\
sprenoch & Hydraulic conductivity of springs \\
coalirr... & Recharge from irrigation with Coal Creek \\
coalseep & Seepage from Coal Creek \\
shirts & Recharge from irrigation with Shirts Creek \\
parowan & Inflow from Parowan Valley \\
wellirr & Recharge from irrigation with ground water \\
hfb & Horizontal flow barriers \\
\hline
\end{tabular}

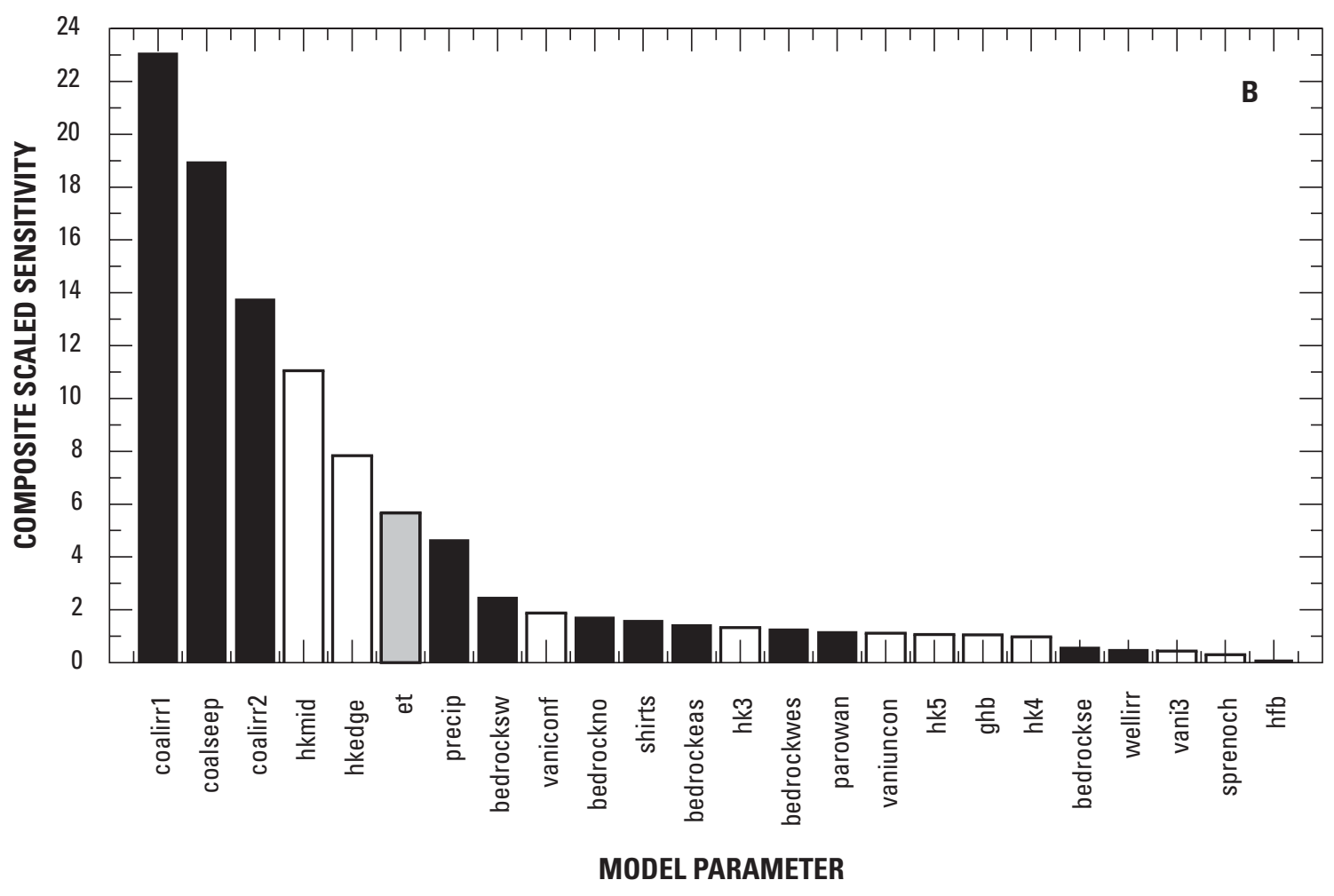

Figure 34. Composite scaled sensitivity of observations to $(A)$ original, and (B) final model parameters simulated in the steady-state ground-water flow model, Cedar Valley, Iron County, Utah. 
Three parameters were used to describe the horizontal-to-vertical anisotropy of hydraulic conductivity. Both the distribution and value of the parameters were adjusted during calibration to better simulate observed water levels and to create vertical gradients. The final distribution of horizontal-to-vertical anisotropy of hydraulic conductivity is shown in figure 35. Simulated values range from 4 to 2,500 . It is probable that the value of 2,500 represents areas where clay layers or lenses inhibit the vertical movement of ground water. It is not thought that sand and gravel layers have such extreme anisotropy. The two areas with the value of 2,500 have declining water levels from pumpage in layer 2 . The simulated levels do not decline as much as observed levels unless water is inhibited from moving downward from layer 1 to layer 2.

\section{Evapotranspiration}

Simulated values at observations are sensitive to the evapotranspiration parameter (et), but are not sensitive enough (fig. 34A) to warrant dividing the parameter into additional parameters for different areas. A multiplier array was used, however, to areally vary the maximum rate of evapotranspiration. The multiplier array (fig. 31 ) and the evapotranspiration parameter were adjusted during calibration. Two parameters (et1 and et2) were used because the area of evapotranspiration changes during the transient simulation. The consumptive use of crops is already subtracted from the amount of irrigation water applied ("Recharge from irrigation" section of this report), and evapotranspiration is not simulated from irrigated lands. Because ground-water withdrawal and irrigated area increased in the 1960s, simulation of evapotranspiration in those irrigated lands should cease in the transient simulation. This was accomplished by having parameter et 1 applied to areas not irrigated from 1938 to 1959 and parameter et2 applied to areas not irrigated from 1960 to 2000. Generally, the ground-water irrigation areas added after 1949 (fig. 23) are included in parameter et 1 and are not included in parameter et 2.

\section{Inflow from Consolidated Rock and Parowan Valley}

Although water levels may not be sensitive enough to inflow from consolidated rock to justify dividing the parameter into additional parameters (fig. 34A), it was of interest to know the sensitivity to inflow from different locations and to be able to vary the amount of inflow from different locations during calibration. Therefore, the parameter was divided into six parameters. Final values of the parameters (fig. 30) significantly reduce the simulated amount of inflow compared to the conceptual bud- get. The simulated values are uncertain because of the lack of independent data to determine inflow from consolidated rock and Parowan Valley. The low composite scaled sensitivities (fig. 34B) of the inflow parameters indicate they could be estimated incorrectly.

\section{Other Parameters}

The parameter representing recharge from precipitation was increased from 0.00274 to 0.003 during calibration. This resulted in changing recharge from precipitation from $0.035 \mathrm{ft} / \mathrm{yr}$ to the final value of 0.038 $\mathrm{ft} / \mathrm{yr}$. The parameters representing conductance of drains, general-head boundaries, and horizontal-flow barriers also were adjusted during calibration. Generally, simulated water levels at observations are not very sensitive to these parameters (fig. 34B). The drain parameter was increased to simulate discharge to the springs that more closely matched observed discharge.

\section{Specific Yield}

Two parameters were assigned to each of two zones of specific yield and specific storage. The zones roughly corresponded to the coarser- and finer-grained basin fill. Specific yield originally was assigned values of 0.2 and 0.1 , and specific storage initially was assigned values of $1 \times 10^{-5}$ and $1 \times 10^{-6}$. Both the distribution and value of the parameters were adjusted during model calibration. In some areas, the value of specific yield changes within a geologic unit. This was done purely to aid model calibration and is not based on aquifer tests or more detailed geology. It is reasonable, however, that specific yield varies within surficial geologic units and that deeper units also influence ground-water flow. The final distribution of specific yield is shown in figure 36 . These values are uncertain because of the lack of aquifer-test data to determine these parameters independently of the model.

\section{Steady-State Calibration}

Overall, the steady-state ground-water flow model adequately simulates water levels observed in March 1939 and March 1950. Simulated levels are within $5 \mathrm{ft}$ of most observed water levels and more than $5 \mathrm{ft}$ different from only 16 observed levels (fig. 37). The residuals are normally distributed and high and low simulated values are evenly spread throughout the simulated area. Groundwater flow indicated by contours of simulated water levels is similar to ground-water movement indicated by 


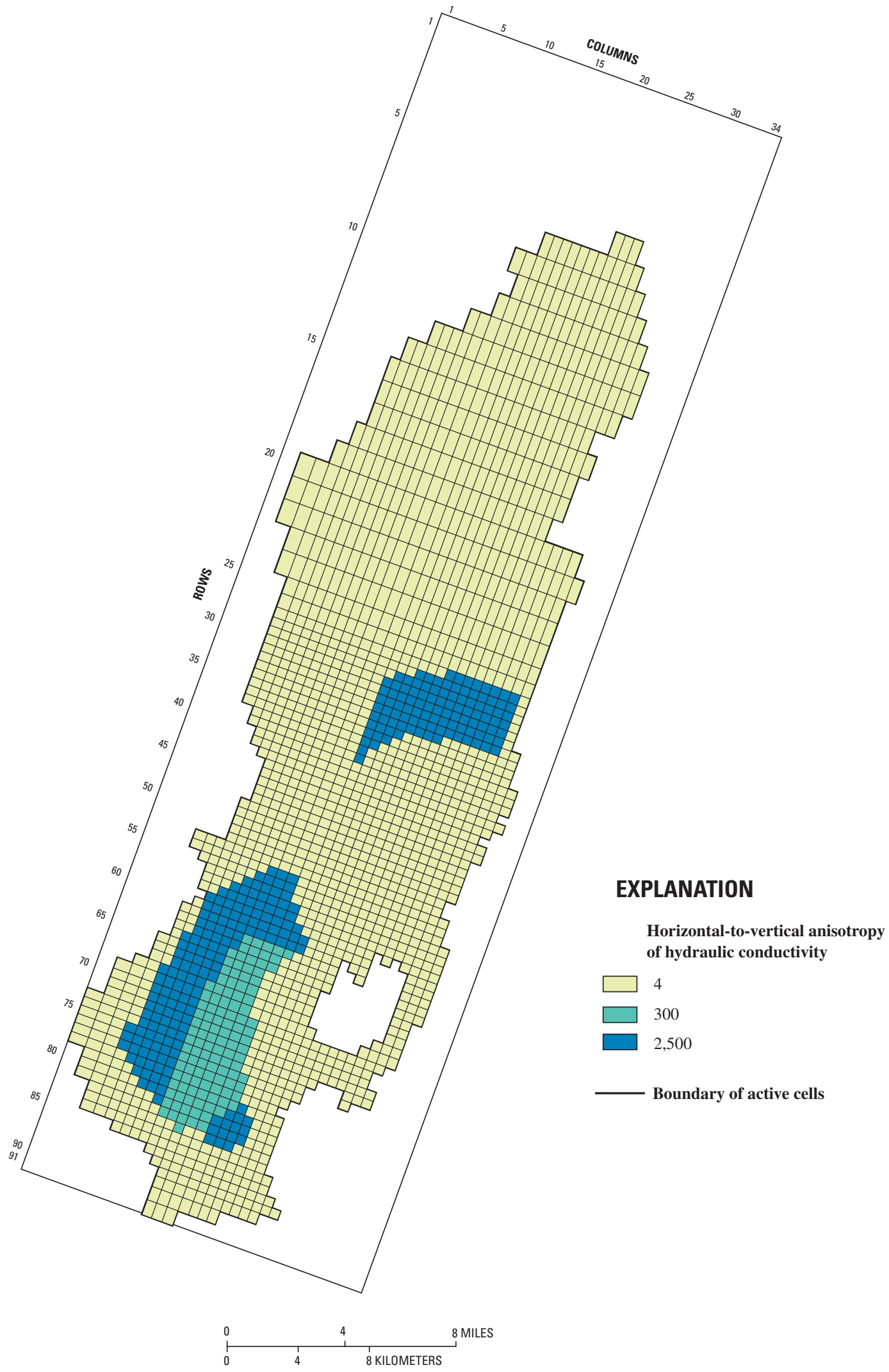

Figure 35. Final distribution of horizontal-to-vertical anisotropy of hydraulic conductivity simulated in the ground-water flow model, Cedar Valley, Iron County, Utah. 


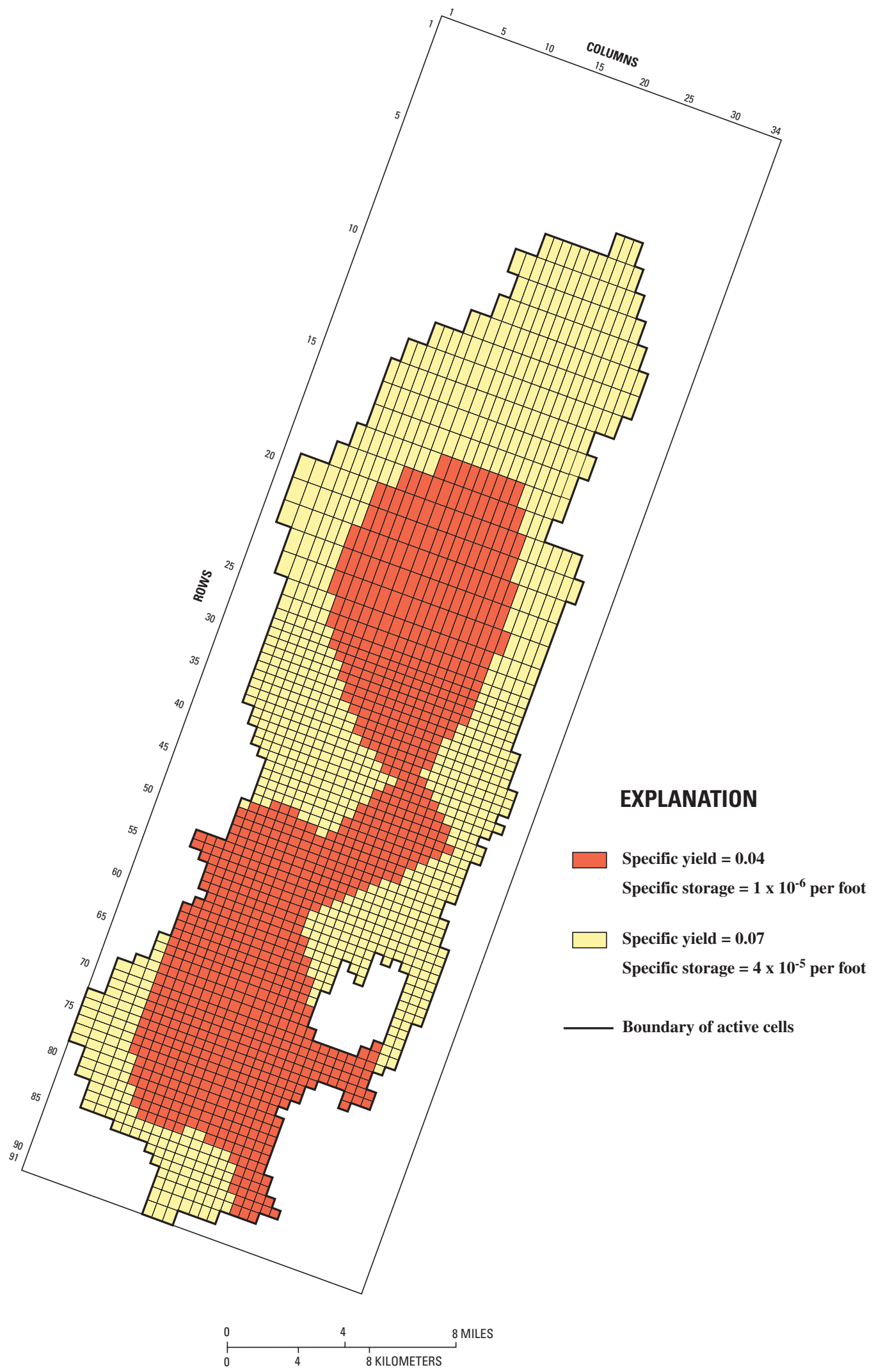

Figure 36. Final distribution of specific yield and specific storage simulated in the ground-water flow model, Cedar Valley, Iron County, Utah. 


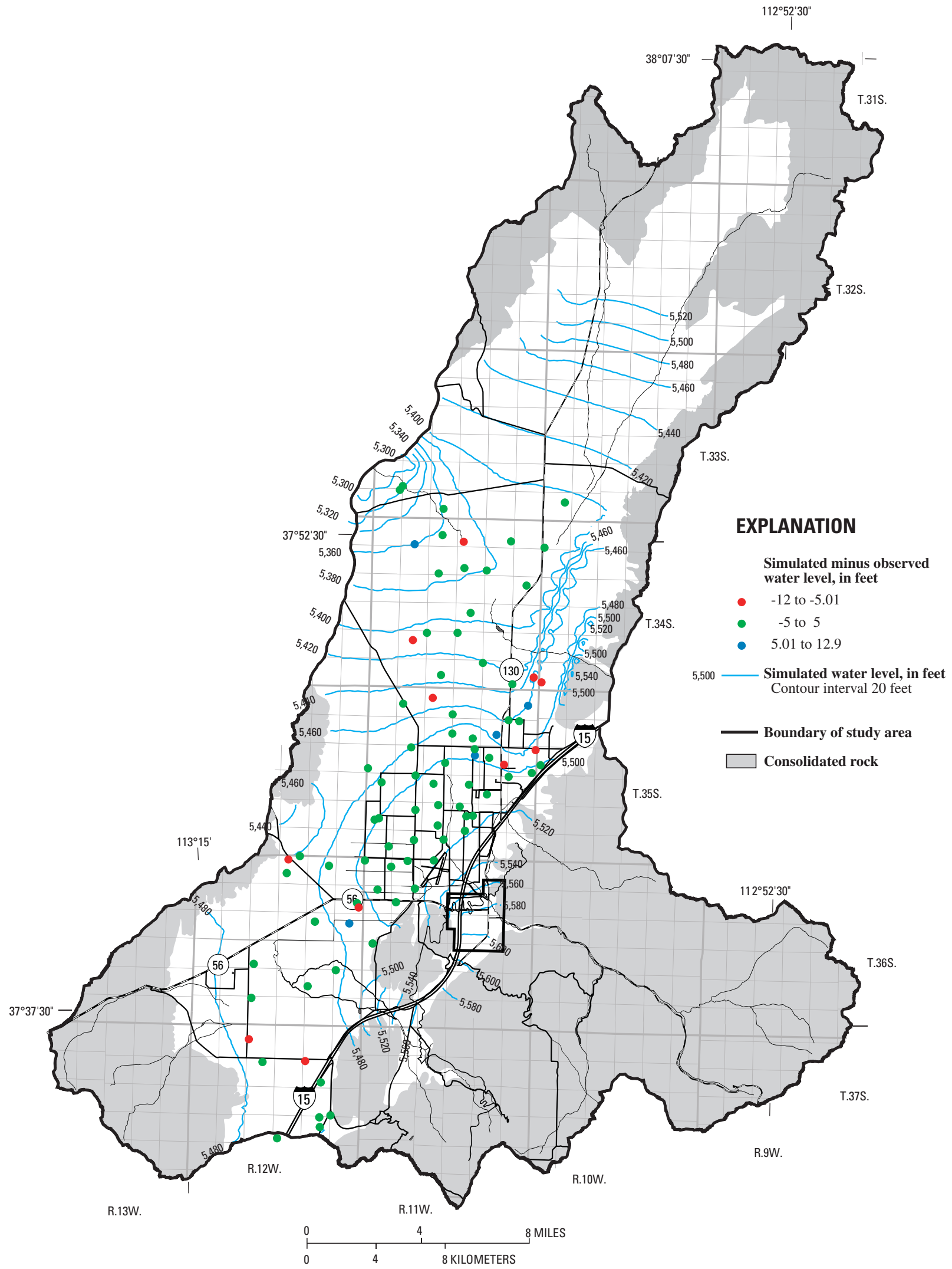

Figure 37. Water level simulated in the steady-state ground-water flow model, and difference between simulated water level and water level measured in March 1939 and March 1950, Cedar Valley, Iron County, Utah. 
contours of measured water levels (Thomas and Taylor, 1946, pl. 14). Similarities between simulated water levels and measured water levels indicate that most recharge and discharge is adequately simulated and that the simulated distribution of hydraulic characteristics adequately represents the ground-water system.

Conceptual and simulated ground-water budgets are presented in table 14 . The steady-state model simulates less recharge and discharge than estimated in the conceptual budget, but is an adequate approximation of the conceptual ground-water flow system, especially given the uncertainties in recharge from irrigation and consolidated rock and discharge by evapotranspiration in the conceptual budget. The simulated rates of areal recharge (irrigation and precipitation) and discharge to wells, springs, and other areas are similar to conceptually estimated rates. Inflow from Parowan Valley, northern consolidated rock, and southeastern consolidated rock is substantially less than that conceptually estimated. This difference in recharge is accounted for in the steady-state simulation by a decrease in evapotranspiration, which is much less than conceptually estimated.

Although the simulated rate of recharge from irrigation and precipitation is similar to the conceptual rate, some differences are observed on an area-by-area basis. The calibrated steady-state model simulates less recharge in the Cedar City area, more recharge on the east side of the valley, and significantly less recharge in the area north of Kanarraville than conceptually estimated. The conceptual estimate for the area north of Kanarraville was based on the recharge rates of other areas, but it is doubtful whether that much water is normally available for irrigation. Lack of perennial streamflow in the area indicates the simulated recharge may be more accurate.

\section{Transient Calibration}

The main emphasis of the transient calibration was to adjust the model to more accurately simulate measured water-level fluctuations. Twenty long-term hydrographs

Table 14. Conceptual ground-water budget for 1938-49, and ground-water budget simulated in the steady-state ground-water flow model, Cedar Valley, Iron County, Utah

[Conceptual flow as shown in table 2 may differ because method of calculating recharge from irrigation changed during model calibration]

\begin{tabular}{|c|c|c|c|c|c|}
\hline \multirow[b]{2}{*}{ Budget component } & \multicolumn{2}{|c|}{ Conceptual flow } & \multirow[b]{2}{*}{ Method of simulation } & \multicolumn{2}{|c|}{ Simulated flow } \\
\hline & $\begin{array}{l}\text { (acre-feet } \\
\text { per year) }\end{array}$ & $\begin{array}{c}\text { (cubic feet } \\
\text { per day, rounded) }\end{array}$ & & $\begin{array}{l}\text { (acre-feet } \\
\text { per year) }\end{array}$ & $\begin{array}{c}\text { (cubic feet } \\
\text { per day, rounded) }\end{array}$ \\
\hline $\begin{array}{l}\text { Irrigation and precipitation on } \\
\text { irrigated lands, including seepage } \\
\text { from Coal Creek }\end{array}$ & 22,100 & $2,600,000$ & Areal recharge in Recharge Package & 19,100 & $2,280,000$ \\
\hline North consolidated rock & 3,500 & 420,000 & Specified flux in Well Package & 1,100 & 130,000 \\
\hline Southeast consolidated rock & 2,900 & 350,000 & Specified flux in Well Package & 300 & 33,000 \\
\hline East consolidated rock & 600 & 69,000 & Specified flux in Well Package & 600 & 69,000 \\
\hline Southwest consolidated rock & 1,200 & 140,000 & Specified flux in Well Package & 1,300 & 160,000 \\
\hline West consolidated rock & 800 & 95,000 & Specified flux in Well Package & 800 & 99,000 \\
\hline Wells & 13,200 & $1,600,000$ & Specified flux in Well Package & 13,300 & $1,600,000$ \\
\hline Springs & 4,300 & 510,000 & Head-dependent flux in Drain Package & 1,700 & 210,000 \\
\hline Outflow to other areas & 1,000 & 240,000 & $\begin{array}{l}\text { Head-dependent flux in General-Head } \\
\text { Boundary Package }\end{array}$ & 3,500 & 410,000 \\
\hline Total (rounded) & 40,000 & $4,900,000$ & & 31,600 & $3,800,000$ \\
\hline
\end{tabular}

\footnotetext{
${ }^{1}$ Reduced from table 2 to provide a balanced budget for the steady-state model.

${ }^{2}$ Includes 900 acre-feet per year recharge from consolidated rock.
} 
were chosen to compare with simulated water levels. These hydrographs are grouped as north and west of Enoch, near Enoch, center of valley, near Cedar City, and south. Individual well hydrographs probably are influenced by local ground-water withdrawals. Incorrect estimates of annual withdrawals at individual wells may contribute to some of the difference between measured and simulated water levels.

North of Enoch, measured annual water-level fluctuations are small, which indicates little fluctuation in annual recharge in this area (fig. 38, hydrographs A-F). Long-term water-level declines, however, have occurred in some wells since the late 1950s, which indicate that discharge exceeds recharge in this area, possibly because of increased pumpage south of this area. The model accurately represents the small annual water-level fluctuations, but not the long-term water-level declines in this area. The exception is near well (C-34-10)31caa-1 (fig. 38 , hydrograph $\mathrm{E}$ ), where simulated water levels decline more than measured water levels. This well is in a geologically complex area of faults and basalt flows that may not be defined correctly in the model.

Near Enoch, measured annual water-level fluctuations are larger than in the north and show more response to the years of greater-than-normal precipitation in the 1980s. Water levels rose about $20 \mathrm{ft}$ from March 1978 to March 1989. Simulated water levels in the area (fig. 38, hydrographs $\mathrm{G}$ and $\mathrm{H}$ ) rose more than measured levels during the 11-year period. Simulated water levels do not decline as much as measured levels from 1998 to 2001. Decreasing simulated recharge from irrigation or bedrock inflow in this area did not cause much more decline, and the lack of simulated decline in recent years is not understood.

Large measured annual water-level fluctuations near, north, and west of Cedar City but south of Enoch are in response to changing flow in Coal Creek. This is the area of low priority water rights, and application of surface water changes dramatically with the flow in Coal Creek. Water levels increased between 27 and $42 \mathrm{ft}$ from 1978 to 1985 (fig. 38, hydrographs I-M). Simulated water levels match this rise and also match annual fluctuations. The accurate simulation of water-level fluctuations in this area supports the concept of recharge being dependent upon applied water exceeding consumptive use.

Most measured annual water-level fluctuations in wells farther west and south of Cedar City are not as large as the fluctuations closer to Cedar City (fig. 38, hydrographs N-P). These wells are outside of the area of most surface-water irrigation and respond less to yearly changes in recharge. The model accurately simulates water levels in most of this area. South of Cedar City near well (C-36-12)25bdd-1, simulated water levels do not decline as much as measured water levels during years with less-than-normal precipitation and increased pumpage, but the model is still considered adequate in this area.

Near Quichapa Lake, measured water levels slowly rose about $15 \mathrm{ft}$ from 1978 to 1987 (fig. 38, hydrographs Q and R). Earlier water levels are not available. Simulated water levels are too high in 1979, rise less than and generally match measured levels from 1982 through 1996, then do not decline as much as measured levels. Close to the south boundary of the study area, simulated levels fluctuate more than measured levels in one well and match the few data in another well (fig. 38, hydrographs $\mathrm{S}$ and $\mathrm{T}$ ).

In addition to long-term hydrographs, the ability of the transient model to match March 2000 observed water levels also was evaluated (fig. 39). In general, the model adequately simulated the water levels and most simulated levels are within $10 \mathrm{ft}$ of the observed levels. Along the east side of the valley, however, many simulated values are significantly higher than observed levels. Reducing bedrock inflow or adjusting horizontal-to-vertical anisotropy of hydraulic conductivity does not significantly lower the simulated values, and reducing recharge from irrigation causes other simulated water levels to become too low. Storage also could not be adjusted without negatively affecting other water levels. This same area had several simulated water levels during the steady-state simulation that were lower than observed levels. The reversal at the end of the transient simulation may indicate that some time-varying stress is not accurately simulated in this area.

Along the eastern edge of the valley and near Quichapa Lake (fig. 39) some areas have simulated levels in 2000 that are higher than March observed levels but have simulated levels in the steady-state period (1938-49) that are similar or slightly lower than observed levels. Simulated drawdown from the steady-state period (193849) to the end of the transient simulation (2000) in these areas is 20 to $40 \mathrm{ft}$, which is typically about $20 \mathrm{ft}$ less than would be needed to match observed 2000 water levels. These are areas where ground-water withdrawals were either not occurring during the steady-state period or were much less than they are currently. The model does not seem to adequately represent the effects of the increased ground-water withdrawals in these areas. Most of the areas with the largest differences are near the consolidated-rock boundary. The complex heterogeneity of 


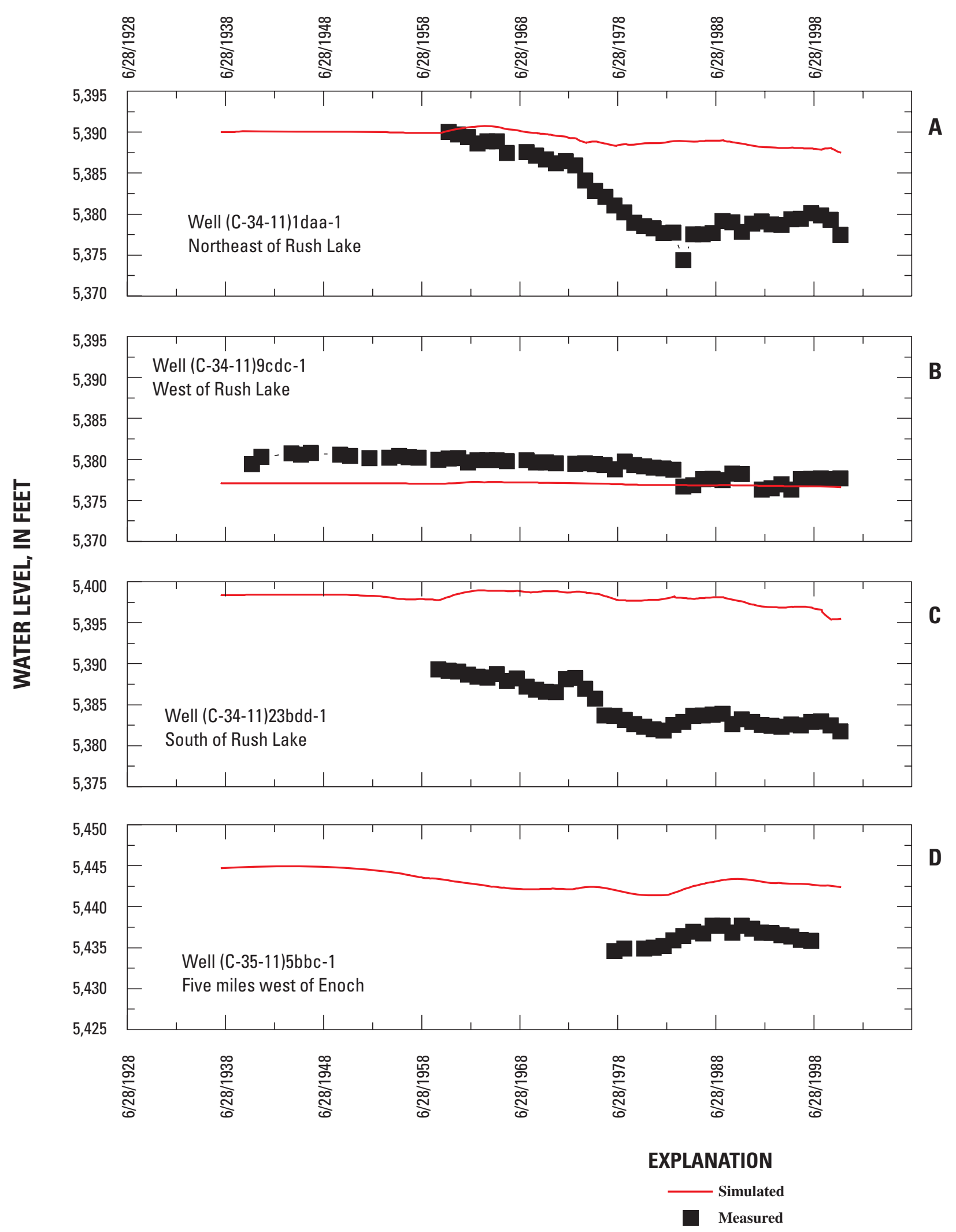

Figure 38. Water level simulated at the end of each stress period in the transient ground-water flow model and water level measured from March 1939 to March 2001, Cedar Valley, Iron County, Utah. 


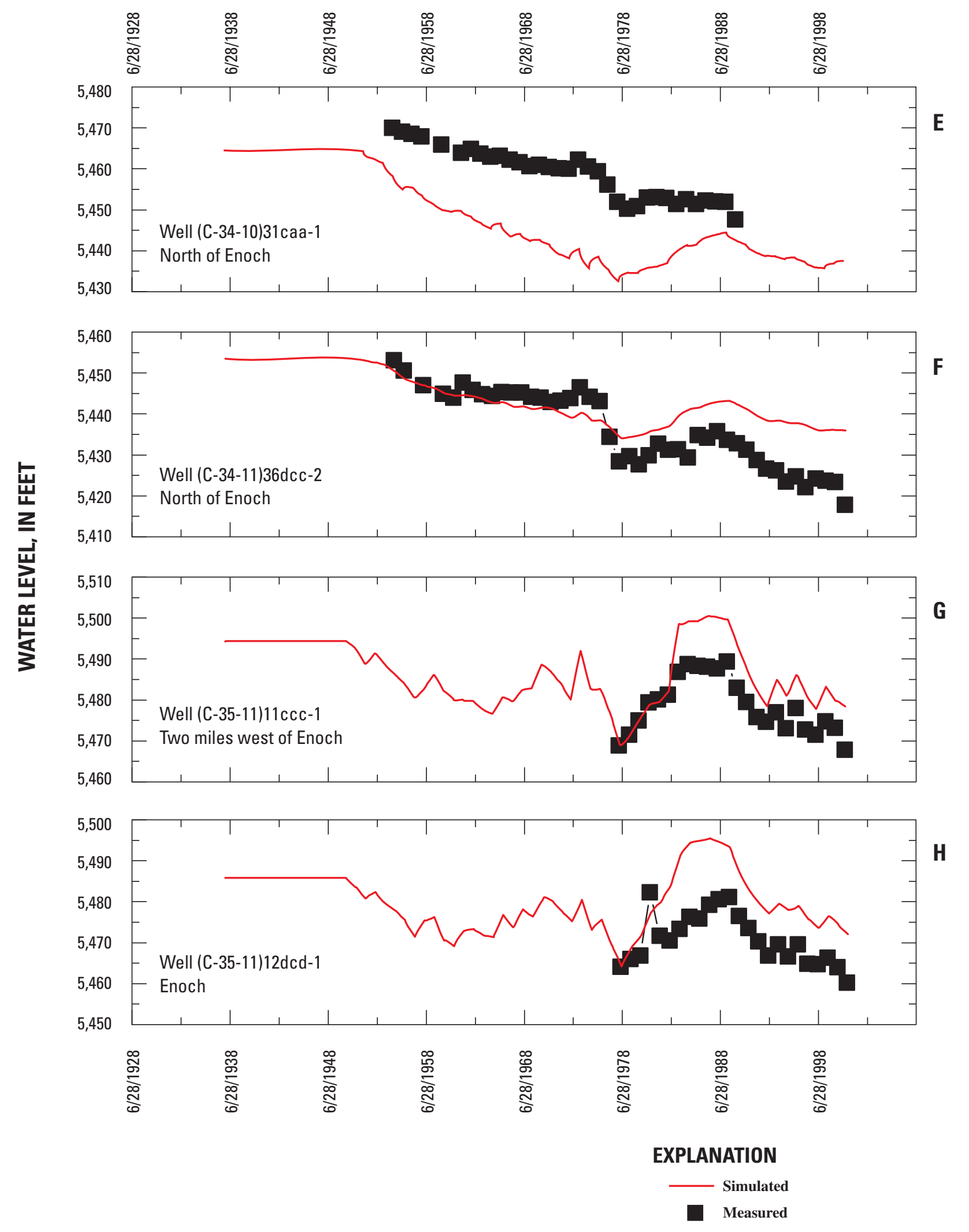

Figure 38. Water level simulated at the end of each stress period in the transient ground-water flow model and water level measured from March 1939 to March 2001, Cedar Valley, Iron County, Utah-Continued. 


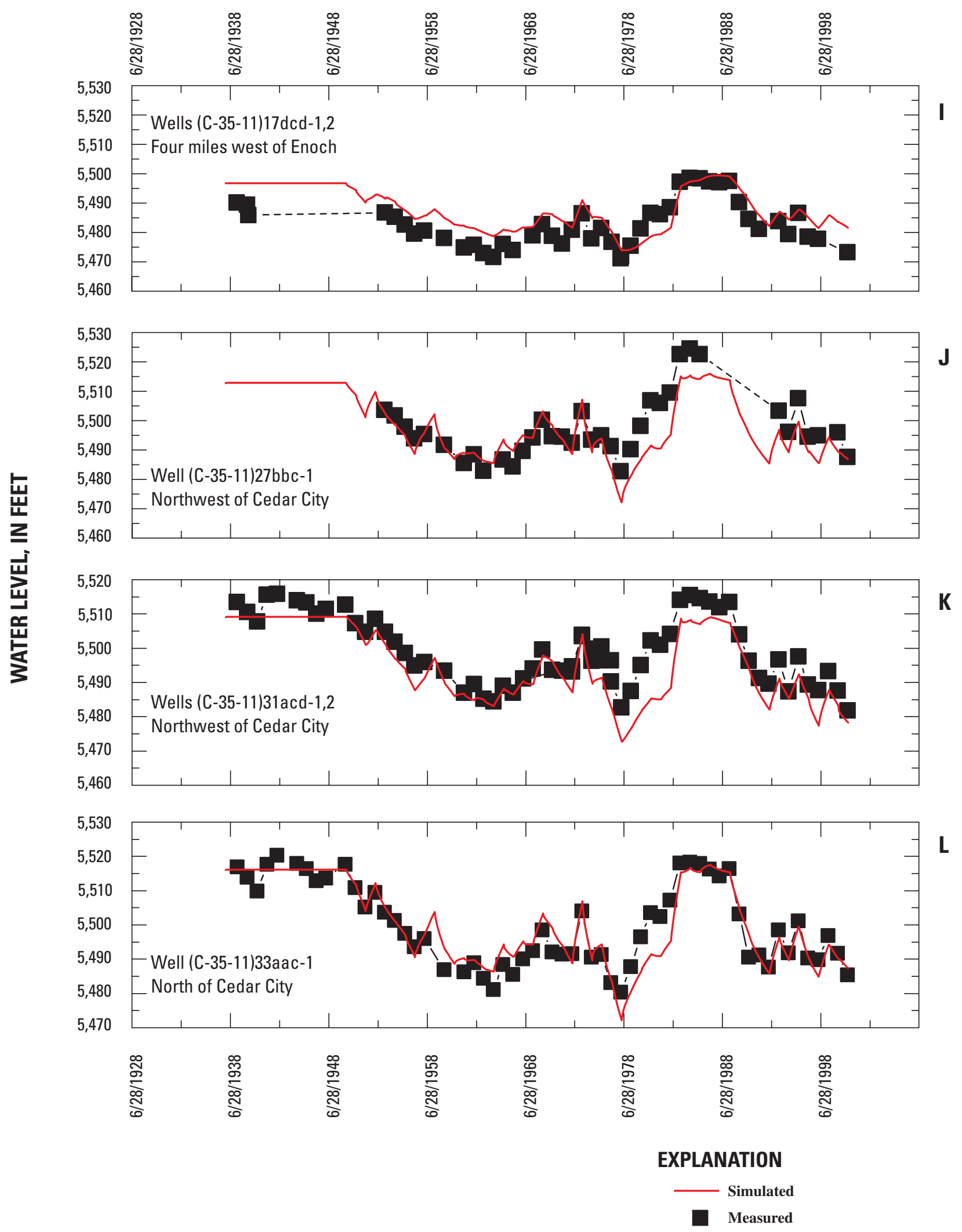

Figure 38. Water level simulated at the end of each stress period in the transient ground-water flow model and water level measured from March 1939 to March 2001, Cedar Valley, Iron County, Utah-Continued. 

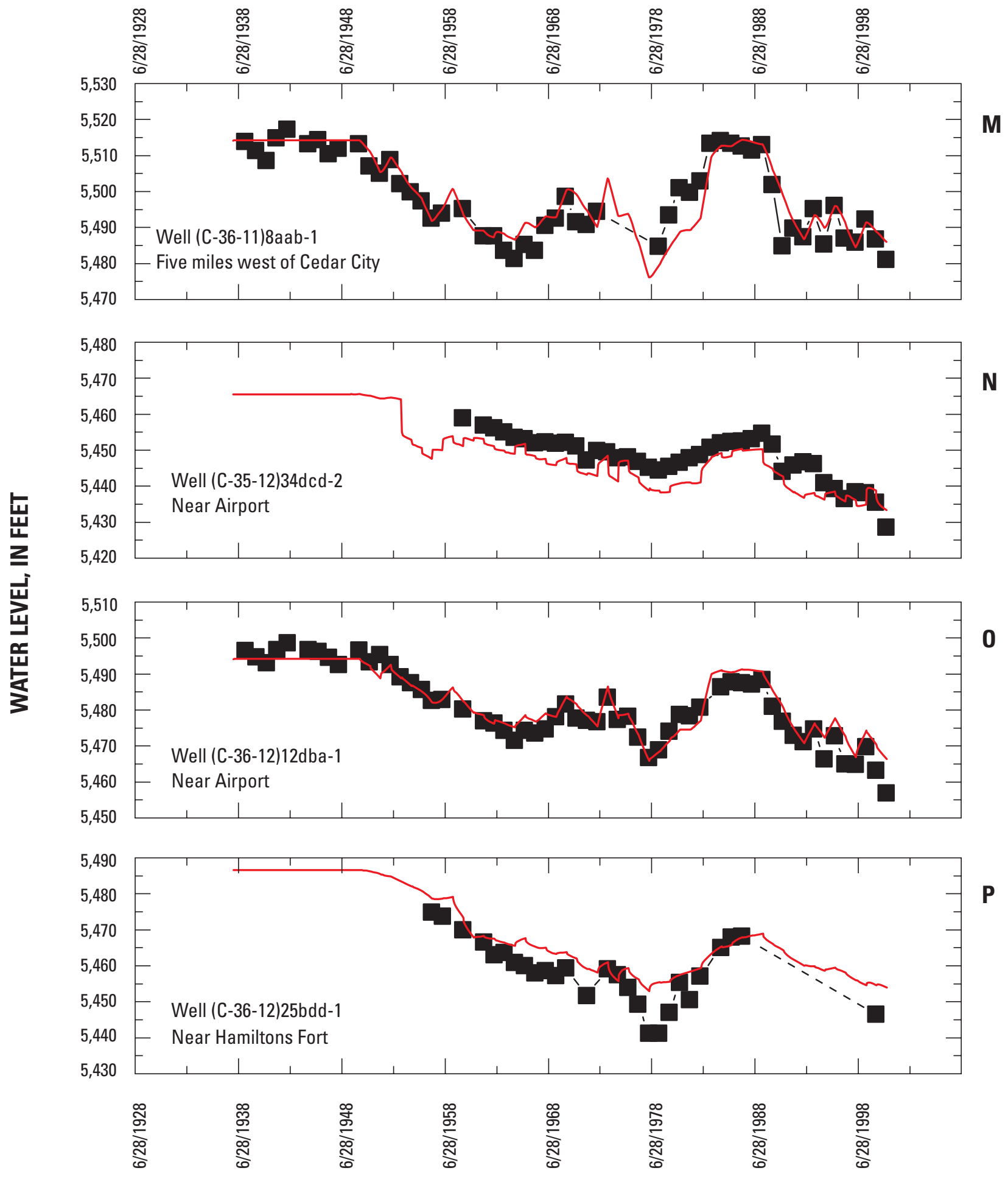

\section{EXPLANATION}

Simulated

Measured

Figure 38. Water level simulated at the end of each stress period in the transient ground-water flow model and water level measured from March 1939 to March 2001, Cedar Valley, Iron County, Utah—Continued. 


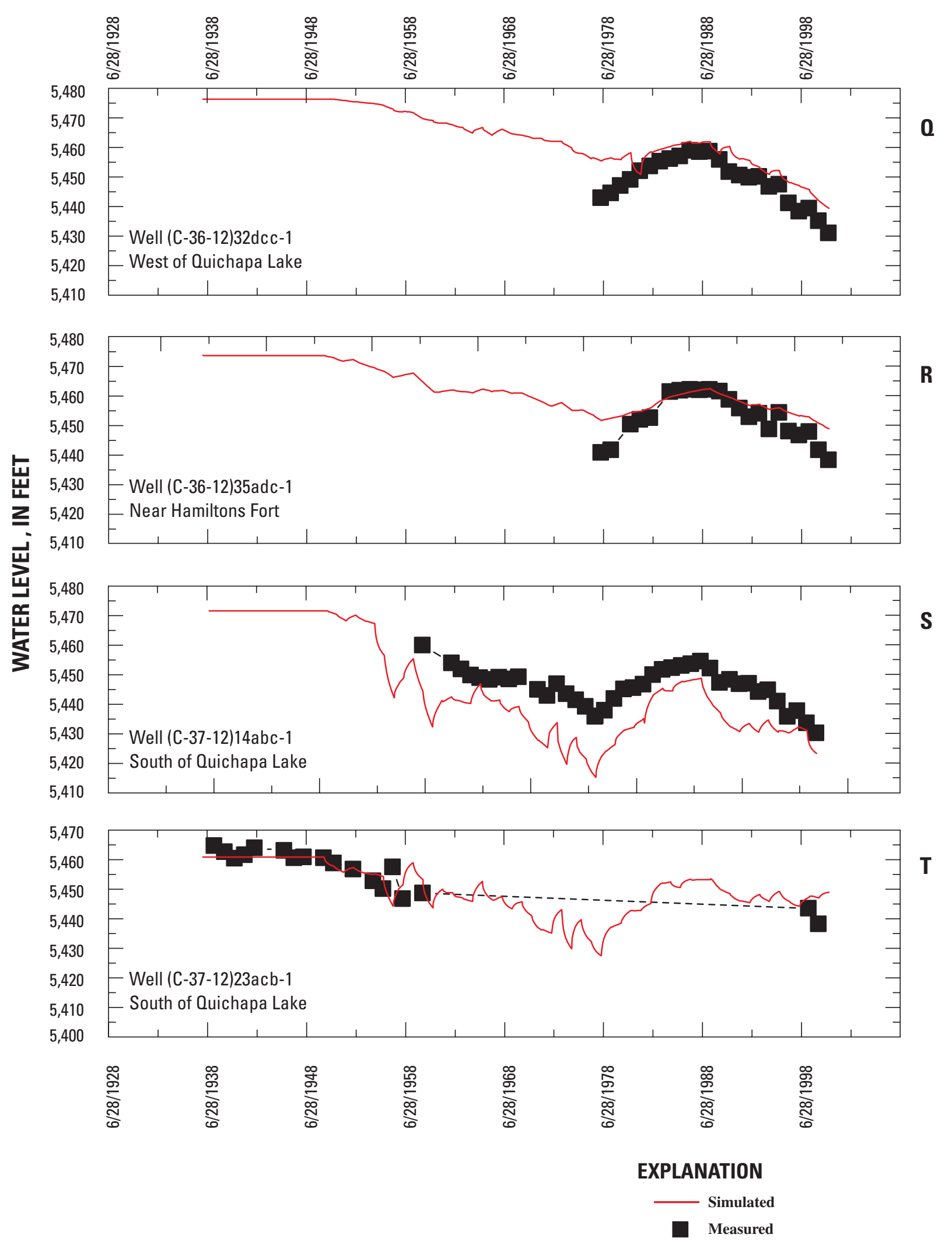

Figure 38. Water level simulated at the end of each stress period in the transient ground-water flow model and water level measured from March 1939 to March 2001, Cedar Valley, Iron County, Utah-Continued. 


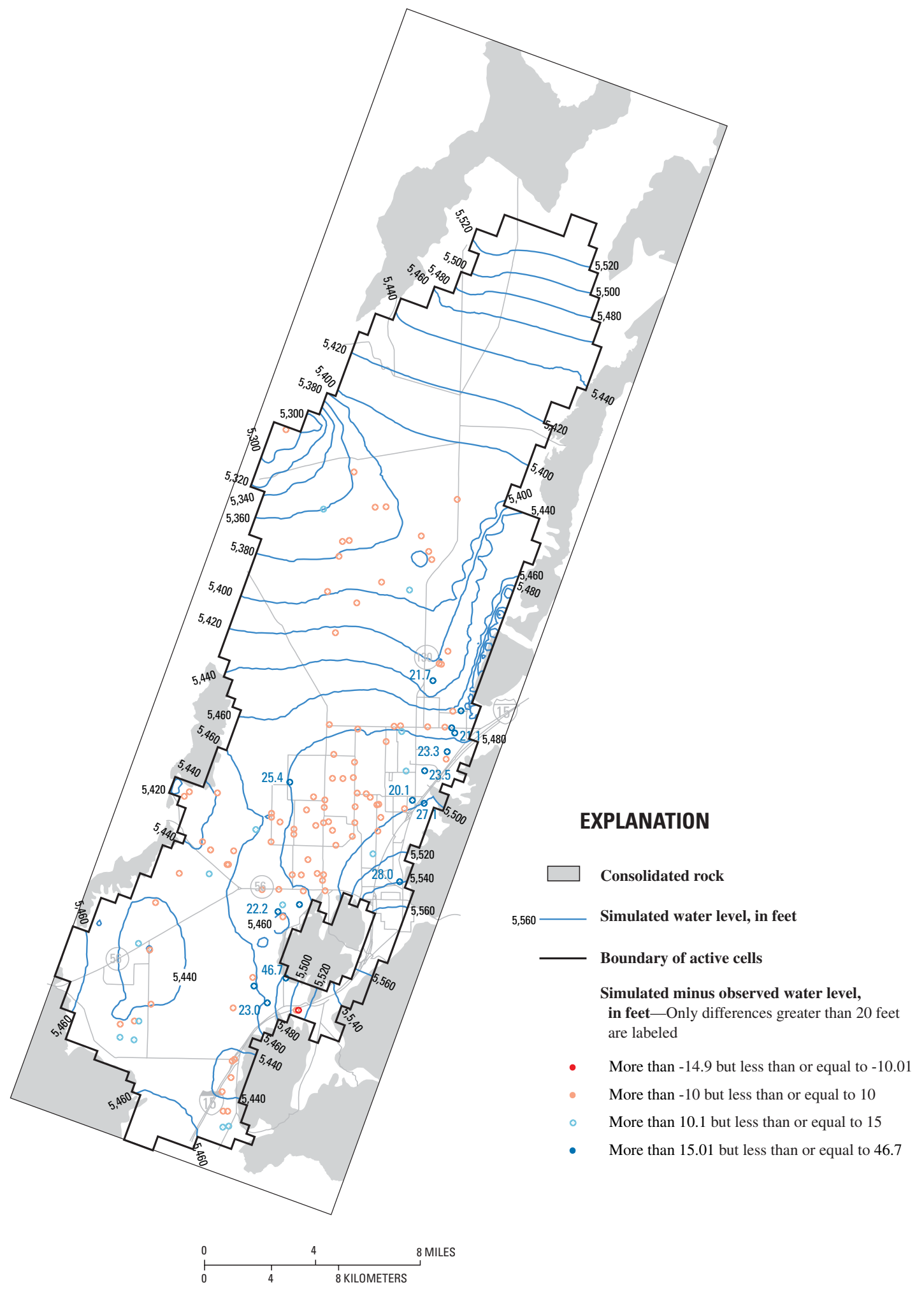

Figure 39. Water level simulated at the end of stress period 62 in the transient ground-water flow model and difference between simulated water level and water level measured in March 2000, Cedar Valley, Iron County, Utah. 
possible faults, landslide deposits, and other conditions that may occur locally may not be simulated correctly in this regional model.

In general, the model accurately simulates water levels and water-level fluctuations and can be considered an adequate tool to help determine the valley-wide effects on water levels of additional ground-water withdrawal and changes in water use. On the east side of the valley, and near Quichapa Lake, simulated effects may be less than actual effects.

The conceptual ground-water budget for 2000 is compared with the ground-water budget simulated for stress period 63 in the transient ground-water flow model in table 15. As in the steady-state period, simulated recharge is less than conceptual recharge; the main difference is inflow from consolidated rock. Conceptual and simulated inflow from consolidated rock is 122 percent of steady-state inflow because of increased precipitation during 2000, but simulated inflow is still only about 50 percent of conceptual inflow. Total recharge from irrigation is similar to recharge from irrigation for the steadystate period, but the distribution is different. The flow in Coal Creek in 2000 was 17,400 acre-ft, about 7,100 acre$\mathrm{ft} / \mathrm{yr}$ less than during the steady-state period (1938-49). This decreased flow results in less recharge from Coal Creek (parameter coalseep, fig. 29) and North Field and Union Ditch areas (parameter coalirr1, fig. 29). Irrigation and municipal ground-water withdrawal in 2000, however, was 34,200 acre-ft, about 20,900 acre-ft/yr more than during the steady-state period. Some of this withdrawal contributes to ground-water recharge and causes recharge to be more than steady-state recharge in the area of low-priority water rights (parameter coalirr2, fig. 29) and the areas irrigated only by ground water (parameter wellirr, fig. 29).

Table 15. Conceptual ground-water budget for 2000 and ground-water budget simulated in stress period 63 of the transient groundwater flow model, Cedar Valley, Iron County, Utah

[Conceptual flow as shown in table 2 may differ because method of calculating recharge changed during model calibration. Some well discharge reported in table 2 occurs outside the simulated area]

\begin{tabular}{|c|c|c|c|c|c|}
\hline \multirow[b]{2}{*}{ Budget component } & \multicolumn{2}{|c|}{ Conceptual flow } & \multirow[b]{2}{*}{ Method of simulation } & \multicolumn{2}{|c|}{ Simulated flow } \\
\hline & $\begin{array}{l}\text { (acre-feet } \\
\text { per year) }\end{array}$ & $\begin{array}{c}\text { (cubic feet } \\
\text { per day, rounded) }\end{array}$ & & $\begin{array}{l}\text { (acre-feet } \\
\text { per year) }\end{array}$ & $\begin{array}{c}\text { (cubic feet } \\
\text { per day, rounded) }\end{array}$ \\
\hline \multicolumn{6}{|c|}{ Recharge } \\
\hline $\begin{array}{l}\text { Irrigation and precipitation on } \\
\text { irrigated lands, including } \\
\text { seepage from Coal Creek }\end{array}$ & 23,200 & $2,760,000$ & Areal recharge in Recharge Package & 19,500 & $2,330,000$ \\
\hline Winter precipitation on all areas & 6,300 & 750,000 & Areal recharge in Recharge Package & 5,900 & 700,000 \\
\hline Parowan Valley ${ }^{1}$ & 5,400 & 640,000 & Specified flux in Well Package & 3,100 & 370,000 \\
\hline North consolidated rock & 4,300 & 510,000 & Specified flux in Well Package & 1,400 & 160,000 \\
\hline Southeast consolidated rock & 3,400 & 400,000 & Specified flux in Well Package & 300 & 36,000 \\
\hline East consolidated rock & 700 & 84,000 & Specified flux in Well Package & 700 & 84,000 \\
\hline Southwest consolidated rock & 1,500 & 180,000 & Specified flux in Well Package & 1,600 & 190,000 \\
\hline West consolidated rock & 1,000 & 120,000 & Specified flux in Well Package & 1,000 & 120,000 \\
\hline Inflow from south of area & 0 & 0 & $\begin{array}{l}\text { Head-dependent flux in General-Head } \\
\text { Boundary Package }\end{array}$ & 80 & 9,500 \\
\hline Total (rounded) & 46,000 & $5,400,000$ & & 33,600 & $4,000,000$ \\
\hline \multicolumn{6}{|c|}{ Discharge } \\
\hline Evapotranspiration & 3,000 & 480,000 & $\begin{array}{l}\text { Head-dependent flux in } \\
\text { Evapotranspiration Package }\end{array}$ & 4,500 & 530,000 \\
\hline Wells & 34,200 & $4,100,000$ & Specified flux in Well Package & 34,200 & $4,080,000$ \\
\hline Springs & 0 & 0 & Head-dependent flux in Drain Package & 1,300 & 150,000 \\
\hline Outflow to other areas & 1,000 & 240,000 & $\begin{array}{l}\text { Head-dependent flux in General-Head } \\
\text { Boundary Package }\end{array}$ & 2,700 & 320,000 \\
\hline Total (rounded) & 38,000 & $4,800,000$ & & 42,700 & $5,100,000$ \\
\hline To storage & ${ }^{2} 7,000$ & 600,000 & From storage & 9,100 & $1,100,000$ \\
\hline
\end{tabular}


Simulated discharge is 6 percent more than conceptual discharge, with the main difference being discharge to springs. The transient simulation does not accurately represent the decrease in spring flow near Enoch that occurred with increasing ground-water withdrawal. Adjustments to try to decrease the spring flow negatively affected simulated water levels. Simulated discharge to wells, evapotranspiration, and outflow to other areas is similar to conceptual discharge.

The main difference between the simulated and conceptual budgets is that recharge in the conceptual budget exceeds discharge and water is taken into storage, but discharge in the simulated budget exceeds recharge and water is released from storage. The simulated decrease in storage more closely matches the measured water-level declines from March 2000 to March 2001 than does the conceptual increase in storage.

\section{Parameter Correlation, Sensitivity Analysis, and Need for Additional Data}

The hydraulic properties simulated in this model are reasonable approximations of the actual hydraulic properties on the basis of available data. In the steadystate simulation, no parameters are highly correlated; the highest correlation coefficient is 0.92 between two hydraulic-conductivity parameters. Numerical instability relating to layer 1 becoming dry and layer 2 becoming unconfined prevented sensitivity analysis and determination of parameter correlation for the transient simulation. In general, the parameters are considered to be independent of each other. For instance, it is not likely that increasing both recharge and hydraulic conductivity would cause simulated water levels to be similar to water levels simulated by this model. It is possible, however, that other combinations of recharge, discharge, and aquifer properties may yield a similar or improved match to measured water levels. Flow measurements (such as discharge to streams or springs) are typically more useful than water-level measurements in trying to obtain a unique simulation, but in Cedar Valley, this discharge does not occur. Better estimates of evapotranspiration from ground water cannot be used directly to reduce parameter correlation, but could be useful in reducing the uncertainty in the ground-water budget. The conceptual rate of ground-water withdrawal is considered to be accurate and was not varied in the model. The final values of all model parameters are based on that withdrawal rate. Calibrating to a different rate or distribution of ground-water withdrawal could change the final values of the calibration parameters.
During model development and calibration, changes were made to the ground-water budget and aquifer characteristics in response to available information. Examples of this are changes in irrigation to better match water levels, and changes in vertical anisotropy to better match water levels in an area that was not stressed during steady-state calibration. Similarly, this model should not be considered static. Hydraulic properties in the northern part of the modeled area are based on few water-level data. If water-level data become available, the model may need to be modified to match that data. Additional ground-water withdrawals may induce horizontal or vertical gradients that were not present during the calibration period and that may indicate different aquifer characteristics.

Simulated steady-state water levels respond more to location and amount of irrigation recharge than to any other model parameter as indicated by composite scaled sensitivity (fig. 34). If recharge is substantially different from that used in the construction of this model, then simulated aquifer characteristics and other model parameters may not be realistic estimates of actual hydrologic properties. The "Recharge from irrigation" section of this report details the assumptions made during model construction and calibration. Measurements of distribution through canals, amount of water applied in city and residential areas, and amount of runoff in irrigated, city, and residential areas would refine the conceptual understanding of the ground-water system and may improve model fit.

An analysis of sensitivity maps indicated that several observation wells used in this model are located in areas most sensitive to certain parameters (table 16). For several parameters, however, water-level observations are not available in areas most sensitive to the parameter. The locations of available water-level observations from March 1939 to 2001 and other locations with the highest one-percent scaled sensitivity in layer 2 to selected model parameters in the steady-state simulation are shown in figure 40 . The sensitivity maps were created by using one-percent scaled sensitivities determined for each model grid. One-percent sensitivity indicates the amount an observation changes for a one-percent change in model parameter.

Water-level data collected at sites where data were not available during the calibration period may help refine the model and the conceptual understanding of the ground-water system. Water-level data collected in the future at the sites used during this study may indicate changes occurring in the ground-water system. Longterm water-level fluctuations at new sites would be needed to refine estimates of specific yield, specific 
Table 16. Observations with the highest one-percent scaled sensitivity in layer 2 to selected model parameters simulated in the steady-state ground-water flow model, Cedar Valley, Iron County, Utah

[Observations starting with "Obs" were not available during the calibration period; parameters with absolute one-percent scaled sensitivity less than 0.10 not listed]

\begin{tabular}{|c|c|c|}
\hline $\begin{array}{l}\text { Model parameter } \\
\text { (fig. 34) }\end{array}$ & $\begin{array}{l}\text { Observations most } \\
\text { sensitive to parameter in } \\
\text { model layer }{ }^{1} 2 \\
\text { (fig. 38) }\end{array}$ & $\begin{array}{l}\text { Approximate change } \\
\text { in simulated water } \\
\text { level, in feet, for a one- } \\
\text { percent increase in } \\
\text { parameter }\end{array}$ \\
\hline \multirow[t]{4}{*}{ hkedge } & Obs2 & -0.82 \\
\hline & (C-36-11)11bac-1 & -.61 \\
\hline & (C-36-11)3bda-1 & -.32 \\
\hline & Obs 1 & .12 \\
\hline \multirow[t]{2}{*}{ hkmid } & Obs3 & -1.10 \\
\hline & (C-35-12)26bca-1 & .13 \\
\hline \multirow[t]{2}{*}{ coalirr1 } & (C-36-11)11bac-1 & .44 \\
\hline & (C-35-11)27aca-1 & .42 \\
\hline \multirow[t]{2}{*}{ coalirr2 } & (C-36-11)8cbb-1 & .33 \\
\hline & (C-36-11)8dab-1 & .28 \\
\hline \multirow[t]{3}{*}{ coalseep } & Obs2 & .91 \\
\hline & (C-36-11)11bac-1 & .68 \\
\hline & (C-36-11)3bda-1 & .46 \\
\hline \multirow[t]{4}{*}{ precip } & Obs3 & .54 \\
\hline & (C-36-11)31daa-1 & .13 \\
\hline & (C-36-11)31daa-2 & .13 \\
\hline & (C-33-10)31cab-1 & .11 \\
\hline et & $(\mathrm{C}-34-10) 6 \mathrm{ccc}-1$ & -.10 \\
\hline bedrockno & Obs3 & .76 \\
\hline bedrockwes & Obs5 & .20 \\
\hline \multirow[t]{3}{*}{ bedrocksw } & Obs6 & .24 \\
\hline & $(\mathrm{C}-37-12) 5 \mathrm{bcb}-1$ & .17 \\
\hline & (C-37-12)5aad-3 & .12 \\
\hline \multirow[t]{3}{*}{ bedrockse } & Obs4 & .15 \\
\hline & (C-36-11)31daa-2 & .12 \\
\hline & (C-36-11)31daa-1 & .11 \\
\hline parowan & Obs7 & .49 \\
\hline sprenoch & Obs8 & -.18 \\
\hline \multirow[t]{4}{*}{ ghb } & Obs1 & -.16 \\
\hline & (C-35-12)27bbd-1 & .14 \\
\hline & (C-35-12)27bca-1 & .13 \\
\hline & $(\mathrm{C}-35-12) 27 \mathrm{bcc}-1$ & .13 \\
\hline \multirow[t]{3}{*}{ hk3 } & Obs4 & -.48 \\
\hline & (C-36-11)31daa-2 & -.38 \\
\hline & (C-36-11)31daa-1 & -.37 \\
\hline hk4 & Obs9 & -.10 \\
\hline hk5 & (C-35-12)26bca-1 & -.11 \\
\hline
\end{tabular}

storage, and probably horizontal-to-vertical anisotropy. Although sensitivity analysis does not indicate a high sensitivity to anisotropy (fig. 34), simulated water levels near some pumping wells did not decrease as much as observed water levels until the value of horizontal-tovertical anisotropy was increased. This change inhibited water in layer 1 from supplying pumping wells in layers 2 and 3 and caused simulated water levels in layers 2 and 3 to decrease more throughout a larger area, similar to observed levels. Aquifer tests designed to determine vertical conductance may help refine the model in those areas.

\section{Model Projections}

The ground-water flow model was used to estimate possible effects on water levels caused by increased withdrawal from wells, less-than-normal precipitation and streamflow, and changing water use from irrigation to municipal supply. The first projection simulated average streamflow during 1939-2000, average precipitation (1961-90) and 2000 ground-water withdrawal rates. This was used as a baseline to estimate water-level changes if current ground-water withdrawals continue. The surfacewater irrigation distribution, recharge from consolidated rock and Parowan Valley, and recharge from winter precipitation was the same as for the steady-state simulation, which had conditions very similar to long-term average. The ground-water irrigation distribution was the same as for stress period 63 in the transient simulation. Simulated ground-water budgets for the steady-state simulation, stress period 63 of the transient simulation, and projected 30-year simulations are listed in table 17.

During some projection simulations, layer 1 became dry in some areas. Well withdrawal from layer 1 was moved to layer 2 in these areas to keep the withdrawal rate constant throughout the simulation period. This assumed that all wells that were completed in layer 1 were also completed in layer 2 . Inflow from consolidated rock was the same as for the steady-state simulation. During some projection simulations, layer 2 along the west edge near Quichapa Lake became dry in a few cells, and the cells representing inflow from consolidated rock were moved away from the edge to keep them active.

The following projections assume the same distribution of ground-water withdrawal as for 2000 in stress period 63 of the transient simulation. The effects of locating wells in new areas are not projected. The following projections also assume the same distribution of irrigated lands and municipal areas as simulated for 2000 in stress 


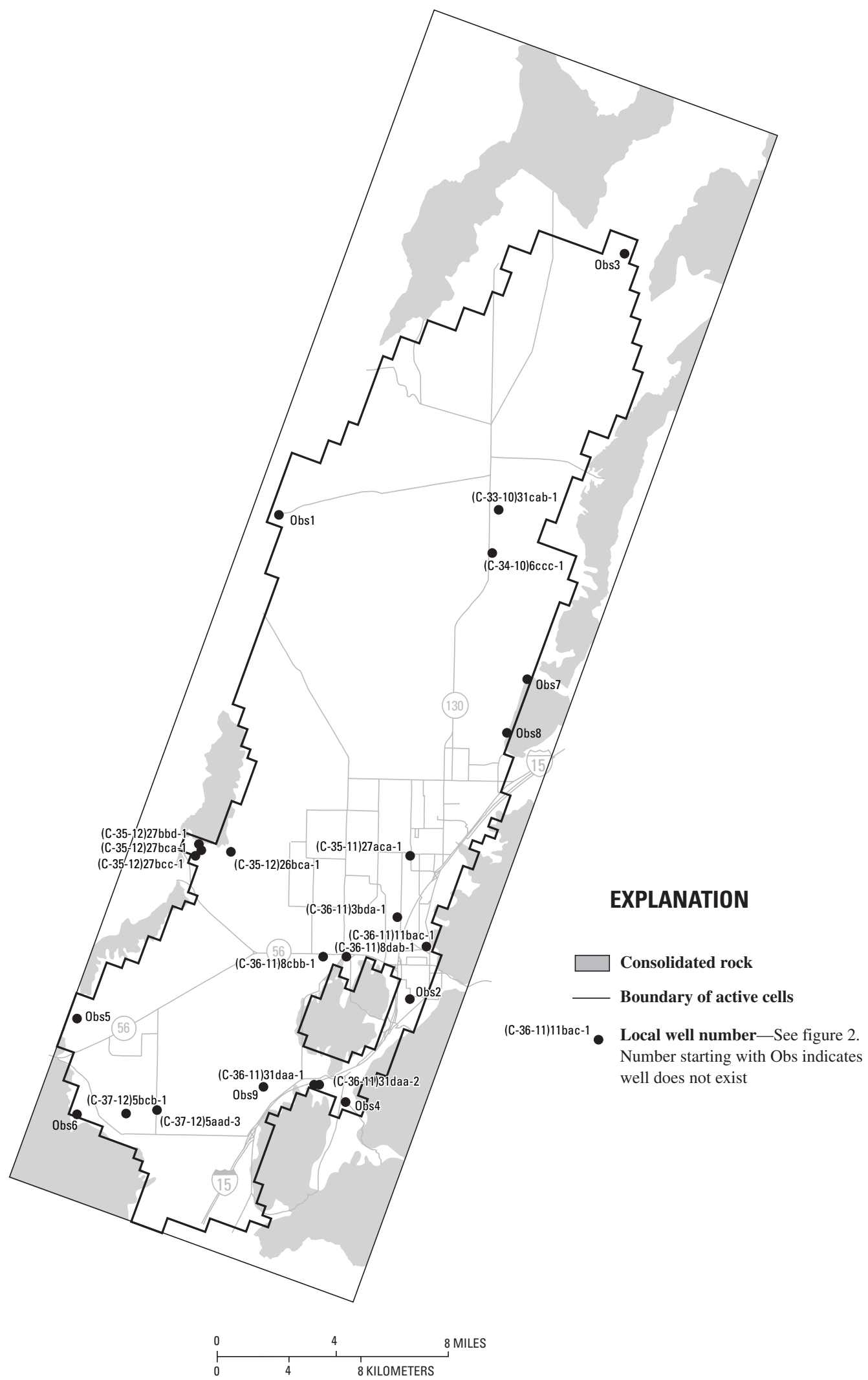

Figure 40. Location of simulated water levels with highest one-percent scaled sensitivity in layer 2 to selected model parameters simulated in the steadystate ground-water flow model, Cedar Valley, Iron County, Utah. 
Table 17. Ground-water budget for the steady-state simulation, stress period 63 of the transient simulation, and projected 30 -year simulations, Cedar Valley, Iron County, Utah

[All flows in acre-feet per year; stress period 63 corresponds with March 2000 to February 2001]

\begin{tabular}{|c|c|c|c|c|c|c|c|c|}
\hline Budget component & $\begin{array}{c}\text { Steady-state } \\
\text { simulation }\end{array}$ & $\begin{array}{c}\text { Transient } \\
\text { simulation, } \\
\text { stress period } \\
63\end{array}$ & Projection 1 & Projection 2 & Projection 3 & $\begin{array}{c}\text { Projection } 4 \\
\text { stress period } \\
20\end{array}$ & Projection 5 & Projection 6 \\
\hline \multicolumn{9}{|c|}{ Recharge } \\
\hline $\begin{array}{l}\text { Irrigation and precipitation } \\
\text { on irrigated lands, } \\
\text { including seepage from } \\
\text { Coal Creek }\end{array}$ & 19,100 & 19,500 & 24,300 & 28,600 & 32,900 & 14,900 & 21,600 & 25,800 \\
\hline $\begin{array}{l}\text { Winter precipitation on all } \\
\text { areas }\end{array}$ & 5,900 & 5,900 & 5,900 & 5,900 & 5,900 & 3,000 & 5,900 & 5,900 \\
\hline $\begin{array}{l}\text { Inflow from consolidated } \\
\text { rock and Parowan Valley }\end{array}$ & 6,600 & 8,100 & 6,600 & 6,600 & 6,600 & 3,100 & 6,600 & 6,600 \\
\hline Inflow from south of area ${ }^{1}$ & 0 & 80 & 800 & 1,200 & 1,700 & 1,400 & 1,000 & 1,600 \\
\hline Total & 31,600 & 33,600 & 37,600 & 42,300 & 47,100 & 22,400 & 35,100 & 39,900 \\
\hline \multicolumn{9}{|c|}{ Discharge } \\
\hline Evapotranspiration $^{\Gamma}$ & 13,100 & 4,500 & 2,800 & 2,500 & 2,300 & 1,700 & 3,800 & 3,100 \\
\hline Wells & 13,300 & 34,200 & 34,200 & 42,700 & 51,300 & 42,700 & 31,500 & 41,500 \\
\hline Springs ${ }^{1}$ & 1,700 & 1,300 & 1,000 & 800 & 500 & 0 & 900 & 600 \\
\hline Outflow to other areas ${ }^{1}$ & 3,500 & 2,700 & 2,400 & 2,200 & 2,000 & 2,100 & 2,400 & 2,200 \\
\hline Total & 31,600 & 42,700 & 40,400 & 48,200 & 56,100 & 46,500 & 38,600 & 47,400 \\
\hline $\begin{array}{l}\text { Water coming out of } \\
\text { storage }^{1}\end{array}$ & 0 & 9,100 & 2,800 & 5,900 & 9,000 & 24,100 & 3,500 & 7,500 \\
\hline $\begin{array}{l}\text { Total water out of storage } \\
\text { during simulation, in } \\
\text { acre-feet, rounded }\end{array}$ & 0 & ${ }^{2} 113,000$ & 110,000 & 185,000 & 324,000 & 304,000 & 130,000 & 270,000 \\
\hline
\end{tabular}

period 63 of the transient simulation. It is possible that if irrigation ground-water withdrawals increase, additional land will be irrigated. In that case, the simulations may overestimate actual recharge because water that is simulated as recharge may actually be consumptively used by the crops on the newly irrigated land. If additional land is irrigated with water from the wastewater treatment plant, simulated recharge, which is applied to the same area as in 2000 , also may be overestimated.

The second projection simulated average streamflow and precipitation conditions and ground-water withdrawal rates at 125 percent of 2000 withdrawal rates for all wells. Surface-water irrigation distribution, inflow from consolidated rock and Parowan Valley, and recharge from winter precipitation were the same as for the steadystate simulation. The distribution of ground water for irrigation was the same as for stress period 63 in the transient simulation, but all applied rates were 125 percent (an increase of 6,700 acre-ft/yr) of the rates simulated in stress period 63. Recharge from irrigation was increased in this simulation because of the increased ground water assumed to be applied to irrigated crops and municipal areas. Recharge from the area irrigated with discharge from the waste-water treatment plant also was increased in the simulation because it was assumed that discharge from the waste-water treatment plant was 125 percent of the 2000 discharge.

The third projection simulated average streamflow and precipitation conditions and ground-water withdrawal rates at 150 percent of 2000 withdrawal rates for all wells. Surface-water irrigation distribution, inflow from consolidated rock and Parowan Valley, and recharge from winter precipitation were the same as for the steadystate simulation. The distribution of ground water for irrigation was the same as for stress period 63 in the transient simulation, but all applied rates were 150 percent (an increase of 13,400 acre-ft/yr) of the rates simulated in stress period 63. Recharge from irrigation was increased in this simulation because of the increased ground water 


\section{Hydrology and Simulation of Ground-Water Flow in Cedar Valley, Iron County, Utah}

assumed to be applied to irrigated crops and municipal areas. Recharge from the area irrigated with discharge from the waste-water treatment plant was also increased in the simulation because it was assumed that discharge from the waste-water treatment plant was 150 percent of the 2000 discharge.

The fourth projection simulated a 10-year period of less-than-normal precipitation and streamflow for the middle 10 years of the 30 -year projection. During the first 10 years and last 10 years of the simulation, recharge and withdrawals were simulated as for the first projection. During the 10-year drier period, flow in Coal Creek was assumed to be 52 percent of mean annual flow with a flow of 12,600 acre-ft/yr. This flow rate and distribution of surface water for irrigation was used for some periods in the transient simulation. As a comparison to historic data, the lowest 10-year average for the period of record was 17,900 acre-ft/yr from 1954 to 1963 . During the projected 10-year drier period, withdrawal from wells was simulated as 125 percent of the 2000 withdrawal rate. Recharge from irrigation was determined by using the decreased flow in Coal Creek, 125 percent of the simulated amount of ground-water applied in 2000, and 50 percent of the normal precipitation. Although municipal well withdrawal and recharge was increased, discharge from the waste-water treatment plant was assumed to remain equal to the 2000 discharge; the extra water was assumed to be used for municipal irrigation. Recharge from irrigation with treated water was less than simulated in the transient model for 2000 because precipitation was less during the 10-year drier period. Recharge from winter precipitation in the drier period was 50 percent of the recharge simulated in the steady-state and transient simulations, and inflow from consolidated rock and Parowan Valley was 47 percent of inflow in the steadystate simulation. These lower recharge values and higher withdrawal values for the simulated drier period are listed in table 17 to compare with average values.

The fifth projection simulated average streamflow and precipitation conditions and a change in water use from irrigation to municipal supply. Withdrawal from irrigation wells was reduced by 25 percent, about 6,700 acre-ft/yr. A 40-percent reduction in water right accompanied the change, so municipal withdrawal was increased by 60 percent of this 6,700 acre-ft, or about $4,000 \mathrm{acre}-\mathrm{ft} / \mathrm{yr}$. The total municipal withdrawal of 11,400 acre- $\mathrm{ft} / \mathrm{yr}$ is about 155 percent of 2000 municipal withdrawal. Distribution of ground water for irrigation was assumed to be the same as in 2000, but the amount was reduced by 25 percent, which caused a reduction in recharge in crop areas irrigated with ground water.
Recharge from irrigation in municipal areas was 155 percent of recharge in 2000. Discharge from the waste-water treatment plant also was assumed to be 155 percent of the discharge in 2000 and recharge from irrigation with the discharge also was increased. Distribution of surface water for irrigation, inflow from consolidated rock and Parowan Valley, and recharge from winter precipitation were the same as for the steady-state simulation.

The sixth projection simulated average streamflow and precipitation conditions, municipal withdrawals of 200 percent of the 2000 withdrawal rates, and irrigation withdrawals the same as 2000 withdrawal rates. Distribution of surface water for irrigation, inflow from consolidated rock and Parowan Valley, and recharge from winter precipitation were the same as for the steady-state simulation. Distribution of ground water for irrigation was the same as for stress period 63 in the transient simulation, but recharge was doubled in the municipal areas. Discharge from the waste-water treatment plant also was assumed to be 200 percent of the discharge in 2000 and recharge from irrigation with the discharge also was increased.

\section{Results}

In the projection simulations, ground-water levels typically decline 20 to $100 \mathrm{ft}$ in the southern and central parts of the valley and less than $20 \mathrm{ft}$ in the northern part of the valley (figs. 41 to 46). The maximum projected drawdown of $275 \mathrm{ft}$ occurred west of Quichapa Lake because of simulated ground-water withdrawal for municipal use. Projection 6, with 200 percent of 2000 municipal ground-water withdrawal rate, has the greatest drawdown. Projection 3, with 150 percent of 2000 ground-water withdrawal rates, and projection 4 , with a 10-year drier-than-normal period, have greater drawdown over a larger area than other projections. Drawdown is the simulated change in water level from the beginning of the projection simulation to the end of the 30-year simulation. A negative drawdown indicates a water-level rise. The beginning water level is the water level simulated at the end of the transient simulation, not water levels measured in March 2001.

In some areas, water levels rise in the projection simulations. Simulated water levels rise near Coal Creek in projection 1 because flow and recharge from Coal Creek are higher than in the last stress period of the transient simulation and ground-water withdrawals do not occur in that area. Water levels also rise in the areas with decreased irrigation withdrawals in projection 5 and near 


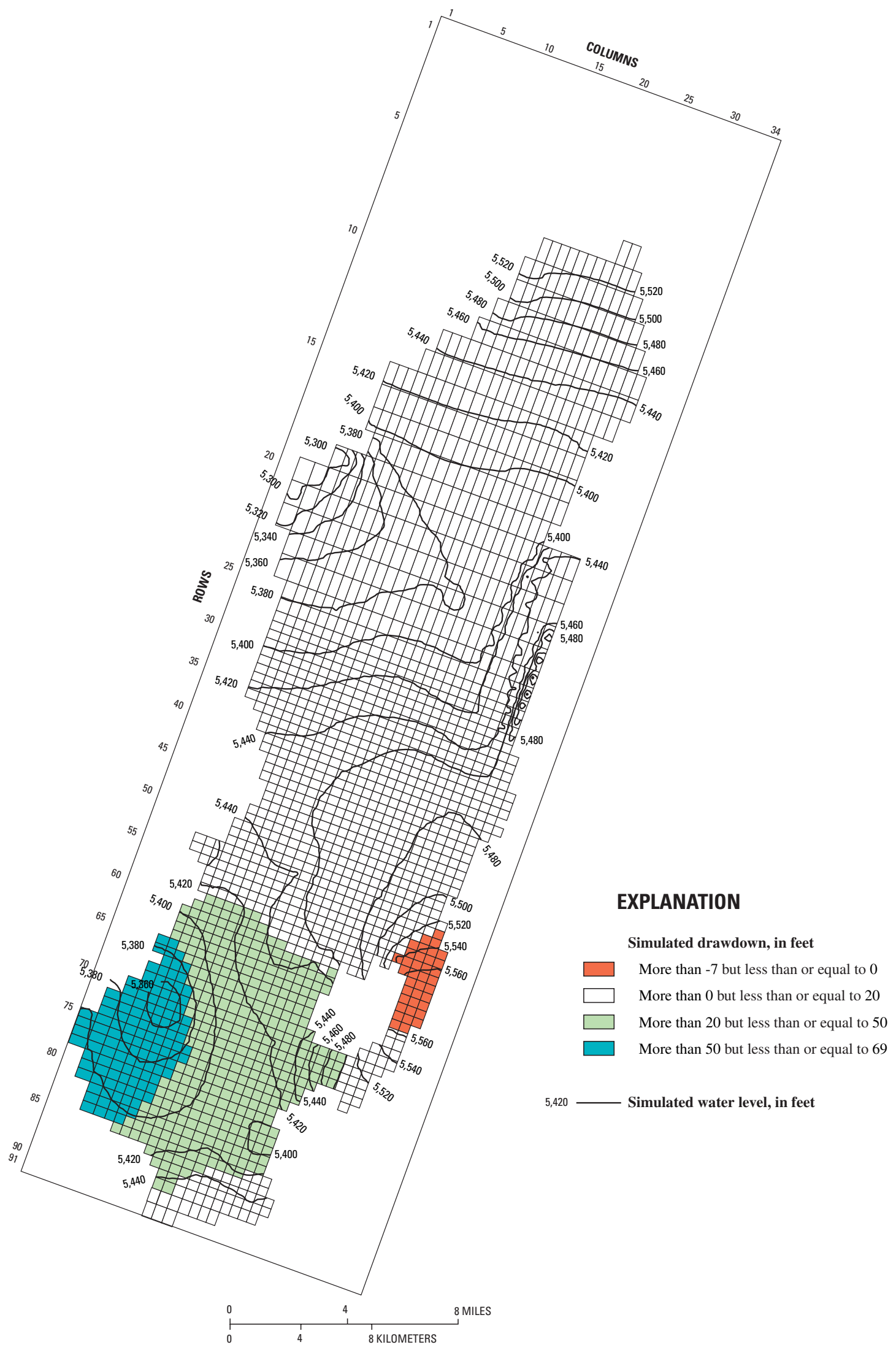

Figure 41. Drawdown and water level in model layer 2 at the end of 30-year simulation, projection 1 of the ground-water flow model, Cedar Valley, Iron County, Utah. 


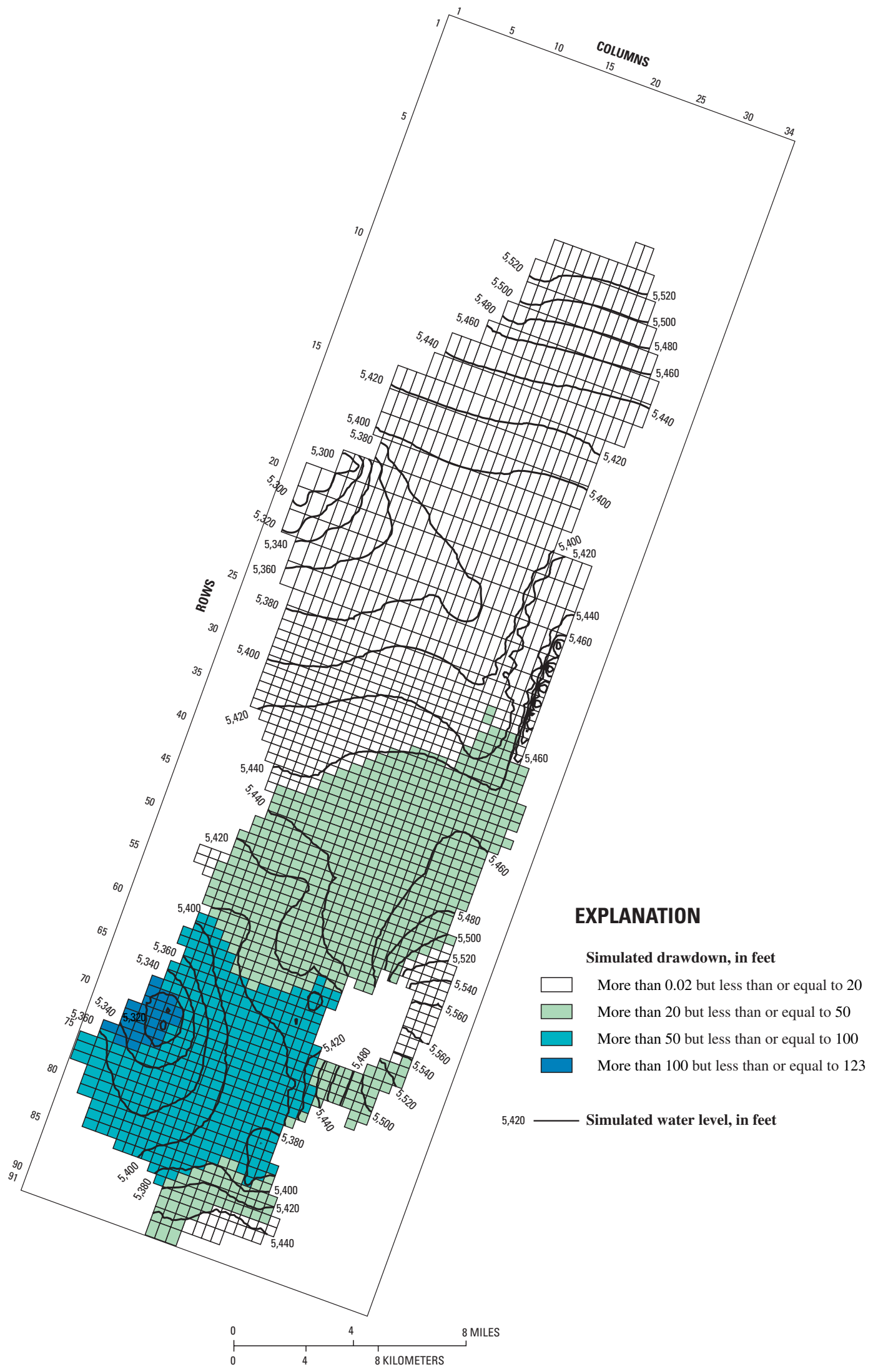

Figure 42. Drawdown and water level in model layer 2 at the end of 30-year simulation, projection 2 of the ground-water flow model, Cedar Valley, Iron County, Utah. 


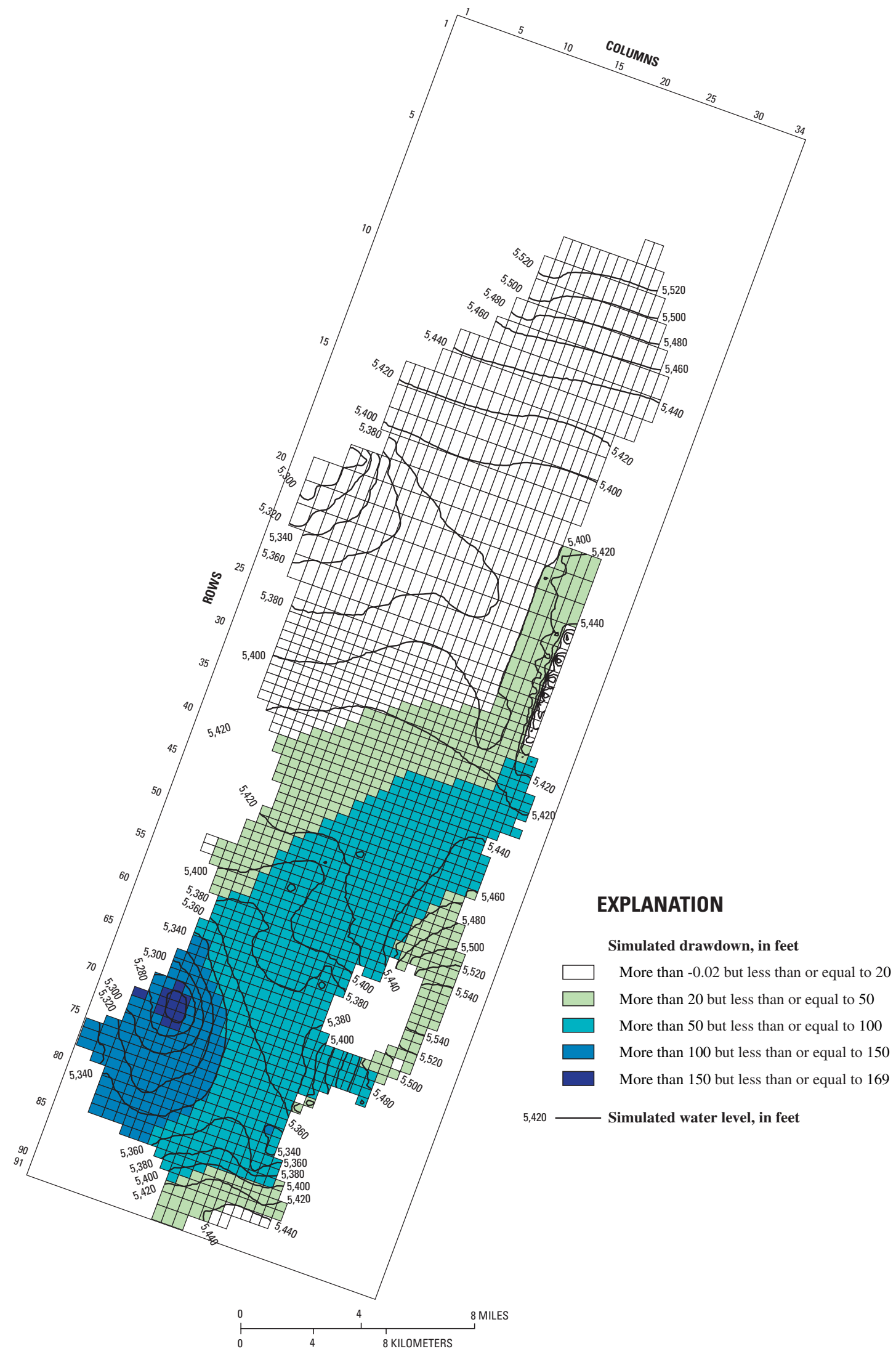

Figure 43. Drawdown and water level in model layer 2 at the end of 30-year simulation, projection 3 of the ground-water flow model, Cedar Valley, Iron County, Utah. 


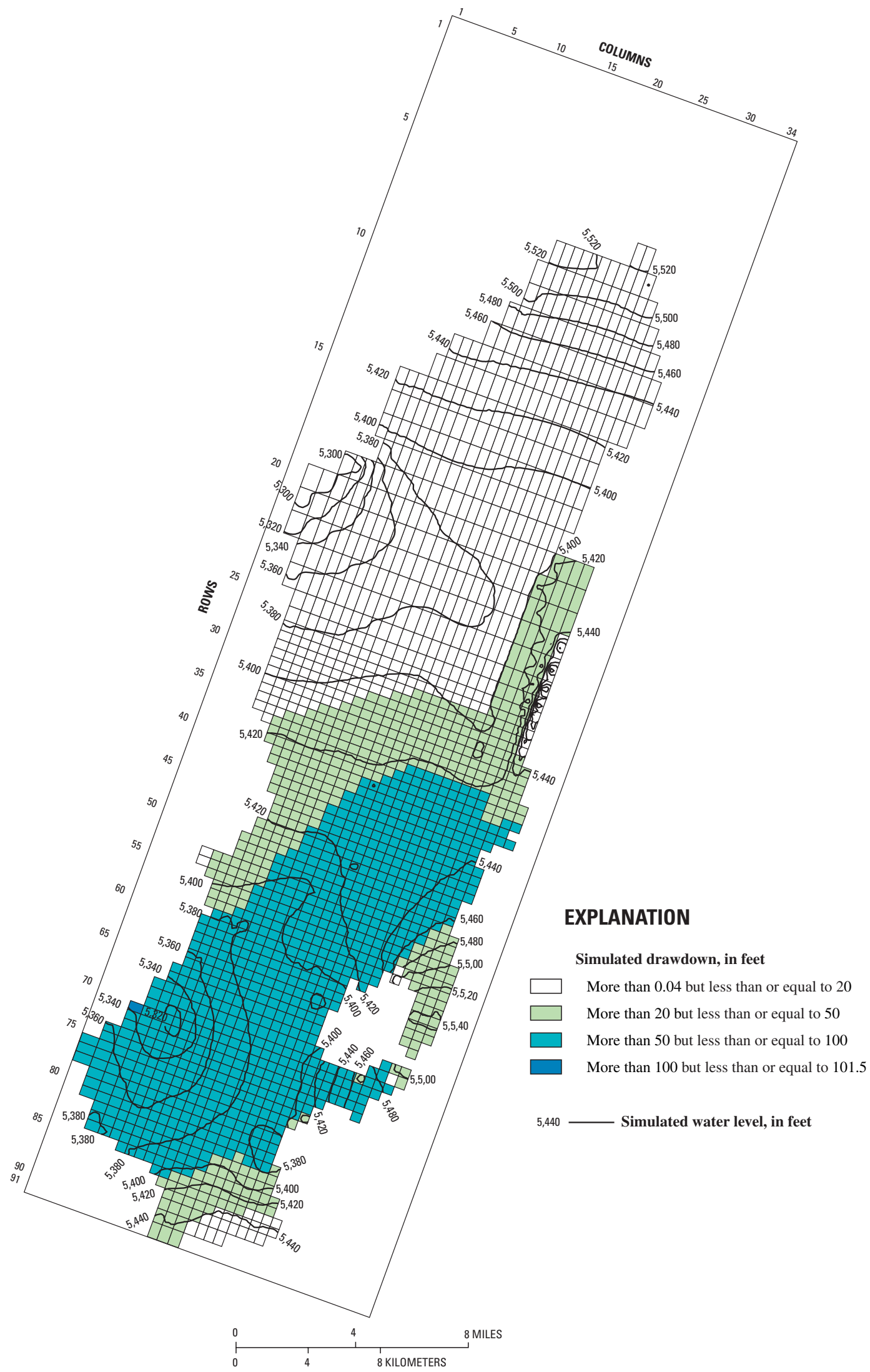

Figure 44. Drawdown and water level in model layer 2 at the end of 30-year simulation, projection 4 of the ground-water flow model, Cedar Valley, Iron County, Utah. 


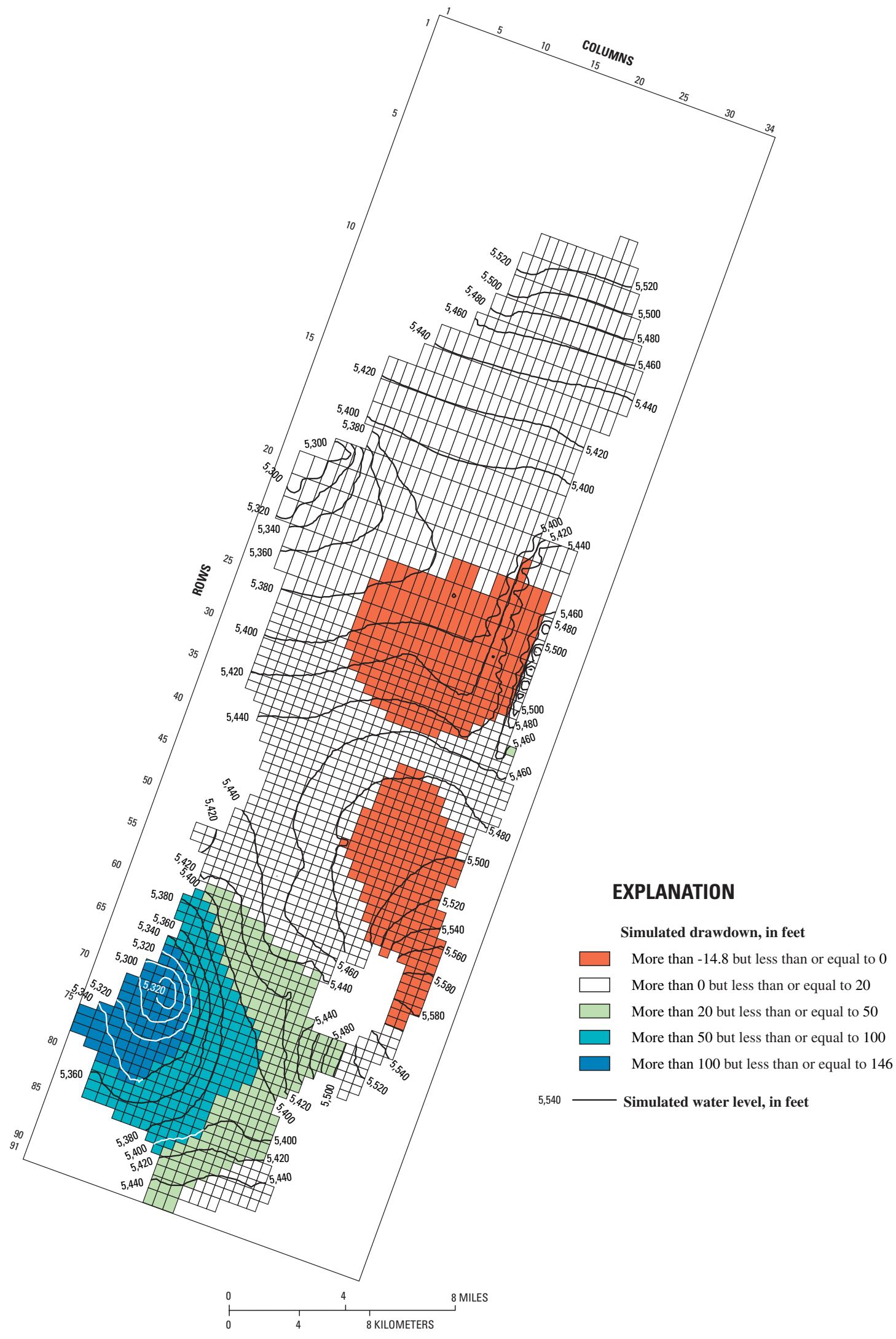

Figure 45. Drawdown and water level in model layer 2 at the end of 30-year simulation, projection 5 of the ground-water flow model, Cedar Valley, Iron County, Utah. 


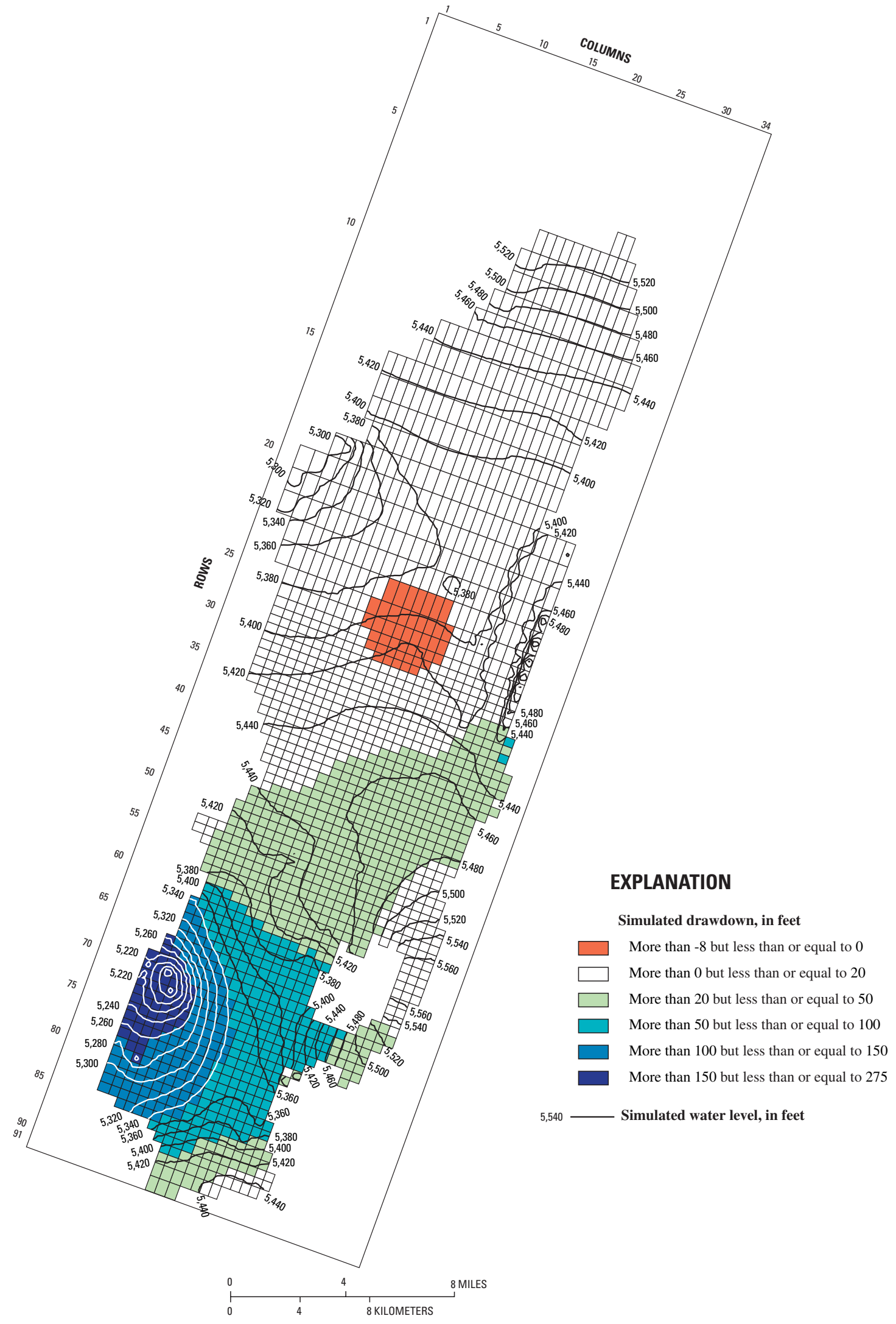

Figure 46. Drawdown and water level in model layer 2 at the end of 30-year simulation, projection 6 of the ground-water flow model, Cedar Valley, Iron County, Utah. 
the waste-water treatment plant in projection 6 because of increased recharge from the increased treatment plant discharge.

Simulated water levels at most of selected locations (fig. 47) continue to decline throughout the projection period (fig. 48). The continuous decline indicates that ground water is being removed from storage and that a new steady-state flow budget has not been established after 30 years. Simulated recharge cannot be increased enough, nor simulated discharge decreased enough, to meet the projected withdrawals. Natural discharge that can be decreased is evapotranspiration, outflow to other areas, and discharge to springs. Because most recharge is simulated as specified-flux boundaries, simulated recharge can only increase as inflow from south of the area. This affects local water levels only.

Using current or projected withdrawals, the model indicates that the amount of water in storage in the ground-water system during the 30 years of projection will decline as much as or more than from 1950 to 2000 (table 17). The decline from 1950 to 2000 is not known to have caused subsidence or changes in aquifer properties. It is not known how much storage could be decreased before subsidence may occur.

Water levels for projection 4 rise at some locations during simulation years 20 to 30 . Rises occur near natural discharge boundaries such as Location 2 near the springs near Enoch and Location 3 in an area of evapotranspiration. The simulated discharge to springs and evapotranspiration was greatly reduced or eliminated during the simulation of drier-than-normal years, and with the return of normal conditions, simulated levels will rise until discharge to springs and evapotranspiration is again equilibrated with recharge in those areas. Water levels also rise during simulation years 20 to 30 in projection 4 at the south end of the valley. Here, water-level declines during drier-than-normal conditions simulated in stress periods 10 to 20 have induced additional ground-water inflow from south of the area. This increased flow will continue until water levels rise enough to equilibrate with discharge in the area.

Some evapotranspiration from ground water continues throughout the simulation period in all projections, mostly in the area of simulated high horizontal-to-vertical anisotropy of hydraulic conductance northwest of Enoch and in the area around and west of Rush Lake. Ground-water withdrawal occurs mostly south of these areas. Outflow through Mud Springs Canyon continues throughout the simulation period in all projections; flow from the area north of Rush Lake out Mud Springs Canyon is not affected by any of the simulations. Most of the projections also indicate continued, although reduced, discharge to the springs near Enoch. As with the transient simulation, this is a known error in the model calibration. This error probably causes projected drawdown in the area to be less than what may actually occur. During all projection simulations, some increased ground-water withdrawal is supplied by decreasing the discharge to the springs. Because this discharge does not currently exist, all actual ground-water withdrawal must be met by decreasing storage and declining water levels.

Model projections should not be used to predict actual water levels at some future date, but can give general ideas about water-level declines likely to occur throughout the valley. The transient simulation underestimated water-level declines in the Enoch and Quichapa areas; it is likely the projection simulations also underestimate water-level declines in those areas. The more the projected stresses vary from stresses used during the calibration period, the more likely simulated water-level declines may not accurately represent actual water-level declines. The ground-water system could respond in ways that are not simulated in these projections. It is possible that decreasing water levels near the mountains would increase inflow from consolidated rock and Parowan Valley. This would probably be only a temporary increase until water levels in the consolidated rock equilibriated with water levels in the unconsolidated basin fill. The projections simulate increased flow into the valley through unconsolidated basin fill south of Kanarraville. It is not known if this water is available, or how much water could move through the unconsolidated basin fill in this area.

\section{Summary}

Cedar Valley, located in the eastern part of Iron County in southwestern Utah, is experiencing rapid population growth that needs a larger share of the available water resources. Water withdrawn from the unconsolidated basin fill is the source for public supply and also a major source for irrigation. Water managers are concerned about increasing demands on the water supply and need hydrologic information to develop a plan for efficiently using water resources and minimizing flow of water unsuitable for domestic use toward present and future public-supply sources. 


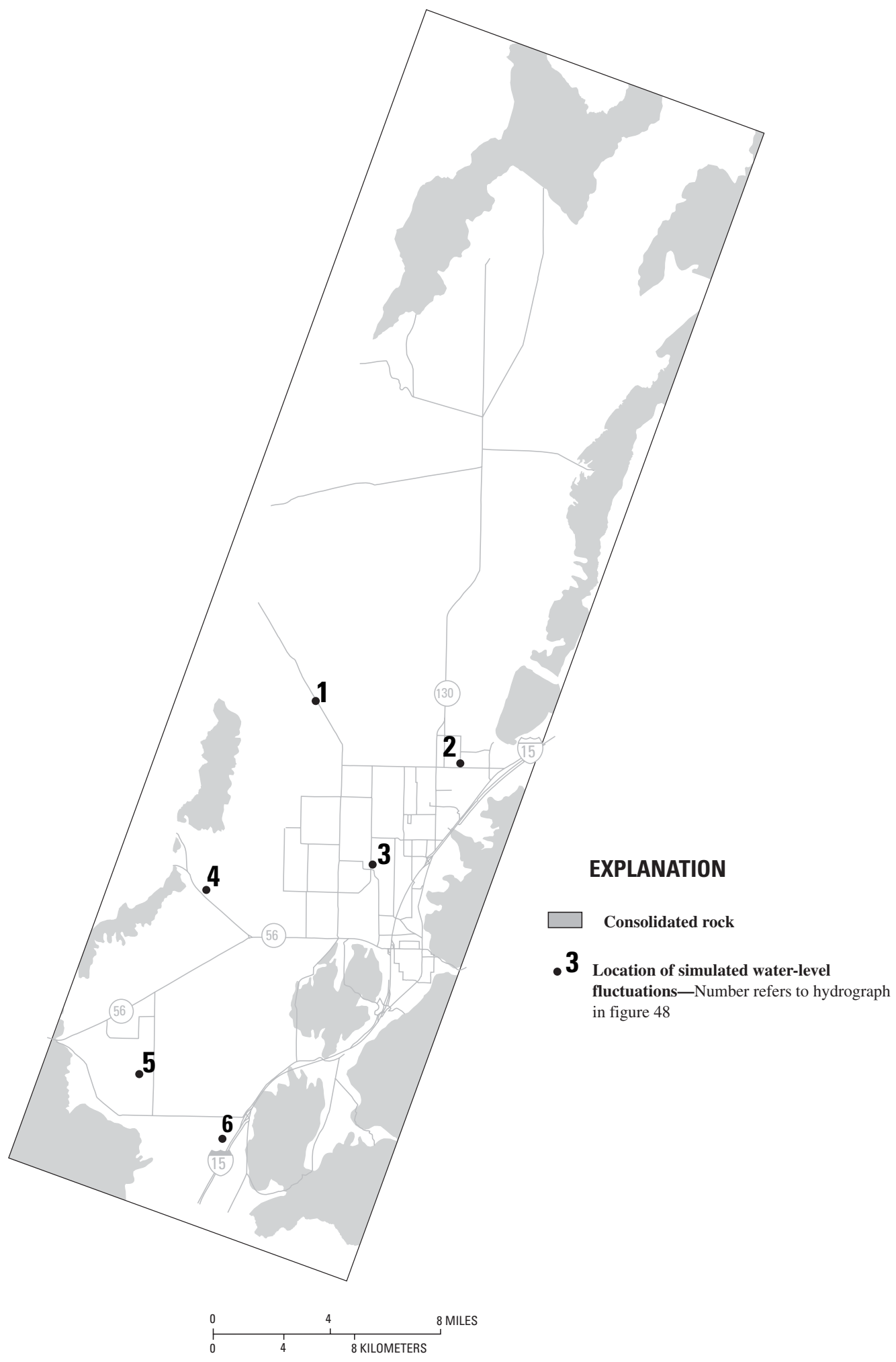

Figure 47. Location of selected simulated water-level fluctuations for model projections of the ground-water flow model, Cedar Valley, Iron County, Utah. 

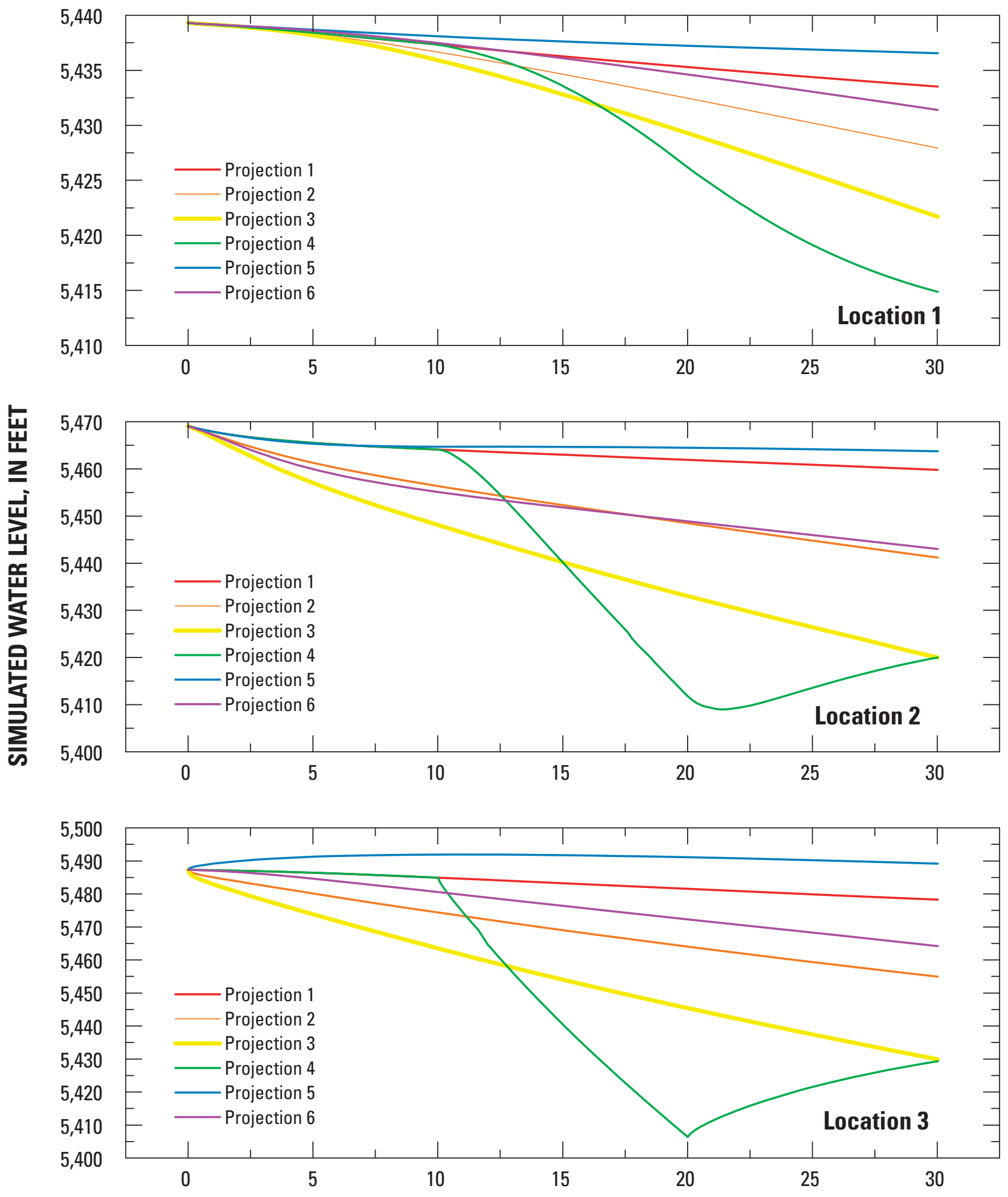

PROJECTED TIME, IN YEARS

Figure 48. Simulated water-level fluctuations for model projections of the ground-water flow model, Cedar Valley, Iron County, Utah. 

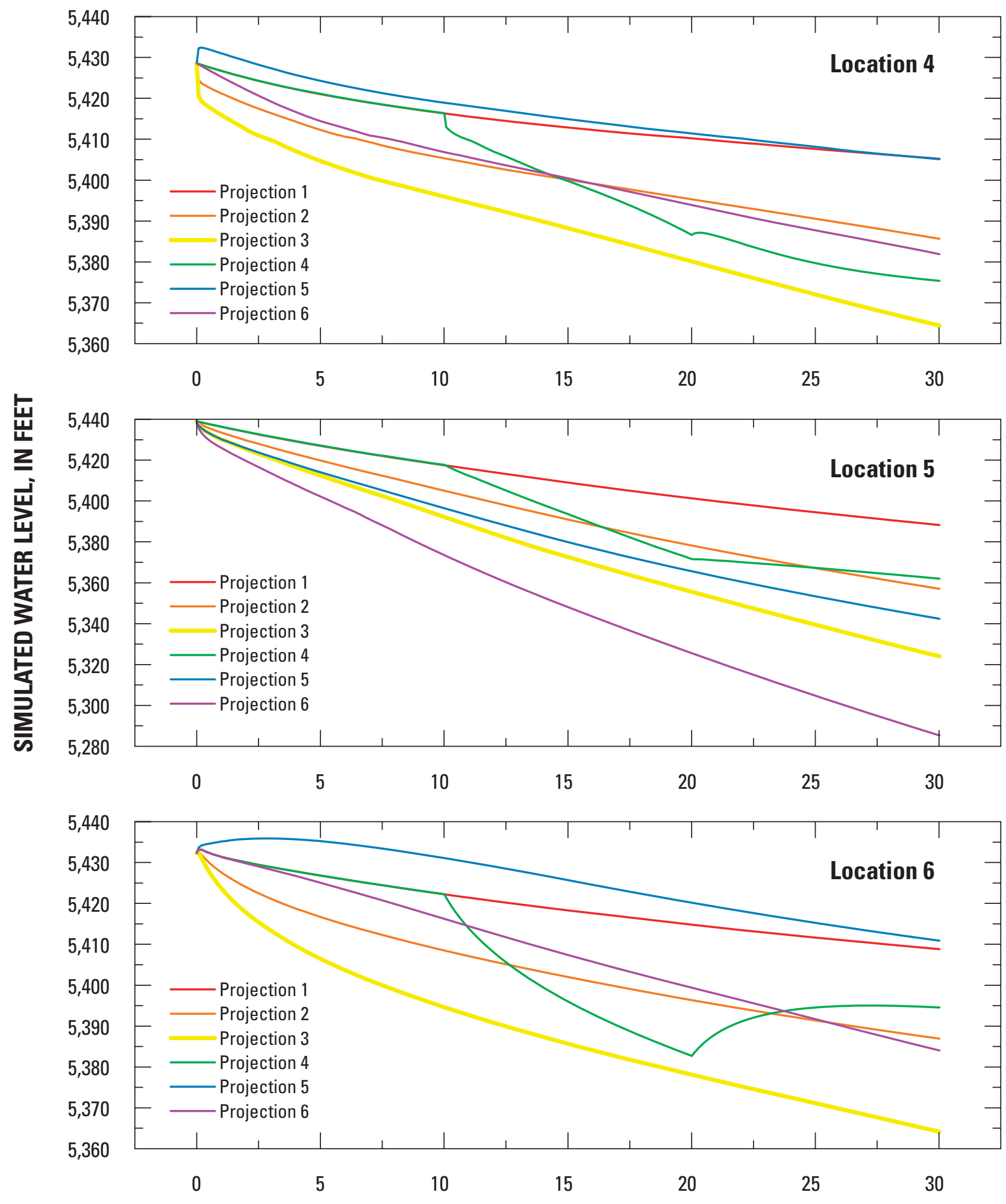

PROJECTED TIME, IN YEARS

Figure 48. Simulated water-level fluctuations for model projections of the ground-water flow model, Cedar Valley, Iron County, Utah—Continued. 
Cedar Valley is a structural depositional basin located at the transition between the Basin and Range and Colorado Plateau physiographic provinces. Snowmelt runoff from the Markagunt Plateau to the east provides much of the water to the largest stream, Coal Creek. The 1939-2000 average annual flow in Coal Creek is 24,200 acre-ft of which most of the high flow occurs during April through June. Water in Coal Creek is diverted into a complex distribution system for irrigation. No surface water exits the basin because all of it is consumed by plant consumptive use, evaporation, or seepage to the ground-water system.

The thickness of permeable unconsolidated basin fill is estimated to be more than 3,500 ft in the Rush Lake area and more than $1,000 \mathrm{ft}$ throughout most of the basin. Unconfined ground-water conditions exist along the basin margins and in the center of the basin above confining lenses. Confined conditions exist beneath discontinuous confining layers in the center of the basin. As water levels have declined as a result of continued groundwater withdrawals, the present extent of water under confined conditions may be less than previously defined. Ground water flows from the recharge areas near Coal Creek to three discharge areas at Rush Lake and Mud Springs Canyon, Iron Springs Gap, and Quichapa Lake.

Recharge to the unconsolidated basin fill is by seepage from unconsumed irrigation water, streams, and precipitation, and by subsurface inflow from consolidated rock and adjacent areas, and is estimated to be about 42,000 acre-ft/yr. The chloride mass-balance method indicates that recharge may be less than that, but is considered a rough approximation because of limited chloride concentration data for precipitation and Coal Creek. Stable-isotope data indicate that recharge sources are winter precipitation derived from snowmelt in upland areas or direct precipitation on unconsolidated basin fill. Continued declining water levels indicate that recharge is not sufficient to meet demand. Water levels in many areas are at or close to historic lows.

In 2000, ground-water withdrawal was estimated to be 36,000 acre-ft/yr. About 4,000 acre-ft/yr is estimated to discharge by evapotranspiration or as subsurface outflow. Prior to large-scale ground-water development, evapotranspiration is estimated to have been about 22,000 acre-ft/yr and is the largest component of discharge at that time. The large decline in evapotranspiration is a result of declining water levels, which are a result of increased withdrawals. As a result of declining water levels, most of the natural discharge has been intercepted by ground-water pumpage.
Water quality in Cedar Valley is mostly suitable for domestic use except along the eastern margin where water from some wells has elevated dissolved-solids and $\mathrm{NO}_{3}$ concentrations. Water with high dissolved-solids concentration generally has $\mathrm{Ca}$ and $\mathrm{SO}_{4}$ as the predominant ions, which are likely derived by the dissolution of gypsum in some of the Mesozoic-age rocks of the Markagunt Plateau. Ground water with low dissolved-solids concentration is located west of Quichapa Lake where less soluble Tertiary-age volcanic rocks compose the Harmony Mountains.

Nitrogen-15 and oxygen-18 isotopes in the nitrate anion were measured to determine possible $\mathrm{NO}_{3}$ sources and whether or not denitrification is occurring. No single source can be identified as the cause for elevated $\mathrm{NO}_{3}$ concentrations in ground water. Low $\delta^{15} \mathrm{~N}$ values north of Cedar City indicate a natural geologic source. Higher $\delta^{15} \mathrm{~N}$ values in water from wells that are located downgradient from areas where waste-water effluent has been discharged indicate possible recharge from the effluent. Excess dissolved $\mathrm{N}_{2}$ gas and low $\mathrm{NO}_{3}$ concentrations in shallow ground water at two locations indicate that denitrification is occurring. These data indicate that $\mathrm{NO}_{3}$ derived from near-surface sources might be reduced at these locations, but it is unknown whether this process is occurring in the shallow zones throughout the basin.

A computer ground-water flow model was developed to simulate flow in the unconsolidated basin fill in Cedar Valley to test the conceptual understanding of the ground-water system. This model was developed to simulate general ground-water flow through Cedar Valley and long-term water-level fluctuations; it was not developed to simulate local effects or cell-by-cell flow. In general, the model accurately simulates water levels and waterlevel fluctuations and can be considered an adequate tool to help determine the valley-wide effects on water levels of additional ground-water withdrawals and changes in water use.

The method of determining recharge from irrigation was changed during the calibration process to incorporate more areal and temporal variability. Simulated water levels respond more to location and amount of irrigation recharge than to any other model parameter. Measurements of distribution through canals, amount of water applied in city and residential areas, and amount of runoff in irrigated, city, and residential areas would refine the conceptual understanding of the ground-water system and may improve model fit. If recharge is substantially different from that used in the construction of this model, then simulated aquifer characteristics and other model parameters may not be realistic estimates of actual hydro- 
logic properties. Water-level data collected at sites where data were not available during the calibration period may help refine the model and the conceptual understanding of the ground-water system. Long-term water-level fluctuations at those sites would be needed to refine estimates of specific yield, specific storage, and probably horizontal-to-vertical anisotropy.

The ground-water flow model was used to predict possible effects on water levels caused by increased withdrawal from wells, less-than-normal precipitation and streamflow, and changing water use from irrigation to municipal supply. In the projection simulations, water levels in the southern part of the valley declined 20 to 275 $\mathrm{ft}$; the maximum projected drawdown of $275 \mathrm{ft}$ occurred west of Quichapa Lake during projection 6 because of increased simulated ground-water withdrawal for municipal use. The continuous decline in water levels for most projections indicates that ground water is being removed from storage and that a new steady-state equilibrium has not been established after 30 years. The simulated amount of water in storage in the ground-water system during the 30 years of projection declined as much or more than from 1950 to 2000. Model projections should not be used to predict actual water levels at some future date, but can give general ideas about water-level declines likely to occur throughout the valley. The more the projected stresses vary from stresses used during the calibration period, the more likely simulated water-level declines may not accurately represent actual water-level declines.

\section{References Cited}

Averitt, Paul, 1962, Geology and coal resources of the Cedar Mountain quadrangle, Iron County, Utah: U.S. Geological Survey Professional Paper 389, 72 p.

Averitt, Paul, 1967, Geologic map of the Kanarraville quadrangle, Iron County, Utah: U.S. Geological Survey Geologic Quadrangle Map GQ-694, scale 1:24,000.

Averitt, Paul, and Threet, R.L., 1973, Geologic map of the Cedar City quadrangle, Iron County, Utah: U.S. Geological Survey Geologic Quadrangle Map GQ-1120, scale 1:24,000.

Bjorklund, L.J., Sumsion, C.T., and Sandberg, G.W., 1977, Selected hydrologic data, Parowan and Cedar City drainage basins, Iron County, Utah: U.S. Geological Survey Open-File Report (unnumbered but duplicated as Utah Basic-Data Release No. 28), 55 p.

Bjorklund, L.J., Sumsion, C.T., and Sandberg, G.W., 1978, Ground-water resources of the Parowan-Cedar City drainage basin, Iron County, Utah: Utah Department of Natural Resources Technical Publication No. 60, 93 p.
Burden, C.B., and others, 2001, Ground-water conditions in Utah, spring of 2001: Utah Department of Natural Resources, Division of Water Resources, Cooperative Investigations Report No. 42, 120 p.

Burden, C.B., and others, 2002, Ground-water conditions in Utah, spring of 2002: Utah Department of Natural Resources, Division of Water Resources, Cooperative Investigations Report No. 43, 120 p.

Busenberg, Eurybiades, and Plummer, L.N., 1992, Use of chlorofluorocarbons $\left(\mathrm{CCl}_{3} \mathrm{~F}\right.$ and $\left.\mathrm{CCl}_{2} \mathrm{~F}_{2}\right)$ as hydrologic tracers and age-dating tools: the alluvium and terrace system of central Oklahoma: Water Resources Research, v. 28, no. 9, p. 2257-2283.

Christensen, R.C., Johnson, E.B., and Plantz, G.G., 1986, Manual for estimating selected streamflow characteristics of natural-flow streams in the Colorado River Basin in Utah: U.S. Geological Survey Water-Resources Investigations Report 85-4297, 39 p.

Clark, I.D., and Fritz, Peter, 1997, Environmental isotopes in hydrogeology: New York, Lewis Publishers, 328 p.

Coplen, T.B., 1993, Uses of environmental isotopes, in Alley, W.M., ed., Regional Ground-Water Quality: New York, Von Nostrand Reinhold, p. 227-254.

Coplen, T.B., Herczeg, A.L., and Barnes, Chris, 2000, Isotope engineering-Using stable isotopes of the water molecule to solve practical problems, in Cook, P.G., and Herczeg, A.L., eds., Environmental Tracers in Subsurface Hydrology: Boston, Kluwer Academic Publishers, p. 79-110.

Coplen, T.B., Wildman, J.D., and Chen, J., 1991, Improvements in the gaseous hydrogen-water equilibrium technique for hydrogen isotope ratio analysis: Analytical Chemistry, v. 63, p. 910-912.

Craig, Harmon, 1961, Standard for reporting concentrations of deuterium and oxygen-18 in natural water: Science, v. 133, p. $1702-1703$.

Dansgaard, W., 1964, Stable isotopes in precipitation: Talus, v. 16 , p. 436-468.

Davis, S.N., Whittemore, D.O., and Fabryka-Martin, June, 1998, Uses of chloride/bromide ratios in studies of potable water: Ground Water, v. 36, no. 2, p. 338-350.

Domenico, P.A., and Schwartz, F.O., 1990, Physical and chemical hydrogeology: New York, John Wiley and Sons, 824 p.

Epstein, Samuel, and Mayeda, T.K., 1953, Variation of O-18 content of water from natural sources: Geochemica et Cosmochimica Acta, v. 4, p. 213-224.

Fenneman, N.M., 1931, Physiography of the Western United States: New York, McGraw-Hill, 534 p.

Hallberg, G.R., and Keeney, D.R., 1993, Nitrate, in Alley, W.M., ed., Regional Ground-Water Quality: New York, Van Nostrand Reinhold, 634 p.

Harbaugh, A.W., Banta, E.R., Hill, M.C., and McDonald, M.G., 2000, MODFLOW-2000, The U.S. Geological Survey modular ground-water model-User guide to modularization concepts and the ground-water flow process: U.S. Geological Survey Open-File Report 00-92, 121 p. 
Harrill, J.R., and Prudic, D.E., 1998, Aquifer systems in the Great Basin region of Nevada, Utah, and adjacent states-Summary report: U.S. Geological Survey Professional Paper 1409-A, 66 p.

Heilweil, V.M., Freethey, G.W., Stolp, B.J., Wilkowske, C.D., and Wilberg, D.E., 2000, Geohydrology and numerical simulation of ground-water flow in the central Virgin River basin of Iron and Washington Counties, Utah: Utah Department of Natural Resources Technical Publication No. 116,139 p.

Hem, J.D., 1985, Study and interpretation of the chemical characteristics of natural water: U.S. Geological Survey WaterSupply Paper 2254, 263 p.

Herbert, L.R., Allen, D.V., Wilberg, D.E., and Tibbetts, J.R., 2000, Water resources data, Utah, water year 1999: U.S. Geological Survey Water-Data Report UT-99-1, 340 p.

Herbert, L.R., Wilberg, D.E., Tibbetts, J.R., and Allen, D.V., 2001, Water resources data, Utah, water year 2000: U.S. Geological Survey Water-Data Report UT-00-1, 380 p.

Herczeg, A.L., and Edmunds, W.M., 2000, Inorganic ions as tracers, in Cook, P.G., and Herczeg, A.L., eds., Environmental Tracers in Subsurface Hydrology: Boston, Kluwer Academic Publishers, p. 31-77.

Hevesi, J.A., Flint, A.L., and Flint, L.E., 2002, Preliminary estimates of spatially distributed net infiltration and recharge for the Death Valley region, Nevada-California: U.S. Geological Survey Water-Resources Investigations Report 02-4010, 36 p.

Hill, M.C., Banta, E.R., Harbaugh, A.W., and Anderman, E.R., 2000, MODFLOW-2000, The U.S. Geological Survey modular ground-water model-User guide to the observation, sensitivity, and parameter-estimation processes and three post-processing programs: U.S. Geological Survey Open-File Report 00-184, 209 p.

Howells, J.H., Mason, J.L., and Slaugh, B.A., 2002, Selected hydrologic data for Cedar Valley, and adjacent areas, Iron County, Utah, 1930-2001: U.S. Geological Survey OpenFile Report 01-419, 81 p.

Hurlow, H.A., 2002, The geology of Cedar Valley, Iron County, Utah, and its relation to ground-water conditions: Utah Geological Survey Special Study 103, 74 p.

Kendall, Carol, 1998, Tracing nitrogen sources in Catchments, in Kendall, Carol, and McDonnell, J.J., eds., Isotope tracers in catchment hydrology: New York, Elsevier, p. 519-576.

Kendall, Carol, and Aravena, Ramon, 2000, Nitrate isotopes in groundwater systems, in Cook, P.G., and Herczeg, A.L., eds., Environmental Tracers in Subsurface Hydrology: Boston, Kluwer Academic Publishers, p. 261-297.

Lohman, S.W., 1972, Ground-water hydraulics: U.S. Geological Survey Professional Paper 708, 70 p.

Lowe, Mike, and Wallace, Janae, 2001, Evaluation of potential geologic sources of nitrate contamination in ground water, Cedar Valley, Iron County, Utah, with emphasis on the Enoch area: Utah Geological Survey Special Study 100, 50 p.
Mackin, J.H., Nelson, W.H., and Rowley, P.D., 1976, Geologic map of the Cedar City NW quadrangle, Iron County, Utah: U.S. Geological Survey Geologic Quadrangle Map GQ1295, scale 1:24,000.

Mackin, J.H., and Rowley, P.D., 1976, Geologic map of the Three Peaks quadrangle, Iron County, Utah: U.S. Geological Survey Geologic Quadrangle Map GQ-1297, scale $1: 24,000$.

Maldonado, Florian, 1995, Decoupling of mid-Tertiary rocks, Red Hills-western Markagunt Plateau, southwestern Utah, in Geologic studies in the Basin and Range-Colorado Plateau transition in southeastern Nevada, southwestern Utah, and northwestern Arizona, 1992: U.S. Geological Survey Bulletin 2056-I, p. 235-254.

Maldonado, Florian, Sable, E.G., and Nealey, D.D., 1997, Cenozoic low-angle faults, thrust faults, and anastomosing high-angle faults, western Markagunt Plateau, southwestern Utah, in Geologic studies in the Basin and Range-Colorado Plateau transition in southeastern Nevada, southwestern Utah, and northwestern Arizona, 1995: U.S. Geological Survey Bulletin 2153-G, p. 129149.

Mason, J.L., 1998, Ground-water hydrology and simulated effects of development in the Milford Area, an arid basin in southwestern Utah: U.S. Geological Survey Professional Paper 1409-G, 69 p.

Maxey, G.B., and Eakin, T.E., 1949, Ground water in White River Valley, White Pine, Nye, and Lincoln Counties, Nevada: Nevada State Engineer, Water Resources Bulletin $8,59 \mathrm{p}$.

McAda, D.P., and Baroll, Peggy, 2002, Simulation of groundwater flow in the Middle Rio Grande basin between Cochiti and San Acacia, New Mexico: U.S. Geological Survey Water-Resources Investigations Report 02-4200, 81 p.

McDonald, M.G., and Harbaugh, A.W., 1988, A modular threedimensional finite-difference ground-water flow model: U.S. Geological Survey Techniques of Water-Resources Investigations, book 6 , chap. A1, [variously paged].

Meinzer, O.E., 1911, Ground water in Juab, Millard, and Iron Counties, Utah: U.S. Geological Survey Water-Supply Paper No. 277, 162 p.

Michel, R.L., 1989, Tritium deposition over the continental United States, 1953-1983, in Atmospheric Deposition: International Association of Hydrological Sciences, Oxfordshire, United Kingdom, p. 109-115.

Mower, R.W., and Cordova, R.M., 1974, Water resources of the Milford Area, Utah, with emphasis on ground water: Utah Department of Natural Resources Technical Publication No. 43, 106 p.

National Oceanic and Atmospheric Administration, 1951-2000, Climatological data, Annual summaries, Utah: Asheville, North Carolina, v. 53-102.

Nichols, W.D., 2000, Chapter A. Determining ground-water evapotranspiration from phreatophyte shrubs and grasses as a function of plant cover or depth to ground water, Great Basin, Nevada and eastern California, in Regional ground- 


\section{Hydrology and Simulation of Ground-Water Flow in Cedar Valley, Iron County, Utah}

water evapotranspiration and ground-water budgets, Great Basin, Nevada: U.S. Geological Survey Professional Paper 1628, p. A1-A14.

Plummer, L.N., Michel, R.L., Thurman, E.M., and Glynn, P.D., 1993, Environmental tracers for age dating young ground water, in Alley, W.M., ed., Regional Ground-Water Quality: New York, Von Nostrand Reinhold, p. 255-294.

Plummer, L.N, and Busenberg, Eurybiades, 2000, Chlorofluorocarbons, in Cook, P.G., and Herczeg, A.L., eds., Environmental Tracers in Subsurface Hydrology: Boston, Kluwer Academic Publishers, p. 441-478.

Rowley, P.D., 1975, Geologic map of the Enoch NE quadrangle, Iron County, Utah: U.S. Geological Survey Geologic Quadrangle Map GQ-1301, scale 1:24,000.

Rowley, P.D., 1976, Geologic map of the Enoch NW quadrangle, Iron County, Utah: U.S. Geological Survey Geologic Quadrangle Map GQ-1302, scale 1:24,000.

Rowley, P.D., 1998, Cenozoic transverse zones and igneous belts in the Great Basin, western United States: Their tectonic and economic implications, in Faulds, J.E., and Stewart, J.H., eds., Accommodation Zones and Transfer Zones: The Regional Segmentation of the Basin and Range Province: Geological Society of America Special Paper 323, p. 195-228.

Rowley, P.D., and Threet, R.L., 1976, Geologic map of the Enoch quadrangle, Iron County, Utah: U.S. Geological Survey Geologic Quadrangle Map GQ-1296, scale $1: 24,000$.

Rozanski, K., Araguas-Araguas, L., and Gonfiantini, R., 1993, Isotopic patterns in modern global precipitation, in Swart, P.K., Lohmann, K.C., McKenzie, J., and Savin, S., eds., Climate change in continental isotopic records: American Geophysical Union, Geophysical Monograph 78, p. 1-36.

Sandberg, G.W., 1962, Ground-water conditions in the Milford and Beryl-Enterprise Districts and in Cedar City and Parowan Valleys, Utah, 1954-60: U.S. Geological Survey Open-File Report, 84 p. [Located in the files of the U.S. Geological Survey, Salt Lake City, Utah]

Sandberg, G.W., 1963, Ground-water data-Parts of Washington, Iron, Beaver, and Millard Counties, Utah: Utah State Engineer Basic-Data Report No. 6, 26 p.

Sandberg, G.W., 1966, Ground-water resources of selected basins in southwestern Utah: Utah State Engineer Technical Publication No. 13, 46 p.

Sheldon, A., 2002, Diffusion of radiogenic helium in shallow ground water, implications for crustal degassing: $\mathrm{Ph} . \mathrm{D}$. dissertation, University of Utah, $185 \mathrm{p}$.

Silva, S.R., Kendall, C., Wilkison, D.H., Ziegler, A.C., Chang, C.C.Y., and Avanzino, R.J., 2000, A new method for collection of nitrate from fresh water and the analysis of nitrogen and oxygen isotope ratios: Journal of Hydrology, no. 12, p. 22-36.

Solomon, D.K., and Cook, P.G., 2000, ${ }^{3} \mathrm{H}$ and ${ }^{3} \mathrm{He}$, in Cook, P.G., and Herczeg, A.L., eds., Environmental Tracers in Subsurface Hydrology: Boston, Kluwer Academic Publishers, p. 397-424.
Stewart, J.H., Poole, F.G., and Wilson, R.F., 1972a, Stratigraphy and origin of the Chinle Formation and Upper Triassic strata in the Colorado Plateau region: U.S. Geological Survey Professional Paper 690, 336 p.

Stewart, J.H., Poole, F.G., and Wilson, R.F., 1972b, Stratigraphy and origin of the Triassic Moenkopi Formation and related strata in the Colorado Plateau region: U.S. Geological Survey Professional Paper 691, 195 p.

Stute, Martin, and Schlosser, Peter, 2000, Atmospheric noble gases, in Cook, P.G., and Herczeg, A.L., eds., Environmental Tracers in Subsurface Hydrology: Boston, Kluwer Academic Publishers, p. 349-377.

Susong, D.D., 1995, Water budget and simulation of onedimensional unsaturated flow for a flood- and a sprinklerirrigated field near Milford, Utah: Utah Department of Natural Resources Technical Publication No. 109, 32 p.

Thomas, H.E., Nelson, W.B., Lofgren, B.E., and Butler, R.G., 1952, Status of development of selected ground-water basins in Utah: Utah State Engineer Technical Publication No. 7, 96 p.

Thomas, H.E., and Taylor, G.H., 1946, Geology and groundwater resources of Cedar City and Parowan Valleys, Iron County, Utah: U.S. Geological Survey Water-Supply Paper 993, 210 p.

Threet, R.L., 1963, Structure of the Colorado Plateau margin near Cedar City, Utah, in Guidebook to the Geology of Southwestern Utah: Intermountain Association of Petroleum Geologists, p. 104-117.

U.S. Geological Survey, 1964, Water resources data for Utah, 1963, Part 1. Surface water records, 272 p.

U.S. Geological Survey, 1965, Water resources data for Utah, 1964, Part 1. Surface water records, 283 p.

U.S. Geological Survey, 1966, Water resources data for Utah, 1965, Part 1. Surface water records, 315 p.

U.S. Geological Survey, 1967, Water resources data for Utah, 1966, Part 1. Surface water records, 336 p.

Utah Climate Center, 1996, 1961-90 normal precipitation contours: Utah State University, Logan, Utah.

Utah Department of Natural Resources, Division of Water Resources, 1993, A water-related land use inventory report of the Cedar/Beaver Basin, 46 p.

Utah Department of Natural Resources, Division of Water Rights, 2001, Point of Diversion Query Program, accessed November 2001 at http://waterrights.utah.gov/cgibin/wrindex.exe

Utah State University, 1994, Consumptive use of irrigated crops in Utah: Utah Agricultural Experiment Station Research Report 145, 361 p.

Waite, H.A., Nelson, W.B., Lofgren, B.E., Barnell, R.L., and Butler, R.G., 1954, Status of ground-water development in four irrigation districts in southwestern Utah, in Progress report on selected ground-water basins in Utah: Utah State Engineer Technical Publication No. 9, 128 p.

Western Regional Climate Center, Precipitation at Cedar City airport, accessed February 18, 2005, at http://www. wrcc.dri.edu/cgi-bin/cliMAIN.pl?utceda 
White, W.N., 1932, A method of estimating ground-water supplies based on discharge by plants and evaporation from soil-Results of investigations in Escalante Valley, Utah: U.S. Geological Survey Water-Supply Paper 659-A, p.1105.

Wilkowske, C.D., 1998, Chlorofluorocarbons as hydrologic and geochemical tracers in fractured shales and saprolite, Oak Ridge Reservation, Tennessee: MS thesis, University of Utah, $116 \mathrm{p}$.

Williams, V.S., and Maldonado, Florian, 1995, Quaternary geology and tectonics of the Red Hills area of the Basin and Range-Colorado Plateau transition zone, Iron County, Utah, in Geologic studies in the Basin and Range-Colorado Plateau transition in southeastern Nevada, southwestern Utah, and northwestern Arizona, 1992: U.S. Geological Survey Bulletin 2056-J, p. 257-275.

Wilson, G.B., and McNeill, G.W., 1997, Noble gas recharge temperatures and the excess air component: Applied Geochemistry, v. 12, no. 6, p. 747-762.

Wood, W.W., 1999, Use and misuse of the chloride mass-balance method in estimating ground-water recharge: Ground Water, v. 37, no. 1, p. 2-3.

Wood, W.W., and Sanford, W.E., 1995, Chemical and isotope methods for quantifying ground-water recharge in a regional, semiarid environment: Ground Water, v. 33, no. 3, p. $458-468$. 
114 Hydrology and Simulation of Ground-Water Flow in Cedar Valley, Iron County, Utah 


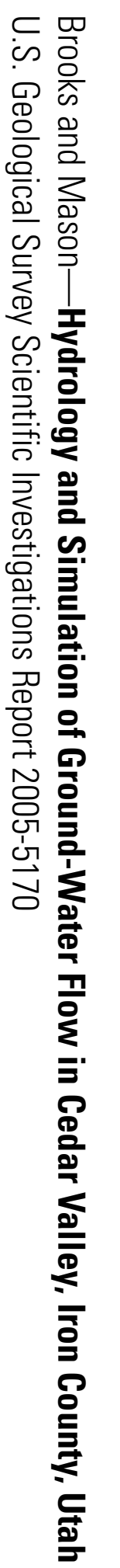

